\title{
The Citizenship Experiment
}




\title{
Studies in the History of Political Thought
}

\author{
Series Editor \\ Annelien de Dijn (Utrecht University)
}

Advisory Board

Janet Coleman (London School of Economics and Political Science, UK)

Vittor Ivo Comparato (University of Perugia, Italy)

Jacques Guilhaumou (CNRS, France)

John Marshall (Johns Hopkins University, Baltimore, USA)

Markku Peltonen (University of Helsinki, Finland)

VOLUME 15

The titles published in this series are listed at brill.com/ship 


\section{The Citizenship Experiment}

Contesting the Limits of Civic Equality and Participation in the Age of Revolutions

By

René Koekkoek

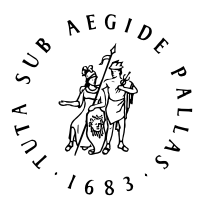

B R I L L

LEIDEN | BOSTON 
This is an open access title distributed under the terms of the CC-BY-NC 4.o license, which permits any non-commercial use, distribution, and reproduction in any medium, provided the original author(s) and source are credited. Further information and the complete license text can be found at https://creativecommons.org/licenses/ by-nc/4.0/

The terms of the CC license apply only to the original material. The use of material from other sources (indicated by a reference) such as diagrams, illustrations, photos and text samples may require further permission from the respective copyright holder.

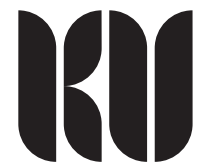

An electronic version of this book is freely available, thanks to the support of libraries working with Knowledge Unlatched. More information about the initiative can be found at www.knowledgeunlatched.org.

Cover illustration: Carel Frederik Bendorp (1736-1814), Allegorie op de Conventie (1795), Rijksmuseum, Amsterdam. For a detailed description: see page ix.

The Library of Congress Cataloging-in-Publication Data is available online at http://catalog.loc.gov LC record available at http://lccn.loc.gov/2019038014

Typeface for the Latin, Greek, and Cyrillic scripts: “Brill”. See and download: brill.com/brill-typeface.

ISSN 1873-6548

ISBN 978-90-04-22570-1 (hardback)

ISBN 978-90-04-41645-1 (e-book)

Copyright 2020 by René Koekkoek. Published by Koninklijke Brill NV, Leiden, The Netherlands. Koninklijke Brill NV incorporates the imprints Brill, Brill Hes \& De Graaf, Brill Nijhoff, Brill Rodopi, Brill Sense, Hotei Publishing, mentis Verlag, Verlag Ferdinand Schöningh and Wilhelm Fink Verlag. All rights reserved. No part of this publication may be reproduced, translated, stored in a retrieval system, or transmitted in any form or by any means, electronic, mechanical, photocopying, recording or otherwise, without prior written permission from the publisher.

Authorization to photocopy items for internal or personal use is granted by Koninklijke Brill NV provided that the appropriate fees are paid directly to The Copyright Clearance Center, 222 Rosewood Drive, Suite 910, Danvers, MA 01923, USA. Fees are subject to change.

This book is printed on acid-free paper and produced in a sustainable manner. 


\section{Contents}

Acknowledgments VII

Cover Illustration IX

\section{Introduction $\quad 1$}

$1 \quad$ Citizenship in the Age of Revolutions $\quad 2$

2 The Terror and the Haitian Revolution 7

3 A Comparative Approach to the 'Atlantic Thermidor' 14

1 'The Kindred Spirit Tie of Congenial Principles' 26

1 Rights Declarations and the Constitutional Framework of Citizenship $\quad 31$

2 Converging Revolutionary Citizenship Ideals 34

3 The French Revolution and the Heyday of a Transatlantic Ideal of Citizenship $\quad 43$

4 Regimes of Exclusion $\quad 5^{2}$

2 Saint-Domingue, Rights and Empire $\quad 57$

1 The Logic of Rights and the Realm of Empire 60

2 The Nation's Colonial Citizens 63

3 Slavery and Civic Inequality in the US before Saint-Domingue $\quad 69$

3 The Civilizational Limits of Citizenship $\quad 78$

1 The Enlightenment Language of Civilization 82

$2 \quad$ Unity and Hierarchy in the French Empire $\quad 91$

3 Levelling Principles and Remorseless Savages $\quad 97$

4 The Turn Away from French Universalism 105

$1 \quad$ Citizenship and Inequality in the Dutch Republican Empire 107

2 'The vile machinations of men calling themselves philosophers' $\quad 118$

3 The French Colonial Thermidor 123

5 Uniting 'good' Citizens in Thermidorian France 132

1 The Revolutionary Political Culture of Citizenship, 1792-1794 136

2 Good Citizen / Bad Citizen 141

$3 \quad$ Isolating the Citizen $\quad 146$

4 What is a Good Citizen? Redefining Civic Virtues 154

$5 \quad$ Narrowing Down Political Citizenship $\quad 158$ 
6 The Post-Revolutionary Contestation and Nationalization of American Citizenship $\quad 169$

$1 \quad$ A Burgeoning Partisan Public Sphere 171

2 'Whether France is Saved or Ruined, is still Problematical'

3 Political Societies, Faction, and the Limits of Democratic Citizenship 179

$4 \quad$ Anti-Jacobinism and the American Citizenship Model $\quad 188$

7 Forging the Batavian Citizen in a Post-Terror Revolution 201

1 Portraying the Terror between Orangist Restoration and Batavian Revolution 205

2 Limiting Power, Protecting Rights: The Terror and the Need for a Constitution 213

3 Channelling the Participation of the People 219

4 Nationalization 227

5 The End of the Democratic-Republican Citizen $\quad 231$

Epilogue: The Age of Revolutions as a Turning Point in the History of Citizenship 240

Bibliography $\quad 253$

Index 290 


\section{Acknowledgments}

This book project began at Utrecht University's Research Institute for History and Culture and was generously financed by a grant from the Netherlands Organization for Scientific Research (NWO). I am most grateful for their financial and institutional support. It is also a great pleasure to thank my supervisors Ido de Haan and Wijnand Mijnhardt. Ido has been my mentor since I started my research master in history in Utrecht in 2008. His rigour and demanding standards have sharpened this book's arguments as well as my attitude of mind in general. At an early stage, Wijnand agreed to act as a second supervisor. I deeply appreciated his eye for the big picture and his infectious enthusiasm for scholarship in the true sense of the word. I also wish to thank Maarten Prak for his help in the earliest stages of my research project. During the final stages of my research I had the privilege to spend time at Princeton University where David Bell welcomed me as a graduate research fellow. I profited greatly from his incisive comments and was honoured that I was given the opportunity to present my project at the distinguished Princeton Eighteenth Century Seminar. I want to thank him also for staying in touch and sharing his advice with me long after I had left New Jersey.

The seeds for this project were sown during my studies at the bachelor's and master's level. In particular James Kennedy, Josine Blok and Siep Stuurman have shaped my thinking. I owe a special thanks to Wyger Velema who -in his research seminar on the Batavian Revolution- ignited my interest in the late eighteenth-century Age of Revolutions.

I presented research papers related to the book project at several venues: the International Congress for Eighteenth Century Studies in Rotterdam, the Third International Conference of the Association for Political History at Bielefeld University, the Conference The Roots of Nationalism, 1600-1815 at Nijmegen University, the Seminar of the Research School Political History at Utrecht, the International Conference on the History of Concepts in Bilbao, the Annual Weissbourd Conference of the Society of Fellows at University of Chicago, and the Consortium of the Revolutionary Era, in Charleston, S.C. I thank all the audiences for their questions and comments. In particular, I benefited from comments by, and conversations with Hans Erich Bödeker, Samuel Moyn, and Henk te Velde. A special thanks also to Katlyn Carter and James Alexander Dun for collaborating on a panel at the Consortium and for exchanging insights on the revolutionary era in both Princeton and Charleston. In addition, thanks to Nathan Perl-Rosenthal for sharing his thoughts with me through e-mail on the concept of citizenship in the revolutionary era. 
At Utrecht University as well as the University of Amsterdam I have benefited greatly from comments and suggestions by Pepijn Corduwener, Joris Oddens, Jan Rotmans, Devin Vartija, and Bart Verheijen. Over the last years I have also greatly appreciated the academic companionship and collaboration on various exciting projects with: Lars Behrisch, Camille Creyghton, Annelien de Dijn, Boyd van Dijk, Lisa Kattenberg, and Matthijs Lok, and again Devin and Pepijn.

I want to thank the series editor Annelien de Dijn for enthusiastically welcoming my book in the Brill Series in the History of Political Thought. Thanks to my editor Ivo Romein and production editor Kim Fiona Plas for the smooth and pleasant collaboration, and the three anonymous reviewers for their comments.

I also want to thank a number of people without whom this book would not have been possible. First of all, my mother Ann Schilderinck and father Flip Koekkoek for their encouragement and support. Unfortunately, my father was only able to witness my first years as a history student. I want to thank Bert Leufkens who together with Ann has meant a lot for me and my family. Many thanks to my mother-in-law, Marjet Vos, who has been a mainstay for our family; and thanks also to my father-in-law Gerard Bakker in whose home at the lake of Vinkeveen I wrote many pages that ended up in this book. It was very important to me, Fedja and my children to have my sister Sanneke Koekkoek and brother-in-law Joost Lemmens and their children living close to us during the years of research and writing.

Finally, I want to thank Fedja for everything. She has witnessed - and probably suffered most from - every stage of the project. In the meanwhile, we've been incredibly lucky and thankful to have welcomed our three wonderful children: Cosima, Clovis, and Mazarine. Sometimes I don't quite know how we do it, but your love, humor, and unconditional support make it all worthwhile. 


\section{Cover Illustration}

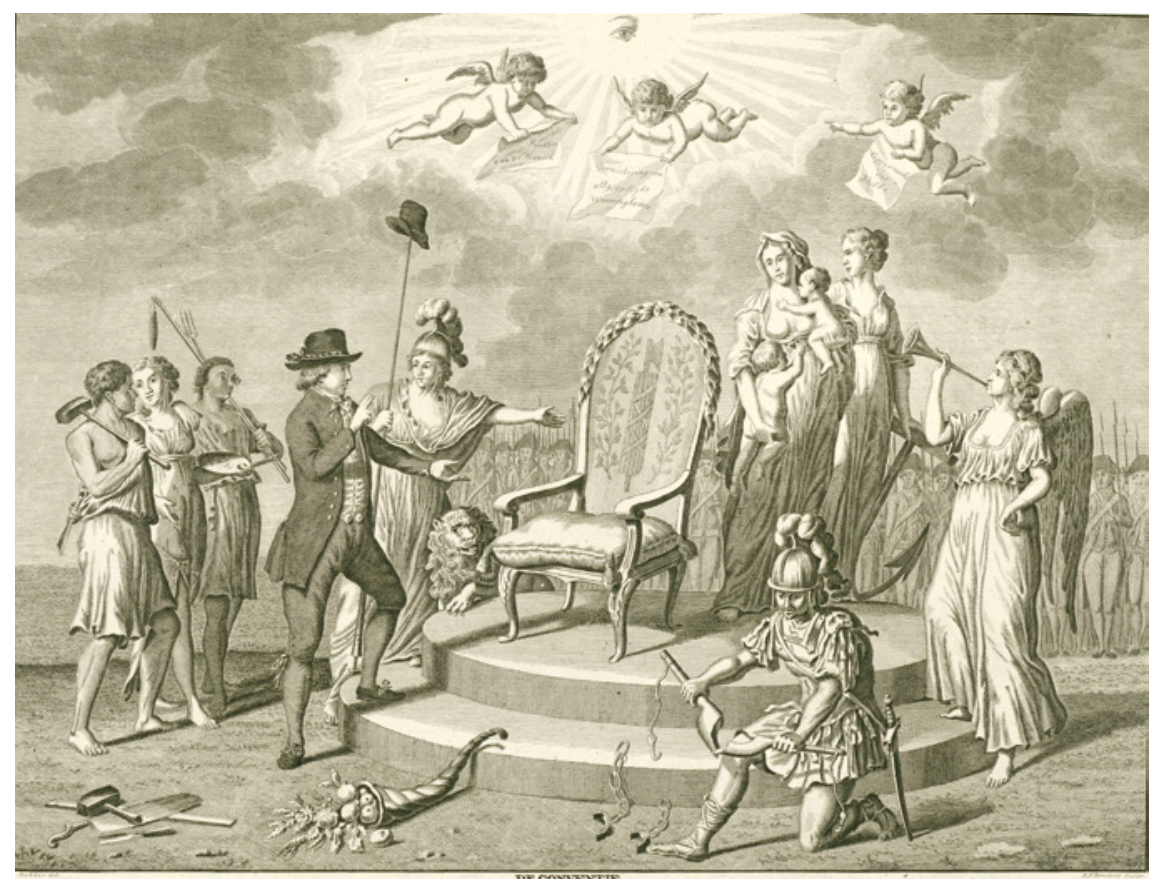

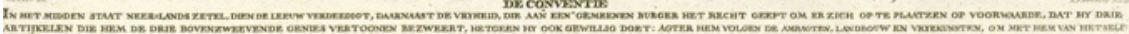

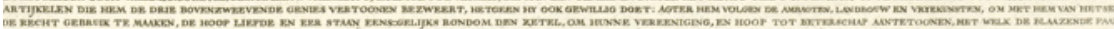

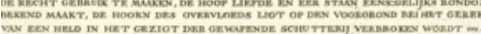

Carel Frederik Bendorp (1736-1814), Allegory of the Convention (original: Allegorie op de Conventie) (1795), Rijksmuseum, Amsterdam.

\section{Text}

In het midden staat Neer-lands zetel, dien de leeuw verdeedigt, daarnaast de vryheid die aan een' gemeenen burger het recht geeft om er zich op te plaatzen op voorwaarde, dat hy drie artijkelen die hem de drie bovenzweevende genies vertoonen bezweert ['Rechten van den Mensch'; 'Vernietiging van alle erflijke Waardigheden'; 'Oppermacht des volks'], hetgeen hy ook gewillig doet: agter hem volgen de ambagten, landbouw en vryekunsten, om met hem van het hetselfde recht gebruik te maaken, de hoop liefde en eer staan eens-gelijks rondom den zetel, om hunne vereeniging, en hoop tot beterschap aantetoonen, het welk de blaazende faam bekend maakt, de hoorn des overvloeds ligt op den voorgrond bei het gereedschap der handwerklieden, als een gevolg dezer gebeurenisse; terwijl het juk door den sterken arm van een held in het gezigt der gewapende schutterij verbroken wordt enz. 


\section{Translation}

In the middle stands the Netherlands's seat, protected by the Lion, next to it Liberty who grants the common citizen the right to settle down, on the condition that he swears to the three articles presented by the winged guardianangels ['Rights of Man'; 'Destruction of all Hereditary Titles'; 'Sovereignty of the People'], which he willingly does: behind the Trades, Agriculture, and the Liberal Arts follow him in claiming the same right; Hope, Love, and Honour stand united around the seat in order to demonstrate their union and hope for improvement, which is announced by the Trump of Fame; the Horn of Plenty lies on the foreground next to the artisan's tools, as a consequence of these events; while the yoke is being broken by the strong arm of a hero in sight of the armed citizen's militia, etc. 


\section{Introduction}

This is a book about the fate of the ideal of citizenship in the Age of Revolutions. It examines how over the course of the 1790s Americans, Frenchmen, and Dutchmen articulated and debated their ideas and ideals of citizenship in light of the Haitian Revolution (1791-1804) and the French revolutionary Terror (1793-1794). It argues that the uprisings of free coloured people and black slaves in Saint-Domingue and the Terror in continental France became transnationally shared points of reference and sites of contemplation. They turned into phenomena that bred anxieties and raised difficult questions about the nature and limits of two core ideals of the revolutionary citizenship discourse of the Age of Atlantic Revolutions: civic equality and political participation. The momentous and, to many, shocking events that reverberated throughout the Atlantic world coloured events at home, informed a range of arguments in domestic political debates, and generated parallel patterns in the evaluation of the limits and dangers of revolutionary citizenship. By the end of the 179os, the intellectual repercussions of these experiences shattered the ideological unity of an Atlantic revolutionary movement - and moment. It led Americans, Frenchmen, and Dutchmen to abandon the notion of a shared, Atlantic, revolutionary vision of citizenship and to forge more nationalized conceptions of what it means to be a citizen.

In two important ways, this is a different story than is usually told about the age of revolutions as a turning point in the history of citizenship. First, the legacy of the age of revolutions for the meaning of citizenship is often told in terms of rights-based constitutionalism, the nation-state, representative democracy, and political participation. The 179os, however, were also a breeding ground for a set of arguments for limited citizen participation in politics, for a sustained critique of factional popular societies and the dangers they were seen to represent; for arguments in favour of an exclusive regime of (imperial) citizenship based on civilizational inequality, and for arguments in favour of the idea that nation-states should follow their own path in devising their citizenship arrangements and models. These sets of arguments have long shaped debates about the idea and ideal of citizenship. Importantly, they were not only put forth by reactionary and counter-revolutionary conservatives, but by a cohort of moderate revolutionary and post-revolutionary politicians, journalists, thinkers, and publicists who gave shape to what I call the 'Atlantic Thermidor.'1

1 I wish to thank James Alexander Dun for suggesting this term and discussing it with me.

(C) RENÉ KOEKKOEK, 2020 | DOI:10.1163/9789004416451_002

This is an open access chapter distributed under the terms of the CC BY-NC 4.olicenense. 
Secondly, The Citizenship Experiment aims to overcome the static picture of either the era's ideological and conceptual unity - or, alternatively, its essential plurality. Instead, I propose that the history of what many at the time recognized as a transatlantic political discourse can best be narrated in terms of moments of convergence and moments of divergence. The Atlantic revolutionary moment of the 1790 s was only a short-lived transnational episode of intellectual interaction between largely separate national communication communities. The evolving interaction between 'national' political contestation, on the one hand, and a transnational, intellectual-political horizon, on the other hand, was unstable. The emergence and disintegration of a shared revolutionary citizenship discourse was not a clash of fixed principles, but an evolving process beset with contingencies and events that prompted contemporaries to differentiate between models of citizenship and envision different outcomes.

In pre-revolutionary times, citizenship was primarily understood as a legal and socioeconomic status within the walls of the city. In France and the British American colonies it was overshadowed by the notion of 'subject' who was only granted a limited set of rights. ${ }^{2}$ Over the course of the eighteenth century, however, political thinkers, philosophers, publicists, journalists, as well as lawyers, administrators, and even magistrates of the French parlements (royal sovereign courts), began to employ the notion of citizen more frequently, pushing it in new directions and investing it with new meanings and ideals. ${ }^{3}$ Some of these conceptions of citizenship, as has been well documented, harked back to moral and republican ideals derived from classical times. ${ }^{4}$ Others were

2 J.H. Kettner, The Development of American Citizenship, 1608-1870 (Chapel Hill, N.C.: University of North Carolina Press, 1978); M. Prak, 'Burghers into Citizens: Urban and National Citizenship in the Netherlands during the Revolutionary Era (c.180o)', in: M. Hanagan and C. Tilly (eds.) Extending Citizenship, Reconfiguring States (Lanham, MD: Rowman \& Littlefield 1999), pp. 17-35; P. Sahlins, Unnaturally French: Foreign Citizens in the Old Regime and After (Ithaca, N.Y.: Cornell University Press, 2004).

3 D.A. Bell, Lawyers and Citizens. The Making of a Political Elite in Old Regime France (Oxford: Oxford University Press, 1994); J. Merrick, 'Subjects and Citizens in the Remonstrances of the Parlement of Paris in the Eighteenth Century', Journal of the History of Ideas $5^{1}$ (1990), pp. 453-46o; P. Rétat, 'Citoyen-sujet, civisme', in: R. Reichardt and E. Schmitt (eds.) Handbuch politisch-soziale Grundbegriffe in Frankreich 1680-1820, 8 vols. (Munich: Oldenbourg Verlag, 1988), vol. 8, pp. 75-105; J.J. Kloek and W.W. Mijnhardt, 180o. Blueprints for a National Community (Basingstoke: Palgrave Macmillan, 2005).

4 For the American colonies, see J.G.A. Pocock, The Machiavellian Moment: Florentine Political Thought and the Atlantic Republican Tradition (Princeton, N.J.: Princeton University Press, 
intimately bound up with eighteenth-century social, cultural, and economic processes - and the intense (theoretical) reflection upon these processes: the rise of commercial society and its corresponding public ethics, the growing availability of consumer and luxury goods, the ongoing specialization and division of labour, and new regimes of taxation. ${ }^{5}$ In addition, citizenship was invested with new meanings related to the rise of the public sphere, enlightened sociability in various kinds of 'societies' (sociétés/genootschappen), and the self-reflexive ways in which Americans, Frenchmen, and Dutchmen came to understand 'society' (or 'civil society'/'burgermaatschappij') in historical and comparative socio-anthropological perspective. ${ }^{6}$

2003 [1975]); C. Robbins, The Eighteenth-Century Commonwealthman: Studies in the Transmission, Development, and Circumstance of English Liberal Thought from the Restoration of Charles II until the War with the Thirteen Colonies (Cambridge, MA: Harvard University Press, 1959); G. Wood, The Creation of the American Republic, 1776-1787 (Chapel Hill, N.C.: University of North Carolina Press, 1969). For the Dutch Republic, see W.R.E. Velema, Republicans: Essays on Eighteenth-Century Dutch Political Thought (Leiden: Brill, 2007); S.R.E. Klein, Patriots republikanisme. Politieke cultuur in Nederland (1766-1787) (Amsterdam: Amsterdam University Press, 1995). For France, see K.M. Baker, 'Transformations of Classical Republicanism in Eighteenth-Century France', Journal of Modern History 73 (2001), pp. 32-53, as well as several essays in Inventing the French Revolution. Essays on French Political Culture in the Eighteenth Century (Cambridge: Cambridge University Press, 1990); H. van Effenterre, 'La cité grecque, modèle de République des Républicains', and C. Nicolet, 'Citoyenneté française et citoyenneté romaine, essai de mise en perspective', both in: S. Bernstein and O. Rudelle (eds.) Le modèle républicain (Paris: Presses universitaires de France, 1992), pp. 13-56; R. Monnier, Républicanisme, patriotisme et Révolution française (Paris: L'Harmattan, 2005); J.K. Wright, A Classical Republican in Eighteenth-Century France. The Political Thought of Mably (Stanford, CA: Stanford University Press, 1997).

5 The literature on these topics is extensive, but see T.H. Breen, The Marketplace of Revolution: How Consumer Politics shaped American Independence (Oxford: Oxford University Press, 2004); I. Hont, 'The Early Enlightenment Debate on Commerce and Luxury', in: M. Goldie and R. Wokler (eds.), The Cambridge History of Eighteenth-Century Political Thought (Cambridge: Cambridge University Press, 2006), pp. 379-418; J. Shovlin, The Political Economy of Virtue. Luxury, Patriotism, and the Origins of the French Revolution (Ithaca, N.Y.: Cornell University Press, 2007); M. Sonenscher, Before the Deluge: Public Debt, Inequality and the Intellectual Origins of the French Revolution (Princeton, N.J.: Princeton University Press, 2007). On tax regimes, M. Kwass, Privilege and the Politics of Taxation in Eighteenth-Century France: liberté, égalité, fiscalité (Cambridge: Cambridge University Press, 2000).

6 On the public sphere, see J. van Horn Melton, The Rise of the Public in Enlightenment Europe (Cambridge University Press, 2001) and H. Barker and S. Burrows (eds.) Press, Politics and the Public Sphere in Europe and North America, 1760-1820 (Cambridge: Cambridge University Press, 2002), and classically, J. Habermas, The Structural Transformation of the Public Sphere. An Inquiry into a Category of Bourgeois Society, trans. T. Burger (Cambridge, MA: Polity Press, 1989 [1962]). On sociability, R. Chartier, The Cultural Origins of the French Revolution, trans. L.G. Cochrane (Durham, N.C.: Duke University Press, 1991); D. Goodman, The Republic of Letters: A Cultural History of the French Enlightenment (Ithaca, N.Y.: Cornell University Press, 1994); D. Gordon, Citizens without Sovereignty: Equality and Sociability in French Thought, 
Over the course of the eighteenth century, then, both in theory and practice, citizenship burst out of its urban, legal, and socioeconomic mould. But it was only in the last quarter of the eighteenth century, during what Thomas Paine dubbed the 'age of revolutions', that the concept of citizen acquired unprecedented national and political meanings. A particularly striking aspect of this revolutionary era was that many American, French, and Dutch politicians, journalists, political thinkers, and publicists who contributed to the conceptual transformation of citizenship recognized that their ideas and ideals of citizenship broadly overlapped with each other. At moments, they felt that they spoke a similar 'language', that they were part of a larger transatlantic movement. Generally, they agreed citizenship was to be a constitutionally protected, if still exclusive, status based on the principle of individuality and the universalistic notion of the equal 'rights of man'; citizens, moreover, were to be regarded as members of a nation - it was now possible to speak of American, Dutch, and French citizens; the citizen was the principal carrier of popular sovereignty, and citizens have the right and responsibility to share in some form of democratic self-governance and publicly participate as equals in the determination of a common good on a national scale.

1670-1789 (Princeton, N.J.: Princeton University Press, 1994); R. Halevi, Les Loges maçonniques dans la France d'Ancien régime. Aux origines de la sociabilité démocratique (Paris: Armand Colin, 1984); S.D. Kale, French Salons, High Society and Political Sociability from the Old Regime to the Revolution of 1848 (Baltimore, MD: Johns Hopkins University Press, 2004); D. Roche, Le siècle des lumières en province. Académies et académiciens provinciaux, 1689-1789, 2 vols. (Paris: Mouton, 1978); idem, La France des lumières (Paris: Fayard, 1993); A. Lilti, The World of the Salons. Sociability and Wordliness in Eighteenth-Century Paris, trans. L.G. Cochrane (Oxford: Oxford University Press, 2015). On societies, sociability and the public sphere in the Dutch Republic, see W.W. Mijnhardt, Tot Heil van 't Menschdom. Culturele genootschappen in Nederland, 1750-1815 (Amsterdam: Rodopi, 1988); Kloek and Mijnhardt, 180o; N.C.F. van Sas, De metamorfose van Nederland. Van oude orde naar moderniteit, 1750-190o (Amsterdam University Press, Amsterdam, 2004). On British colonial America and the early American Republic, see J.L. Brooke, 'Consent, Civil Society, and the Public Sphere in the Age of Revolution and the Early American Republic', in: J.L. Pasley, A.W. Robertson, and D. Waldstreicher (eds.), Beyond the Founders: New Approaches to the Political History of the Early American Republic (Chapel Hill, N.C.: University of North Carolina Press, 2004), pp. 207-250; N.C. Landsman, From Colonials to Provincials. American Thought and Culture 1680-1760 (Ithaca, N.Y.: Cornell University Press, 1997); D.S. Shields, Civil Tongues and Polite Letters in British America (Chapel Hill, N.C.: The University of North Carolina Press, 1997). On the theoretical reflection on the emergence of civil society in historical and comparative perspective, see C. Fox, R. Porter, and R. Wokler (eds.), Inventing Human Science. Eighteenth-Century Domains (Berkeley, CA: University of California Press, 1995); D.A. Harvey, The French Enlightenment and its Others. The Mandarin, the Savage, and the Invention of the Human Sciences (Basingstoke: Palgrave Macmillan, 2012); R.L. Meek, Social Science and the Ignoble Savage (Cambridge: Cambridge University Press, 1976); F.G. Whelan, Enlightenment Political Thought and Non-Western Societies: Sultans and Savages (New York: Routledge, 2009). 
Citizenship hence became a multilayered concept informed by, and embedded in, a variety of both political languages and (institutional) practices. ${ }^{7}$ In the second half of the eighteenth century these languages and practices themselves had been very much in flux; even more so during the turbulent 179os. It makes no sense, therefore, to look for one 'definition' of citizenship for this period. As Nietzsche remarked, 'definierbar is nur das, was keine Geschichte hat' ('only that which has no history can be defined'). ${ }^{8}$ In fact, the new meanings ascribed to citizenship and its conceptual innovations as such were contested. The historical actors I discuss in this book were trying to 'fix the public meaning' of citizenship and competing with each other in doing so. ${ }^{9}$

During the 1790 s, the term citizen was also used as a rhetorical instrument, a 'Kampfbegriff. To use the word citizen, was to make a polemical point. ${ }^{10} \mathrm{Il}-$ lustrative is that in all three countries the term citizen became widely propagated and embraced as title, that is, as form of address. ${ }^{11}$ Those who addressed each other accordingly - in American democratic-republican societies, in French Jacobin clubs, in the Dutch Batavian Assembly - not only tried to describe a new socio-political reality, but also to produce one. ${ }^{12}$ This linguistic battle' was both integral part and constitutive of the processes of political

For a wideranging history of urban citizenship in global-comparative perspective see M. Prak, Citizens Without Nations. Urban Citizenship in Europe and the World, c. 1000-1789 (Cambridge: Cambridge University Press, 2018). Prak focuses more on citizenship practices and less on the contestation of egalitarian and participatory citizenship ideals during the age of revolutions.

8 F. Nietzsche, Zur Genealogie der Moral, in: Sämtliche Werke. Kritische Studienausgabe, ed. G. Collini and M. Montinari, 15 vols. (Munich: Deutscher Taschenbuch Verlag, 1980), vol. 5, p. 245 .

9 This way of putting it is Keith Michael Baker's. Baker, Inventing the French Revolution, p. 7 .

10 R. Koselleck, 'Begriffsgeschichte und Sozialgeschichte', in: Idem, Vergangene Zukunft. Zur Semantik geschichtlicher Zeiten (Frankfurt am Main: Suhrkamp Verlag, 1979), pp. 107-129, esp. pp. 111-113. Cf. Q. Skinner, 'Retrospect: Studying rhetoric and conceptual change', in: Q. Skinner, Visions of Politics, 3 vols. (Cambridge: Cambridge University Press, 2002), vol. 1: Regarding Method, pp. 175-187, at p. 177: 'Koselleck and I both assume that we need to treat our normative concepts less as statements about the world than as tools and weapons of ideological debate'.

11 P. McPhee, The French Revolution, 1789-1799 (Oxford: Oxford University Press, 2001), p. 95; B. Baczko, 'Ici on s'honore du titre du citoyen', in: Monnier (ed.), Citoyen et citoyenneté sous la Révolution française, pp. 9-21, at p. 19. The form of address in the Batavian National Assembly was 'Burger representant' (Citizen representative). Citizen was also adopted as form of address in many American democratic-republican societies in the mid-1790s. See A. Koschnik, 'The Democratic Societies of Philadelphia and the Limits of the American Public Sphere, circa 1793-1795', The William and Mary Quarterly $5^{8}$ (2001), pp. 615-636, at p. 621; M. Rutjes, Door gelijkheid gegrepen. Democratie, burgerschap en staat in Nederland 1795-1801 (Nijmegen: Vantilt, 2012), p. 121.

12 Cf. L. Hunt, Politics, Culture, and Class in the French Revolution (Berkeley, CA: University of California Press, 1984), p. 24: '[P]olitical language did not simply reflect the realities of 
conflict and regime change. Identifying oneself or others as 'citizen' signalled loyalty to the new regime. With the dawn of the new era, a citizen came to be sharply distinguished from a (royal) 'subject' and was incessantly put in opposition to the 'aristocrat', the supreme 'counter concept' of citizen..$^{13}$ Citizenship, in short, became a central component of larger ideological visions, as it was intimately linked to other foundational concepts such as rights, constitution, and nation. The ideals associated with citizenship expressed a promise, it became a future-oriented concept. Citizenship was not only an idea informed by traditions and practices from the past, it also expressed an ideal about a society yet to come. ${ }^{14}$

This account of the age of Atlantic revolutions as a turning point in the history of citizenship, that is, of the overlapping revolutionary inventions of what is often called 'modern' citizenship, is well known. ${ }^{15}$ It is, however, also partial.

revolutionary changes and conflicts, but rather was itself transformed into an instrument of political and social change'.

13 The opposition between citizen and aristocrat or nobleman found its paramount expression in Sieyès's 1789 pamphlet Qu'est-ce que le tiers état? See also Rétat, 'Citoyen-sujet, civisme'. For 'counter concept' (Gegenbegriff), R. Koselleck, 'Richtlinien für das "Lexikon Politisch-sozialer Begriffe der Neuzeit"', Archiv für Begriffsgeschichte 11 (1967), pp. 81-99.

14 Koselleck, Vergangene Zukunft.

15 See, for instance, R. Bellamy, Citizenship. A Very Short Introduction (Oxford: Oxford University Press, 2008), pp. 42-43; D. Heater, A Brief History of Citizenship (New York: New York University Press, 2004), pp. 65-87; A. Fahrmeir, Citizenship. The Rise and Fall of a Modern Concept (New Haven, CT: Yale University Press, 2007), 27-55; M. Riedel, 'Bürger, Staatsbürger, Bürgertum', in: O. Brunner, W. Conze and R. Koselleck (eds.) Geschichtliche Grundbegriffe. Historisches Lexikon zur politischen-sozialen Sprache in Deutschland, 8 vols. (Stuttgart: Klett-Cotta, 1974-1997), vol. 2, pp. 672-725; P. Riesenberg, Citizenship in the Western Tradition: Plato to Rousseau (Chapel Hill, N.C.: University of North Carolina Press, 1992). For French citizenship, see R. Brubaker, 'The French Revolution and the Invention of Citizenship', French Politics and Society 7 (1989), pp. 30-49; R. Monnier (ed.), Citoyen et citoyenneté sous la Révolution française (Paris: Société des études robespierristes, 2006); Rétat, 'Citoyen-sujet, civisme'; P. Rosanvallon, Le sacre du citoyen. Histoire intellectuelle du suffrage universel en France (Paris: Gallimard, 1992); W.H. Sewell, 'Le Citoyen, la Citoyenne: Activity, Passivity and the French Revolutionary Concept of Citizenship', in: C. Lucas (ed.) The French Revolution and the Creation of Modern Political Culture, vol. 2: Political Culture of the French Revolution (Oxford: Pergamon Press, 1988), pp. 105-125; R. Waldinger, P. Dawson, and I. Woloch, (eds.) The French Revolution and the Meaning of Citizenship (Westport, CT: Greenwood Press, 1993). For the American case, see D. Bradburn, The Citizenship Revolution: Politics and the Creation of the American Union 1774-1804 (Charlottesville, VA: University of Virginia Press, 2009); Kettner, The Development of American Citizenship. For the conceptual development of Dutch citizenship in the revolutionary era, see Rutjes, Door gelijkheid gegrepen; Van Sas, De metamorfose van Nederland; Velema, Republicans. For the notion of 'modern' republics, see B. Fontana (ed.), The Invention of 
For during the 179os this Atlantic family of overlapping conceptions of citizenship was put into question on virtually all accounts. The Haitian Revolution and the Terror posed fundamental challenges to the scope, political nature, and perceived commonality of transatlantic visions of citizenship. The major uprising of black slaves and free men of colour in the French plantation colony Saint-Domingue and the interaction between metropolitan France and her colony's inhabitants - in particular the hundreds of thousands of black slaves raised fundamental questions about the universality and scope of citizenship, as well as, crucially, the appropriate framework of citizenship. If the different parts of the French and Dutch colonial empires were part of the new 'nationstate', who within this empire was eligible to become citizen? Who constituted the nation? To whom did one of the cardinal underlying principles of citizenship - the rights of man - actually apply? ${ }^{16}$

At around the same time, the political violence perpetrated under the radicalized Jacobin republic in France between 1793 and 1794 forced many observers and commentators throughout the Atlantic to reflect anew on the democratic-republican ideal of citizenship and the desirability of a broad politically involved citizenry. Based on their reactions to, and reflections on, these two crucial historical events in the age of revolutions, many Americans, Dutchmen, and Frenchmen started to reassess the commonalities and differences between their revolutionary conceptions of citizenship and their underlying principles. Soon after the revolutionary concepts and ideals of citizenship were expressed in an unprecedented universalistic and politicized language that many thought was shared on both sides of the Atlantic, they were immediately put to the test - in what some, quite literally, described as an 'experiment'.

The Citizenship Experiment weaves together three stories that are usually told separately: the convergence and divergence of a transatlantic revolutionary political discourse; the (re)evaluation of the key concept of citizenship; and the discursive repercussions of the French Revolutionary Terror and the

the Modern Republic (Cambridge: Cambridge University Press, 1994); A. Kalyvas and I. Katznelson, Liberal Beginnings. Making a Republic for the Moderns (Cambridge: Cambridge University Press, 2008).

16 For a recent discussion of citizenship as a form of 'claim-making' in imperial contexts, see F. Cooper, Citizenship, Inequality, and Difference (Princeton, N.J.: Princeton University Press, 2018). 
Haitian Revolution. The public representation and contestation of the Haitian Revolution and the Terror serve as lenses to zoom in on key moments in revolutionary debates about the scope and meaning of citizenship. Why these events and why discuss them in tandem? There were, after all, other important political events, conditions, and practices that informed and shaped ideas and definitions of citizenship. War and occupation, education and civic festivals, religion and church-state relations without doubt left their marks on the new meanings citizenship took on in the age of revolutions. ${ }^{17}$ Yet only the French revolutionary Terror and the Haitian Revolution would become elements in an Atlantic framework of reference, transcending the boundaries of the nationstate and constituting a shared political-conceptual horizon in such a way that they incited more general reflections pertaining to debates about citizenship at home.

The historical actors examined in this book did not conceive of the events taking place in the French Caribbean and continental France as 'the Haitian Revolution' or 'the Terror'.18 Regarding the latter, they did not carry the load - or burden - of two centuries of politicized historiographical contestation of the Terror. This is of course not to say that interpretations of the Terror in the $1790 \mathrm{~s}$ were not coloured, on the contrary. Contemporaries often lacked accurate and detailed information on what had happened as well as an overview of the facts. They did not know that the French Republic would be succeeded by an authoritarian dictatorship; they did not interpret the Terror in the shadow of twentieth-century totalitarianism. Analysing reflections on 'the Terror' in different national contexts, then, in the first place means examining responses to anarchic and popular violence, as well as radical and disruptive political change in the context of war and counterrevolutionary forces, and subsequently situating these reactions in the respective contexts of national political struggles and public debates in which they appeared.

17 Annie Crépin, 'The Army of the Republic: New Warfare and a New Army', in: P. Serna, A. de Francesco, and J. Miller (eds.), Republics at War, 1776-1840. Revolutions, Conflicts, and Geopolitics in Europe and the Atlantic World (Basingstoke: Palgrave MacMillan, 2013), pp.131-148;J.Osman, CitizenSoldiers and the KeytotheBastille(London:Palgrave Macmillan, 2015).

18 Cf. M. Trouillot, Silencing the Past. Power and the Production of History (Boston, MA: Beacon Press, 1995); A. Jourdan, 'Les discours de la terreur à l'époque révolutionnaire (17761798): Etude comparative sur une notion ambiguë', French Historical Studies 36 (2013), pp. 51-81. In fact, there is a growing scholarly consensus that there was no systematic, ideologically-driven Terror. See D. Andress, The Terror. Civil War in the French Revolution (London: Little, Brown, 2005); P. Gueniffey, La politique de la Terreur. Essai sur la violence révolutionnaire (Paris: Fayard 200o); Jean-Clément Martin, Violence et Révolution. Essai sur la naissance d'un mythe national (Paris: Seuil, 2006); T. Tackett, The Coming of the Terror in the French Revolution (Cambridge, MA: Harvard University Press, 2015). 
Likewise, the succession of events on Saint-Domingue were not only interpreted in registers and frameworks of reference other than ours, they also varied and evolved over time, precisely because the succession of events was so dramatic and quick. Contemporaries of the Haitian Revolution did not see a 'Haitian Revolution'.19 News reports, letters, oral communications, as well as interpretations of events contained in journal and newspaper articles, pamphlets, and so forth, of what happened in France and Saint-Domingue were incomplete, partial, coloured, and surrounded by rumours, and misinformation. What aspects of the Haitian Revolution were singled out and commented upon, and at what moments, differed from country to country.

The interpretations and representations of the Haitian Revolution and the Terror, their nature and their causes, then, were often the products of conscious intellectual and political manoeuvring conditioned by the specific (Dutch, French, or American) context in question. The different intellectual and institutional traditions of citizenship, the varying revolutionary or postrevolutionary phases in which American, Dutch, and French commentators were struggling, and hence the different political agenda's they pursued, must all be taken into account in order to explain the differences in emphasis, timing, intensity, and consequences of these processes of rethinking citizenship ideals. References to, and evaluations of, the Terror as well as the question of what lessons might be learned from them, became devices in rhetorical toolkits that functioned in arguments deployed in distinct political and intellectual disputes. This book, then, does not aspire to make a contribution to the rich and ever-growing historiography of these events as such. The conceptualization of these 'traumatic' events rather serves as a prism through which I examine the ways in which the ideals of citizenship were evaluated and articulated.

This study starts from the premise that we first need to gain insight into these messy processes of representation, interpretation, and public opinion formation in order to understand how these interpretations and representations were formed and integrated in the rhetoric and arguments about what it means to be - and who is eligible to become - a citizen.

These methodological choices are reflected in my selection of sources. They include newspapers, journals, (printed) speeches, (minutes of) parliamentary debates, political tractates, pamphlets, and (some) letters. Although

19 Cf. J.A. Dun, Dangerous Neighbors. Making the Haitian Revolution in Early America (Philadelphia, PA: University of Pennsylvania Press, 2016), pp. 21, 90-91: 'Americans saw a French Revolution in Saint Domingue, not a Dominguan (let alone Haitian) Revolution'. 
the Americans, Frenchmen, and Dutchmen of the 1790s shared an Atlantic framework of reference, the reactions to the Terror and the Haitian Revolution variated widely. Some merely found confirmation of their beliefs that there was something fundamentally wrong with the principles underlying revolutionary citizenship as such. Others believed that these principles only applied to a limited group, and drew, sometimes eagerly so, on the examples of Saint-Domingue and revolutionary France to make their point. Still others saw the popular violence and anarchy of the Haitian Revolution and the Terror as aberrations that were quite understandable and could be explained (away). My historical reconstruction seeks to do justice to this range of positions taken in these debates.

The ideological backlash against the radicalization of the French Revolution, and the Terror in particular, has of course not escaped the attention of scholars of the Age of Revolutions. The notions, furthermore, that political citizenship should be restricted to certain categories of people and that someone requires a certain level of enlightenment (or education) to assume the duties of political citizenship, long predate the revolutionary 179os. What is less well understood is that the restrictions placed on citizenship happened within the broader context of a retrenchment of an Atlantic political imagination. This book therefore focuses on those who interpreted the convulsive episodes in revolutionary France and Saint-Domingue as fracturing a common revolutionary citizenship discourse. The Americans and Dutchmen who play an important role in my account, held, or gradually came to hold that the radical 'French' conception of citizenship was particularly dangerous and irresponsibly universalistic. They sought to disassociate their nationalized 'American' or 'Dutch' models of citizenship from the French one. Within France, the post-Terror group of politicians often referred to as the Thermidorian centre too came to reject the more radical conceptions of equality and direct political participation under the Jacobin regime. The term 'Thermidorian' here refers to the date of the fall of Robespierre on 9 Thermidor Year II according to the French revolutionary calendar (July 27, 1794). The 'Thermidorian regime' thus designates the regime that ruled from late July until October 26, 1795 . More broadly, the Thermidorian moment has come to be seen as a dividing line in the revolutionary experience, as well as a 'mirror': after a period of permanent revolutionary action and excesses came a moment of reflection and reaction. The (imagined) unity of the French revolutionary experience was broken. ${ }^{20}$ During

20 B. Baczko, Ending the Terror: The French Revolution after Robespierre, trans. M. Petheram (Cambridge: Cambridge University Press, 1994); S. Luzzatto, L'automne de la Révolution. Luttes et cultures politiques dans la France thermidorienne, trans. S.C. Messina (Paris: Editions Honoré Champion, 2001). 
the second half of the 1790s, however, more was broken than just the French revolutionary experience. It was also an Atlantic moment, and it involved not only the Terror, but also the Haitian Revolution. What I call the 'Atlantic Thermidor' refers to this fracturing of a transatlantic revolutionary moment and experience.

These Atlantic evaluation processes of both events had rhythms and dynamics of their own. In the case of the Haitian Revolution, French white planters' demands for more autonomy in 1789 were at first widely interpreted against the background of the 'anti-imperial' American Revolution. They raised the spectre of colonial secession and put the status of the colonies within the political realm of the nation-state up for debate. Soon, however, advocates of the cause of free coloured people invoked the French 1789 Declaration of the Rights of Man and Citizen. This raised questions about the scope of the principles of this declaration and the constitutional unity of the empire. Concretely, was the colonial empire (to become) part of the single, constitutionally unified nation-state? Settling this issue was the precondition for the question who within the 'imperial nation-state' was eligible to become a citizen. To whom did the declaration apply? Were all inhabitants of the empire to become citizens?

These questions were in turn given a dramatic new dimension once the slave rebellion broke out in the summer of 1791 . How was this rebellion represented and discussed in American, Dutch, and French media? And if the cry for civic equality raised by free coloured people was related to the principles of rights declarations, was this also done in the case of enslaved people of African descent? The slave insurrection in Saint-Domingue, and the French decree of 1794 granting black slaves citizenship, then, unexpectedly and unintentionally, added another item to the revolutionary agenda. It also generated a great many arguments that this item should not have been on the revolutionary agenda at all. The combination of the insurrection and the perceived 'logic' of the principle of the equal Rights of Man prompted many to articulate the limits of the scope of citizenship and refute this logic.

Such debates about who was eligible to become a citizen clearly had important legal and constitutional aspects (although important differences between the legal and constitutional definitions of American, French, and Dutch citizenship existed). But as Chapter three demonstrates, these constitutional and legal debates about the scope of citizenship intertwined with questions about the civilizational and moral status of free people of colour and enslaved blacks. Given that black Africans were human beings, a basic notion most commentators accepted, on what basis were they excluded - or temporarily excluded - from citizenship rights? As I argue in Chapter four, for many American, Dutch, and French observers of the events in Saint-Domingue, the prevailing conceptual 
scheme underlying their interpretations, and ultimately their arguments for exclusion, was the distinction between 'civilized' and 'uncivilized' man (rather than the distinction between essentially different 'races'). This distinction was grounded in a family of philosophical theories of historical progress or what is sometimes referred to as stadial or conjectural history. The French decision to extend full citizenship rights to 'uncivilized savages' was, according to the great majority of the historical actors studied here, another proof of the reckless philosophical radicalism of the French Revolution. It led many Dutchmen and Americans who initially sympathized with the French Revolution to question the commonality and unity of the principles underlying the Atlantic revolutions. The Haitian Revolution, thus, not only posed challenges to the scope of citizenship, but also led Americans and Batavian revolutionaries, as well as French conservatives around 1800, to believe that French revolutionary conceptions of citizenship were fundamentally at odds with theirs.

In considering the Terror, an obvious and crucial difference between the three republics under consideration is that it took place in France, while the American and Dutch Republics did not experience such bloody episodes in the $1790{ }^{21}{ }^{21}$ The different chronologies of revolutionary events are important to keep in mind here. Whereas the young American Republic of the early 1790 s was a post-revolutionary society with an adopted constitution and Bill of Rights (1791), and whose war with the British was over, France was at that time in the midst of revolutionary turmoil and war. The Dutch, on the other hand, had gone through the experience of the largely urban and failed Patriot uprising of 1786-1787. Until January 1795 they had not experienced a fullfledged revolution at all; and when Batavian revolutionaries overthrew the Orangist regime, they depended heavily on the French armies of the Thermidorian regime.

Despite these important differences in political circumstances, in all countries the Terror, if in varying degrees and for different reasons, bred anxiety about the possibly intense and violent nature of partisanship and opposition. American Federalists, French Thermidorians, as well as a considerable number of moderate Batavian revolutionaries came to hold deep suspicions about politicized popular societies as embodiments of a faction-ridden citizenry.

21 This is not to say that they were without (state) violence, arbitrary arrests, oppression, and purges. See N. van Sas, Bataafse Terreur: De betekenis van 1798 (Nijmegen: Vantilt, 2011); J.M. Smith, Freedom's Fetters: The Alien and Sedition Laws and American Civil Liberties (Ithaca, N.Y.: Cornell University Press, 1956). 
They argued that popular societies had played an essential role in the coming of the Terror and were eager to exclude certain social classes from (direct) participation in politics. The Terror was interpreted - and instrumentalized as throwing a sinister light on popular societies (or 'clubs') as platforms of citizenship activism, although the internal political circumstances and debates in the three republics varied. While French Thermidorian politicians from October 1794 onward eagerly sought to dismantle the Jacobin clubs, American Federalists grew increasingly critical of the rise of so-called Democratic-Republican societies between 1793 and 1795. Batavian revolutionaries, on the other hand, had a more ambiguous relationship toward popular societies. After all, they only entered the unknown waters of revolutionary turmoil in 1795 . In the opening stages of the Batavian Revolution, popular societies were considered wells of revolutionary energy and support, especially by the vocal democraticrepublican wing. Yet there was also a widespread awareness of what a broadly inclusive, politicized citizenry organized in popular societies could lead to. For strategic reasons, moreover, most Batavian revolutionaries sought to avoid any association with unruly French 'Jacobins'. The exact timings and local manifestations of the Atlantic Thermidor, then, varied. But the fracturing took place over debates about the limits and nature of revolutionary citizenship ideals.

For analytical purposes, the dimensions of revolutionary citizenship being studied in this book can be summed up as follows: in considering the questions and anxieties emerging from the Haitian Revolution I focus mainly on the scope of citizenship: who is deemed eligible to become a citizen? In my analysis of the reactions to and reflections on the French revolutionary Terror I focus mainly on the ideal of political participation, and to some extent on the question of scope: what is a citizen supposed to do within the political realm? What are appropriate platforms of citizen activism? And who is considered to be qualified to live up to the revolutionary political ideals of citizenship?

Although these dimensions of citizenship can be analytically distinguished, studying the discursive repercussions of the Haitian Revolution and the Terror in tandem reveals something important. Their partial contemporaneity ensured that the picture of anarchy and popular violence in France could all too easily be related to the slave insurrection and civil war in Saint-Domingue. By the end of the 179os disillusioned critics were keen to lump them together as the combined proof of a hopelessly naïve and failed universalist experiment. Although both events generated a diversity of responses, one central line of interpretation I single out is the association of both events with a French Revolution that had careered off track due to a radicalized ideology 
based on universalistic notions of equality and political participation. This Atlantic Thermidorian moment fractured the idea of an Atlantic project of citizen emancipation. The disintegration of the vision of a transatlantic revolutionary movement, underpinned by highly universalistic civic ideals, left a vacuum to be filled by more national interpretations of what it means to be a citizen.

\section{3}

A Comparative Approach to the 'Atlantic Thermidor'

This study adopts a comparative approach to throw into relief the ways in which an Atlantic discourse of overlapping citizenship ideas and ideals came to diverge into more nationalized citizenship discourses. In doing so, I revisit the field of comparative late eighteenth-century revolutions, originally opened up in the mid-1950s and early 196os, when Robert R. Palmer and Jacques Godechot conceived the 'age of Atlantic revolutions' as an object of historical analysis. Their vigorous thesis held that the various late eighteenth-century rebellions and upheavals around the Atlantic rim were, in the words of Palmer, part of 'a single revolutionary movement'.22 While Godechot's Les Révolutions, $177^{-}$ 1799 was still framed within a rather francocentric and expansionist scheme, Palmer's The Age of the Democratic Revolution presented a less hierarchical, and more explicitly 'democratic' panorama. Notably, Palmer marked the Dutch Patriot uprising of the 1780 s as the most important European reform movement before the outbreak of the French Revolution, while the subsequent Batavian Republic $\left(1795^{-1801}\right)$ took pride of place as the most prominent

22 J. Godechot, Les Révolutions, 1770-1799 (Paris: Presses Universitaires de France, 1963). Whereas the French edition spoke of 'les révolutions' in the plural, in the English translation it was rendered a singular Atlantic revolution: France and the Atlantic Revolution of the Eighteenth Century, 1770-1799, trans. H.H. Rowen (New York: Free Press, 1965); R.R. Palmer, The Age of the Democratic Revolution: A Political History of Europe and America, 1760-180o (Princeton, N.J.: Princeton University Press, 2014 [1959-1964]), p. 8. For background on Palmer and Godechot see B. Bailyn, Atlantic History: Concept and Contours (Cambridge, MA: Harvard University Press, 2005), pp. 3-30, and the special issue of Historical Reflections/Réflexions Historiques 37 (2011): 'Robert Roswell Palmer: A Transatlantic Journey of American Liberalism', edited by L. Hunt et al. An older, pioneering work that treats the American and French revolutions together is B. Faÿ, L'Esprit révolutionnaire en France et aux États-Unis à la fin du XVIIIe siècle (Paris: Edouard Champion, 1925). The 1927 English translation was reprinted in 1966: The Revolutionary Spirit in France and America: A Study of moral and intellectual Relations between France and the United States at the End of the Eighteenth Century (New York: Harcourt, Brace \& World, 1927; repr. ed. New York: Cooper Square, 1966). 
member of the (European) 'sister republics'. ${ }^{23}$ Godechot and Palmer's historical synthesis gave coherence to what had often been treated as disperse and separate movements. ${ }^{24}$ One crucial - and heavily contested - corollary of their narrative was that neither the American nor the French Revolution appeared as unique or exceptional.

Given today's omnipresence of the phrase 'age of Atlantic revolutions' (or Age of Revolution(s)), it is easy to forget that the national explanatory framework remained dominant for decades. ${ }^{25}$ The 'Palmer-Godechot thesis' was actually not generally accepted. ${ }^{26}$ On both sides of the Atlantic, historians have returned, and sometimes continue to return, to longstanding historiographical commonplaces that claim exceptionality for 'their' revolution. ${ }^{27} \mathrm{Put}$

23 Or 'one great movement'. Palmer, The Age of the Democratic Revolution, pp. 6, 8. On European sister republics, see E. Jacobs, J. Oddens, and M. Rutjes (eds.) The Political Culture of the Sister Republics, 1794-1806. France, The Netherlands, Switzerland, and Italy (Amsterdam: Amsterdam University Press, 2015); P. Serna (ed). Républiques sœurs. Le Directoire et la Révolution atlantique (Rennes: Presses Universitaires de Rennes, 2009); A. Jourdan, 'Buitenbeentjes tussen de zusterrepublieken. De Bataafse Republiek in internationaal perspectief', in: F. Grijzenhout, W. Velema, N. van Sas (eds.) Het Bataafse experiment. Politiek en cultuur rond 1800 (Nijmegen: Vantilt, 2013), pp. 155-184.

24 It should be noted that in their approach Godechot and Palmer differed more than is sometimes acknowledged. Much more than Palmer's political history, Godechot's interpretation departed from structuralist and materialist assumptions.

25 Over the last years a number of volumes dealing with various aspects of the 'age of revolutions' have appeared: M. Albertone and A. de Francesco (eds.), Rethinking the Atlantic World: Europe and America in the Age of Democratic Revolutions (Basingstoke: Palgrave Macmillan, 2009); R. Bessel, N. Guyatt, J. Rendall (eds.) War, Empire and Slavery, 1770-1830 (Basingstoke: Palgrave Macmillan, 2010); J. Innes and M. Philp (eds.) Re-imagining Democracy in the Age of Revolutions: America, France, Britain, Ireland 1750-1850 (Oxford: Oxford University Press, 2013); S.P. Newman and P.S. Onuf (eds.) Paine and Jefferson in the Age of Revolutions (Charlottesville, VA: University of Virginia Press, 2013); P. Serna, A. de Francesco and J. Miller (eds.) Republics at War, 1776-1840. Revolutions, Conflicts, and Geopolitics in Europe and the Atlantic World (Basingstoke: Palgrave Macmillan, 2013); Serna (ed.), Républiques sœurs.

26 For an extensive overview of the historiographical debate about the 'two revolutions question', see A. Potofsky, 'The One and the Many: The Two Revolutions Question and the "Consumer-Commercial" Atlantic, 1789 to the present', in: Albertone and De Francesco (eds.), Rethinking the Atlantic World, pp. 17-45.

27 Classical 'exceptionalist' interpretations of the American Revolution can be found in L. Hartz, The Liberal Tradition in America: An Interpretation of American Political Thought since the Revolution (New York: Harcourt, Brace and World, 1955); R. Hofstadter, The American Political Tradition and the Men who made it (New York: A.A. Knopf, 1948); E. Morgan, The Birth of the Republic, 1763-89 (Chicago, IL: University of Chicago Press, 1956). According to the classical Marxist interpretation of the French Revolution associated with Albert Mathiez, Georges Lefebvre and Albert Soboul, the French Revolution was logically the only true revolution, since only the French Revolution in their view was really a 'social' 
schematically, the American Revolution has been presented in such works as an essentially political, moderate, but ultimately successful revolution; the French as a radical, social revolution, ending in bloodshed and dictatorship. ${ }^{28}$ Although more political-philosophical than historical in nature, Hannah Arendt's study On Revolution (1963), perhaps the most famous of them all, basically reaffirmed the French-American revolutionary divide by pointing out the absence of the 'social question' in the American case. ${ }^{29}$

Both interpretations - 'the one and the many' - are attractive. They provide an orderly presentation of complex historical phenomena. However, in my view they are also too static and imprecise. The decade of the 1790 s was a period of profound uncertainty, convulsive political disruptions, and conceptual innovations. If Americans, Dutchmen, and Frenchmen saw themselves as part of a larger transatlantic whole, they also perceived this transatlantic world as being shaken to its foundations. Within these circumstances, positions were not carved out, evaluations of each other's revolutions not set in stone. As Seth Cotlar has recently demonstrated, the early American Republic of the $1790 \mathrm{~s}$ witnessed a 'rise and fall of transatlantic radicalism. ${ }^{30}$ Although this is a fruitful way of describing the evolving transatlantic political culture from an American perspective, from a comparative point of view including French as well as Dutch perspectives, the story is inevitably more complex. Take for example February 1794, the month in which the French National Convention adopted the decree turning black slaves into French citizens and Robespierre delivered

revolution in the sense that it radically destroyed the existing social structures. G. Lefebvre, Quatre-Vingt-Neuf (Paris: Maison du Livre français, 1939); A. Mathiez, La Révolution française, 3 vols. (Paris: Armand Collin, 1922-1927); A. Soboul, Histoire de la Révolution française, 2 vols. (Paris: Éditions sociales, 1962).

28 More recent comparative studies that basically maintain the divide between the French and American revolutions include G. Gusdorf, Les Révolutions de France et de l'Amérique. La violence et la sagesse (Paris: Perrin, 1988); P. Higonnet, Sister Republics: The Origins of French and American Republicanism (Cambridge, MA: Harvard University Press, 1988); S. Dunn, Sister Revolutions. French Lightning, American Light (New York: Faber and Faber, 1999). For the most influential statement that the American Revolution was a 'radical' revolution, see G.S. Wood, The Radicalism of the American Revolution (New York: Vintage Books, 1991). See, however, the forum 'How Revolutionary was the Revolution? A Discussion of Gordon S. Wood's The Radicalism of the American Revolution', in: The William and Mary Quarterly $5^{1}$ (1994), pp. 677-716. For a critique of overly simplistic ascriptions of liberal and republican traditions to American and French (intellectual) history and the alleged divide between the two, see M. Hulliung, Citizens and Citoyens. Republicans and Liberals in America and France (Cambridge, MA: Harvard University Press, 2002).

29 H. Arendt, On Revolution (New York: Viking, 1963).

30 S. Cotlar, Tom Paine's America: The Rise and Fall of Transatlantic Radicalism in the Early Republic (Charlottesville, VA: University of Virginia Press, 2011). 
his famous speech justifying the Terror. At this particular moment, the Dutch Republic was a pre-revolutionary, the French Republic a revolutionary, and the American Republic a post-revolutionary society. Although sharing frameworks of reference and dealing with similar questions, Americans, Dutchmen, and Frenchmen responded to dramatic turns and events at different moments, in different contexts, in light of their own preoccupations, and with different degrees of intensity.

My decision to narrate the transformation of a set of common revolutionary ideals in terms of convergence and divergence shares the ambition of recent studies in 'transfer history' or 'entangled history' (in French: histoire croisée; in German: Verflechtungsgeschichte) that engage with the age of revolutions to go beyond a strict historical comparison of isolated cases. ${ }^{31}$ Like historians such as Janet Polasky and Annie Jourdan who have traced the circulation, exchange, and transfer of revolutionary ideas, models, and practices, this study seeks to 'de-exceptionalize' our understanding of the French and American experiences in the age of revolutions. ${ }^{32}$ But instead of focusing on information networks

31 Hence, this study also shares the starting point of recent studies by Ashli White and Philip Ziesche that for Americans, as well as for Dutch and French revolutionaries, responses to other, foreign revolutions were important factors in shaping their conceptions of citizenship, nationhood, and the very idea of revolution as such. In her insightful study of the repercussions of the influx of immigrants from Cap Français, Saint-Domingue, to early American coastal cities such as Philadelphia and Baltimore, White claims to pursue a 'web model', focusing on the interaction between Saint-Dominguan refugees and U.S. residents. Ziesche's Cosmopolitan Patriots, in which he follows several prominent and less prominent American politicians, diplomats and publicists in Paris in the 179os, is another example of a recent study that seeks to present an 'entangled history' of Americans encountering other Atlantic revolutions, emphasizing 'process, mutual influences, and the relativity and plurality of perspective'. Despite their professed preference for an entangled or web approach, however, White's and Ziesche's accounts essentially explore American political and public culture. A. White, Encountering Revolution. Haiti and the Making of the Early Republic (Baltimore, MD: Johns Hopkins University Press, 2010), p. 7; P. Ziesche, Cosmopolitan Patriots. Americans in Paris in the Age of Revolution (Charlottesville, VA: University of Virginia Press, 2010), p. 10.

32 J. Polasky, Revolutions Without Borders: The Call to Liberty in the Atlantic World (New Haven, CT: Yale University Press, 2015). A. Jourdan, La Révolution batave entre la France et l'Amérique (1795-1806) (Rennes: Presses Universitaires de Rennes, 2008); idem, 'The "Alien Origins" of the French Revolution: American, Scottish, Genevan, and Dutch Influences', Proceedings of the Western Society for French History, 35 (2007), pp. 185-205; idem, 'The Batavian Revolution: Typical French, Typical Dutch or Typical Atlantic?', Dutch Crossing 31 (2007), pp. 271-288; idem, 'Politieke en culturele transfers in een tijd van revolutie. Nederland 1795-1805', BMGN/Low Countries Historical Review 124 (2009), pp. 559-579; idem, 'The Netherlands in the Constellation of the Eighteenth-Century Western Revolutions', European Review of History: revue européenne d'histoire 18 (2011), pp. 199-225. For methodological considerations on (political and cultural) transfer, see H. te Velde, 'Political Transfer. 
and processes of transfer, my concern is the divergence of a revolutionary citizenship discourse.

The comparative approach to the study of revolutions adopted in this book is rooted in hermeneutic and interpretive methods, a field that has recently been given fresh impetus by a volume edited by Keith Michael Baker and Dan Edelstein. ${ }^{33}$ This interpretative comparative method deviates from the body of scholarship belonging to the classical tradition of the comparative study of revolutions rooted in the social sciences, a body of scholarship that was mainly interested in material structures, causal mechanisms and outcomes. ${ }^{34}$ This book, in contrast, examines how revolutionaries understood their own actions and ideals, and the contexts in which they operated, even if such a history consists of many would-have-beens, dead ends, and disillusions. This study asks questions about the (changing) meaning of the concept of citizenship, what ideals and other concepts were associated with and invested in it, and the ways it was put to use in particular historical contexts. In that sense, my approach owes much to the historical study of concepts, ideas, and languages, as theoretically formulated by the 'Cambridge School' and Begriffsgeschichte (History of Concepts). ${ }^{35}$

An Introduction', European Review of History: Revue européenne d'histoire 2 (2005), pp. 205-221; J. Paulmann, 'Interkultureller Transfer zwischen Deutschland und Grossbritannien: Einführung in ein Forschungskonzept', in: R. Muhs, J. Paulmann, and W. Steinmetz (eds.), Aneignung und Abwehr. Interkultureller Transfer zwischen Deutschland und Grossbritannien im 19. Jahrhundert (Bodenheim: Philo, 1998), pp. 21-43.

33 K.M. Baker and D. Edelstein (eds.) Scripting Revolution. A Historical Approach to the Comparative Study of Revolutions (Stanford, CA: Stanford University Press, 2015).

34 The classical works in this tradition include: C. Brinton, The Anatomy of Revolution (New York: Norton, 1938); B. Moore, Social Origins of Dictatorship and Democracy (Boston, MA: Beacon Press, 1966); T. Skockpol, States and Social Revolutions: A Comparative Analysis of France, Russia, and China (Cambridge: Cambridge University Press, 1979); J.A. Goldstone, Revolution and Rebellion in the Early Modern World (Berkeley, CA: University of California Press, 1991). Most recently, Wim Klooster in his Revolutions in the Atlantic World: A Comparative History (New York: New York University Press, 2009) has sought to understand the American, French, Haitian, and Latin American revolutions 'on their own terms', putting international politics and inter-imperial and civil warfare at the center of his analysis, and boldly arguing against Palmer that in all revolutions democracy was 'hardly more than a by-product'.

35 I. Hampsher-Monk, K. Tilmans, F. van Vree (eds.) History of Concepts: Comparative Perspectives (Amsterdam: Amsterdam University Press, 1998); R. Koselleck, Begriffsgeschichten: Studien zur Semantik und Pragmatik der politischen und sozialen Sprache (Frankfurt am Main: Suhrkamp Verlag, 2006); Koselleck, Vergangene Zukunft; J.G.A. Pocock, Political Thought and History: Essays on Theory and Method (Cambridge: Cambridge University Press, 2009); Skinner, Visions of Politics, vol. 1: Regarding Method. 
Yet, it might be useful to explicate the ways in which my approach might be said to deviate from both. First of all, by adopting a short-term, comparative perspective my approach differs considerably from the long-term diachronic investigations of 'basic concepts' as, for example, elaborated in the Geschichtliche Grundbegriffe (Historical Basic Concepts). ${ }^{36}$ This allows me to give a more in-depth analysis of particular moments during the decisive decade of the age of revolutions in which the concept of citizenship was being redefined in unprecedented ways, and arguably, at an unprecedented pace, across a number of countries. Secondly, the focus on the 1790s, and more in particular, the Haitian Revolution and the Terror, indicates that in determining the relevant contexts that help to explain how and why people understood and made use of the concept citizen, I give most weight to the discursive repercussions of 'events'. In this, I follow Keith Michael Baker who to my mind has rightly argued that the historian 'must set aside the superficial distinction between ideas, on the one hand, and events on the other'. ${ }^{37}$ In what follows I take it that the historical agents I discuss gave meaning - sometimes similar, sometimes different and conflicting meanings - to events, thus turning events into elements of a wider web of meanings, concepts, and symbols. This does not imply that events do not exist without interpretation, but rather, as William Sewell has remarked, that 'symbolic interpretation is part and parcel of the historical event'. ${ }^{38}$ In contrast, then, to contextualist studies in the history of political thought that give most weight to linguistic contexts (and in Begriffsgeschichte to 'semantic fields'), I put emphasis on the ways in which historical actors responded to, and intellectually processed, events. Needless to say, in comparison with both

$36 \quad$ Brunner, Conze and Koselleck (eds.), Geschichtliche Grundbegriffe.

37 K.M. Baker, 'Idioms, Discourses, and Improvisation', in: T.E. Kaiser and D.K. van Kley (eds.) From Deficit to Deluge. The Origins of the French Revolution (Stanford, CA: Stanford University Press, 2011), pp. 165-197, at p. 166. Baker continues: 'The aim should not be to separate ideas from events, tracking the appearance and diffusion of the one to explain the occurrence of the other. To the contrary, the goals of the intellectual historian is to find the ideas - which is to say the meanings - within events [...] Far from being external to actions and events, ideas already exist within them, and vice versa. As identities, motivations, and goals are necessarily formulated within discourses (or other symbolic forms) that give them meaning, so are the events that emerge from the dynamic interaction of these identities, motivations, and goals. Events can be seen as to change a situation radically; they do so not in and of themselves, however, but they are given significance that is brought to bear within and upon the situation that political actors are constantly struggling to define'.

38 W.H. Sewell, 'Historical Events as Transformations of Structures', in: idem, Logics of History. Social Theory and Social Transformations (Chicago, IL: University of Chicago Press, 2005), pp. 225-270, at p. 245. See also R. Koselleck, 'Linguistic Change and the History of Events', Journal of Modern History 61 (1989), pp. 649-666. 
Cambridge School contextualism and Begriffsgeschichte, this is a matter of emphasis, not rigid distinction.

The second way in which it may be said that this study differs from the contextualist approach to the history of political thought is that my account of the 1790 s is more concerned with the reconstruction of public discourses within which the reconceptualization of citizenship in light of the Haitian Revolution and the Terror took a central place, rather than the contextualization of one or another (or several) political theorist(s). Neither is explaining to what extent certain visions of citizenship as expounded in the 179os did or did not belong to certain political languages the primary interest that drives this research. Rather, the historical analysis presented here is concerned with the question of what kind of discourse and debates the Haitian Revolution and the Terror generated and how they informed the rhetoric and thinking about citizenship.

From all (city-)states, countries, and regions within the Atlantic world that were touched by political upheavals during the age of revolutions, there are compelling reasons to comparatively examine American, Dutch, and French debates about citizenship during the 1790s. To begin with, all three countries experienced revolutions that were based on principles that, at the very least, seemed similar and were articulated in languages that had much in common (unlike, most obviously, Great Britain). Notwithstanding their differences, in all three countries the concept of citizenship was radically transformed. As we shall see in Chapter one, the fact that in all three countries declarations proclaiming the (natural) rights of men and citizen were issued, was of no small importance. They signaled that certain fundamental principles were endorsed, and thus offered a powerful new repertoire of arguments that people put to use for a variety of purposes. Conversely, they also prompted the articulation and invocation of arguments by others who wished to counter the positions taken by those who carried the logic of declarations of rights in unanticipated directions.

Secondly, all three countries were commercially, intellectually, and politically oriented toward the wider Atlantic world and were confronted with similar questions, not in the least because all were involved in the enslavement, trade, and exploitation of black Africans. Finally, all three countries were struggling in the 179os, politically and intellectually, with questions of political participation, civil order, partisanship, and national identity in light of the developments that were taking place both at home and in the wider Atlantic world.

Since the French and American revolutions have long been the subjects of comparison, including the Dutch case requires some additional explanatory remarks. First of all, the Dutch Republic was, like France, a colonial empire. One important reason to select the Dutch Republic is precisely this aspect: 
unlike, for example, the Helvetian (Swiss), or the Cisalpine (Northern Italian) 'sister' republics, the Dutch Republic was much more oriented toward the Atlantic and Caribbean world (as well as the East Indies), if only because of their colonial assets and commercial interests. ${ }^{39}$ Secondly, unlike an older mistaken historiography which has painted the Batavian Republic as a 'French puppet state', it has been convincingly demonstrated that until 1798, Dutch revolutionaries - much more so than revolutionaries in other European sister republics - could operate and debate in relative autonomy. ${ }^{40}$ Finally, the extent to which Dutch printing houses and publishers printed, translated, and distributed all the major as well as many minor texts of the eighteenth century is truly remarkable. The Dutch Republic was a book depository of the Enlightenment and the age of revolutions. ${ }^{41}$ As a consequence, many Batavian revolutionaries (as well as Orangists for that matter), were well versed in, or familiar with, the works of Frossard, Locke, Montesquieu, Paine, Price, Priestly, Raynal,

39 A pioneering study on the views of Dutch Patriots and Batavian revolutionaries on the colonies is G.J. Schutte, De Nederlandse Patriotten en de koloniën. Een onderzoek naar hun denkbeelden en optreden, 1770-180o (Groningen: Tjeenk Willink, 1974).

40 The view of the Batavian Republic as 'French puppet regime' was established by H.T. Colenbrander. See his Gedenkstukken der algemeene geschiedenis van Nederland van 1795 tot 1840, 10 vols. (Den Haag: Martinus Nijhoff, 1905-1922); idem, De Bataafsche Republiek (Amsterdam: Meulenhoff, 1908). T. Jorissen most probably coined the term 'Franse tijd' (French era) to describe the period 1795-1813. T. Jorissen, 'De Fransche Tijd', in: idem (ed.), Historische bladen (Haarlem: Tjeenk Willink, 1892), pp. 167-273. For this see J. Joor, De adelaar en het lam (Amsterdam: De Bataafsch Leeuw, 2000), pp. 28-34. The pedigree of the view that the Batavian Revolution was a historical event worth studying in its own right and that the Dutch were not simply marionettes of the French goes back to Pieter Geyl's third volume of his Geschiedenis van de Nederlandse Stam, 6 vols. (Amsterdam: Wereldbibliotheek, 1930-1959). Three other crucial interpretations of the Batavian Revolution as a genuine 'Dutch' revolution instead of a subordinate derivative from the French Revolution, are R.R. Palmer, 'Much in little: The Dutch Revolution of 1795', Journal of Modern History 26 (1954), pp. 15-35; C.H.E. de Wit, De strijd tussen aristocratie en democratie in Nederland, 1780-1848 (Heerlen: Winants, 1965); and S. Schama, Patriots and Liberators. Revolution in The Netherlands, 1780-1813 (London: Collins, 1977). See also the more recent work by Jourdan, Oddens, Rosendaal, Rutjes, Van Sas, Velema cited below. For a recent alternative interpretation which stresses the fundamental continuity of the eighteenthcentury intellectual construction of the 'moral citizen' into the nineteenth century and diminishes the importance of the Batavian Revolution as historical rift, see Mijnhardt and Kloek, 180o: Blueprints for a National Community. For an older historiographic overview, see E.O.G. Haitsma Mulier, 'De geschiedschrijving over de patriottentijd en de Bataafse tijd', in: W.W. Mijnhardt (ed.) Kantelend geschiedbeeld. Nederlandse historiografie sinds 1945 (Utrecht: Spectrum, 1983), pp. 206-227, 352-355.

41 J. Popkin, 'Print Culture in The Netherlands on the Eve of the Revolution', in: M.C. Jacob and W.W. Mijnhardt (eds.) The Dutch Republic in the Eighteenth Century. Decline, Enlightenment, and the Revolution (New York: Cornell University Press, 1992), pp. 273-291. 
Rousseau, and Voltaire, all of whom were translated into Dutch. ${ }^{42}$ This is not to imply that the Dutch readers slavishly followed and copied foreign Enlightenment authors. But from the late 1770 s and early 1780 s onwards, Dutch Patriots and (in the 1790s) Batavian revolutionaries began to draw on a transnationally shared body of radical authors in formulating their critique of the Orangist oligarchical regime. In short, although the Dutch had a very particular political-institutional history, their intellectual and political orientation in the last quarter of the eighteenth century had much in common with that of the Americans and the French.

The commonalities between the three countries, however, must not conceal their real differences. Whereas for most Dutchmen and many Frenchmen the insurrection at Saint-Domingue was a relatively distant affair, raising a set of rather specific questions about the scope of citizenship within an imperial framework, for the United States - especially the slaveholding South - the Haitian Revolution was of immediate domestic (even existential) relevance. The succession of events in revolutionary France, the radicalization and violence between the years 1792 and 1794, and the fresh memory of it in the period immediately thereafter, undoubtedly had a more direct and intense impact on the domestic political climate in France, and to a lesser extent, the Dutch Republic. Especially for the United States, the French Terror was in that sense a more distant affair. But what all three countries nonetheless had in common was that the forging - and reassessment - of revolutionary ideals was a contingent process of intellectual and political interaction between the 'local' and a 'transnational' Atlantic revolutionary world.

The book is structured as follows. The first chapter argues that in the last quarter of the eighteenth century, a substantial and influential group of American, Dutch, and French politicians, journalists, political thinkers, and publicists,

42 Dutch translations appeared of (sometimes several) works by such authors as John and John Quincy Adams, Brissot, Condorcet, St. John de Crèvecoeur, Hume, Mirabeau, (William) Robertson. Many English works were also read in French translation. Systematic overviews are lacking, but there are some individual studies: W. Gobbers, Jean-Jacques Rousseau in Holland. Een onderzoek naar de invloed van de mens en het werk (ca. 1760-ca. 1810) (Gent: Secretariaat van de Koninklijke Vlaamse Academie voor Taal- en Letterkunde, 1963); W.R.E. Velema, 'Republican readings of Montesquieu: The Spirit of The Laws in the Dutch republic', History of Political Thought 18 (1997), pp. 43-63. See also W. Prins, 'Hume, genoemd. Een inventarisatie van Nederlandstalige reacties op David Hume, 1739-180o' (MA-thesis, University of Amsterdam, 2011). 
started to articulate visions of citizenship that shared important commonalities. On both sides of the Atlantic these resemblances were mutually recognized and cultivated. This process, or moment, of converging citizenship ideals accelerated in the 1780 os and culminated in the immediate period after the outbreak of the French Revolution. One important aspect I single out in this moment of converging citizenship ideals is the 'act' of declaring rights in written, public documents, as underpinning of a new model of citizenship. Although the practice of declaring rights was not particularly revolutionary in and of itself, some of the principles contained in these declarations undoubtedly were.

Chapters 2 to 4 analyze the ways in which Americans, Dutchmen, and Frenchmen responded to the succession of events on Saint-Domingue and the interaction with metropolitan France. Chapter two focuses on the period from mid-1789 to the summer of 1791. It shows how the question of equal citizenship within the colonial empire was put on the French revolutionary agenda and how revolutionary Saint-Domingue was interpreted in the United States both in light of their own anti-imperial revolution and in light of the 'rights talk' the French Revolution seemed to re-ignite in particular with reference to SaintDomingue's free coloured population. Chapter three shows that the slave insurrection of 1791 was portrayed in American, Dutch, and French media as ushering in a barbaric civil war which incited the articulation of a whole new set of considerations about the nature of black slaves. It shows that black slaves were often portrayed as uncivilized savages unfit for modern republican citizenship. French abolitionists who advocated the constitutional unity of the empire too rejected immediate emancipation on this basis, while Americans in the slave-holding South reviled the 'murderous' imperial policies of the 'Jacobins'. Chapter four turns to the debates in the Dutch National Assembly, the centrality of the specter of Saint-Domingue in these debates, and the widely shared abhorrence of the French imperial model of citizenship and its alleged consequences. By the late 1790s, the philosophical recklessness of the French 'experiment' was widely decried in all three countries.

Chapters 5 to 7 are concerned with the question of how the violence, radicalization, and terror of the French Revolution were represented and interpreted, and how these representations and interpretations came to function in conceptions of citizenship. It presents these processes by dealing with the French, American, and Dutch cases in separate chapters. The fifth chapter shows that in Thermidorian France, the notions of 'good citizen' and 'bad citizen' emerged in speeches and writings. This distinction served, on the one hand, to purify the concept citizen of associations with the Terror. It was, on the other hand, employed as an instrument to mobilize French citizens behind a program of national reconciliation (which failed miserably). This program of 
national reconciliation went hand in hand with a depoliticization of the concept of citizenship: by disentangling citizenship from dangerous political participation and partisanship in 'popular societies', such visions of citizenship redirected civic virtues toward the domain of society, commerce, arts, and industriousness, making citizenship more exclusive and elitist.

The sixth chapter on the early American republic of the 179os situates the interpretation of the radicalization of the French Revolution in the emerging partisan opposition between so-called Federalists and Republicans. It demonstrates that Americans were initially simply amazed by the astonishing series of revolutionary events. Over time Federalists began to fear the contagion of radicalism as embodied in democratic-republican societies and what is known as the 'Whiskey Rebellion'. They accordingly appropriated representations of the French Terror in their arguments against democratic-republican conceptions of a broadly based, politically engaged citizenry. The final section of this chapter argues that in the second half of the 179os, with the XYZ affair and the ensuing Franco-American naval war (or 'Quasi-War') a more decisively antiFrench and anti-Jacobin discourse developed. Citizenship came to be articulated in more national, 'American' terms; after 1798 even Republican voices began to disassociate American citizenship from the French model.

In the seventh and final chapter I show that the dynamic in the Dutch (and from 1795) 'Batavian' Republic, was again quite different. For Batavian revolutionaries the legacy and example of the French Revolution were ambiguous from the very beginning. They had to walk a thin line between not being associated with French excesses while holding up the necessity of a 'revolutionary' transformation of the Dutch political regime. The Terror was employed in arguments in favor of a 'national' (centralized) constitution so as to prevent French 'scenes'. In addition, Batavian revolutionaries were wary of too much direct 'popular' interference. Contrary to the American Republic, however, the Batavian Republic was still in a state of revolution. The Terror was depicted as something peculiarly 'French': the Dutch should follow their own 'national' model and should therefore not be too afraid of the French example. This led, among other things, to an articulation of citizenship in 'national' terms, but in a different way than was the case in the American republic. After June 1798, however, the French began to tighten the reins, eventually turning into an occupational force. Consequently, mainstream Dutch visions of citizenship became permeated with a general disillusion about the age of revolutions as a whole.

The epilogue recapitulates and puts into a broader perspective the three major themes that dominated the responses to, and reflections on the Haitian Revolution and the Terror: the view that large groups in society only gradually reach a sufficient state of enlightenment or civilization to attain full political 
citizenship; the nature, extent, platform, and desirability of citizen participation in politics; and the disintegration of the idea of a transatlantic revolutionary movement into nationalized citizenship discourses. On this basis, the epilogue reconsiders the age of revolution as a turning point in the history of citizenship. 


\section{'The Kindred Spirit Tie of Congenial Principles'}

'The word citizen', the mid-August 1789 issue of one of the most eagerly read journals of the early years of the French Revolution Révolutions de Paris stated, 'expresses the quality of an individual considered as a participant in legislative or sovereign power'. 'It is thus an absurdity to speak of a citizen of Paris [...] We are citizens of France.' That same year, the first historian of the American Revolution, David Ramsay, declared: 'A citizen of the United States, means a member of this new nation. The principle of government being radically changed by the revolution, the political character of the people was also changed from subjects to citizens'. In Ramsay's view, 'The difference is immense'. Subject means 'one who is under the power of another; but a citizen is an unit of a mass of free people, who, collectively, possess sovereignty'.2 Six years later, in February 1795, one month after the outbreak of the Batavian Revolution, the Dutch journal De republikein (The republican) told its readers in a similar vein that, 'As thoughtful, enlightened, and free Citizens, you are in command of the organization of government', an 'inalienable right of every Nation'. The 'Republican', the article went on, a 'FREE MAN', 'recognizes in society no-one except as his equal' and 'knows no more magnificent title than Citizen'. ${ }^{3}$

Citizen was a key concept in the revolutionary vocabulary employed in the late eighteenth-century American, French, and Dutch revolutions. In the late 1780 s and early 1790s, a considerable and influential group of American, Dutch,

1 Révolutions de Paris, no. 6, 16-22 August, 1789, p. 10 (italic in original). On Révolutions de Paris, see J. Censer, Prelude to Power. The Parisian Radical Press, 1789-1791 (Baltimore, MD: Johns Hopkins University Press, 1976); H. Guénot, 'Révolutions de Paris (Les)' in: A. Soboul (ed.), Dictionnaire historique de la Révolution française (Paris: Presses Universitaires de France, 1989), pp. 907-908; P. Rétat, 'Forme et discours d'un journal révolutionnaire: Les Révolutions de Paris en 1789', in: C. Labrosse, P. Rétat, and H. Duranton (eds.), L'instrument périodique: La fonction de la presse au XVIIIe siècle (Lyon: Presses Universitaires de Lyon, 1986), pp. 139-178.

2 D. Ramsay, A Dissertation on the Manners of Acquiring the Character and Privileges of a Citizen (n.p., 1789), p. 3 (italic in original). On Ramsay, see A.H. Schaffer, To be an American: David Ramsay and the Making of American Consciousness (Columbia, S.C.: University of South Carolina Press, 1991).

3 De republikein I, no. 2, p. 18 (italic in original). On De republikein, see R. Koekkoek, "Eene waare en vrije Republiek". Jan Konijnenburg, De republikein en de uitvinding van de moderne republiek', De achttiende eeuw 42 (2010), pp. 236-26o; S. Vuyk, 'De republikein van Jan Konijnenburg (februari 1795-augustus 1797)', in: P. van Wissing (ed.) Stookschriften: pers en politiek tussen 1780 en 1800 (Nijmegen: Vantilt, 2008), pp. 217-229. 
and French politicians, journalists, publicists, and political thinkers began to articulate conceptions citizenship in terms of the rights of man, civic equality, popular sovereignty, nation and constitution. Importantly, they explicitly drew attention to the wider Atlantic revolutionary constellation in which they formulated these ideals. To their minds, their revolutions and revolutionary ideals transcended national boundaries. Often they referred to each other's revolutions as well as to each other's constitutions and declarations as examples and sources of inspiration. In part for strategic and rhetorical reasons, but also because many genuinely believed so, they argued that their 'national' cause of citizen emancipation was part of a momentous, Atlantic-wide upheaval.

Perhaps one of the most important Atlantic moments of converging revolutionary citizenship ideals was the summer of 1791 , when a contentious debate was fought out in the American Republic's most prominent newspapers about Thomas Paine's recently published Rights of Man. At stake were the benefits and defects of the English constitutional system as defended by Edmund Burke, and the evaluation of the swift regime change in revolutionary France. In the midst of it, on July 5, 1791, an author under the pseudonym of 'Agricola' in Dunlap's American Daily Advertiser, a fairly established Philadelphian Republican newspaper, commented on the French Revolution:

The emancipation of so great a number of our fellow creatures, is a suitable, and it is a dignified subject of congratulation: - the late glorious revolution in France presents this grand subject of joy to the feelings of humanity. The regeneration of so great and powerful a kingdom-the renovation of its rights, and the exaltation of its slaves to the high and dignified character of citizens, are events so analogous to the experience of these United States, that true Americans cannot hear of them without taking a deep interest in their benefits, and bestowing the benevolent wish of 'Esto perpetua' to the newly risen glory of France, and the newly acquired liberty of their citizens! ${ }^{4}$

4 Dunlap's American Daily Advertiser (Philadelphia, Pennsylvania), July 5, 1791. The piece was reprinted in the foremost Federalist newspaper Gazette of the United States (Philadelphia, Pennsylvania) of July 23, 1791.

In many American newspapers Paine's Rights of Man was advertised as 'Response to Mr. Burke's Attack on the French Revolution'. Paine's pamphlet became a highly inflammable issue in American public debate as Secretary of State Thomas Jefferson had forwarded it to a publisher in Philadelphia accompanied by a note saying that he wished publication would help 'correct political heresies which have sprung up among us', referring to sitting vice president John Adams's Discourses on Davila (1790), a critical assessment of the French Revolution in which Adams advocated moderation and rule by a 'natural' aristocracy. The printer of 
The next month, on August 30 and 31, both the Gazette of the United States and the Federal Gazette published a letter by the French National Constituent Assembly (signed by its president, Jean-Xavier Bureau de Pusy) to the members of the Pennsylvania House of Representatives. Earlier that year, Pennsylvanian representatives had expressed to their French fellow representatives 'their sympathetic feelings on the subject of their virtuous exertions in the cause of freedom' in a letter addressed to the National Assembly where it was read aloud on June $2 .{ }^{5}$ They had congratulated their French colleagues on their act of undertaking a revolution 'founded on that pure and elementary principle; that the people are the source of power'; and that this power is 'naturally inherent' in the people, and can only be derived from them. 'The truth of this hallowed maxim', according to the Pennsylvanian representatives, was also 'the pride and boast of our American constitutions'. At the end of the letter they had expressed their hope 'that other nations of Europe, from the influence of your example, will learn to value and vindicate the rights of man' ${ }^{6}$

In their reply, signed on June 6 and published in American newspapers a little less than two months later, Bureau de Pusy let their Pennsylvanian fellow

Paine's pamphlet published Jefferson's note, thus putting Jefferson in an awkward position. Adams felt that a response would be beneath his dignity and would make the public impression of disunion only worse. But his son John Quincy Adams felt no such hesitations. In just over six weeks he penned down eleven essays (comprising almost sixteen thousand words) which were published in the Boston Columbia's Centinel between June 8 and July 27, 1791, under the pseudonym 'Publicola'. Numerous refutations and replies appeared in the Columbian Centinel ('Brutus'), and the Independent Chronicle ('A Republican', 'The Ploughman', 'The Watchman'). 'Agricola's' piece in Dunlap's American Daily Advertiser was also addressed to Publicola. For background, see M. Daniel, Scandal \& Civility. Journalism and the Birth of American Democracy (Oxford: Oxford University Press, 2009), 72-76; C.N. Edel, Nation Builder.John Quincy Adams and the Grand Strategy of the Republic (Cambridge, MA: Harvard University Press, 2014), pp. 55-77. A collection of seven of Adams's letters appeared in a Dutch translation (under his father's name): J. Adams, Antwoord op het werk van den heer Thomas Paine, getiteld Rechten van den mensch (Haarlem: Walgré, 1793).

5 The letter, signed by the Speaker of the Pennsylvanian House of Representatives, William Bingham, was sent by the French ambassador in the United States to the President of the French National Assembly. A translation of the letter was read by the President immediately after he had read another letter by Thomas Jefferson expressing his gratitude to the Assembly for paying homage to Benjamin Franklin who had passed away in April the year before. After the reading of the letter of the Pennsylvanian legislature, the liberal constitutional monarchist Fréteau de Saint-Just (not to be confused with Louis Antoine Saint-Just), argued for multiplying commercial relations with a people who shared a similar political outlook and similar principles. At his instigation, the National Assembly decreed the king to open renegotiations with the United States on a new commerce treaty. J. Madival et al. (eds.) Archives parlementaires de 1787 à 186o, 127 vols. (Paris: Librairie administrative de P. Dupont, 1862) [hereafter: $A P$, followed by volume number], vol. 26, pp. 708-709.

6 The Gazette of the United States (Philadelphia, Pennsylvania), April 23, 1791. 
representatives know on behalf of the French National Assembly that 'it was grateful $[. .$.$] to hear, resounding from afar, prompted by fraternal affection, the$ congratulatory voice of America' (I insert the French original where the translation deviates). ${ }^{7}$ Bureau de Pusy answered that ${ }^{~}$ We too are establishing (under the constitutional authority of a king) that liberty which you have been able to secure under governments of a republican form'. According to the National Assembly's President, Frenchmen and Americans agreed on several principles, namely that liberties are not to be derived from 'chartered grants or privileges', on the 'sacred sovereignty of the people' ('l'éternelle souverainité), and on the 'equality of ranks' ('l'égalité civile'). But it was only in the 'trans-Atlantic world' ('Il fallait traverser l'océan') - 'T was there, amongst an infant people, pure and incorrupt, that the higher virtues were to be found' and the 'seeds of this precious Liberty' could flourish. He admitted that 'France is fully sensible ('n'oublier point') of the benefits she has derived from the influence of your example: she gratefully remembers that it was in the bosom of Pennsylvania, distinguished for her wisdom, that the legislators of America first announced to the world, the true principles of the social system ('l'art social'). ${ }^{8} \mathrm{He}$ admitted that France had some difficulties 'to copy the example'. It took 'the enlightened energy and unremitting efforts of a numerous people' to bring about a revolution. 'But at length the revolution is effected, and already do the rights of man, engraved on the most durable materials adorn the temples of liberty in the two hemispheres'. The National Assembly ended its reply by restating the hope that the two countries would ever closely unite 'by the kindred spirit tie of congenial principles, increase their mutual relationship, cement their interests, and perpetually recall to their recollection, that they are reciprocally indebted to each other for the recovery of their freedom ('qu'elles sont libres l'une pour l'autre'). 9

Yet another four months later, on December 7,1791 , the Dutch journal De leerzame praat-al (The educational chatter box), edited by Bernardus Bosch, a protestant minister, Patriot publicist, editor, and future leading Batavian revolutionary, published an article entitled 'On the natural rights of man

7 For the French text, see $A P$ 27, p. 14.

8 French américanistes had praised the 1776 Pennsylvanian constitution since the mid-1780s for its unicameral legislature, which offered an important counterpoint to the British model. The 1790 amendments to the Pennsylvanian constitution, however, introduced a bicameral legislative. The term l'art social was the key term with which the Journal de la Société de 1789 was concerned. Sieyès and Condorcet founded the Société de 1789 and made most contributions to its journal. See K.M. Baker, 'Politics and Social Science in eighteenth-century France: The Société de 1789', in: J.F. Bosher (ed.) French Government and Society 1500-1850 (London: Athlone Press, 1973), pp. 208-230.

9 The Federal Gazette and Philadelphia Daily Advertiser (Philadelphia, Pennsylvania), August 30, 1791; The Gazette of the United States (Philadelphia, Pennsylvania), August 31, 1791. 
and citizen'. It lashed out at Burke, maintaining that his attack on the French Revolution was completely unfounded, as Thomas Paine's Rights of Men had shown, a pamphlet 'every Patriot must read'. Recalling the venerable deeds of Washington and Lafayette during the American and French revolutions, the article reproduced the 1789 French Declaration of the Rights of Man and Citizen which 'every member of a society must imprint in his heart'.10 In a pamphlet published two years later, Bosch under the pseudonym of Vrijhart (free heart) underscored the Dutch Republic's need for a 'true constitution'. Only under a true constitution equality 'as human beings' could be safeguarded; only under a true constitution, citizens could 'enjoy their natural rights' and 'unite as one body'. A constitution would enable 'the people', 'THE SUPREME SOVEREIGN', to elect their representatives. 'America' had led the way in this respect, Bosch explained just like the French National Assembly's letter to the Pennsylvanian House of Representatives had done a few years earlier. But it was France who 'let us contemplate a well-organised society, provided us with a perfect body; let us contemplate a Constitution, in which the natural rights [and] the dignity of humanity are splendidly restored'.11 After laying out the plan for arriving at a constitution for the Dutch, Bosch claimed that such a constitution 'will elevate the name of citizens.' ${ }^{2}$

The language of the letters exchanged between the French National Assembly and the Pennsylvanian House of Representatives was similar to that of the Dutch publicist Bosch, similar to that of 'Agricola', and similar to that of Ramsay, Révolutions de Paris, and De republikein. Whether they had already gone through a revolution, were in the middle of it, or were planning one, these politicians, journalists, and publicists came to share the ideal that popular sovereignty was vested in the body of citizens; they agreed upon the equal civic standing of citizens and their entitlement to the rights of man; and they were convinced that these principles needed to be cemented in a formal written constitution. And they were keen to point out that in pushing these ideals they took part in a larger transatlantic revolutionary moment.

Remarkably, the Americans, Frenchmen, and Dutchmen who considered themselves to be involved in such a transatlantic project did so while coming from very different political backgrounds, drawing on diverse institutional and intellectual traditions of citizenship and subjecthood: they were (or used to be) subjects of an absolutist monarchy, 'settler-subjects' of overseas colonies

10 De leerzame praat-al, vol. 2, no. 49 (December 7, 1791), pp. 385-392, at pp. 387, 392 (italic in original). De leerzame praat-al appeared in Amsterdam between 1790 and 1792. It was coedited by the female literary author and publicist Petronella Moens. Anonymus [B. Bosch], Vrijhart aan het volk van Nederland over de waare constitutie (n.p., 1793), pp. 2-3. 
within a British empire, and citizens of a highly urbanized confederal Republic. ${ }^{13}$ Yet, despite the diversity of historical trajectories and backgrounds of notions of citizenship, many Americans, French and Dutch revolutionaries developed a mutual awareness and appreciation of a commonality of principles, of 'spirit', as it was often called. In their perception, however short-lived this perception turned out to be, they shared similar principles, spoke the same language, employed the same concepts, and pursued similar ideals. ${ }^{14}$

Of course, the practical and constitutional translation of these principles and ideals of citizenship was intensely debated and worked out differently in each country. What boundaries were set to the scope of citizenship varied too. But many of the specific details of the different regimes citizenship regimes were lost on Americans, Frenchmen, and Dutchmen commenting on each other, or deliberately and conveniently glossed over. What they recognized, shared, and propagated was not one formal constitutional definition of citizenship, but a transatlantic family of overlapping citizenship ideals.

It was this transatlantic mind-set or frame of mind - the sense of taking part in a common project - the parallel formation of which took place within what were still largely national communication communities, that was put to the test by the Haitian Revolution and the Terror. How did the discourse of this transatlantic mind-set take shape? What forms did it take?

Rights Declarations and the Constitutional Framework of Citizenship

Bernardus Bosch's 1791 contention that American revolutionaries had led the way in innovating constitutional thought was widely accepted among his fellow Dutch Patriots. In the late 1770 s and early 1780 , the political ideas

13 R.R. Beeman, The Varieties of Political Experience in Eighteenth-Century America (Philadelphia, PA: University of Pennsylvania Press, 2004); J.P. Greene, The Constitutional Origins of the American Revolution (Cambridge: Cambridge University Press, 2010); Kettner, The Development of American Citizenship; Sahlins, Unnaturally French; M. Prak, The Dutch Republic in the Seventeenth Century (Cambridge: Cambridge University Press, 2005), esp. pp. 153-200; idem, 'The Dutch Republic as a Bourgeois Society', BMGN/The Low Countries Historical Review 125 (2010), pp. 107-138; C.C. Wells, Law and Citizenship in Early Modern France (Baltimore, MD: Johns Hopkins University Press, 1995); C. Yirush, Settlers, Liberty, and Empire: The Roots of Early American Political Theory, 1675-1775 (Cambridge: Cambridge University Press, 2011).

14 Of course, other revolutionary movements in Austrian Belgium, Switzerland, and Poland could be mentioned. See A. Jourdan, 'Tumultuous Contexts and Radical Ideas (1783-1789). The "Pre-Revolution" in a Transnational Perspective', in: D. Andress (ed.), The Oxford Handbook of the French Revolution (Oxford: Oxford University Press, 2015), pp. 92-108. 
employed - and symbolised - by revolutionary American colonists had fallen on fertile ground. The political concept of citizenship based on the rights of man and the principle of popular sovereignty as articulated in American state declarations and constitutions were particularly attractive to many Dutch patriots as well as reform-minded Frenchmen. The American state declarations and constitutions captured and summarized much of the spirit of the age. These documents gave succinct expression to some of the most important conceptual innovations at the time, including the concept of constitution itself. Widely translated, published, debated and commented upon, the American state declarations and constitutions of $1776-1780$ stood out for their simplicity, convenient arrangement, and translatability. As David Armitage and Dan Edelstein have recently observed, declarations became a 'genre' onto itself: 'a declaration is not too long; it is usually prefaced by a preamble; it is composed in short paragraphs or articles; and it is written in simple, axiomatic language. ${ }^{15}$ Unlike philosophical tomes, these declarations were relatively straightforward and easily accessible to a broad public. Their form and universalistic language rendered them easily transferable to other countries.

It was not only the language and form of constitutions and declarations that could inspire, be copied, amended, and emulated. Declaring rights was also an 'act', as Lynn Hunt and Marcel Gauchet have emphasized. ${ }^{16}$ As manifesto's they presented an ideological rupture, a founding moment of a new order. They could be invoked as a legitimation of revolutionary action. As such, they became transatlantic carriers of revolutionary principles underlying a conception of citizenship for a new era. They were vehicles of a converging, revolutionary citizenship discourse.

The innovation of enumerating rights in written documents should not be overstated. Declaring rights in charters, bills, and compacts was anything but new. In early modern Europe, it was a fairly common tradition stretching back to the Middle Ages through which rulers and subjects laid down in writing their rights and mutual obligations. ${ }^{17}$ These older compacts and charters, however, were always concluded with a lord or king whose promise to respect the rights and privileges of the other party - a guild, a city, an ecclesiastical order,

15 For genre, see D. Armitage, The Declaration of Independence. A Global History (Cambridge, MA: Harvard University Press, 2007), pp. 13-15. The latter quote is taken from D. Edelstein, 'Enlightenment Rights Talk', The Journal of Modern History 86 (2014), pp. 530-565, at p. 564 .

16 M. Gauchet, La révolution des droits de l'homme (Paris: Gallimard, 1989); L. Hunt, Inventing Human Rights: A History (New York: W.W. Norton, 2007).

17 J. Rakove, Declaring Rights. A Brief History with Documents (New York: Bedford, 1998), pp. $7^{-14}$. 
a group of nobles, a group of colonists - was essentially perceived to be the grant of a favour. The famous English 1689 Bill of Rights was a confirmation of existing rights, not the proclamation of the natural right of a people to institute a new government. The crucial difference between this older tradition and the late eighteenth-century American rights declarations was that the latter were no compacts with a ruler, but declarations of popular sovereignty. Even in France, where the king was only deposed in August 1792, one of the striking features of the text of the 1789 Declaration of the Rights of Man and Citizen is the categorical omission of the king.

The Constitutional Convention of Virginia, the largest, most populated, and wealthiest of the American colonies, was the first to proclaim a Declaration of Rights. Adopted on June 12, 1776 (three weeks prior to the Declaration of Independence), it declared that 'all men are by nature equally free and independent and have certain inherent rights [...] namely, the enjoyment of life and liberty, with the means of acquiring and possessing property, and pursuing and obtaining happiness and safety'. Not every American state constitution was preceded by a rights declaration, however, and not all rights declarations had their foundation in the universalistic notion of natural rights. ${ }^{18}$ Only Pennsylvania, Vermont, and New Hampshire appealed like Virginia to notions of natural equality and the natural rights of life and liberty, as would Massachusetts in 1780.

The Declaration of Rights contained in the constitution of Pennsylvania adopted in late September 1776 was the least complex and most democratic of all American state constitutions: it installed a unicameral assembly, omitted an executive veto, and held elections based on a wide franchise. It read 'That all men are born equally free and independent, and have certain natural, inherent and inalienable rights.' ${ }^{19}$ In yet another variation, the Massachusetts Declaration

18 It was not the case, as Annie Jourdan has asserted, that 'chaque État du Nouveau Monde ou presque a élaboré une constitution écrite, fondée sur les droits fondamentaux naturels et inaliénables'. Jourdan, La Révolution batave, p. 39. The two states of Connecticut and Rhode Island did not frame new constitutions but stuck to an amended version of their colonial charters; Georgia, New Jersey, New York, and South Carolina adopted constitutions in which individual rights were protected in the constitutional texts themselves. B. Schwartz, The Great Rights of Mankind: A History of the American Bill of Rights (Lanham, MD: Rowman \& Littlefield, 1992), pp. 67-81; W.P. Adams, The First American Constitutions. Republican Ideology and the Making of the State Constitutions in the Revolutionary Era, trans. R. Kimber (Chapel Hill, N.C.: The University of North Carolina Press, 1980). The point is that Dutchmen and Frenchmen who sympathized with the American independence movement were actually quite selective in what documents, constitutions, and rights declaration they translated and published. 
of $178 \mathrm{o} \mathrm{stated:} \mathrm{'All} \mathrm{men} \mathrm{are} \mathrm{born} \mathrm{free} \mathrm{and} \mathrm{equal,} \mathrm{and} \mathrm{have} \mathrm{certain} \mathrm{natural,} \mathrm{essen-}$ tial, and unalienable rights; among which may be reckoned the right of enjoying and defending their lives and liberties'.

It is important to qualify the nature and weight of the natural rights language in American state declarations. Numerous American revolutionaries considered the appeal to the natural rights of man as an ultimate ground to justify their declarations of independence and their revolution in general. But in determining the specific form and meaning of citizens' rights, liberties, duties, and obligations, American state declarations and constitutions, as well as subsequent legal statutes and jurisprudence, heavily drew and improved upon the tradition of English common law. Many articles of the 1791 Bill of Rights, too, were inspired by and formulated in the language of 'English liberties'. In this respect, the French 1789 Declaration of the Rights of Man and Citizen differed in important ways from its American counterparts. For example, criminal procedural rights occupy a marginal place in the French Declaration (this applies to the 1795 Holland Declaration too). Instead, the French Declaration refers more abstractly to natural rights and the preservation of those rights in society, and deals more extensively with the law as the expression of the general will. ${ }^{20}$ American state declarations and constitutions, then, were appealing not because of the legal intricacies, but because they coupled natural rights with the legitimacy of revolutionary action, popular sovereignty and representative government, thus envisioning a new model of citizenship.

\section{$2 \quad$ Converging Revolutionary Citizenship Ideals}

The revolutionary acts of American states declaring independence from the British Empire were welcomed enthusiastically by Dutch patriots. It seemed as if the newly independent American states had put into practice some of the more sweeping ideas they had read about in the works of political thinkers such as John Locke, Jean-Jacques Rousseau, Joseph Priestley, and Richard Price. The Dutch translation of Price's Observations on the Nature of civil Liberty, the Principles of Government, and the Justice and Policy of the War with America (1776), one of the most discussed pamphlets on the American Revolution in

by Benjamin Franklin. It abolished property qualifications for voting and holding office and extended full political citizenship to all white males over twenty-one who had lived in the state and had paid taxes for at least a year.

20 D. Edelstein, 'Early-Modern Rights Regimes: A Genealogy of Revolutionary Rights', Critical Analysis of Law 3 (2016), pp. 221-242; idem, On the Spirit of Rights (Chicago, Ill: Chicago University Press, 2019), pp. 166-193; Rakove, Declaring Rights. 
England at the time, was carried out by the Dutch Patriot leader Joan Derk van der Capellen tot den Pol. Several years later this recalcitrant nobleman from the province of Overijssel would author the explosive 1781 pamphlet Aan het volk van Nederland (To the People of The Netherlands) that would catalyse the Patriot Movement. In the preface to Price's pamphlet, Van der Capellen explained that his translation was meant to enable his fellow Dutch citizens to take lessons from the 'true grounds of freedom and citizen-government' as displayed in the American Revolution. ${ }^{21}$

Van der Capellen tot den Pol's translation sought to appeal to considerable sections of the Dutch population that had grown increasingly unsatisfied with the established order. By the early 1780 s, the Dutch press became outspokenly critical and hostile toward the alliance of oligarchic elites and stadholder William v of Orange. ${ }^{22}$ The devastating defeat against England in the fourth Anglo-Dutch Sea War (1780-1784) represented to many Dutchmen the ultimate proof of their republic's severe decline and its deeply corrupt political system. In various cities the opposition radicalized, as citizens began to organize in political societies and civic militias. They demanded a voice in the form of citizen councils and more transparent and strictly monitored forms of political representation and governance. Adopting the name of 'Patriots', the movement had a nation-wide appeal even though its strongholds were unevenly spread throughout the country. Their political reasoning remained by and large embedded within the familiar, decentralized framework of largely autonomous provinces. Until the mid-178os, they still mainly drew on historical arguments and traditional liberties, seeking to 'restore' their 'ancient constitution' - the 1579 Union of Utrecht (which was in fact a treaty of alliance) - to its former lustre.

It was in this context that Dutch Patriots began to take a great interest in the American state declarations and constitutions that traversed the Atlantic. Newspapers with a European reach such as Gazette de Leyde and Politique hollandaise reported extensively on the American Revolution and introduced extracts from American rights declarations to their readership. ${ }^{23}$ The first Dutch translation (from the French) of American constitutions, the Verzameling van de constitutiën der vereenigde onafhanglyke staaten van Amerika (Collection of Constitutions of the United Independent States of America) of 1781 prefaced

21 'Voorrede' in: R. Price, Aanmerkingen over den aart der burgerlyke vrijheid, over de gronden der regeering, en over de rechtveerdigheid en staatkunde van den oorlog met Amerika, trans. J.D. van der Capellen tot den Pol (Leiden: Herding, 1776), p. 4 [Dutch original: 'ware gronden der Vryheid en Burgerregeering te leren kennen'.].

22 Van Sas, De metamorfose van Nederland, pp. 173-221.

23 Jourdan, 'The Netherlands in the Constellation', p. 202. 
the collection suggesting that 'these fine papers of a purified popular government [...] will stand the test of time and make the world a happy place. ${ }^{24}$ In a dedication to Benjamin Franklin that preceded the main text, the constitutions were praised as 'the most splendid monuments of human reason [...] the purest government of the people that has ever existed. ${ }^{25}$

The Leiden-based Patriot François Adriaan van der Kemp, a close associate of Joan Derk van der Capellen tot den Pol, contributed to the dissemination of the example of American rights declarations and constitutions by publishing his Verzameling van stukken tot de dertien vereenigde Staeten van NoordAmerica (Collection of Articles on the Thirteen United States of North America). One of John Adams's closest friends during his diplomatic mission in the Dutch Republic, Van der Kemp in his introduction spoke highly of the 'citizen's unalienable rights', including the 'inherent right' of violent resistance that some American constitutions had declared. ${ }^{26}$ In his collection, he included the Massachusetts Declaration of Rights which asserted that the people are sovereign and that all magistrates, whether legislative, executive, or judiciary, are servants of the people.

The Massachusetts declaration and constitution were also approvingly cited by the Patriot, republican lawyer, and future revolutionary Rutger-Jan Schimmelpenninck in his 1785 dissertation Verhandeling over eene welingerigte Volksregeering (Treatise on a Well-Constituted Government of the People). Schimmelpenninck's treatise advocated a representative democracy, drawing, as so many Dutch patriots did at the time, on various sources, including Rousseau, Priestly, Price, and Hutcheson. Yet, on several occasions Schimmelpenninck felt it useful to highlight the similarities between his ideas and the Massachusetts constitution's articles on sovereignty, freedom of opinion, and manners of voting. At the end of his treatise, he maintained that a 'solid bulwark of freedom' and a 'durable form of government' can only be secured by prescribing certain 'regulations' and 'foundational rules', arguing that a government's deviation from these rules would constitute a crime. An 'excellent' example of such regulations and rules, Schimmelpenninck informed his readers on the treaty's very last page, was given by the drafters of the Massachusetts and Pennsylvania constitutions. The substantial differences between the

24 Verzameling van de constitutiën der vereenigde onafhanglijke staaten van Amerika, 2 vols. (Dordrecht: F. Wanner, 1781), p. 3. This collection was a translation of the 1778 Recueil des loix constitutives des colonies angloises, translated by a certain Mr. Régnier.

25 'Opdragt van den Franschen vertaaler aan den heere Dr. Benjamin Franklin', in: Verzameling van de constitutiën der vereenigde onafhanglijke staaten van Amerika, vol. 1.

26 F.A. van der Kemp, Verzameling van stukken tot de dertien vereenigde Staeten van NoordAmerica (Leiden: L. Herdingh, 1781), xi, xl. 
Massachusetts and Pennsylvania constitutions in terms of legislature, balance of powers, and franchise were completely disregarded by Schimmelpenninck. It indicates that the wide range of constitutional options offered by the American states did not prevent Dutch patriots, as well as French reformers, to consider them more broadly, as part of one revolutionary project that left several options open. ${ }^{27}$

By $1786-1787$, the political language of Dutch Patriots had become a mixture of militant urban republicanism, a defence of traditional privileges, as well as calls for popular sovereignty based on what were dubbed inalienable, and occasionally, 'natural' rights. ${ }^{28}$ Although the Patriot Movement was eventually crushed by the armies of king Frederick William II of Prussia who came to the aid of his sister Princess Wilhelmina (the wife of Stadholder William v), the experiment in the 'new world' remained a source of inspiration for former Dutch Patriots. The American Revolution, after all, was not without its success; it remained a sign of political progress and the possibility of change. The Patriot and future Batavian revolutionary Herman Hendrik Vitringa would later recall that it was during this period that 'the spirit of the age was progressing'. The 'political concepts' that defined this spirit, Vitringa maintained, were brought into vogue by 'the philosophers of these days'. But they were 'in no small part developed by the North-American spirit of freedom. ${ }^{29}$

This is also what the American Revolution came to represent in France: the embodiment of some of the bolder philosophical and political ideas circulating at the time, the putting into practice of political concepts, the sign of progress. During the 1780 , France witnessed an outburst of both travel reports as well as more general political-philosophical and sociocultural reflections on the United States. Some of these authors, among them Jacques-Pierre Brissot, Marie-Jean-Antoine Nicolas de Caritat, marquis de Condorcet, Philip Mazzei, Gabriel Bonnot de Mably, Pierre Samuel Dupont de Nemours, and François Jean de Beauvoir, marquis de Chastellux, were to assume leading roles in French revolutionary politics and constitutional committees the following years. ${ }^{30}$ This group of américanistes, as Durand Echeverria explained some

27 R.J. Schimmelpenninck, Verhandeling over eene wel ingerigte volksregeering (Leiden: F. de Does, 1785), pp. 83-84.

28 Klein, Patriots repulikanisme; I.L. Leeb, The Ideological Origins of the Batavian Revolution. History and Politics in the Dutch Republic 1747-1800 (The Hague: Nijhoff, 1973); Velema, Republicans, pp. 139-158.

29 H.H. Vitringa, Gedenkschrift van Herman Hendrik Vitringa, 4 vols. (Arnhem: Nijhoff 18571864), vol. 1, p. 100.

$30 \quad$ D. Lacorne, L'invention de la république. Le modèle américain (Paris: Hachette, 1991), pp. $77-84$. 
decades ago, were not always in agreement with each other on how to interpret American affairs, nor did they form a party; they rather tended to meet at particular venues. Yet, for all of them the new independent states on the other side of the Atlantic were objects of critical admiration and wonder, models of reform, and a world onto which they could project their ideals. ${ }^{31}$

The American state constitutions and declarations in France, too, incited extensive comments and debates. ${ }^{32}$ They were published with the support of Benjamin Franklin in Affaires de l'Angleterre et de l'Amérique, a journal dedicated to the British-American conflict that ran from 1776 to 1779 . They had also become available through the translations of the Duke of Rochefoucauld, whose Constitutions des treize États-Unis de l'Amérique appeared in 1783, again with the aid of Franklin. ${ }^{33}$ In particular Condorcet, the most outspoken exponent of French 1780 s américanisme, and one of the foremost political and constitutional thinkers of the French Revolution, was deeply inspired by the American Revolution. In his Influence de la Révolution d'Amérique sur l'Europe, published in 1786, he wrote:

[I]t is not enough for these rights to be written in the books of philosophers and in the hearts of men, ignorant or weak men must be able to read them in the example of a great people. America has given us this example. Its Declaration of Independence is a simple and sublime exposition of these rights, so sacred and so long forgotten. No nation has known them so well or preserved them with such perfect integrity [...] The example of a great people among whom the rights of man are respected is useful to all others despite differences in climate, manners, and constitution. It shows that these rights are everywhere the same. ${ }^{34}$

Condorcet fully subscribed to the need for a French declaration of rights and was deeply impressed by the constitution of Pennsylvania. In Idées sur le despotisme, a pamphlet that came out in 1789 , he explained:

The only way of preventing tyranny, that is to say, the violation of men's rights, is to bring all of these rights, together in a declaration, to promulgate them widely, clearly and in detail, to publish this declaration with

31 D. Echeverria, Mirage in the West. A History of the French Image of American Society to 1815 (New York: Octagon Books, 1966), pp. 39-78.

32 Echeverria, Mirage in the West, pp. 161-174.

33 Constitutions des Treize États-Unis de l'Amérique, trans. La Rochefoucauld (Paris: Pierre, 1783).

34 Condorcet, Writings on the United States, ed. and trans. G. Ansart (Philadelphia, PA: Pennsylvania State University Press. 2012), p. 25. 
great solemnity, and to embody in it [the principle] that the legislative power, in whatever form it takes, will never be able to pass a decree contradicting any of the articles. ${ }^{35}$

Praise for the form, content, and example of American state constitutions was also expressed in the popular Recherches historiques et politiques sur les ÉtatsUnis de l'Amérique Septentrionale, a history of the American Revolution by the Italian diplomat (and friend of Thomas Jefferson) Philip Mazzei, who resided in Paris at that time. Mazzei's publication, in which Jefferson was closely involved, and which was partly translated by Condorcet and his wife Sophie de Condorcet, reproduced the Virginia Declaration of Rights. Mazzei added that 'all states [...] adopted the same laws' and that 'the exceptions consisted only of too slight differences to be essential'. On the United States Mazzei remarked, after laying out the principles of popular sovereignty and the general right of every citizen to vote and being voted into office, that 'There is only one class of citizens. ${ }^{36} \mathrm{He}$ furthermore accentuated the natural and inalienable character of the rights as proclaimed in declarations, and stressed that the drafting of constitutions was to be done by a special convention, not by an ordinary legislature which ought to be forbidden from changing the constitution.

Enumerating the rights of citizens quite literally became a Dutch-French affair. Caught up in it, among others, was the French nobleman Honoré-Gabriel Riqueti, comte de Mirabeau (1749-1791), the future leading moderate revolutionary advocating a constitutional monarchy and one of the most famous orators of the early stages of the French Revolution. His 1788 pamphlet Aux Bataves sur le stathouderat was immediately translated into Dutch. It leaned heavily on the language of American state constitutions. Toward the end of his pamphlet Mirabeau added a (quite unsystematic) list of rights and recommendations, a 'déclaration des droits de tout people qui veut la liberté'. Mirabeau's declaration of 26 articles, which was surely intended to reach a broader public than just the 'Batavians', commenced by announcing that 'all men are born free and equal'. It further maintained that all magistrates must be held accountable

35 Condorcet, Idées sur le despotisme, in: CEuvres de Condorcet, ed. A. Condorcet O'Connor and F. Arago, 12 vols. (Paris: Firmin Didot Frères, 1847), vol. 9, pp. 147-173, at p. 165. Translation taken from: 'On Despotism', in: Political Writings, ed. S. Lukes and N. Urbinati (Cambridge: Cambridge University Press, 2012), p. 175. Cf. 'Recognition of these rights is the basis of all societies, the only bastion that citizens have against the unjust laws which their representatives might be tempted to pass'. In: Reflexions sur ce qui a été fait, et sur ce qui reste à faire, as cited in: D. Williams, Condorcet and Modernity (Cambridge: Cambridge University Press, 2004), p. 5 2.

36 P. Mazzei, Recherches historiques et politiques sur les États-Unis de L'Amérique Septentrionale (Paris: Froullé, 1788), pp. 166-168. 
for their conduct. The people have the 'indissoluble right' to 'reform, improve, and transform entirely' their own government. They furthermore have the right to elect, and to be elected as, public officials. The declaration also listed the rights of association, deliberation, and bearing arms; a right to a fair, competent, and independent judicial system, and press freedom; it finally contained a safeguard for private property and a verdict against privileges and hereditary titles. $^{37}$

For those who read Mazzei and Mirabeau the British-American colonies were no doubt still an 'example from afar' ('voorbeeld in de verte'), not only in distance, but also mentally. ${ }^{38}$ Dutch Patriots were no colonial subjects and were not fighting an increasingly authoritarian, constitutional-monarchist regime seated in a distant metropole. Unlike American colonists, they had been citizens of an independent republic for (de facto) almost two centuries. Noone could furthermore possibly deny the immense environmental and physical differences between the American states and the Dutch Republic. For French aristocrats and urban intelligentsia too, it was hard to imagine a society that was socially and culturally more in contrast with France, than North America. The picture of life in the North-American colonies that emerged in publications such as the expanded French edition of St. John de Crèvecœur's Lettres d'un cultivateur américain (carefully tailored to the expectations and taste of a French audience) was one of simplicity, frugality, and egalitarian social relations; of living an idyllic, independent, agricultural life, in harmony with nature. For readers of Rousseau this virtuous and simple farmer was a recognizable figure, but also a far cry from the court life, salons, and complex moeurs and sociabilité of French elite society. ${ }^{39}$ French and Dutch revolutionaries such as Mirabeau, Condorcet, Schimmelpenninck and Bosch never desired to simply copy the American examples. After all, declarations of rights

37 Mirabeau, Aux Bataves, sur le stadhouderat (Amsterdam: n.p., 1788). It was immediately translated as Aan de Batavieren, over het stadhouderschap (Antwerpen: P. Rymers, 1788).

38 'Example from afar' is the title of the most comprehensive historical account of Dutch perceptions of the American Revolution: J.W. Schulte Nordholt, Voorbeeld in de verte. De invloed van de Amerikaanse revolutie in Nederland (Baarn: In den Toren, 1979).

39 J. Hector St. John de Crèvecœur, Letters from an American Farmer: Describing certain Provincial Situations, Manners, and Customs, not generally known; and conveying some Idea of the Late and Present Interior Circumstances of the British Colonies of North America (London: T. Davies, 1782). A French translation appeared in 1785: Lettres d'un cultivateur américain (Maastricht: J.E. Dufour \& P. Roux, 1785). It was translated into Dutch in 1784: Brieven van eenen Amerikaenschen landman van Carlisle in Pennsijlvanien; geschreven aen eenen zijner vrienden in Engeland; behelzende den toestand, zeden, landbouw, en gewoonten der inwoonders van eenige der nu Vereenigde dertien gewesten van Noord Amerika, voor en in den nu geëindigden oorlog (Leiden: L. Herdingh, 1784). 
offered no full-fledged models of citizenship and American state constitutions displayed a variety of different definitions of citizenship. But they provided examples worth following; not in every detail, but on the level of general principles.

However great the perceived and real differences, the independent American states represented freedom, the progressing 'spirit of the age', and the successful application of 'political concepts' forged by philosophers, such as popular sovereignty and political freedom. This image of the American Revolution matched up well with the republican citizenship rhetoric that had taken shape in the preceding decades in the works of Jean-Jacques Rousseau, Dénis Diderot, Gabriel Bonnot de Mably, and Guillaume-Joseph Saige. Its natural rights language echoed the natural law discourse of the économistes (or physiocrats). ${ }^{40}$

For the Dutch, moreover, the struggle for independence of a confederacy of autonomous states against a foreign king reminded them of their own revolt against Philips II of Spain in the late sixteenth century. In his 1782 lyrical poem dedicated to the 'freedom proclamation of North America', the Dutch publisher and poet Adriaan Loosjes, for example, asked his fellow citizens to behold the free states of North America 'as a country, like yours, touched by the ray of liberty, and to see in their state and destiny your own image'. In Loosjes' estimation 'everyone recognizes the fortune of this State originating from American freedom:41 Joseph Mandrillon, an Amsterdam-based French banker, in his Spectateur américain of 1784 described 'the republic of the United States' as an 'immense space where liberty seems to have established its empire, where good manners appear to be respected, where the laws only have the force to preserve to man the rights which he holds by nature'. Mandrillon considered the laws of American states a product of 'this enlightened age', in contrast to the laws on the European continent that still seemed to stem from 'ancient and barbaric times. ${ }^{42}$ The French republican publicist Gabriel Bonnot de Mably,

40 Edelstein, 'Early-Modern Rights Regimes'. This is not to say there were no philosophical and theoretical differences between the American state declarations and constitutions and these French political thinkers, or between these thinkers.

41 A. Loosjes, Gedenkzuil: ter gelegenheid der vry-verklaaring van Noord-America (Amsterdam: Holtrop, 1782), p. 1 .

42 M.J.********* [J. Mandrillon], Spectateur américain ou remarques générales sur l'Amérique septentrionale et sur la République des Treize-Etats-Unis (Amsterdam: E. van Harrevelt, 1784), xi, p. 255. A second, revised edition of Mandrillon's Spectateur américain appeared in 1785 . 
even though he was rather critical and somewhat pessimistic about the future prospects of the thirteen American republics, felt no hesitation to declare that they had rediscovered the dignity of man and went on to draw from the sources of the most wise philosophy the humane principles by which they wish to govern themselves' 43

The urgency these writers felt to express their appreciation of, and commitment to, the American application of principles they until then had only marvelled at by reading philosophical treatises, was in part triggered by the bitter attacks on the American experiment. British antirevolutionary writere, Orangist publicists such as Adriaan Kluit and Laurens Pieter van der Spiegel, and French monarchical defenders of the status quo, such as the royalist journalist Jacques Mallet du Pan, portrayed the American Revolution as a dangerous and, ultimately, hopeless venture. ${ }^{44} \mathrm{~A}$ considerable stream of French reformers such as Trophime Gérard de Lally-Tollendal, Stanislas Clermont-Tonnerre, Chrétien de Malesherbes and Jean-Joseph Mounier were inclined to look at the English constitution for inspiration. They had a strong case for doing so in the light of Jean Louis De Lolme's powerful argumentative exposition Constitution de l'Angleterre and England's success and prosperity.

In their counteroffensive against this influential public opinion, French américanistes, and Dutch Patriots were assisted by leading American revolutionary politicians and publicists. Indeed, the shaping of an Atlantic revolutionary frame of mind and the convergence of the principles and ideals of constitutionalism, popular sovereignty, rights declarations, and equal citizenship, was to an important extent the result of the efforts of Benjamin Franklin, Thomas Paine, and Thomas Jefferson to forge an intellectual alliance with those in Europe who were sympathetic to their cause..$^{45}$ Certainly, diplomatic, financial and commercial interests were tremendously important in their endeavours to seek European allies. But the 'kindred spirit tie of congenial principles' that was forged in this process in the minds of Americans, Dutchmen, and Frenchmen was the intellectual foundation of what came to be considered as a larger revolutionary movement. The heart of the matter is that the American example was a promise, a promise of a comprehensive model of what popular sovereignty and citizenship in a constitutional, representative government might look like. The American state declarations and constitutions

43 G.B. de Mably, Observations sur le gouvernement et les loix des États-Unis (Amsterdam: Rosart, 1784), p. 2.

44 Schulte Nordholt, Voorbeeld in de verte, p. 119; Echeverria, Mirage in the West, pp. 128-129. See also F. Soulès, Histoire des troubles de l'Amérique anglaise (Paris: Buisson, 1787).

45 W.H. Adams, The Paris Years of Thomas Jefferson (New Haven, CT: Yale University Press, 1997); Newman and Onuf (eds.) Paine and Jefferson in the Age of Revolutions; Ziesche, Cosmopolitan Patriots. 
provided a summary of this model. The promise was that a great part of this model, if slightly amended according to national circumstances, could be introduced in France and the Dutch Republic too.

Ironically, by the end of the decade during which the American state declarations and constitutions became such an important example to (future) revolutionaries on the other side of the Atlantic, the Americans adopted a new constitution partly out of discontent with the workings of the state legislatures that were perceived as too democratic. ${ }^{46}$ American Federalists such as Alexander Hamilton desired a constitution to 'contain the amazing violence and turbulence of the democratic spirit'. Governor of Virginia and delegate to the Constitutional Convention Edmund Randolph equally imagined the new constitution to be 'a strong barrier against democracy'. The new American constitution that was debated in $1787-1788$ and ratified in June 1788 , moreover, neither defined citizenship, nor the duties and rights assigned to citizens, nor the relationship between state citizenship and national citizenship. 'From the perspective of citizenship', as Douglas Bradburn put it, 'the ratification of the U.S. Constitution cannot represent either a culmination or a beginning. ${ }^{47}$ The transformation of being a subject in a monarchical empire into an American citizen was not a product of the 1788 constitution, but of the revolutionary period and its founding documents: the Declaration of Independence, the revolutionary war, the state declarations and constitutions. By 1789, however, the French were too busy with their own revolution for the American constitution to have a huge impact on French constitutional thought. Dutch Patriots who had always been more familiar with France, and some of whom actually lived there in exile, became equally transfixed by the revolution that took place so much closer to home.

The French Revolution and the Heyday of a Transatlantic Ideal of Citizenship

To many Americans, Frenchmen, and Dutchmen the outbreak of the French Revolution provided an unmistakable confirmation of the new wind blowing in the Atlantic world. From an Atlantic perspective, the revolution in one of the most illustrious and powerful kingdoms of Europe suggested that their revolutions could be assembled under one banner and that one could commit

\footnotetext{
46 W. Holton, Unruly Americans and the Origins of the Constitution (New York, N.Y.: Hill and Wang, 2007); T. Bouton, Taming Democracy: 'The People', the Founders, and the Troubled Ending of the American Revolution (Oxford: Oxford University Press, 2007). 
to a common cause that transcended national boundaries. But the notion of a common revolutionary project did not appear out of nowhere; it was itself a product, a construction. 'The present era - THE ERA OF FREEDOM - OF UNIVERSAL LIBERTY in this Western world', the Gazette of the United States of July 7, 1789, announced, was one of 'liberality, enlightened policy, and superior wisdom'. The 'spirit' of the new era 'broke the chains which held mankind in servitude - and having fixed her temple in our favoured country, she is spreading her salutary reign throughout the world' ${ }^{48}$ The French translation of Observations of Government, an attack by the New-Jersey revolutionary and politician John Stevens on both De Lolme's and John Adams's defences of the English system of mixed government buttressed this vision. Edited and expanded with an additional 200 pages with notes by Condorcet and the économiste Pierre Samuel du Pont de Nemours it appeared on the eve of the convocation of the Estates General in early 1789. The editors pictured the supporters of this common cause as constituting an imaginative 'republic': 49

There is in the universe a great republic in which all studious and honourable men have the right of citizenship (droit de cité). Their vigorous army is recruited from all countries. She is the natural ally to all other republics and all empires in which people are devoted to the common good. She is the natural enemy of all those arbitrary and oppressive governments. She has this remarkable feature that her members, by attaching themselves to her, become still better citizens of their own fatherland. ${ }^{50}$

This passage shows that revolutionaries such as Condorcet and Dupont de Nemours put forth citizenship ideals operating on two levels. They evoked an imaginative Atlantic 'republic' of revolutionaries surrounded by enemies. But they by no means had in mind a model of universal citizenship for a 'real' world republic. They all stressed that citizens were tied to the nation (or fatherland), whether French, American, Dutch, or otherwise. Their point was that by joining the imagined 'republic' of Atlantic revolutionaries, one could become a

$48 \quad$ Gazette of the United States (Philadelphia, Pennsylvania), July 7, 1789.

49 John Stevens was born in a prominent New Jersey family. Madison sent his pamphlet to Philip Mazzei who passed it on to the circle of Condorcet and Du Pont de Nemours. According to Joyce Appleby, Jefferson played a role in publishing the heavily annotated French translation. J. Appleby, 'The Jefferson-Adams Rupture and the First French Translation of John Adams' 'Defence", American Historical Review 73 (1968), pp. 1084-1091.

50 J. Stevens, Examen du gouvernement d'Angleterre, comparé aux constitutions des États-Unis de l'Amérique, par un cultivateur de New-Jersey (Paris: Froullé, 1789), vii. 
better national citizen in one's own polity (whether it was a republic or a constitutional monarchy). They believed in a model of citizenship based on the national instantiation of similar, Atlantic-wide shared principles.

The most prominent and well-known citizen of this imaginative Atlantic 'republic' - and the one who did most to nurture and propagate it - was Thomas Paine. This Anglo-American political thinker and publicist born in Thetford, Norfolk, became the embodiment of the convergence of citizenship ideals in the Atlantic world. ${ }^{51}$ By some American newspapers he was referred to as the 'trans-Atlantic patriot'. ${ }^{52}$ His ground-breaking pamphlet Common Sense (1776) was by far the most read pamphlet of the entire American Revolution. ${ }^{53}$ In it he already anticipated his later universalistic rhetoric, claiming that 'The cause of American is in great measure the cause of all mankind. ${ }^{54}$ His Rights of Man (Part one), which came out in London in February 1791, was immediately translated into French. It was soon published in Paris and Baltimore. The second part, often bound together with the first, followed twelve months later. Paine dedicated his Rights of Man to the President of the United States, George Washington, "That the Rights of Man may become as universal as your benevolence can wish, and that you may enjoy the happiness of seeing the

$5^{1} \quad$ Paine has been paid significant attention lately by historians and political scientists alike. See among others, Cotlar, Tom Paine's America; J. Fruchtman Jr., The Political Philosophy of Thomas Paine (Baltimore, MD: Johns Hopkins University Press, 2009); R. Lamb, Thomas Paine and the Idea of Human Rights (Cambridge: Cambridge University Press, 2015); E. Maurice, Thomas Paine. Le combattant des deux revolutions, américaine et française (Paris: L'Harmattan, 2004); C. Nelson, Thomas Paine: Enlightenment, Revolution, and the Birth of Modern Nations (New York: Viking, 2006); M. Philp, Reforming Ideas in Britain: Politics and Language in the Shadow of the French Revolution, 1789-1815 (Cambridge: Cambridge University Press, 2014); S. Rosenfeld, Common Sense. A Political History (Cambridge, MA: Harvard University Press, 2014); B. Vincent, The Transatlantic Republic. Thomas Paine and the Age of Revolutions (Amsterdam: Rodopi, 2005).

$5^{2}$ Columbian Centinel (Boston, Massachusetts), June 8, 1791.

53 According to Philip S. Foner, more than 500,000 copies were sold, and parts of it appeared in numerous newspapers. Foner, 'Introduction', in idem (ed.), P.S. Foner (ed.), The Life and Major Writings of Thomas Paine (New York, N.Y.: Citadel Press, 1993 [1948]). Born in Thetford, Norfolk, in 1737, Thomas Paine spent the first half of his life in England. In late November 1774, on the eve of the American Revolution, he set foot in Philadelphia where he became a journalist and soon started to write essays for the Pennsylvania Magazine which attracted the attention of political radicals and members of the Second Continental Congress. At the request of Benjamin Rush, he started to write a pamphlet in late 1775 legitimizing the separation of the colonies from the British Empire which resulted in the most famous call for independence of the American Revolution.

54 T. Paine, Common Sense, in: Collected Writings, ed. E. Foner, (New York: Classic House, 2009), p. 5 . 
New World regenerate the Old. ${ }^{55}$ Deliberately situated in a transatlantic context, Rights of Man became the most successful and debated pamphlet of the early 1790s. The Dutch translation went through three editions between 1791 and 1793; it became essential reading within radicalized reading societies. In 1794, Common Sense also appeared in a Dutch translation, as well as most of his other writings of the $1790{ }^{56}{ }^{56}$ Paine was praised by Batavian revolutionary journals, and often approvingly referred to by Dutch politicians on the very floor of the Batavian National Assembly. ${ }^{57}$

In France, Paine was even a greater celebrity. According to Bernard Vincent, some 15,000 copies of Droits de l'homme were sold in the first three months after its publication. ${ }^{58}$ Paine had been a frequent visitor to Paris before the outbreak of the revolution and lived in France for most of the 1790s. In Paris, he was close with Jefferson and moved in the same circles. ${ }^{59}$ In the aftermath of the King's calamitous flight to Varennes in 1791, Paine, in association with

55 T. Paine, Rights of Man, in: Foner (ed.), The Life and Major Writings of Thomas Paine, p. 244. Alfred Young has counted 26 printings of Rights of Man in seven different American cities (of Part 1), 9 of Part 2 in six cities, as well as several combined printings. Numerous newspapers printed extracts of Rights of Man. Young makes an educated guess of a total sale of between 50,000 and 100,000 copies. A. Young, 'Common Sense and the Rights of Man in America. The Celebration and Damnation of Thomas Paine', in: K. Gavroglu, J. Stachel, M.W. Wartofsky (eds.) Science, Mind, and Art (Dordrecht: Kluwer Academic Publishers, 1995), pp. 411-439.

56 The three editions of Rechten van den mensch, of De aanval van den heer Burke op de Fransche omwenteling / beantwoord door Thomas Paine were published by two publishers in Amsterdam and Rotterdam (Meyer and Brongers). Paine's other translated writings include: T. Paine, Het gezond verstand (Dordrecht, n.p., 1794); Brief aan 't Fransche volk (Amsterdam: Brongers, 1792); Burgerpligt-leerende redevoering aan het volk / door Thomas Payne, en deszelfs gevoelen ... betreffende de gerechtelyke beoordeeling van Lodewyk den zestienden: met eene voorrede van den uitgever over de vryheid en gelykheid, en het recht van vry spreken en schryven, byzonder der Nederlanderen (Amsterdam: Brongers, 1794); De eeuw der rede. Zijnde eene nasporing van ware en fabelachtige godgeleerdheid (The Hague: Leeuwestyn, 1798).

57 De leerzame praat-al 2, no. 49 (December 7, 1791), pp. 385-392; Dagverhaal der handelingen van de Nationaale Vergadering representeerende het Volkvan Nederland; van de tweede Nationale Vergadering; van de Nationaale en Constitueerende Vergadering representeerende het Bataafsche volk, 9 vols. (The Hague: Van Schelle, 1796-1798), vol. 3, no. 264, November 28, 1796 (session November 21), p. 753 [Hereafter: Dagverhaal]; De democraten, 3 vols. (1796-1798), in numbers 11, 34, 48, 6o, 87; De republikein, vol. 2, no. 77, (1796), p. 199.

58 B. Vincent, The Transatlantic Republic. Thomas Paine and the Age of Revolutions (Amsterdam: Rodopi, 2005), p. 13.

59 M. Philp, 'Paine, Rights of Man', in: P. Clemit (ed.) The Cambridge Companion to British Literature of the French Revolution in the 179os (Cambridge: Cambridge University Press, 2011), pp. 31-46; M. Philp, 'Revolutionaries in Paris. Paine, Jefferson, and Democracy', in: Newman and Onuf (eds.) Paine and Jefferson in the Age of Revolutions, pp. 137-160. 
Condorcet, Brissot, and others, formed the first republican society, explicitly advocating a republican regime of government without a monarch. ${ }^{60} \mathrm{He}$ was accorded French citizenship (together with 17 other foreigners) after the fall of the monarchy in August 1792 and elected to the National Convention as a representative of Calais (three other departments had also nominated him). He soon joined the 'Committee of Nine' chaired by Condorcet in order to draft a new constitution for the Year I.

In his address to the French people upon accepting his nomination as national representative, printed in several American newspapers and translated into Dutch, Paine proclaimed 'the establishment of a new era, that shall blot despotism from the earth, and fix, on the lasting principles of peace and citizenship, the great Republic of Man'. Recalling his own role in the American Revolution, Paine told the French people that

The principles on which that Revolution began, have extended themselves to Europe; and an over-ruling Providence is regenerating the old world by the principles of the new. The distance of America from all the other parts of the globe, did not admit of her carrying those principles beyond her own situation. It is to the peculiar honor of France, that she now raises the standard of liberty for all nations; and in fighting her own battles, contends for the rights of all mankind. ${ }^{61}$

What made Paine's rhetoric so attractive, both to the French, Americans, and the Dutch, was that he used the same heading 'republic' to classify the American and French polities - that is to say, a 'true and free' republic. Neglecting many traditional ideas about the nature of a republic, he bluntly defined it as 'government by election and representation'.62 On several occasions he asserted that the Dutch, for instance, did not constitute a genuine republic in this sense. His point was that they could, indeed, become one. Such a true republic in which the people are sovereign, and their natural rights protected, requires a constitution. Several years later, Paine's definition of a constitution would be quoted approvingly in the Dutch National Assembly by the Republican representative Hendrik Midderich. On November 21, 1796, he referred to Paine as

6o Condorcet and Paine were close associates. Paine could often be found in the mansion of Nicolas and Sophie de Condorcet. Paine's 'Address to the people of France' was translated by Condorcet. Together they edited and contributed to the journal Le républicain.

61 The Mail; or, Claypoole's Daily Advertiser (Philadelphia, Pennsylvania), December 29, 1792.

62 T. Paine, 'To the People of France', in: idem, The Political Writings of Thomas Paine, 2 vols. (Charleston, S.C.: Davidson, 1824), vol. 2, p. 390. 
'one of the most honest and clever of Republicans, one of the most enlightened political philosophers':63

A constitution is a thing antecedent to government, and a government is only the creature of a constitution. The constitution of a country is not the act of its government, but of the people constituting a government.

It is the body of elements, to which you can refer and quote article by article; and which contains the principles upon which the government shall be established, the manner in which it shall be organized, the powers it shall have, the mode of elections, the duration of parliaments, or by what other name such bodies may be called; the powers which the executive part of the government shall have; and, in fine, every thing that relates to the complete organization of a civil government, and the principles upon which it shall act, and by which it shall be bound. ${ }^{64}$

This transatlantic rhetoric, in which constitution, rights, equal citizenship, and popular sovereignty were key concepts, presented the American and French revolutions as mutually invigorating each other. While the American Revolution had been an example to France, Paine explained that France was now carrying on the torch as demonstrated by the French Declarations of the Rights of Man and Citizen: 'the whole of the Declaration of Rights is of more value to the world, and will do more good, than all the laws and statutes that have yet been promulgated'.65 Together they had fundamentally changed the entire concept of revolution:

What were formerly called revolutions, were little more than a change of persons or an alteration of circumstances. [...] But what we now see in the world, from the revolutions of America and France, is a renovation of the natural order of things, a system of principles as universal as truth and the existence of man, and combining moral with political happiness and national prosperity. ${ }^{66}$

Paine, thus, firmly wedded the American and French revolutions within a single framework, while opening the club to other nations. At its core, the suggestion went, these revolutions shared a single set of principles underlying a revolutionary conception of citizenship that could be transplanted to the

63 Dagverhaal 3, no. 264, November 28, 1796 (session November 21), p. 753.

64 Paine, Rights of Man, p. 278. Cf. Anonymous [T. Paine], 'Four Letters on Interesting Subjects' (1776), in: Rakove, Declaring Rights, pp. 71-73.

65 Paine, Rights of Man, p. 316.

66 Paine, Rights of Man, pp. 341-342. 
rest of Europe. It was 'an age of revolutions, in which every thing may be looked for'.67

Former Dutch Patriots as well as those who had come of age in the early 1790 s eagerly embraced Paine's message. To the lawyer and publicist Pieter Paulus (1753-1796), one of the 'founding fathers' of the Batavian Revolution, both the American and French Revolution served as sources of inspiration. As one of the leading Batavian revolutionaries, Paulus chaired the revolutionary Holland Assembly of Provisional Representatives in 1795 and delivered the opening speech of the Nationale Vergadering (National Assembly) as its first chairman on March 1, 1796. His chairmanship lasted only 16 days, however, as he fell ill and died at the age of $42 .{ }^{68}$ Back in 1787 , he had visited Paris on a secret mission to discuss the Patriot cause with French officials and ministers, and possibly even convince them to support Patriots in their attempt to overthrow the stadholder. In Paris, he met Lafayette and Jefferson, frequented many dinners and salons, and was able to set up meetings with high French diplomats, one of whom called Paulus 'a very enlightened patriot'.69 Although his efforts were in vain, as the French at that time had more important domestic issue to attend to, between 1792 and 1796 Paulus together with his fellow Dutch revolutionaries could be seen as carrying on the torch of Atlantic revolutions.

Paulus's 1793 Verhandeling over de vrage: in welken zin kunnen de menschen gezegd worden gelyk te zyn? En welke zyn de regten en pligten die daaruit voordvloeien? (Treatise on the Question: In which Sense Can People be Said to be Equal? And which are the Rights and Duties that can be Said to Result from it?, hereafter: Treatise on Equality) was the single most important work of Batavian political thought. In it he argued on the assumption of the 'moral' equality of men in their natural condition (with reference to Locke's Second Treatise) for a 'burgermaatschappij' (citizen society) in which the natural rights of man must be maintained and protected. ${ }^{70}$ Critical of what he took to be Rousseau's

$67 \quad$ Paine, Rights of Man, 344 .

68 Surprisingly, there is no good biography of Paulus. In fact, the secondary literature is scarce, but see E. Van der Wal, 'Geen natie van atheïsten. Pieter Paulus (1753-1796) over godsdienst en mensenrechten',Jaarboek van de Maatschappij der Nederlandse Letterkunde te Leiden, 1995-1996 (Leiden: Brill, 1997), pp. 45-62.

69 A. Baggerman and R. Dekker, Kind van de toekomst. De wondere wereld van Otto van Eck (1780-1798) (Amsterdam: Wereldbibliotheek, 2005), pp. 30-31.

70 Paulus's treatise was his response to the prize essay contest on the question 'in which sense can people be said to be equal and which are the rights and duties that can be said to result from this equality?', proposed in 1791 by the Teylers Godgeleerd Genootschap (Teyler's Theological Society), one of the more prominent Dutch learned societies at the time. Paulus finished his treatise too late and was not intended to compete for the price which had already been won by the professor of natural law and law of nations at the Amsterdam 
mistaken view of the a-moral natural condition of solitary 'savages', he rejected an abrupt break between a state of nature in which man enjoys his natural rights, and a civil society in which merely 'positive' civil rights are protected. The burgermaatschappij in which people enter by voluntary consent, thus, ought to maintain the original moral equality and natural rights of men. By praising both Paine's Rights of Man and the French Declaration of the Rights of Man and Citizen, Paulus situated his Treatise on Equality in the context of Atlantic revolutions. Apart from drawing on Locke, Montesquieu, Price, Cicero, Burlamaqui, and others, Paulus also used a full 20 pages to argue that his conception of equality was entirely coherent with the teachings of Christianity, in particular with the lessons exemplified by Jesus's life as told in the four canonical gospels.

If one of the key political treatises of the Batavian Revolution consequently had its own Christian flavour, it was fully consistent with the broad model of a representative republic based on the principles of popular sovereignty, constitutionalism, equality before the law, and the unalienable rights of man. Its model of citizenship closely resembled that of political thinkers such as Paine or Condorcet. The Treatise on Equality was reprinted four times in a short period of time, translated into French, and was mentioned in French and American newspapers. ${ }^{71}$ The Holland Declaration of Rights of Man and Citizen of 1795, drafted principally by Paulus and the Leiden lawyer Jacob George Hieronimus Hahn took some phrases almost verbatim from Paulus's list of rights as enumerated in his Treatise on Equality. In turn, the Holland Declaration would serve as a direct inspiration for the 1798 Batavian Declaration of the Rights of Man and Citizen for the one and indivisible Batavian Republic.

Many Batavian revolutionaries, thus, saw themselves as taking part in a larger revolution. As the journal De republikein pointed out in 1796, after having outlined a constitutional representative republic based on the rights of man:

Athenaeum Illustre, Henrik Constanyn Cras's Verhandeling over de gelykheid der menschen, en de regten en pligten, welken uit die gelykheid voortvloeijen (Treatise on the Equality of Men and the Rights and Duties that Result from this Equality) (Haarlem: Enschedé \& van Walré, 1793). Paulus was familiar with Cras's essay, which was in the end completely overshadowed by Paulus's treatise.

71 An article reprinted and translated from the French Moniteur Universel stated: 'Paulinus, author of several valuable works upon the Rights of the People, who was bold enough to publish even in Holland, under his name two years ago, a Treatise on the Rights of Man, has just been elected grand pensioner of the regenerated states of Holland'. It also mentioned his visit in France in 1787-1788. This article appeared in: Gazette of the United States, April 3, 1795 (Philadelphia, Pennsylvania); Greenleaf's New York Journal and Patriotic Register (New York, New York), April 8, 1795, and Phoenix, May 2, 1795 (Dover, New Hampshire). 
'all our remarks are no other than those of MONTESQUIEU, ROUSSEAU, FRANKLIN, RAYNAL, PAINE, SIEYES, MOUNIER, CONDORCET, etc., names every friend of the people has only pronounced with esteem. ${ }^{72}$ Apparently, the Dutch author saw no fundamental tensions between these authors, and he did not expect his readers to think otherwise. It was of course hardly an original strategy to back up one's position by claiming that it was supported by an international list of great revolutionaries and thinkers. Yet, this remark exemplifies the assumption that both sides of the Atlantic were somehow united in a common revolutionary project.

As this chapter has demonstrated, Konijnenburg's journal was no exception. In a speech in the Jacobin Club delivered in July 1791, the French revolutionary Brissot claimed that 'The American Revolution gave birth to the French Revolution. ${ }^{73}$ Exemplary of the outbursts of transatlantic enthusiasm in the United States were the toasts drunk at the New York Tammany Society in late December 1792. During the early years of the existence of this Society (that had been founded three years earlier) both Federalists and Republicans could still gather 'in the indissoluble bonds of Patriotic Friendship'. As a number of newspapers reported, in one of its celebratory meetings the society toasted on the 'The Republic of France', 'The Citizen of the world, Thomas Paine', 'Universal Freedom', and 'May the union and examples of France and America enlighten and bless mankind'. The newspaper reporter present at the meeting delighted in the fact that 'mankind begin[s] to feel a universal fellowship and brotherhood', and that the 'shores of Europe and America illuminate each other. ${ }^{74}$ Certainly, the editor of De republikein, Brissot, and the members of the

72 De republikein, vol. 2, no. 77, (1796) p. 199.

73 J.-P. Brissot, 'Discours sur la question de savoir si le roi peut être jugé prononcé à l'assemblée des amis de la constitution dans la séance du 10 juillet 1791', in: F.V.A. Aulard, La Société des Jacobins; recueil de documents, 6 vols. (Paris: Jouaust, 1887-1897), vol. 2, p. 622 .

74 'St. Tammany Society Constitution', in: E.P. Kilroe, Saint Tammany and the Origin of the Society of Tammany, or Columbian Order in the City of New York (New York, N.Y.: M.B. Brown, 1913), p. 128; The Daily Advertiser (New York, New York), December 29, 1792; NewJersey Journal (Elizabethtown, New Jersey) December 29, 1792; Argus (Boston, Massachusetts), January 8, 1793. The reports in American newspapers of toasts celebrating France could be multiplied endlessly. On the printing of toasts as 'form of political communication', see J.L. Pasley, '1800 as a Revolution in Political Culture. Newspapers, Celebrations, Voting, and Democratization in the Early Republic', in: P.S. Onuf, J.E. Lewis, and J. Horn (eds.) The Revolution of 180o: Democracy, Race, and the New Republic (Charlottesville, VA: University Press of Virginia Press, 2002), pp. 121-152, esp. pp. 133-134. On the Tammany Society celebrating the French Revolution, see A.F. Young, The Democratic Republicans of New York: The Origins, 1763-1797 (Chapel Hill, N.C.: University of North Carolina Press, 1967), pp. 202-203, 208, 350. 
Tammany Society had their own reasons to invoke this common bond. But it was unmistakably a moment of converging ideals, principles, and a 'kindred spirit tie'.

\section{Regimes of Exclusion}

The upbeat, even militant transatlantic citizenship discourse, however, should not conceal the limits and concrete definitions of citizenship prevalent in the Atlantic world. Despite the universalistic tone of the revolutionary citizenship discourse in 1789 and the early 1790 s, in practice various social groups were excluded from citizenship, both in the American states, the later United States, France and the Dutch Republic. The converging citizenship ideals that were articulated in a universalistic language were themselves governed by various regimes of exclusion that were both evolving and politically divisive.

Historians of the age of Atlantic revolutions have thoroughly explored and debated the strategies and ideologies underpinning the exclusion - as well as (gradual) inclusion - of religious minorities, Jews, women, free men of colour, enslaved Africans, Native Indians, domestic servants, and the rural and urban poor. Various arguments, often (but as we will see, not always) specific to the group in question, were employed in order to reserve citizenship for a broadly defined group, i.e. the white, independent male, even though precise definitions differed and fluctuated. Jews, for example, were sometimes portrayed as a distinct 'people' within the state, Catholics as loyal to a 'foreign' authority, Native Indians as belonging to 'alien tribes' of an inferior civilization, and women as dependent and incapable of making informed judgments based on reason (the cases of free people of colour, and free and enslaved black people will be discussed extensively in Chapters $2-4) .75$

75 The literature is extensive, but see Olivier Le Cour Grandmaison, Les citoyennetés en Révolution: 1789-1794 (Paris: Presses Universitaires de France 1992); Rutjes, Door gelijkheid gegrepen, pp. 121-16o; Rogers M. Smith, Civic Ideals: Conflicting Visions of Citizenship in U.S. History (New Haven, CT: Yale University Press, 1997); Carroll Smith-Rosenberg, This Violent Empire: The Birth of an American National Identity (Chapel Hill, N.C.: University of North Carolina Press, 2010). More specifically on Jewish emancipation in the age of revolutions, see Rena Fuks-Mansveld, 'Verlichting en emancipatie omstreeks 1750-1813', in: Hans Blom (ed.) Geschiedenis van de Joden in Nederland (Amsterdam, 1995), pp. 177-203; Ronald Schechter, Obstinate Hebrews. Representations of Jews in France, 1715-1815 (Berkeley, CA: University of California Press, 2003), pp. 150-193. On women, their role in revolutionary political culture, and their exclusion from full citizenship, the literature is vast. Some of the more important works are: Susan Branson, These Fiery Frenchified Dames: Women and Political Culture in Early National Philadelphia (Philadelphia, PA: University of Pennsylvania Press, 2001);Jennifer Heuer, The Family and the Nation:Genderand Citizenship 
Yet the conferral of citizenship was not a zero-sum game. Several groups were admitted to the community of citizens broadly conceived. As members of the civic body they were granted a number of rights. Within the citizen body only a minority - usually white property-owning males - was entitled to a more elaborate set of rights, including the right of political participation, voting, and office. The crux of the matter for those groups whose claim to (fullfledged political) citizenship was contested, was that although their natural rights were generally recognized, full-fledged political citizenship required something else. ${ }^{76}$ As the French constitutional-monarchist and national representative the Duke of Larochefoucauld summarized in September 1791: ' $[\mathrm{P}]$ olitical capacity is not a natural right, but a right granted by society for its greater benefit' ${ }^{77}$ The phrase 'rights of man and citizen' as the French and Dutch declarations had it, was in that sense inherently unstable and potentially paradoxical. All citizens were entitled to the rights of man, but not all men (let alone women) were entitled to the rights of citizenship. The universalistic and egalitarian language of the rights of man was never intended for all members of the polity. Within the historical tradition of republican political thought at large, moreover, there was nothing unusual about distinguishing between man and citizen. Only independent males who owned a certain amount of property could claim full civil and political rights as citizens of the republic. True, in the second half of the eighteenth century the concept of republican citizenship evolved and merged with a popularized egalitarian language of natural rights. But throughout the Age of Revolutions and into the 179os, distinctions were made between claiming rights as human being, claiming (some) rights as member of the civic body, and claiming the full package of rights as political citizen. ${ }^{78}$

in Revolutionary France, 1789-1830 (Ithaca, N.Y.: Cornell Univesity Press, 2005); Evelien Koolhaas-Grosveld, 'Over vrouwen in de Bataafs-Franse Tijd', in: Grijzenhout, Van Sas and Velema (eds.) Het Bataafse experiment, pp. 185-213; Joan W. Scott, Only Paradoxes to offer: French Feminists and the Rights of Man (Cambridge, MA:Harvard University Press, 1996). On native Americans, see Frederick E. Hoxie, Ronald Hoffman, and Peter Albert (eds.) Native Americans and the Early Republic (Charlottesville, VA: University of Virginia Press, 1999); Colin Calloway, White People, Indians, and Highlanders. Tribal Peoples and Colonial Encounters in Scotland and America (Oxford: Oxford University Press, 2008); James Kettner, The Development of American Citizenship, pp. 287-333; Daniel R. Mandell, Tribe, Race, History. Native Americans in Southern New England, 1780-1880 (Baltimore, MD: Johns Hopkins University Press, 2010);Anthony F.C. Wallace,JeffersonandtheIndians:The TragicFateof the First Americans (Cambridge, MA:Harvard University Press, 1999).

$7^{6}$ The cases of free people of colour, and free and enslaved black people will be extensively discussed in Chapters 2-4.

$77 \quad A_{31}(24$ September 1791), pp. 282-283.

78 I'd like to thank Nathan Perl-Rosenthal for discussing this point with me. 
The limits of the natural rights one is entitled to (just by virtue of being human) was articulated by Condorcet, one of the most important natural rights theorists of the French Revolution, as well as a prominent antislavery spokesman and defender of women's rights. In various writings, including his famous Sketch for a Historical Picture of the Progress of the Human Mind, he made the unqualified statement that 'all men by their very nature possess equal rights.' ${ }^{9}$ However, despite his insistence on rights as man's natural attributes, the starting point for Condorcet's broader analysis of society was an 'enlightened citizenry'. 'In every civilized nation', Condorcet wrote in a series of anonymous letters in 1788 , 'there can be no enjoyment of natural rights without enlightenment. ${ }^{80}$ In his view, shared by many at time, there was an intimate link between the level of people's 'enlightenedness' and their entitlement to claim their rights as citizen.

There was also a political-economical dimension to it. The famous citizenship law adopted by the French National Constituent Assembly on 22 December 1789 , made a distinction between the 'passive' citizen as rights-holder and the 'active' citizen as politically-active agent. This distinction was first suggested by the abbé Sieyès who argued that 'only those who pay taxes are real stakeholders in the great social enterprise. They alone are true active citizens. ${ }^{81}$ The National Assembly adopted Sieyès's suggestion. It determined that to qualify for full active citizenship someone was required (1) to be a native or naturalized Frenchman; (2) to be over twenty-five years of age; (3) to pay a tax requirement equivalent to the local value of three days of labour; (4) to have resided in their own canton for at least a year; and (5) not to be deployed in domestic service. As Olivier Le Cour Grandmaison and others have argued, the formal tax requirement was grounded in the idea that eligibility for full active citizenship is dependent on possessing certain intellectual and moral qualities. These qualities in turn were dependent on financial independence and education. Only thus the citizen's public interestedness, autonomy, and sound judgement could be guaranteed..$^{82}$

79 Condorcet, Esquisse d'un tableau historique des progrès de l'esprit humain, in: CEuvres complètes de Condorcet, ed. A. Condorcet O'Connor and F. Arago, 12 vols. (Paris, 1847-49; repr. Stuttgart, 1968), vol. 6, p. 178.

$80 \quad$ As cited in: David Williams, Condorcet and Modernity (Cambridge: Cambridge University Press, 2004), p. 46, 51. The letters were published as Lettres d'un citoyen des États-Unis à un Français sur les affaires présentes (Philadelphia, PA, n.p., 1788).

81 Préliminaire de la Constitution françoise: reconnoissance et exposition raisonnée des droits de l'homme \& du citoyen (Versailles: Pierres, 1789), pp. 13-14.

82 Le Cour Grandmaison, Les citoyennetés en Révolution. Cf. Patrice Gueniffey, 'Suffrage', in: Furet and Ozouf (eds.), A Critical Dictionary of the French Revolution, pp. 571-581. The distinction was made famous, first, by the revolutionary thinker Emmanuel Joseph Sieyès. 
In practice, it meant that all women and around two-fifths of all adult French men were excluded from active citizenship. But in the early years of the French Revolution active citizenship too came in gradations: those active citizens eligible to vote (they were required to pay a tax minimum of three days' labour); those eligible to take municipal office or to be a member of the electoral colleges (a tax minimum of ten days' labour); and those eligible to serve as a national deputy (a tax minimum of one silver mark). 'Regular' active citizens, in other words, were only allowed to vote in primary assemblies for electors (the members of electoral assemblies); only electors voted directly for national deputies. As recent estimations point out, this meant that around sixty percent of all active citizens were eligible to take up municipal offices or become electors. ${ }^{83}$

The first French constitution promulgated on 14 September 1791 reiterated the distinction between active and passive citizens, raised the bar for electors (who elected national deputies), but revoked the silver mark as requirement for becoming a national representative. ${ }^{84}$ During the first year of the revolution the restrictions on active citizenship was, apart from a few isolated protests, not seriously challenged. But the silver mark requirement for national representatives caused public outcry from the start. From the left, journalists such as Camille Desmoulins and politicians such as Condorcet and Grégoire, but above all Maximilien Robespierre, were keen to point out the incongruence between the universalistic promise of the Declaration of the Rights of Man and Citizen and the restrictions placed on active citizenship, membership of the electoral assemblies, and the National Assembly. 85

The qualifications and restrictions of the French citizenship model of 1789-1791, however, did not prevent the Atlantic convergence of revolutionary citizenship ideals. In the early American Republic, the first stages of the

On this, see William H. Sewell, A Rhetoric of Bourgeois Revolution: The Abbé Sieyes and 'What Is the Third Estate?' (Durham, N.C., 1994), pp. 145-184.

83 Melvin Edelstein, The French Revolution and the Birth of Electoral Democracy (Farnham: Ashgate, 2014), pp. 67-68.

84 Varying according to the population of the city (or type of district) in question, only owners of property equivalent to a rental value of between 150- and 200-days' local wages (or tenants working a piece of land worth 400 days' wages in rent), were eligible to become elector and directly elect national deputies. Malcolm Crook, Elections in the French Revolution: An Apprenticeship in Democracy, 1789-1799 (Cambridge: Cambridge University Press, 1996), pp. 46-47. Patrice Gueniffey, Le Nombre et la raison. La Révolution française et les élections (Paris: Éditions de l'E.H.E.S.S., 1993).

85 Crook, Elections in the French Revolution, pp. 33-34; Edelstein, The French Revolution and the Birth of Electoral Democracy, pp. 47-48. 
French Revolution met with nearly universal approval across the entire political spectrum. ${ }^{86}$ The outbreak of the French Revolution and the Declaration of the Rights of Man and Citizen heralded the heyday of what many considered a new model of citizenship based on popular sovereignty, the rights of man, constitutional safeguards, and civil liberties, a model that seemed to have taken root on both sides of the Atlantic. As the following chapters point out, this transatlantic mind set would be severely tested in the years to come.

86 L.S. Kramer, 'The French Revolution and the Creation of American Political Culture', in: Klaits and Haltzel (eds.) The Global Ramifications of the French Revolution, pp. 26-54; Wood, Empire of Liberty, pp. 174-175; S.M. Elkins and E.L. McKitrick, The Age of Federalism (New York, N.Y.: Oxford University Press, 1993), pp. 309-310. 


\section{Saint-Domingue, Rights, and Empire}

Between 1789 and 1804 black slaves and free men of colour transformed the French plantation colony of Saint-Domingue into the independent state of Haiti. What initially began as an attempt of white French planters seeking representation in the newly summoned Estates General and wealthy so-called gens de couleur (free men of colour) demanding an end to racial discrimination, turned into a full-blown revolution when a massive slave insurrection broke out in the summer of 1791. A bloody civil war racked the island for more than a decade. With French, Spanish, and English armies invading the island and thousands of refugees fleeing to other Caribbean islands and North America, the revolutionary events in Saint-Domingue soon acquired international dimensions. News of the island's 'disaster' travelled far and wide. What was perhaps most amazing to observers at the time, apart from the reported scenes of violence and atrocities of civil war, was the interaction between metropolitan France and her colony's inhabitants. In 1792, after some hesitant and contradictory measures, the French Legislative Assembly granted free men of colour full citizenship; two years later, on February 4, 1794, the National Convention ratified the emancipation of slaves into citizens of the French Republic. Ten years later, despite Napoleon Bonaparte's attempt to re-establish control over the colony and restore slavery by sending a massive military expedition force, an army of black and coloured revolutionaries founded the first black independent state in America. ${ }^{1}$

The succession of revolutionary events that has come to be known as the Haitian Revolution sent shockwaves throughout the Atlantic world. In the

1 The last two decades have seen an explosion of publications on the Haitian Revolution. For recent overviews, see L. Dubois, Avengers of the New World: The Story of the Haitian Revolution (Cambridge, MA: Belknap Press of Harvard University Press, 2004); D.P. Geggus and N. Fiering (eds.), The World of the Haitian Revolution (Bloomington, IN: Indiana University Press, 2009); D.P. Geggus, The Haitian Revolution. A Documentary History (Indianapolis, IN: Hackett Publishing, 2014); J.D. Popkin, A Concise History of the Haitian Revolution (Malden, MA: WileyBlackwell, 2012). The classic account is C.L.R. James, The BlackJacobins. Toussaint L'Ouverture and the San Domingo Revolution (London: Penguin, 2001 [1938]). Important recent French studies on the French Revolution and the colonies include: F. Gauthier, Laristocratie de l'épiderme: Le combat de la Société des Citoyens de Couleur, 1789-1791 (Paris: CNRs Éditions, 2007); J. Piquet, L'émancipation des noirs dans la Révolution française: 1789-1795 (Paris: Karthala, 2002); F. Regent, Esclavage, métissage, liberté. La Révolution française en Guadeloupe (Paris: Grasset, 2004); C. Wanquet, La France et la première abolition de l'esclavage, 1794-1802: Le cas des colonies orientales, Île de France (Maurice) et La Réunion (Paris: Karthala, 1998).

(C) RENÉ KOEKKOEK, 2020 | DOI:10.1163/9789004416451_004

This is an open access chapter distributed under the terms of the CC BY-NC 4.olicensense keknoek - 978-90-04-41645-1 Downloaded from Brill.come4/26/2023 10:50:47AM 
course of events, as in its aftermath, the reactions to, and representations of the Haitian Revolution were diverse and ambiguous. The Haitian Revolution was, in the words of David Geggus, a combined outburst of 'free coloured activism, white settler autonomism, and slave resistance'. ${ }^{2}$ These various elements have come to function differently in different argumentative contexts. The following three chapters consist of a comparative analysis of the reactions to, and reflections on the different phases and events in Saint-Domingue in order to understand in what ways these responses came to inform conceptions of the limits of citizenship in France, the Dutch (Batavian) Republic and the United States. In what contexts and through what existing categories of thought were these disruptive events interpreted and explained at the time? In what kind of broader arguments concerning the nature and scope of citizenship did the Haitian Revolution come to play a role? And how did it affect the idea of a shared transatlantic revolutionary project of citizen emancipation?

Historians have rightly insisted that many aspects of the colonial revolutions in the Caribbean evolved from autonomous forces, that is, without France. The idea that there was an inevitable causal link between the 1789 Declaration of the Rights of Man and Citizen and the 1791 slave insurrection, or that the general emancipation degree of February 1794 was the unavoidable outcome of the slave insurrection has been forcefully challenged. ${ }^{3}$ Without doubt, both the insistence on causal factors independent of the metropole and the stress on the contingent nature of a number of crucial episodes have sharpened our grasp of the origins and nature of the Haitian Revolution and the contexts in which it took place. ${ }^{4}$ They are helpful reminders that the view of a francocentric unfolding of a universal rights project rooted in Enlightenment or 'radical' Enlightenment thought is overly simplistic. ${ }^{5}$

Yet it is at the same time crucial not to let the modern historian's perspective obscure our view of how contemporary observers perceived and interpreted the context and causal links between the French Revolution and the events in

2 D.P. Geggus, 'Saint Domingue on the Eve of Revolution', in: Geggus and Fiering (eds.) The World of the Haitian Revolution, pp. 3-20, at p. 14.

3 Popkin, You are all Free. Cf. D. Geggus, 'Rights, Resistance and Emancipation: A Response to Robin Blackburn', in: K.E. Tunstall (ed.) Self-Evident Truths? Human Rights and the Enlightenment (New York: Bloomsbury, 2012), pp. 157-167.

4 In particular James, The BlackJacobins; Césaire, Toussaint Louverture; Dubois, Avengers of the New World. Cf. D.P. Geggus, 'Racial Equality, Slavery, and Colonial Secession during the Constituent Assembly', American Historical Review 94 (1989), pp. 1290-1308, p. 1304.

5 The main representative of such views is probably N. Nesbitt, Universal Emancipation: The Haitian Revolution and the Radical Enlightenment (Charlottesville, VA: University of Virginia Press, 2008). For criticisms, see: D.P. Geggus, [review] N. Nisbett, 'Universal Emancipation: The Haitian Revolution and the Radical Enlightenment', American Historical Review 114 (2009), pp. 1501-1502. 
Saint-Domingue. Many commentators at the time perceived a direct link between the revolutionary decrees coming from the metropole and the unfolding catastrophic events in the French colony. The supposed causal link between French philosophical radicalism and the eruption of violence on SaintDomingue was widely established and articulated. What is striking, moreover, is that many of these writings did not pay any attention to the fact that the decision made in late 1793 by the leader of the Second Civil Commission to Saint-Domingue, Léger Félicité Sonthonax, to offer black slaves citizenship, was actually made under the severe pressure of the prospect of a military defeat against the British colonial armies. Few noticed that the French National Convention's ratification of February 4, 1794, was actually a confirmation of an established fact on the (Saint-Dominguan) ground. Finally, the anarchy, devastation, and horrors were often imputed to the French 1794 decision to abolish slavery, without seriously paying attention to the fact that a civil war had been going on since 1791. As a consequence, explanations for the catastrophic course of events in Saint-Domingue were more often than not reduced to a typical French zeal for radical egalitarian principles and their 'mistaken' application.

Various groups in the revolutionary Atlantic world welcomed or were (eventually) willing to defend the Saint-Domingue slave insurrection: enslaved and free blacks in the United States and the Caribbean, radical democraticrepublicans in the Batavian Republic, a number of (white) abolitionist activists in the United States, and some (but by no means all) radical Jacobins in revolutionary France. These groups were few, however, small in size, and hardly organized. Almost none supported the idea of immediate emancipation.

The majority of American, Dutch, and French revolutionaries, politicians, journalists, and publicists who reflected upon the events on Saint-Domingue expressed their views on citizenship on two levels. On the one hand, they qualified the nature and scope of citizenship in terms of the alleged backward level of civilization of black slaves. Here we can see striking commonalities between American, Dutch, and French evaluations of the Haitian Revolution, and parallel justifications of the limitations that were placed on the scope of citizenship. This civilizational qualification of citizenship led some to propose a status of 'second class' citizenship (although this specific term was not used). Various educational 'regeneration' programs - with varying time spans - were designed and aimed at educating and enlightening what they thought were 'infantile' savages. Others suggested more permanent schemes of civilizational inequality and civic exclusion. In either case, Saint-Domingue was invoked as the decisive proof that black slaves were insufficiently enlightened and civilized to be emancipated into citizens.

On the other hand, the French wavering and sometimes contradictory policies toward Saint-Domingue, in particular the decision to attribute to former 
black slaves citizenship rights in 1794, was widely seen as a dangerous philosophical experiment, as evidence that the French Revolution had careered off track. The French decree of immediate emancipation incited many Dutchmen and Americans, as well as more conservative Frenchmen around 180o, to disassociate themselves from French 'universalistic' understandings of citizenship that were considered dangerously naïve and utopian. The Haitian Revolution, thus, prompted people on both sides of the Atlantic to (re-)articulate the limits of their models of citizenship and disassociate themselves from an Atlantic citizenship discourse once shared. The Haitian Revolution, as it was seen through the lens of the civic policies of revolutionary France led to a divergence of citizenship discourses in the Atlantic world.

The following chapters will analyse this process in three phases. Focusing on the period between roughly mid-1789 to the summer of 1791 , this chapter shows how the question of equal citizenship within the framework of a colonial empire and beyond colour lines was put on the revolutionary agenda. This was by no means self-evident. The issue of civic equality and representation was raised first by French white planters. The claims of free people of colour both on the island and in France for equal rights and citizenship raised the stakes dramatically, especially when prominent revolutionaries of the Société des Amis des Noirs joined their ranks. They invoked the revolutionary 'logic' of the declarations of the rights of man and equal citizenship and applied it to the realm of the colonial empire. As both supporters and opponents of the claims by free people of colour understood, the situation on Saint-Domingue was now indissolubly related to wider debates about the ideals of the age of revolution, the constitutional unity of the empire, and the new revolutionary principles underlying citizenship. Chapter 3 goes on to show how the picture of SaintDomingue drastically altered between the outbreak of the slave insurrection in August 1791 and the French National Convention's emancipation decree of February 1794. It focuses on the articulation of imperial civic hierarchies based on the insurrectionists' alleged level of civilization. Chapter 4 shows how in the second half of the 1790 s the French imperial policies regarding Saint-Domingue became synonymous with what was considered a dangerous form of Jacobin universalism, a 'French' revolutionary radicalism that had gone astray.

The Haitian Revolution forced Americans, Dutch and French revolutionaries to reflect anew on the scope of revolutionary citizenship and the core, often implicit, assumptions underlying it. As Lynn Hunt has recently pointed out, the 'act' of declaring the rights of man, either in the 1776 American Declaration 
of Independence, the 1789 French Déclaration des droits de l'homme et du citoyen, or the 1795 Dutch Verklaring der rechten van den mensch en den burger brought about a certain 'inner logic'. Once the universal rights of humanity were declared, so the reasoning behind this logic goes, 'the floodgates were open': religious minorities, free people of colour, Jews, women, all could now claim equal rights on the basis of their membership of the party of humanity. ${ }^{6}$ The generality of the declarations' wordings - 'man', 'humanity', 'citizen' - 'exceeded the act of its enunciation', as Étienne Balibar has put it. ${ }^{7}$ It provoked radical interpretations of equality that the original drafters might not have imagined and most of them did not conceive at all. ${ }^{8}$ In contrast to Hunt, however, I prefer to speak of 'rights of man' instead of 'human rights' (as most eighteenth-century authors themselves actually did). Late eighteenth-century rights declarations were not intended to trump the ultimate authority and territorial integrity of the nation-state, as in modern human rights discourse, but rather to serve as its foundation by proclaiming the sovereignty of a distinct people. ${ }^{9}$ The rights of man only acquired meaning in a constituted political space. A key issue for colonial empires such as France and the Dutch Republic was how to define and demarcate 'the people' within what Gary Wilder has called an 'imperial nation-state.' ${ }^{0}$

Moreover, as Samuel Moyn has argued, there are reasons to be sceptical about how exactly the mechanism of the 'universalization' of rights works, since ascribing a universal logic to rights seems to presuppose that rights are necessarily univeralizable independent of human agency. ${ }^{11}$ In my view, it would be more accurate to qualify the notion of 'inner logic': rights declarations brought about an awareness of the argumentative or conceptual force of the potentially universal logic of rights declarations that, after all, were written in a highly universalistic language.

6 Hunt, Inventing Human Rights, pp. 146-176, esp. pp. 148-153.

7 E. Balibar, 'Citizen Subject', in: E. Cadava, P. Connor, and J. Nancy (eds.) Who Comes After the Subject? (London: Routledge, 1991), pp. 33-57, at p. $5^{2}$.

8 A.G. Sepinwall, The Abbé Grégoire and the French Revolution. The Making of Modern Universalism (Berkeley, CA: University of California Press, 2005), pp. 90-91; K.M. Baker, 'The Idea of a Declaration of Rights', in: D. van Kley (ed.) The French Idea of Freedom. The Old Regime and the Declaration of Rights of 1789 (Stanford, CA: Stanford University Press, 1994), pp. 154-196, at pp. 156-157, 191; M. Gauchet, 'Rights of Man', in: Ozouf and Furet (eds.) A Critical Dictionary of the French Revolution, pp. 818-828.

9 Cf. S. Moyn, The Last Utopia: Human Rights in History (Cambridge, MA: Belknap Press of Harvard University Press, 2010). See however, Edelstein, 'Enlightenment Rights Talk'.

10 Wilder, The French Imperial Nation-State.

11 S. Moyn, 'On the Nonglobalization of Ideas', in: S. Moyn and A. Sartori (eds.) Global Intellectual History (New York, N.Y.: Columbia University Press, 2013), pp. 187-204. 
Illustrative of the awareness of this logic - and the subsequent reticence on the part of many revolutionaries to face the potentially radical implications of the universalistic logic of rights declarations - is the often-reprinted series of articles 'The Rights of Black Men' by the Connecticut republican publicist Abraham Bishop. In September 1791, he deliberately invoked American revolutionary language so as to cast a sympathetic light on the slave revolt in SaintDomingue. He urged his readership to recognize that Saint-Dominguan blacks were fighting 'a cause like ours'. Hence, he commended, '[l]et us be consistent Americans'. A radical follower of Thomas Paine, Bishop reckoned that this 'seems to be the moment for the liberating societies in Europe and America to come forward, and to shew the sincerity of their professions, and their unwavering attachment to the Rights of Man'. His assertion that Saint-Dominguan slaves are 'entitled to freedom' was 'founded on the American Declaration of Independence $[\ldots]$ for we did not say, all white men are free, but all men are free.'12

That the claims of particular groups were seen as following a more general logic can also be observed in a lengthy pamphlet published in 1792 entitled Régénération des colonies by the lawyer, judge, member of the Société des Amis des Noirs, and future member of the National Convention and deputy of the Council of Five Hundred, Antoine-Jean-Thomas Bonnemain. In defence of the decree of April 4, 1792, that ensured civil and political equality to free people of colour, Bonnemain suggested that this decree 'should be considered like those regarding the Protestants and the Jews, decrees that are [...] a consequence of the natural and civil rights of man, guaranteed by the constitution.'. ${ }^{13}$ Another five years later, the remarks put forth by the Dutch representative Herman Hendrik Vitringa in the National Assembly of the Batavian Republic in the spring of 1797 conveyed a similar way of reasoning. During a series of debates

12 'The Rights of Black Men' appeared for the first time in Columbian Centinel (Boston, Massachusetts), September 21, 1791. It was reprinted in The Argus (Boston, Massachusetts), November 22, 25, December 2, 1791; Cumberland Gazette (Falmouth, Massachusetts), December 5 and 12, 1791; Federal Gazette (Philadelphia, Pennsylvania), December 3, 7, 17, 1791, American Museum (magazine), November 12, 1792, and National Gazette (Philadelphia, Pennsylvania), July 31, 1793. See T. Matthewson, 'Abraham Bishop, "The Rights of Black Men”, and the American Reaction to the Haitian Revolution', The Journal of Negro History 67 (1982), pp. 148-154; Cotlar, Tom Paine's America, pp. 58-59; M.A. Grossbart, 'Abraham Bishop: Teacher, Lawyer, Orator, and Politician', in: M.A. Morrison (ed.) The Human Tradition in Antebellum America (Lanham, MD: Rowman \& Littlefield, 200o), pp. 1-18; White, Encountering Revolution, p. 137. Quotes are taken from: Matthewson, 'Abraham Bishop', pp. $150-153$.

13 A.-J.-T. Bonnemain, Régénération des colonies, ou moyens de restituer graduellement aux hommes leur état politique et d'assurer la prospérité des nations (Paris: Imprimerie du Cercle Social, 1792), p. 101. 
over the question whether a new constitution should decree the abolition of slavery and the slave trade, Vitringa contemplated that because of the proclamation's 'abstract principles [...] we are no longer able to give or take from the eternal right of nature.' 'It could very well happen', he asserted, implicitly but obviously referring to Saint-Domingue, that 'only afterwards one comprehends the dangerous implications or the inapplicability' of such general principles. ${ }^{14}$

Regardless of the question whether and how many Atlantic revolutionaries actually subscribed to universalistic readings of declarations of rights of man, the remarks of these politicians and publicists demonstrate that on both sides of the Atlantic there was an awareness and public recognition of the argumentative or conceptual force of the logic of universalistic rights declarations. What this logic and the claims that drew upon it also generated, however, was the mobilization and sophistication of an arsenal of concepts, arguments, and theories to postpone, circumvent or simply refute this logic. The international reactions to the Haitian Revolution represent a pivotal moment in this process. It incited the articulation of deeply rooted assumptions about the prerequisites and capacities individuals needed in order to be admitted to the political community of citizens.

\section{The Nation's Colonial Citizens}

Soon upon hearing rumours of Louis XVI convoking the Estates General in 1787-1788, French white planters in Saint-Domingue illegally established electoral committees in order to delegate representatives to the general meeting of the realm's estates, which by the time they arrived had turned into the National Assembly. The French overseas colonial empire of the second half of the eighteenth century was an empire in decline, but Saint-Domingue was booming. France's loss of the Seven Year's War of $175^{6-1763}$ against the British had severely reduced her overseas possessions. The French were forced to renounce all their claims to Canada and had lost all but a handful of small plantation colonies and trading posts in the Indian Ocean. Their only and most lucrative remaining colonies were those in the Caribbean, Saint-Domingue standing out as the 'jewel in the crown'. ${ }^{15}$

14 Dagverhaal 5, no. 493, 28 April 1797 (session April 22), pp. 731-732; Dagverhaal 6, no. 549, 3 June 1797 (session May 22), p. 17. Vitringa was a member of the commission chaired by Jacob Hendrik Floh ('Floh commission') instituted by the Batavian National Assembly to give advice about the section on colonies in the future Batavian constitution.

15 The islands in the Indian Ocean were Île-de-France (now Mauritius) and Île Bourbon (now La Réunion), both near the east coast of Madagascar. 
Saint-Domingue was nothing less than a goldmine for the French colonial economy. More sugar came from Saint-Domingue than from all English colonies combined. The capital Cap Français, a city with more inhabitants than Philadelphia, was a burgeoning city with a Société royale des sciences et arts, literary societies and reading rooms, markets, bathhouses, theatres, and botanical gardens. It was a crucial nub in Caribbean trade networks. French overseas trade with Saint-Domingue comprised one-third of France's overall colonial economy. The sugar and coffee production of Saint-Domingue made up 40 and 60 percent of Europe's total consumption, respectively. SaintDomingue, in short, was of major commercial interest to France, especially to major port cities such as Bordeaux, Nantes, Marseilles, and Le Havre whose economies thrived on colonial trade.

On the eve of the French Revolution, both the ruling plantation class in Saint-Domingue and colonial landowners residing in France had their complaints about the French monarchy's imperial policy. Wealthy French planters and merchants living in Saint-Domingue decried the mercantilist restrictions imposed by the Colonial Ministry in Paris, and, moreover, resented the 17841785 royal decrees to ameliorate the condition of plantation slaves. ${ }^{16}$ Poor whites who did not belong to the wealthy planter class - among them plantation employees, seamen, artisans, guards, shopkeepers, sometimes called petit blancs - also had their grievances; against rich planters for not allowing them to set up their own plantations and share in their wealth; against the colony's royal government for reasons similar to those of the wealthy planter class; and in particular against wealthy free people of colour, several hundreds of families of whom owned slave plantations themselves, and whose social standing aroused a mixture of frustration, racial prejudice and envy. ${ }^{17}$ Finally, 'absent' plantation owners living in France, although supportive of more laissez-faire trade laws, feared that granting too much autonomy to the colonists might be harmful to their interests. American independence had set an unprecedented and forceful example of what conflicts of interests between metropole and colony could ultimately lead to. For many Frenchmen, the anti-imperial American Revolution was still fresh on their mind.

Not surprisingly, revolutionary white Saint-Dominguans reminded Americans of their own revolution too. A striking account of the early revolutionary

16 L. Dubois and J.D. Garrigus, Slave Revolution in the Caribbean, 1789-1804: A Brief History with Documents (Basingstoke: Palgrave Macmillan, 2006), pp. 16-19; M.W. Ghachem, The Old Regime and the Haitian Revolution (Cambridge: Cambridge University Press, 2012), pp. $156-166$.

17 Dubois and Garrigus, Slave Revolution in the Caribbean, pp. 20-21; Geggus, 'Saint Domingue on the Eve of Revolution', pp. 12-13; James, The Black Jacobins, p. 27. 
spirit among radicalized white settlers in light of the spectre of colonial independence can be found in the observations of Nathaniel Cutting (d. 1822). A New England businessman, slave trader as well as U.S. consul in Cap Français, Cutting wrote a number of letters from Saint-Domingue to his good acquaintance Thomas Jefferson, then US Secretary of State. ${ }^{18}$ In a letter dated 6 July 1790 from St. Marc, a west-coast town where radical whites had formed a colonial assembly, Cutting welcomed what he saw as the sudden and unexpected emancipation of French colonists 'from the galling fetters of a despotic Government'. ${ }^{19}$ Coming from the French seaport Le Havre where Cutting had lived and worked for three years between 1786 and the late summer of 1789 , he immediately related the turmoil in Saint-Domingue to the revolutionary happenings he had witnessed in Paris. Born and raised in revolutionary Massachusetts, Cutting was, thus, in the unique position to have personally witnessed three late eighteenth-century revolutions. Like most of his fellow Americans who, irrespective of their political colour, had delighted in the outbreak and early phase of the revolution on the other side of the Atlantic, Cutting rejoiced at the idea that the French Revolution, as he put it, 'may date its conception' from 'the late glorious struggle for Liberty' in America. ${ }^{20}$ 'Soon after the Commencement of the late Revolution in France', Cutting reported to Jefferson, 'the French Inhabitants of this Island became sensible of their consequence and determin'd to assert the natural rights of men'. Although weary of the 'Anarchy' that already had begun to 'unfurl her hateful Banner' as a consequence of the French colonists' differences in 'Political Sentiments', Cutting seemed to recognize their 'patriotic motive of securing to the Inhabitants of this Colony and their Posterity the blessings of a liberal constitution. ${ }^{21}$ Encouraged by Jefferson's assurance that the State Department relied heavily on the information contained in his letters which were regularly communicated to President Washington, Cutting even pictured to Jefferson a future in which the colony

18 For biographical information on Cutting, see Mr. Frothingham and Dr. Ellis, 'Extracts from Diary of Nathaniel Cutting', Proceedings of the Massachusetts Historical Society 12 (18711873), pp. 57-67, p. 6 o.

19 Nathaniel Cutting to Thomas Jefferson, 6 July 1790, The Papers of Thomas Jefferson Digital Edition, ed. B.B. Oberg and J.J. Looney (Charlottesville, VA: University of Virginia Press, Rotunda, 2008), http://rotunda.upress.virginia.edu/founders/TSJN-01-17-02-0002 (accessed 13 Nov 2012) [hereafter: $P T J$ ].

20 Nathaniel Cutting to Harrison Gray Otis, August 1789, Letterbook I, p. 71, in: Nathaniel Cutting Papers, Massachusetts Historical Society, as cited in: S.P. Newman, 'American Political Culture and the French and Haitian Revolutions. Nathaniel Cutting and the Jeffersonian Republicans', in: D.P. Geggus (ed.) The Impact of the Haitian Revolution in the Atlantic World (Columbia, S.C.: University of South Carolina Press, 2001), pp. 72-89, at p. 74. Cutting to Jefferson, 6 July 1790, PTJ; Cutting to Jefferson, 4 August 1790, PTJ. 
of Saint-Domingue 'may possibly fall within the Jurisdiction of the Thirteen United States' or at least 'will mutually invigorate those principles of Constitutional Freedom which have apparently taken such deep root in both Countries.'.22

Cutting's initial exultation about the prospect of a second independent New World republic in the Summer of 1790 was, however, rather optimistic at the time. A considerable part of the Saint-Dominguan plantations was owned by planters who had their permanent residence in France and were obviously not in favour of the colony's secession. For most white colonists residing in SaintDomingue who longed for more autonomy and self-governance, outright secession was not particularly desirable either, as they were being outnumbered by the slave population by 1 to 17 . They would have to invoke the support of French troops in case of an emergency, not to mention the danger of foreign invasion in a Caribbean environment occupied by increasingly hostile imperial powers. It was only from early 1791 onwards that threats of independence became more outspoken and widespread. ${ }^{23}$

Although Cutting's cautious suggestion of a second colonial revolution in the America's may not be surprising from an American perspective, revolutionary Saint-Domingue of $1789-90$ differed in at least one crucial aspect from the revolutionary American colonies of the 1770s: whereas Americans equated revolution with colonial independence, now the imperial motherland itself was undergoing a revolution. Revolutionary Saint-Domingue questioned and destabilized the limits of the sovereignty of the revolutionary French state, especially since the Declaration of the Rights of Man and Citizen had relocated this sovereignty within the nation. Whereas the American Revolution had established a close link between consent, citizenship and national selfdetermination, creating outside the boundaries of the British Empire a new polity on the basis of the - at least in theory - voluntary consent of its citizens, this spectre of colonial secession and its impact on the reconfiguration of the notion of citizenship within a 'republican empire' would work out differently in the case of French Saint-Domingue, and eventually the Dutch colonies. ${ }^{24}$ The French and Dutch 'imperial revolutions' did not imply a shift from overseas empire to nation-state. It involved, as Jeremy Adelman has argued, 'the exploration of models of re-accommodating colonies into imperial formations $[\ldots]$ that would stabilize, not dissolve, regimes. ${ }^{25}$

\footnotetext{
22 Jefferson to Cutting, 26 November 1790, PTJ; Cutting to Jefferson, 19 April 1791, PTJ.

23 Dubois, Avengers of the New World, pp. 89-90.

24 Kettner, The Development of American Citizenship, pp. 173-209.

25 Adelman, 'An Age of Imperial Revolutions', p. 332.
} 
Ironically, Saint-Dominguan planters partially called down catastrophe on themselves. By claiming to be part of the nation, and thus being entitled to representation in the metropole, they (perhaps unintentionally) raised the question of the constitutional unity of the French empire. As soon as the delegation of representatives of white Saint-Dominguan planters arrived in Paris and requested admission to the Estates General, their status became fiercely contested. In 1789, the island's population consisted of about 30,000 whites, 25,000 to 30,000 free people of colour, and around 500,000 black slaves of whom up to two-thirds were born in Africa. The colonial representatives requested a number of seats in the Estates General in proportion to the colony's entire population, but in late June and early July 1789 this request was criticized, most resolutely by the leading revolutionary Honoré Gabriel Riqueti, comte de Mirabeau. 'Do the colonies claim that they regard their negroes and people of colour as belonging to the category of men or to that of beasts of burden?' he asked. He went on to point out that the 'free people of colour are proprietors and tax-payers', implying that they were entitled to full citizenship rights, 'yet they have not been allowed to vote'. Mirabeau insisted that if 'the colonists mean to consider the Negroes and the people of colour as men, let them free the former; let them give them the right to vote and to be elected'. Carrying the colonists' reasoning to the absurd, Mirabeau concluded by reminding them that 'in setting the number of deputies in proportion to the population of France, we have not taken into consideration the number of our horses or our mules.' ${ }^{26}$

In an address to the National Assembly on October 22, 1789, drawn up by a meeting of people of colour living in Paris, the charge of inconsistency was reiterated. They advanced the assumption of the legal unity of the French empire and referred directly to the Declaration of the Rights of Man and Citizen that had been proclaimed only a few months earlier on August 26, $1789 .{ }^{27}$ The 'unfortunate American colonists known in the islands under the name of mulattoes, quadroons, etc.', the address stated, claim their 'inalienable rights [...], those rights that you have solemnly recognized and so faithfully established when you established as the foundation of the constitution "that all men are born and remain free and equal in rights"'. 28

$26 \quad A P 8$, p. 186.

27 On the free people of colour in Saint-Domingue and France, see D. Garrigus, Before Haiti: Race and Citizenship in French Saint-Domingue (Basingstoke: Palgrave Macmillan, 2006); Gauthier, L'Aristocratie de l'épiderme, but see Jeremy Popkin's critical review of Gauthier's book on H-France Review 9 (2009), No. 3 .

28 'Discours de M. Joly au nom d'une députation des hommes de couleur', 22 Octobre 1789, $A P$ 9, p. 482. Translation taken from Dubois and Garrigus, Slave Revolution in the Caribbean, pp. 68-69. 
Their address was part of a broader campaign for civic and political equality for gens de colour led by wealthy coloured planters Julien Raimond and Vincent Ogé, who presented themselves in Paris as 'colons américains'. Between 1789 and 1793 Raimond would write a number of notable pamphlets and become a respected as well as despised voice on colonial matters. ${ }^{29}$ Through his efforts, the cause of Saint-Dominguan free people of colour was quickly embraced by the Société des Amis des Noirs. This Paris-based antislavery society, founded in February 1788 by Jacques-Pierre Brissot, included prominent revolutionaries such as Condorcet, Lafayette, Mirabeau and the Abbé Grégoire. ${ }^{30}$ Initially members of the Société des Amis des Noirs were hardly concerned with free people of colour. ${ }^{31}$ The society's declared purpose was to bring an end to the slave trade and in its wake the gradual abolition of the institution of slavery. ${ }^{32}$ Until early 1789, the Abbé Grégoire was hardly even interested in colonial affairs and ridiculed those who reserved their charity and generosity for people 'two thousand leagues distant. ${ }^{33}$ Raimond, on the other hand, a plantation slaveholder himself, was primarily concerned with the civil emancipation of the free coloured population and only in a later stage occasionally advocated the gradual emancipation of black slaves.

During the first two years of the revolution, the French proslavery lobby, a powerful, well-connected, and wealthy group of men, was highly successful in thwarting the attempts of the Société des Amis des Noirs to place the ending of

29 Julien Raimond's most important publications include Observations adressées à l'Assemblée Nationale par un député des colons américains (n.p., 1789); idem, Observations sur l'origine et les progrès du préjugé des colons blancs contre les hommes de couleur (Paris: Belin, 1791); idem, Réflexions sur les véritables causes des troubles et des désastres de nos colonies (Paris, 1793). On Raimond, J.D. Garrigus, 'Opportunist or Patriot? Julien Raimond (1744-1801) and the Haitian Revolution', Slavery \& Abolition 28 (2007), pp. 1-21.

30 J.D. Popkin, You Are All Free: The Haitian Revolution and the Abolition of Slavery (Cambridge: Cambridge University Press, 2010), pp. 34-36. For the Société des Amis des Noirs, see M. Dorigny and B. Gainot, La Société des amis des Noirs, 1788-1799: Contribution à l'histoire de l'abolition de l'esclavage (Paris: Editions UnesCo, 2006), and D.P. Resnick, 'The Société des Amis des Noirs and the Abolition of Slavery', French Historical Studies 7 (1972), pp. 558-569.

31 The founding statement of the society did not mention free people of colour: J.-P. Brissot, Discours sur la nécessité d'établir à Paris une société pour concourir, avec celles d'Amérique \& de Londres, à l'abolition de la traite \& de l'esclavage des nègres (Paris: n.p., 1788).

32 Condorcet, 'Règlement de la Société des amis des noirs' (1788), included in Condorcet, Political Writings ed. S. Lukes and N. Urbinati (Cambridge: Cambridge University Press, 2013), pp. 148-155.

33 H. Grégoire, Essai sur la régénération physique, morale et politique des Juifs (Paris: Éditions du Boucher, 2002 [1789]), p. 109. Cf. M. Dorigny, 'Grégoire et le combat contre l'esclavage pendant la Révolution', in: M. Dorigny and Y. Bénot (eds.) Grégoire et la cause des noirs (1789-1831). Combats et projets (Paris: Société française d'histoire d'Outre-mer, 2005), pp. $51-68$. 
the slave trade on the political agenda at all. As a consequence, members of the Société reckoned it a more efficient strategy to redirect their priorities and embrace with considerable enthusiasm the cause of free people of colour, at least for the moment. Their claim for equal French citizenship had come to be seen as a noble aspiration in itself. ${ }^{34}$

\section{Slavery and Civic Inequality in the US before Saint-Domingue}

The early efforts of the Saint-Dominguan gens de couleur demanding civic equality aroused various and opposite feelings in different parts of the United States. Structural differences ought to be kept in mind when considering reactions in France, the Dutch Republic, and the United States to the different phases of the Haitian Revolution. Whereas France and the Dutch Republic during the 1790 secame remodelled as overseas republican colonial empires, the newly independent United States had no distant colonies. But they were an expanding continental empire, that is, into the North American continent. ${ }^{35}$ During this period, the North American continent was not a 'blank slate' but a battleground for 'interimperial competition'.36 As John Craig Hammond has suggested, the growth and expansion of an 'empire of slavery' in late eighteenth and early nineteenth-century Ohio, Missouri and the Mississippi Valleys, where the gradual extension of American sovereignty went hand in hand with the protection of the slave system, was not a sharp break with the past but

34 J. Popkin, 'The French Revolution's Other Island', in: Geggus and Fiering (eds.) The World of the Haitian Revolution, pp. 199-222, at pp. 203-204.

35 E.H. Gould, Among the Powers of the Earth: The American Revolution and the Making of a New World Empire (Cambridge, MA: Harvard University Press, 2012); E.H. Gould and P.S. Onuf (eds.) Empire and Nation: The American Revolution in the Atlantic World (Baltimore, MD: Johns Hopkins University Press, 2005); E. Hinderaker, Elusive Empires: Constructing Colonialism in the Ohio Valley, 1673-1800 (Cambridge: Cambridge University Press, 1997); P.J. Kastor and F. Weil (eds.), Empires of the Imagination: Transatlantic Histories of the Louisiana Purchase (Charlottesville, VA: University of Virginia Press, 2009); P.S. Onuf, Jefferson's Empire: The Language of American Nationhood (Charlottesville, VA: University Press of Virginia, 2000); A. Rothman, Slave Country: American Expansion and the Origins of the Deep South (Cambridge, MA: Harvard University Press, 2005); A. Taylor, The Divided Ground: Indians, Settlers, and the Northern Borderland of the American Revolution (New York: Alfred A. Knopf, 2006); R. White, The Middle Ground: Indians, Empires and Republics in the Great Lakes Region, 1650-1815 (Cambridge: Cambridge University Press, 1991).

36 J. Burbank and F. Cooper, Empires in World History: Power and the Politics of Difference (Princeton, N.J.: Princeton University Press, 2010), pp. 252, 260; J.C. Hammond, 'Slavery, Settlement, and Empire: The Expansion and Growth of Slavery in the Interior of the North American Continent, 1770-1820', Journal of the Early Republic 32 (2012), pp. 175-206. 
rather a continuation of the practices of the Caribbean and North American British, French and Spanish empires. These regions in the North American interior were closely related to the greater Caribbean plantation world through commercial connections, trade networks (including slave networks), personnel, migration, and culture. Indeed, as Hammond puts it: 'In the history of empires and slavery in the North American interior, the ultimate exclusion of slavery from the old Northwest was exceptional', not the slave based American imperial expansion in the South and Mid-West. ${ }^{37}$

While in the Dutch and French empires slavery existed only in their distant colonies, in the social fabric and political culture of the American republic black slavery was a central domestic element, although varying from state to state. In 1790 the United States counted around 700,00o black slaves and 60,000 free blacks on a total population of 3.9 million people..$^{38}$ Ninety percent of the enslaved black population lived in the southern states. ${ }^{39} \mathrm{New}$ states that joined the Union in the 179os, such as Kentucky (1792) and Tennessee (1796), became slave states with slave laws modelled on those of North Carolina and Virginia. In the North, in contrast, Vermont had abolished slavery in 1777. Gradual abolition laws were adopted in Pennsylvania (1780), Connecticut and Rhode Island (both 1784), and New York (1799). New Jersey followed in 1804. Massachusetts never formally abolished slavery until 1865 , but judicial decisions were made against slavery during the $1790 \mathrm{~s}$. By 1800 , slavery was almost extinct in the northern states. Whereas in France and the Dutch Republic slavery and the presence in society of black and coloured peoples as such, was a distant, colonial affair, Americans struggled with the question how to forge a multiracial republic. The issue of slavery and abolition was a much more contentious and politicized domestic issue in the early American republic than in either France or the Dutch Republic.

Abolitionist and manumission societies had been founded in Philadelphia (Pennsylvania Abolition Society) and New York (New York Manumission Society) as early as 1775 . Other societies were formed in Delaware, Rhode Island, Maryland, Connecticut, and Virginia. ${ }^{40}$ Some of them were joined by influential

37 Hammond, 'Slavery, Settlement, and Empire', p. 203.

38 Between 1790 and 1820 the free black population increased from nearly 6o,0oo to over 230,000 in 1820 . At the same time, the total number of slaves rose by nearly three quarters.

39 M.I. Lowance, Jr. (ed.) A House Divided. The Antebellum Slavery Debates in America, $1776-$ 1865 (Princeton, N.J.: Princeton University Press, 2003), pp. 5-6. Philadelphia in particular was known for its large free black population (around 1,800 in 1790).

40 The full name of the Pennsylvania Abolition Society, founded by a group of Philadelphia Quakers, was 'Pennsylvania Society for Promoting the Abolition of Slavery and the Relief 
founding fathers. Several east coast cities had considerable free black communities who founded their own abolitionist societies. Most prominent among them was the Free African Society founded in 1786 in Philadelphia, the city with the greatest free black population (around 6.00o). The societies were heavily criticized by spokesmen of white southern planters. Slavery increasingly became a sectional issue, with slaveholding southern states where abolitionism was marginal and almost slave-free northern states.

Although during the 1780 s and 1790 s slavery merely vanished in the northern states, none granted free blacks full citizenship. Freedom from slavery, as free black Americans became all too aware, was not the same thing as equal citizenship. In the immediate aftermath of the ratification of the constitution in 1789 , free black people were allowed to vote in a number of northern states. But between 1790 and 1835 the voting rights of free black people - as well as numerous other fundamental rights - actually became more restricted in virtually all states. The citizenship that free black Americans did enjoy for a while, and only in some states, was second-class citizenship at best. For blacks in the north, freedom came by degrees, civic inequality in rights and liberties was a permanent fact of life. ${ }^{41}$

On a Federal level, the Constitution of 1789 had fully acknowledged the existence of slavery by adopting the so-called 'three-fifth compromise' which stipulated that black slaves who under state laws were officially the owner's property and not allowed to vote, were counted for three-fifth in determining a state's total population, which in turn determined the apportioning of representatives, presidential electors, and direct taxes. ${ }^{42}$ The Naturalization Act of

of Free Negroes Unlawfully held in Bondage'. The Society was joined by influential revolutionaries such as Benjamin Rush. Benjamin Franklin was chosen as President in 1787. The New York Manumission Society counted prominent statesmen such as John Jay and Alexander Hamilton among its members. See J.R. Oldfield, Transatlantic Abolitionism in the Age of Revolution. An International History of Anti-Slavery, c. 1787-1820 (Cambridge: Cambridge University Press, 2013), pp. 15-23.

41 Free blacks could vote for a while in North Carolina, New York, New Jersey, Pennsylvania, Massachusetts, Rhode Island, New Hampshire, Delaware, Maryland, and Vermont. Bradburn. Bradburn, The Citizenship Revolution, pp. 262-271; R. Horsman, The New Republic. The United States of America, 1789-1815 (London: Longman, 2000), pp. 149-150. On abolition and emancipation in the northern states in the late eighteenth century, see G.B. Nash and J.R. Soderlund, Freedom by Degrees: Emancipation in Pennsylvania and its Aftermath (New York: Oxford University Press, 1991); J.W. Sweet, Bodies Politic: Negotiating Race in the American North, 1730-1830 (Baltimore, MD: Johns Hopkins University Press, 2003); S. White, Somewhat more Independent: The End of Slavery in New York City, 1770-1810 (Athens, GA: University of Georgia Press, 1991).

42 The relationship between the American constitution and slavery is still a topic of heated debates. See S. Wilentz, 'Constitutionally, Slavery Is No National Institution', New York 
1790, as well as the Militia Act of 1792 (providing for the organization of state militias) explicitly excluded black people, although the federal government did extend citizenship certificates to sailors of all races. ${ }^{43}$ In February 1793, moreover, Congress adopted the controversial Fugitive Slave Law which allowed local authorities to arrest and return runaway slaves, a measure decried by northern abolitionists and free blacks. In sum, over the course of the 179os, the Federal government furthered the interests of the slaveholding South, did little to fight slavery, and on the whole rejected the idea of equal citizenship for enslaved and free blacks alike.

If the struggle for emancipation by enslaved and free black people, as well as white abolitionists, neither stopped the expansion of slavery in the South nor led to full civic equality in non-slaveholding states, it nonetheless did put the very idea of slavery and civic inequality on the defensive. ${ }^{44}$ Thomas Jefferson's infamous suggestion in his Notes on the State of Virginia (1785) that black people belonged to another race which had certain innate inferior physical, mental, and moral characteristics, was not widely shared. More prevalent was the view, especially among those who considered themselves 'enlightened' Americans, that the experience of slavery as such had degraded the enslaved to an inferior status. Antislavery advocates, from the French-born Philadelphian Quaker Anthony Benezet to the revolutionary and physician Benjamin Rush, to the College of New Jersey professor Samuel Stanhope Smith rejected slavery. But they also rejected the immediate emancipation of black slaves into citizens. They all believed that enslaved and freed blacks were inferior to whites. In Nicholas Guyatt's summary: 'Temporarily and reversibly inferior, perhaps, and degraded through no fault of their own, but inferior nonetheless.' 45

During the 1780 s and 1790 s, (white) initiatives and plans for 'gradual' emancipation, educational programs, and children's schooling, often remained on

Times, September 16, 2015; L. Goldstone, 'Constitutionally, Slavery Is Indeed a National Institution', New Republic, September 17, 2015; D. Waldstreicher, 'How the Constitution Was Indeed Pro-Slavery', The Atlantic, September 19, 2015. More generally, see D. Waldstreicher, Slavery's Constitution. From Revolution to Ratification (New York: Hill and Wang, 2009).

43 N. Perl-Rosenthal, Citizen Sailors. Becoming American in the Age of Revolution (Cambridge, MA: Harvard University Press, 2015).

44 Cf. M. Mason, 'Necessary but Not sufficient. Revolutionary Ideology and Antislavery Action in the Early Republic', in: J.C. Hammond and M. Mason (eds.) The Politics of Bondage and Freedom in the New American Nation (Charlottesville, VA: University of Virginia Press, 2011), 11-31.

45 N. Guyatt, Bind Us Apart: How Enlightened Americans Invented Racial Segregation (Oxford: Oxford University Press, 2016), p. 38. 
the drawing board. ${ }^{46}$ Most important to their own emancipation were blacks themselves. Plans for wide-scale deportation of the black population to black colonies were envisioned by those who simply could not imagine, and would never accept living on an equal footing with a majority of free black people. But these plans never materialized during this period. ${ }^{47}$ When news from Saint-Domingue reached the shores of the United States, public opinion on slavery and the civic status of the free black population was a sectionally divisive and a politically sensitive issue. But on the level of the Federal government there was a consensus that the south could continue and expand their 'peculiar institution'.

Although Americans through their own revolution had become familiar with the logic of rights talk, the French revolution and Saint-Domingue re-ignited this discourse but in an even more universalistic key. The New-York Daily Gazette, for example, reported as early as December 1789 that a deputation of free coloured citizens was 'admitted at the bar' as 'the cry of liberty had extended to their hemisphere. The tone of southern papers such as Charleston's City Gazette (South Carolina) was entirely different: it warned that ' $\mathrm{t}$ ] he rage for tumult and insurrection diffused through all the French West-India Islands, has infected the free mulattoes of St. Domingo'. According to the SouthCarolinian journalist, the effects of raising coloured people to the status of whites would be disastrous and terminate in 'the total dissolution of the civil bonds which must necessarily correct and unite all ranks once compacted in the state of society!' Yet for all the difference in tone and evaluation, both commentaries mentioned that the free coloureds were "[i]nstructed by the declaration of the rights of man and citizens' (New-YorkDaily Gazette) and 'attempting to discuss the rights of mankind and all constitutional questions' (Charleston City Gazette). From the very beginning, then, from New York City to Charleston, efforts of Saint-Domingue free coloured people to obtain equal citizenship were interpreted through the lens of the applicability of rights declarations within the realm of the colonial empire. ${ }^{48}$

In revolutionary France, while the spokesmen of the gens de couleur and the Société des Amis des Noirs invoked the logic and authority of the Declaration of the Rights of Man and Citizen, the defenders in France of a colonial hierarchy based on skin colour denied free people of colour full civil and political rights.

46 M. Sinha, The Slave's Cause. A History of Abolition (New Haven, Co: Yale University Press, 2017), p. 90.

47 Guyatt, Bind Us Apart.

48 New-York Daily Gazette (New York, New York), December 25, 1789; The City Gazette, Or The Daily Advertiser (Charleston, South Carolina), November 22, 1790. 
They did not argue that the latter lacked the capacities to justifiably claim and exercise the rights of citizenship, but rather used the more indirect reasoning that the Declaration's principles were overall inapplicable to a colonial society that differed so much from the mother country. This view was expressed most clearly by Antoine Barnave, chair of a special Colonial Committee set up by the National Assembly in March 1790:49

Whether we consider them in their interior, or examine the relationships which tie them to the metropolis, we feel that the rigorous and universal application of general principles cannot be suitable [for the colonies]. In the specific case we have to examine, the difference in places, mores, climate, and products seemed to us to require a difference in laws, relations of interest, and position between France and her colonies, [they] do not have the same nature as those that tie the French provinces to either the national body, or with each other, the political relations between them have to differ as well; and we do not believe that the colonies could be included in the constitution that is ordained for the kingdom. ${ }^{50}$

Earlier, Gouy d'Arcy, an influential Saint-Domingue deputy, had equally emphasized the special status of colonies, stressing that 'Saint-Domingue should not be compared to the provinces of the kingdom. The colony is distant; it is isolated; the soil, the inhabitants, modes of cultivation, sources of wealth, everything there is different'.51 Likewise, deputy Jean-Baptiste Nairac from the port city of Bordeaux insisted in that same debate that 'the colonies should not be considered a part of the patrie' but as 'dependencies of it'.52 Since the balance of power in the National Assembly was still heavily on the side of the plantation class during this early phase of the revolution, the Colonial Committee's view won the National Assembly's vote. The decree passed on March 8,1790 , explicitly excluded the colonies from the constitution and left the authority to decide over internal political affairs, including the issue of citizenship, within the hands of white planters. ${ }^{53}$

49 On the committee, see V. Quinney, 'The Problem of Civil Rights for Free Men of Color in the Early French Revolution', French Historical Studies 7 (1972), pp. 544-557.

50 $\quad A P 12$ (8 March 1790), p. 71.

$5^{1} \quad A P 8$ (3 July 1789), p. 188. Also quoted in Popkin, 'The French Revolution's Other Island', at p. 202.

$5^{2} \quad A P 8$ (4 July 1789), p. 189. Also cited in Popkin, 'The French Revolution's Other Island', p. 202.

53 Dubois, Avengers of the New World, pp. 84-85. 
The decree of March 1790, however, left unspecified who would be granted the status of citizens. In October and November 1790, both Grégoire and Brissot published pamphlets attacking the decree as contradicting the 'eternal rights of man'. According to Grégoire, the free people of colour must be considered 'an integral part of the French empire, and accordingly must be citizens'. ${ }^{4}$ Around the same time, one of the leaders of the free coloured people, Vincent Ogé, secretly returned to the colony where he arrived in October1790. Ogé assembled an army and demanded that free coloured people were given full citizenship rights without distinction. Ogé's army, however, was soon crushed. On February 6, 1791, Ogé was tortured to death, his follower who were not able to flee publicly executed. When news reached France of the white planters' ruthless execution of the coloured rebel Vincent Ogé, public opinion and the general political tide began to turn against the increasingly radicalized planters. After a heated debate in May 1791, a majority within the National Assembly decided to grant full citizenship to a limited number of free men of colour born of free property-owning parents.

A significant outcome of these early debates was that members of the Société des Amis des Noirs and their allies became adamant in insisting that the French colonies be considered as an integral part of one, indivisible French republic. The cause of the free people of colour had become another element in the revolutionary regeneration of France and its colonial empire. ${ }^{55}$ When on 15 May, 1791, citizenship was granted to all people of colour born of free parents, the Abbé Grégoire exclaimed in his June 1791 Lettre aux citoyens de couleur et nègres libres de Saint-Domingue et des autres isles françoises de l'Amérique (Letter to the Citizens of Colour and Free Negroes of Saint-Domingue and the other French Islands of America): 'Friends! You were men; - you are now citizens'. Grégoire had shaken off his former nationally confined outlook and instead told his coloured friends that '[t]he resurrection of the French empire opened your hearts to hope. He furthermore removed all remaining doubts about the dependency and direction of influence between France and her colonies. 'It is we', Grégoire made clear, 'who, at the distance of two thousand leagues from you, have been constrained to protect these children'.56 Continuing his self-congratulatory tone he mentioned that 'we please ourselves in the

54 Henri Grégoire, Lettre aux philantropes sur les malheurs, les droits et les réclamations des gens de couleur de Saint Domingue et des autres îles françoises de l'Amérique (Paris, October 1790), pp. 1, 9 .

55 Dubois, Avengers of the New World, p. 196.

$56 \quad$ H. Grégoire, Lettre aux citoyens de couleur et nègres libres de Saint-Domingue et des autres isles françoises de l'Amérique (Paris: Imprimerie du Patriote Français, 1791), pp. 1-2 (emphasis in original). 
belief, that our decree will draw the bands still closer which unite you to the metropole'. French citizenship, however, required absolute loyalty: 'If you act unfaithfully to France, you will be the basest and most abandoned of the human race'. Hence, future generations had to be instructed carefully: 'Devotedly obedient to the laws, teach your children to hold them in high esteem [...] so shall you prepare for the succeeding generation virtuous citizens, public men, and defenders of their country!' Citizenship was to be seen as a gift from 'la mère-patrie', as Grégoire urged them to take your children to 'your shores', 'point their gaze to France' and tell them that 'from thence we have received liberty, justice, and happiness.'57

The decree granting citizenship to free people of colour, although it left slavery untouched, presented a vision of equality and citizenship. The French 'imperial' revolution of 1789 and mid-1791 expanded the agenda of the equality of the rights of man. In the following years it would encourage abolitionist Americans and anti-slavery activists who thought their own revolution was still unfinished to imagine themselves being part of a larger, universalistic emancipation project.

It also did not take long for a reaction to come forth against such emancipation rhetoric. In mid-July 1791 American newspaper readers in New York, Massachusetts, Rhode Island, Connecticut, and elsewhere could read about Edmund Burke's scathing charges filed in late April and early May 1791 against the French National Assembly. The occasion was the debate in the British House of Commons over the Quebec Bill concerning the constitutional government of Canada (which had come under British rule after the Seven Year's War). Saint-Domingue figured prominently in Burke's speech. The debate, a significant moment in the split at the heart of the Whig opposition between Burke and Charles James Fox, was widely reported in the American press. ${ }^{58} \mathrm{On}$ several occasions, Fox had publicly expressed his admiration for the French Revolution. He even suggested that the former French colony of Canada might best be offered a version of the French constitution. In his reply, Burke brought up 'as an instance of the effects of the Rights of Man [...] the sad condition of the French West-India Islands, since the importation of the Parisian frenzy into that quarter of the world'. Burke described the spread of revolutionary

57 Grégoire, Lettre aux citoyens de couleur, pp. 11, 14.

58 The report of the debate appeared in newspapers in New York, Massachusetts, Rhode Island, and Connecticut. The Daily Advertiser (New York, New York), July 16, 1791; Columbian Centinel (Boston, Massachusetts), July 16, 1791; The Providence Gazette and Country Journal (Providence, Rhode Island), July 23, 1791; Connecticut Courant (Hartford, Connecticut), July 25, 1791. For background, see R. Bourke, Empire and Revolution. The Political Life of Edmund Burke (Princeton, N.J.: Princeton University Press, 2015), pp. 763-767. 
principles in the colonies in terms of the infectious zeal of the French: 'The fatal venom of democracy infected every breast; the Free Men and Slaves, the Blacks, the Whites, the Party Coloured inhabitants partook alike of the dire phrensy'. The island was 'thrown into confusion and ruinous disorder' by 'the new principles which had fermented in the giddy brains of the mother country'. Whereas Burke expressed his admiration of the republican government in the newly independent United States, he dismissed the French 'pretended Republican government' as a 'mad democracy' the principles of which 'entered into the colonies opening up 'Pandora's box'.59 Such language, relating 'French' conceptions of democracy to the free coloured people and black slaves who were 'infected' by it, and the 'sad condition' of Saint-Domingue would become a mainstay in the argumentative arsenal of American conservative and proslavery critics of France's imperial revolution. For these critics, the massive slave insurrection that erupted in August 1791 and the events that followed confirmed Burke's warning for the opening up of Pandora's box. For those Frenchmen, Americans, and Dutchmen who supported the expansion of citizenship to free coloured people, the question of revolting black slaves generated a whole new set of considerations.

59 The Daily Advertiser (New York, New York), July 16, 1791 (italic in original). 


\section{The Civilizational Limits of Citizenship}

The 1792 issue of the Historiesch schouwtooneel van 's waerelds lotgevallen (Historical Theatre of the World's Vicissitudes), a respected Dutch spectatorial magazine on international affairs, enthusiastically welcomed the French Legislative's Assembly's decision of 15 May 1791 to extend full citizenship to free men of colour born of free parents. ${ }^{1}$ Once the decree had reached SaintDomingue, the Historiesch schouwtooneel reported, 'all classes of free inhabitants' gathered to celebrate the 'federation-feast' of July 14. 'Whites, Mulattoes, free negroes, National Guards, troops of the line', all joined together to rescue the northern district from the 'insurgent negroes' whom the magazine depicted as 'rebels'. While the magazine cheered 'the much-needed reconciliation of whites and people of colour', the extension of citizenship to black rebels seemed out of the question. ${ }^{2}$

The image of Saint-Dominguan whites and free people of colour brotherly celebrating July 14th, however, was soon substituted for 'scenes of destruction, murder, arsons, in one word, civil war', as the Batavian Revolution's most influential writer and founding father Pieter Paulus put it in his famous 1793 Treatise on Equality. ${ }^{3}$ The leading Orangist publicist Adriaan Kluit, an outspoken ideological opponent of Paulus and a fierce critic of his compatriot admirers of French revolutionary ideas, similarly wrote of the islands' 'catastrophic and miserable state. ${ }^{4}$ Kluit imputed the catastrophe of Saint-Domingue to French 'foolishness'. They had 'introduced there [Saint-Domingue] mistaken doctrines of liberty $[\ldots]$ and principles under the guise of lovely appearances', he fulminated, 'and endeavoured to let impracticable maxims of a reckless Patriotism

1 For 'respected' see the review in Vaderlandsche Letteroefeningen (1793), vol. 1, p. 488. http:// www.dbnl.org/tekst/_vadoo3179301_01/_vadoo3179301_01_0141.php. Date of access: 11-7-2013.

2 Historiesch schouwtooneelvan 's waerelds lotgevallen; in het jaar 1792, 4 vols. (Haarlem: Loosjes, 1792), vol. 3, pp. 397-400.

3 Paulus, Verhandeling, p. 207.

4 [Adriaan Kluit], De rechten van den mensch in Vrankrijk, geen gewaande rechten in Nederland. Of Betoog, dat die rechten bij het volk van Nederland in volle kracht genoten worden en iets over onze vrijheid en patriotismus. Door een patriot [The Rights of Man in France, No Pretended Rights in The Netherlands, or Demonstration that those Tights are enjoyed to the Full Extent by the People of The Netherlands; and Something about our Liberty and Patriotism. By a Patriot] (Amsterdam: W. Brave, 1793), p. 50. 
apply'. ${ }^{5}$ Such dire images of Saint-Domingue would come to haunt the minds of Dutch politicians, thinkers and journalists for years to come.

Between 1790 and 1793, several Dutch newspapers reported on the island's 'revolt', the 'fermentations' and the 'skirmishes'. ${ }^{6}$ But Paulus and Kluit were the first two prominent Dutch opinion makers of the early 179os who devoted serious attention to the slave uprising. The insurrection broke out in August 1791 in Saint-Domingue's Northern Province, a few miles outside of the port city of Cap Français. Within a few months a growing group of black insurrectionists were able to take control of most parts of the Northern Plain. Hundreds of coffee and sugar plantations were attacked and set to flames, many white plantation owners and their families killed. Almost simultaneously an army of free coloured people rose in the island's west province where white landowners were eventually forced to accede to their demands of admission to local representative assemblies.

The news of the insurrection reached Paris in late October. It incited turbulent debates both inside and outside the Legislative Assembly about the question who was responsible for what was widely considered a deeply troubling situation. As important was the question how it could be suppressed. An extra complicating factor was that on 24 September, one month before the news of the insurrection would reach Paris, the National Assembly had reversed the 15 May decree granting people of colour (born of free parents) citizenship. It only enhanced the impression that the metropole's policy was oscillating and confused. After months of vehement disagreement and mutual recriminations, members of the Société des Amis des Noirs, Brissot most prominently, pushed the Legislative Assembly to grant all free people of colour equal citizenship rights. Only by uniting white and free coloured citizens, they argued, order could be restored. The law was signed by King Louis XVI on April 4, 1792. A (second) Civil Commission led by Étienne Polverel and Léger-Félicité Sonthonax, two Jacobins who had earlier opposed slavery in writing, was instructed to enforce the controversial law and put down the slave insurrection with the help of 6,ooo troops. The Civil Commission forged alliances with various groups of free people of colour, but were unable to restore order, as they faced recalcitrant whites allying with British forces and black insurgents allying with Spanish forces from Santo Domingo. Not surprisingly, the leadership of the

5 [Kluit], De rechten van den mensch in Vrankrijk, geen gewaande rechten in Nederland, p. 50.

6 Groninger courant, 9 March 1789, 15 October 1790, 27 August 1793; Oprechte Haerlemsche courant, 8 November 1791; Ommelander courant 30 November 1792, 30 July 1793; Rotterdamse courant, 27 July 1793 . 
black insurgents distrusted the French and were not willing to give up their position.

In June 1793, the situation on the island toppled when the Civil Commissioners summoned the help of black insurgents to fight as free soldiers of the French Republic against white troops in Cap Français. In the chaos of subsequent fighting, as white soldiers were fleeing to their ships, the wealthiest European colonial city of the Caribbean went up in flames. By late August 1793, Sonthonax and Polverel became convinced that only a general emancipation decree could win the black insurgent armies over to their side. First in the North, on August 29, and in the South and the West the following months, the Civil Commissioners decreed that all former slaves would enjoy 'all the rights of French citizens. ${ }^{7}$ In doing so, they revolutionized the social and racial hierarchy on the island for good.

Paulus's and Kluit's interpretations of the 1791 uprising point to two issues concerning the insurrection that throughout the 1790 s would be subject to conflicting interpretations and representations: what was the nature of this insurrection and the insurrectionists involved in it? And what had caused it? Paulus attributed the slave insurrection and civil war to the 'rash' French decision to suddenly liberate the 'entire' enslaved black population. Of course, as human beings, Paulus argued, 'the African people' have the same rights as Europeans. But giving them equal rights and liberties must be done 'gradually', as the 'fatal consequences' of revolutionary France's 'abrupt' liberation policy conclusively demonstrated. What is most intriguing about Paulus' publication and his claim about French imperial policies is that they actually preceded the emancipation decrees of the Civil Commissioners on Saint-Domingue of June 1793 and their ratification by the French National Convention in February 1794. His factually incorrect explanation tells us a lot about how the (admittedly very complex) relationship between a French radical ideology and the events in Saint-Domingue was perceived and represented at the time.

Historians have rightly pointed out that over the course of the nineteenth century 'competing narratives' of the slave insurrection emerged. But during the 1790 s and early nineteenth century the images drawn of the insurgency were predominantly dismal and horrific. ${ }^{8}$ The terms used by American, Dutch,

7 Dubois, Avengers of the New World, pp. 162-164.

8 Rugemer, The Problem of Emancipation, esp. Ch. 2. More generally, see Hunt, Haiti's Influence on Antebellum America; White, Encountering Revolution; Clavin, Toussaint Louverture and the American Civil War; J.D. Popkin, Facing Racial Revolution: Eyewitness Accounts of the Haitian 
and French commentators to describe the overall condition of Saint-Domingue in the years following the insurrection, such as 'anarchy' and 'wilderness', as well as the portrayal of black insurgents as uncontrollable, disorderly savages, with 'fiery' characters, taken over by 'relentless rage' and accustomed to 'African barbarism', functioned within a crude framework of 'civilized' and 'uncivilized' peoples. ${ }^{9}$ A crucially important and dominant line of response to the slave insurrection, although not the only one, consisted of the depiction of the revolting black slaves as uncivilized savages.

While the earlier stages of the Haitian Revolution in which white planters and free people of colour were involved had put the notion of national citizenship to the test, as their struggles had expanded the scope of national citizenship to the empire's colonies, the insurrection of black slaves raised yet other questions. Initially, these questions concerned responsibility for the insurrection and strategies for its containment, not whether black slaves too were to become citizens. Hardly anyone in revolutionary France - including the members of the Société des Amis des Noirs - was in favour of immediate emancipation. Those who supported equal citizenship rights for free people of colour instead underlined the constitutional unity of the French empire, the sovereignty of the nation's main representative body, and the soundness of the metropole's interventionist strategy. What they also reasserted was the civilizational hierarchy within the empire and the civic subordination of those who were deemed insufficiently enlightened. The Enlightenment language of the progress - and backwardness - of civilizations provided a mode to distinguish between legitimate claims for civic equality and what were considered violent and barbaric spasms of an illegitimate frenzy.

More conservative responses to this new phase of the Haitian Revolution emphasized the supposed lethal combination of, on the one hand, the primitive and savage nature of black slaves and, on the other hand, the extension of the principles of freedom and equality as enshrined in declarations of the rights of man. According to such interpretations, the savagery and destruction they associated with the insurrection proved that black slaves were insufficiently civilized to adopt the rights and duties of citizenship. To many Americans and Dutchmen, it proved that the French revolutionary ideology had spiralled out of control.

Insurrection (Chicago, IL: University of Chicago Press, 2007); Geggus (ed.), The Impact of the Haitian Revolution in the Atlantic World.

9 Cf. Hunt, Haiti's Influence on Antebellum America, pp. 20-22; White, Encountering Revolution, pp. 3,57 . 
The notion of a certain people's or social group's stage of civilization was more central to the demarcation of the limits of citizenship in 179os than is sometimes recognized. The rough distinction between civilized and uncivilized was part and parcel of what could be called a family of eighteenth-century theories of historical progress. Common to such 'philosophical histories' is that they conceive of history as the unfolding of a linear universal process. Within this unfolding process, several stages of development can be distinguished, each successive stage displaying a change in manners, laws, technology, customs, and morals. ${ }^{10}$

Although an Enlightenment thinker such as the mid-eighteenth-century French historian Antoine-Yves Goguet in his $175^{8}$ De l'Origine des Loix, des Arts, et des Sciences: et de leurs progrès chez les anciens peuples only differentiated roughly between two stages, other theorists, notably Anne-Robert-Jacques Turgot and Adam Smith, centring their approach on means of subsistence and societal relations, distinguished three or more stages in history: the earliest stage of hunter-gatherers, followed by a second pastoral stage; a third stage characterized by agriculture, and a fourth, final stage of commercial society, the most advanced stage. ${ }^{11}$ Other Enlightenment thinkers such as the Scottish historian William Robertson and the French philosophe and revolutionary Condorcet, while employing a similar language of stages distinguished by modes of subsistence, shifted the focus to what Jennifer Pitts has called the 'cognitive-development conception of progress.' ${ }^{12}$ Within this conception, history essentially displays, as Condorcet put it, 'the progress of the human mind'. According to such theories, people living in an early, primitive stage of society were, quite literally, mentally and morally 'infantile', comparable to children. 'In the early stages of society', William Robertson explained, 'while

10 Harvey, The French Enlightenment and its Others; Sebastiani, The Scottish Enlightenment; S. Stuurman, The Invention of Humanity. Equality and Cultural Difference in World History (Cambridge, MA: Harvard University Press, 2017); Whelan, Enlightenment Political Thought and Non-Western Societies.

11 For Goguet, see J.G.A. Pocock, Barbarism and Religion, 6 vols. (Cambridge: Cambridge University Press, 2001-2015), vol. 4: Barbarians, Savages and Empires, Ch. 3; N. Wolloch, "Facts, or Conjectures": Antoine-Yves Goguet's Historiography', Journal of the History of Ideas 68 (2007), pp. 429-449. On the four stages theory generally, see Meek, Social Science and the Ignoble Savage; Hont, 'The Language of Sociability and Commerce'. Technically speaking, Smith did not distinguish a fourth 'commercial' stage, since all stages evinced some level of commercial activity.

12 J. Pitts, 'Empire, Progress, and the "Savage Mind", in: J.T. Levy and I.M. Young (eds.) Colonialism and its Legacies (Lanham, MD: Lexington Books, 2011), pp. 21-52. 
the condition of man is simple and rude, his reason is but little exercised. ${ }^{13}$ Fundamental to such histories of the human mind is that the degree of enlightenment of the mind of a single human being paralleled the state of civilizational progress. Goguet's history of civilization was essentially governed by the same principle: "The history of laws, arts, and sciences, is, properly speaking, the history of the human mind. ${ }^{14}$ Whereas there was a well-established although not uncontradictory - French tradition of writing about 'noble savagery', stretching from Montaigne to Lahontan and Rousseau, Goguet's picture of the savage man, purportedly drawn on traveller's accounts, was anything but noble. Their character was 'cruel and ferocious' and they live in perpetual war [...] void of all the principles of humanity, without laws, polity, or government'. ${ }^{15}$ Although not always as vicious as Goguet's depiction, the distinction between civilized and uncivilized people had become a fairly uncontested element in the worldview of most Dutchmen and Frenchmen by the end of the eighteenth century. It is, indeed, remarkable how profoundly this understanding of inequalities in civilizational progress had taken root among broad sections of the public within only a few decades.

In the United States too, theories of progress and 'environmentalism', that is, the view that differences between civilizations, peoples, and races could be explained by environmental factors and stages of progress, were widely accepted, at least until the 179os. An hugely influential and particularly representative example of this kind of thinking is An Essay on the Causes of the Variety of Complexion and Figure in the human Species (1787) by the professor of moral philosophy at New Jersey College (renamed into Princeton University in 1896), Samuel Stanhope Smith. ${ }^{16}$ Departing from the proposition that 'mankind is a single species', Smith explained that 'by the state of society many varieties in the human person are formed'. The state of society, comprising 'diet, clothing, lodging, habits, face of the country, objects of science, religion,

13 W. Robertson, History of America, 2 vols. (Dublin: Whitestone, 1777), vol. 1, p. 308. Robertson's History of America was translated both into Dutch and French as early as 1778. A new and augmented French translation was published in Amsterdam in 1779 and again in 1789 . On Robertson and his reception, see S.J. Brown (ed.) William Robertson and the Expansion of Empire (Cambridge: Cambridge University Press, 2008).

14 As cited in: Pocock, Barbarians, Savages and Empires, p. 44.

15 Ibid, p. 46.

16 S. Stanhope Smith, An Essay on the Causes of the Variety of Complexion and Figure in the Human Species: To which are added Strictures on Lord Kaims's Discourse, on the Original Diversity of Mankind (Philadelphia, PA: R. Aitken, 1787). An enlarged and revised edition appeared in 1810. On Smith, see Dain, Hideous Monster of the Mind:American Race Theory in the Early Republic (Cambridge, MA: Harvard University Press, 2002), pp. 41-80; Guyatt, Bind Us Apart, pp. 61-63. 
interests, passions and ideas of all kind, infinite in number and variety', were the parameters that determine if a people live in a 'savage state' or in a 'state of civilization'. While Stanhope Smith deemed the 'progress of civilization' to be rather slow, he highlighted the 'immense [...] difference between the manners of Europe barbarous, and of Europe civilized. ${ }^{17}$ On this basis, he had no doubt that the 'emancipation of the African race in the United States [...] must necessarily be the slow and gradual work of time'.18

Arguably, drawing such distinctions between civilized and uncivilized peoples within a universal linear historical framework, as well as self-consciously identifying oneself as 'enlightened', were central aspects of an eighteenthcentury process of Western European and North-American intellectual and cultural identity formation. 'More than anything', Dan Edelstein acutely observed, 'the Enlightenment seems to have been the period when people thought they were living in an age of Enlightenment. ${ }^{\prime 9}$ But Enlightenment views on 'philosophical history' were not merely innocent modes of European reflexive self-understanding and self-description. They helped to establish a 'modern' discourse of inequality: the unavoidability of historical progress and historical backwardness - as expounded in such theories, brought about what Siep Stuurman calls a 'powerful inequality effect'. ${ }^{20}$

Philosophical theories of civilizational and cognitive progress (and backwardness) gained a pertinent political relevance in responses to the 'disaster' of Saint-Domingue. This discourse 'politicized' as the Haitian Revolution expanded the revolutionary agenda. ${ }^{21}$ Put differently, eighteenth-century schemas of civilizational inequality based on Enlightenment theories of historical progress culminated in responses to the Haitian Revolution and in debates concerning the limits of modern republican citizenship for black SaintDominguan insurrectionists. The reception of the Haitian Revolution, thus,

17 Smith, An Essay, pp. 44, 62-63, 86-87.

18 S. Stanhope Smith, 'On the Relation between Master and Servant', in: idem, Lecture... on Subjects of Moral and Political Philosophy, 2 vols. (Trenton, N.J.: Daniel Fenton, 1812), vol. 2, pp. 159-179, at p. 173 .

19 D. Edelstein, The Enlightenment: A Genealogy (Chicago, IL: University of Chicago Press, 2010), p. 73 .

20 Stuurman, The Invention of Humanity, p. 16. See also, J. Pitts, A Turn to Empire: The Rise of Imperial Liberalism in Britain and France (Princeton, N.J.: Princeton University Press, 2005).

21 Cf. T. Kaiser and D. van Kley, 'Introduction' and 'Conclusion' in: Kaiser and Van Kley (eds.), From Deficit to Deluge. For the political connotation that the word civilization took on, see P. Michel, 'Barbarie, Civilisation, Vandalisme', in: Reichardt and Schmitt (eds.) Handbuch Politisch-Sozialer Grundbegriffe, pp. 7-50. For a Dutch perspective, see Sens, 'Mensaap, heiden, slaaf'. 
provides a focal point where the language of the rights of man and the language of philosophical theories of historical progress clashed, were reconciled, and reconfigured. If the Haitian Revolution was a key-moment in the history of the universalization of rights, it was also a key-moment in the erection of argumentative walls against the universalization of rights.

The justifications for denying black slaves equal citizenship during the $1790 \mathrm{~s}$ put forth by contemporary observers in the Atlantic world drew much heavier upon Enlightenment theories of civilizational progress - and backwardness than has been recognized in the existing historiography. Laurent Dubois has qualified the ways in which colonial authorities excluded black slaves and ex-slaves from citizenship as 'republican racism..$^{22}$ But this way of describing the arguments endorsing exclusion does not capture the intellectual assumptions behind them: arguments for exclusion were not specifically or exclusively 'republican' in nature. Under Napoleonic authoritarianism and under nineteenth-century constitutional monarchies arguments based on civilizational backwardness for civic exclusion - and arguments in favour of a mission civilisatrice - were employed on a wide scale. ${ }^{23}$

Moreover, the 1790s discourse of civic exclusion that was applied to free and enslaved black people was by and large not strictly racist, at least not in the way that 'racism' developed as a more or less coherent body of (biological and scientific) thought in the nineteenth century. Of course, the discourse of civilization and historical progress was not the only available language to explain human diversity in the second half of the eighteenth century. As an everexpanding body of scholarship has established, Enlightenment theories of racial classification positing new hierarchical orderings increasingly gained ground in the second half of the eighteenth century. ${ }^{24}$ These theories were generally not based on a deep, biological conception of racial difference. Polygenism (the view that humanity had different progenitors) was advocated by some, if rather speculatively. ${ }^{25}$ Most people in the second half of the

22 Dubois, Colony of Citizens, p. 3; cf. L. Dubois, 'Republican Antiracism and Racism: A Caribbean Genealogy', French Politics, Culture \& Society 18 (2000), pp. 5-17.

23 A.L. Conklin, A Mission to Civilize: The Republican Idea of Empire in France and West Africa, 1895-1930 (Stanford, CA: Stanford University Press, 1997).

24 F. Bethencourt, Racisms. From the Crusades to the Twentieth Century (Princeton, N.J.: Princeton University Press, 2013); J.E.H. Smith, Nature, Human Nature \& Human Difference. Race in Early Modern Philosophy (Princeton, N.J.: Princeton University Press, 2015); Stuurman, The Invention of Equality, pp. 301-316.

25 The most prominent eighteenth-century polygenists, although varying in degrees of sophistication, were Lord Kames (Henry Home), Cornelius de Pauw, David Hume, and Voltaire. It would be a mistake, however, to simply equate polygenism with a pro-slavery stance (or, conversely, monogenism with an antislavery stance). See Curran, The Anatomy 
eighteenth century were hesitant to accept the idea that races were essentially different from each other. One important reason is that it seemed to contradict God's single creation and humanity's shared descent from common ancestors as told in Scripture. ${ }^{26}$ The French naturalist Georges-Louis Leclerc, count of Buffon (1707-1788) and the German anatomist, anthropologist, and professor of medicine, Johann Friedrich Blumenbach (1752-1840), arguably the two most influential eighteenth-century theorists of racial difference, defended the unity of the human species against polygenism. Whereas histories of civilizational progress studied the history of man in society (civic history), Buffon and Blumenbach studied man as part of the natural world. They explained the variety of the human species by considering nature 'in the succession of time', thus writing a 'natural history' of humanity's physical and cultural diversity in which climate and the environment were the overarching explanatory factors. ${ }^{27}$

Recent scholarship has taught us that there was no clear-cut division or opposition between eighteenth-century philosophical histories of civilizational progress and natural histories of racial difference. ${ }^{28}$ Yet what is crucial to see in relation to how these discourses were invoked and politically mobilized in reactions to the Haitian Revolution, is the default setting both discourses assume. Briefly put, for naturalists such as Buffon and his followers 'whiteness' was the 'global standard'; for philosophical historians such as Condorcet, European enlightened civilization was the universal norm. ${ }^{29}$ As both discourses rejected essentialist biological racism, the difference between the ways in which both discourses conceived of the capability or potential of enslaved Africans of being elevated to the level of (white) enlightened Europeans seems to have been a matter of degree.

of Blackness, pp. 190-199. On the relationship between race, monogenism and Protestant theology, see C. Kidd, The Forging of Races: Race and Scripture in the Protestant Atlantic World, 160o-200o (Cambridge: Cambridge University Press, 2006).

26 Kidd, The Forging of Races.

27 Bethencourt, Racisms, pp. 247-270; Stuurman, The Invention of Humanity, pp. 301-316.

28 Cf. Bruce Dain's remark: 'Racial concepts did not move tidily from a shallow Enlightenment environmentalism to a deep biology; nor were the two positions mutually exclusive. Nurture and nature intertwined. No linear progression led from essentially ethnocentric, superficial Enlightenment egalitarianism to an unequivocal, candid - and politically expedient - nineteenth-century "hard" racism. New work in the history of science teaches us that a sharp distinction between nineteenth-century biology and eighteenth-century natural history is not tenable'. Dain, Hideous Monster of the Mind, vii. On the relationship between natural and philosophical (civil) history, see Sebastiani, The Scottish Enlightenment, pp. 64-71.

'Global standard' is Stuurman's phrase. Stuurman, The Invention of Humanity, p. 306. 
But even if the distinction between natural history and the (civic) history of civilizational progress was not always sharp, during the 1790 s the prevailing scheme of thought was still largely couched in terms of civilizational inequality, progress and backwardness. One important reason why it was so widely invoked in the 1790 s was that it could be used with a certain flexibility. It enabled philosophers, revolutionaries, politicians and publicists on the progressive side of the transatlantic ideological spectrum to subscribe to a future vision in which non-white peoples had the potential to become equal citizens. They could accept civic inequality based on civilizational backwardness since it would only be temporary: it could be overcome. The discourse of civilizational progress accordingly enabled progressive revolutionaries to reconcile their commitment to revolutionary principles of equality with the denial of citizenship to people who were deemed insufficiently civilized. Those with more moderate or conservative views on the expansion of citizenship, as well as reactionary defenders of slavery, sometimes resorted to more biological (essentialist) approaches to racial inferiority. Most prominently, the creole jurist, writer, and representative par excellence of the French 'colonial Enlightenment' Médéric-Louis-Élie Moreau de Saint-Méry, as well as Thomas Jefferson, combined judgments on what they considered the physical and moral depravity of blacks with theories of racial degeneration and anxieties of racial intermixture. ${ }^{30}$ But opponents of emancipation in the Atlantic world also eagerly employed the language of civilizational backwardness, both to postpone the abolition of slavery and to justify their unequal civil status within society.

To be sure, the point is not that the Haitian Revolution as such brought bring into existence or cause the view that black slaves were uncivilized or unenlightened, and hence considered unfit for citizenship. As we have seen, throughout the 1780 s, black citizenship in American non-slaveholding states

30 On Moreau de Saint-Méry, see D. Brion Davis, The Problem of Slavery in the Age of Revolutions (Ithaca, N.Y.: Cornell University Press, 1975), pp. 184-195; J.D. Garrigus, Before Haiti: Race and Citizenship in French Saint-Domingue (New York: Palgrave, 2006), pp. 156-159. On Moreau and the 'colonial Enlightenment', M.W. Ghachem, 'Montesquieu in the Caribbean: The Colonial Enlightenment between Code Noir and Code Civil', in: D. Gordon (ed.) Postmodernism and the Enlightenment: New Perspectives in Eighteenth-Century French Intellectual History (New York: Routledge, 2001), pp. 7-30. On Jefferson, see D.R. Egerton, 'Race and Slavery in the Era of Jefferson', in: F. Shuffleton (ed.) The Cambridge Companion to Thomas Jefferson (Cambridge: Cambridge University Press, 2009), pp. 73-82; W. Jordan, White over Black. American Attitudes toward the Negro, 1550-1812 (Chapel Hill, N.C. University of North Carolina Press, 1968), pp. 429-481; M. Zuckerman, 'The Power of Blackness: Thomas Jefferson and the Revolution in St. Domingue', in: idem, Almost chosen People. Oblique Biographies in the American Grain (Berkeley, CA: California University Press, 1993), pp. 175-219. 
was limited and subject to fierce debates with varying, confused and unstable outcomes. In the most elaborate French antislavery tractate La cause des esclaves nègres (The Cause of Black Slaves), published in 1788, the Lyon Protestant pastor Benjamin Frossard suggested that 'Negroes are still in the infancy of civilization'. Only by teaching them the 'required religious and moral obligations', Frossard held, they could be sufficiently prepared 'to bear the respectable title of citizen.' ${ }^{11}$ Such writings preceded the Haitian Revolution, but many of its assumptions would be reproduced throughout the 1790 .

In the Dutch Republic too, the importance of one's degree of enlightenment so as to qualify for full-fledged citizenship was already fully articulated in 1790 . The Dutch translation of Frossard's text would become one of the most-cited antislavery texts at the time. ${ }^{32}$ In one of the Dutch Republic's most widely read spectatorial magazines of the late 1780 s and early 179os, the Bijdragen tot het menschelijk geluk (Contributions to Human Happiness), the Dutch journalist, remonstrant professor of theology, and prominent future Batavian revolutionary Jan Konijnenburg similarly posited that 'negroes' still resided quite literally in an age of civilizational infancy. He argued that just as 'to our children, the more their knowledge and experience increases, the more freedom we allow them; likewise, the negro who is still in a state of infancy should not be withhold his freedom forever. ${ }^{33}$ Konijnenburg, thus, put forth an exemplary articulation of a gradual expansion of citizenship: 'the stage of freedom' to be allowed to the 'Negroes', 'had to be proportional to their degree of enlightenment and civilization'. 'The more they show themselves' to be educated and 'well-behaved', Konijnenburg argued, the larger 'should be their share in the freedom and rights of the Dutch citizen.' ${ }^{34}$

Likewise, the Dutch radical patriot minister, poet and future politician Bernardus Bosch claimed in 1791 that slavery should be abolished since enslaved black people are our 'fellow human beings'. But again, this should be done gradually. 'Because we are so much more enlightened and civilized than they

31 B. Frossard, La cause des esclaves nègres et des habitants de la Guinée, portée au tribunal de la justice, de la religion, de la politique; ou Histoire de la traite \& de l'esclavage des nègres, preuves de leur illégitimité, moyens de les abolir sans nuire ni aux colonies ni aux colons, 2 vols. (Lyon: Imprimerie d'Aimé de la Roche, 1789), vol. 1, pp. 22-23.

32 B. Frossard, De zaak der negerslaaven, en der inwooneren van Guinéa ...; of, Historie van den handel, en de slavernij der negers; bewijzen van derzelver onwettigheid; middelen om die te vernietigen, zonder de colonien, of de colonisten te benadeelen, 2 vols., trans. E. Wolff-Bekker (The Hague: Isaac van Cleef, 1790).

33 [J. Konijnenburg], 'Proeve eener verhandeling over den slaavenhandel en den aankleeve van dien', Bijdragen tot het menschelijk geluk 4, (1790), pp. 86-87.

34 [Konijnenburg], 'Proeve', p. 84 (italics in original). 
[black people] are, we should rather treat such unhappy creatures with pity, endeavour to enlighten them, and in all kinds of ways promote their happiness'. ${ }^{35}$ Several years later, during the Batavian Revolution, this kind of reasoning could be heard everywhere.

Arguments concerning the 'backwardness' or 'savage state' of certain peoples - and the notion of the potential of their 'regeneration' - were not only applied beyond borders or the colour-line to, for example, free and enslaved Africans, indigenous Javanese or native North American peoples. They were also applied domestically, that is, to Jews, to (white) peasants, the urban poor, and to those who were seen as uneducated. They too were to be 'regenerated'.

In revolutionary France after the fall of Robespierre, critics of the Jacobin citizenship regime of 1792-1794, for example, accused Jacobin terrorists and their supporters of being unenlightened, even 'savage' peoples (see Chapter 5); Batavian revolutionaries could be heard arguing that the 'rabble' needed 'leading reins' (see Chapter 7). ${ }^{36}$ My concern here is not to systematically compare how the discourse of civilizational inequality was applied - or transposed - to various groups. The point rather is that he Haitian Revolution prompted the invocation and politicization of this discourse and led to feelings of disenchantment with 'revolutionary' universalism that became intertwined with and were echoed in domestic regimes of exclusion applied to the 'uncivilized' within. ${ }^{37}$

The notion of inequality in terms of enlightenment or civilizational progress was part of a more general discourse that lay at the heart of French revolutionary political culture. Confronted with the wave of claims and petitions by a range of suppressed social (minority) groups that the inner logic of universalistic language had invited, revolutionaries faced a penetrating question. As Alyssa Goldstein Sepinwall put it: 'How could they create a unified nation out of a country seemingly bursting with diversity - in religion, language,

35 B. Bosch, 'De slaavenhandel', De leerzame praat-al, II, no. 46-48 (November 16, 23, 30, 1791), pp. 361-384. Idem, no. 48, November 30, 1791, p. 384. The next issue of De leerzame praat-al of December 7, 1791, dealt with 'The natural Rights of Man and Citizen'.

36 Baczko, Ending the Terror, pp. 185-223.

37 William Max Nelson has interestingly argued that in late eighteenth-century France 'the new anthropological perspective that emerged in part from the Enlightenment engagement with colonial people and places was refashioned through projects of revolutionary regeneration' and that 'the internal anthropology that took shape during the Revolution and focused on knowing and transforming the French peasantry was linked to the earlier history of external colonization and external ethnography'. See W.M. Nelson, 'Colonizing France. Revolutionary Regeneration and the first French Empire', in: Desan, Hunt, and Nelson (eds.) The French Revolution in Global Perspective, pp. 73-85, at p. 75 . 
wealth, gender, geography, and race?'38 The concept of régénération, formerly a term that only appeared in religious and medical vocabularies, acquired a distinct moral and political meaning at the end of the eighteenth century. Its newly invested meaning was perhaps expressed most clearly in CharlesFrédéric Reinhard's Le néologiste français, ou vocabulaire portative des mots le plus nouveaux, according to which 'régénération' signifies 'an ameliorated reproduction, a physical, moral or political perfection of an object.' ${ }^{39}$

The notion of regeneration, as Mona Ozouf and Antoine de Baecque have pointed out, was a key-concept in French revolutionary political culture. The declaration of the rights of man and citizen occupied a central place in the process of the revolutionary regeneration of man. It ushered in the era of what was sometimes called 'l'homme nouveau'. This blueprint of the 'new man' brought about a dramatic the rupture with the figure of the Old Regime subject. But as the revolution unfolded many revolutionaries struggled with the tension that lay at the heart of the concept of regeneration: if the declaration of the rights of man and citizen had proposed the rebirth of man, why did the reborn man still require regeneration? Ozouf and De Baecque have distinguished two visions of regeneration, one quasi-religious, millenarian view presupposing the sudden 'miracle of a new birth', and another more 'laborious' type of regeneration that requires strict education, coercion and, above all, patience. ${ }^{40}$

Against this background, the idea of a gradual emancipation or régénération of black slaves and non-western peoples into citizens was widely considered to be a commendable course of action throughout the Atlantic world, although the time paths, practical implementation, and the precise nature of such programs varied considerably. Such emancipation programs naturally rested on a (temporary) differentiation of citizenship within the polity. Distinctions were drawn between full, second class, or even more stripped-down notions of citizenship according to the level of civilization of the empire's inhabitants. In response to the Haitian Revolution, when the question of the scope of equal rights and citizenship was posed in such a radical way, this discourse was

38 The formulation of the question is Sepinwall's. Sepinwall, The Abbé Grégoire and the French Revolution, p. 91.

39 C.F. Reinhard, Le Néologiste français, ou vocabulaire portatif des mots le plus nouveaux (Nurnberg: Grattenaver, 1796). As cited in : A. de Baecque, Le corps de l'histoire. Métaphores et politique (1770-180o) (Paris: Calmann-Lévy, 1993), p. 168.

40 De Baecque, Le corps de l'histoire; M. Ozouf, L'homme régénéré: Essais sur la Révolution française (Paris: Gallimard, 1989); See also Ozouf's entrance on 'Regeneration' in: Furet and Ozouf (eds.), A Critical Dictionary of the French Revolution. 
deliberately invoked on a transatlantic scale to delineate one's political community of citizens.

\section{Unity and Hierarchy in the French Empire}

In their address to the French Legislative Assembly in November 1791, a delegation of colonial planters and deputies of Saint-Domingue offered their account of the situation in Saint-Domingue. Unsurprisingly, it was highly coloured. They pictured the actions of the insurgents as 'scenes of African atrocities' and acts of 'barbarism', and painted the gruesome scene of revolting slaves holding 'as a banner the cadaver of a white child impaled upon the end of a pike'. This image, possibly made-up, would be replicated throughout the Atlantic. ${ }^{41}$ The delegates suggested that slaves in the Caribbean were actually better off than when they had stayed in Africa, 'without political existence, without civil existence. This was a mainstay of the proslavery argumentative arsenal. They also praised the 1789 Declaration of the Rights of Man and Citizen. The document was no doubt 'salutary for hommes éclairés (enlightened men)', but inapplicable to slaves who are 'incapable of enjoying their liberty wisely'. ${ }^{2}$ From the moment they set foot on French soil to tell their side of the story, they framed the insurrectionists as unenlightened, dangerous savages who could only be controlled by re-imposing a strict hierarchy governed by 'enlightened men'.

In the following months and years, France saw an outburst of publications of eyewitness accounts of the insurrection, many of which, according to Jeremy Popkin, 'cast the violence in Saint-Domingue as a stark, racialized confrontation between civilized whites and barbaric enemies', although a small number of accounts described the black insurgents in more humane terms. ${ }^{43}$ The main accusation white planter class and their representatives flung at the Société des Amis des Noirs was that they were responsible for the colony's ruin. More or less denying the agency of black insurrectionists, they argued that the philosophical ideas of these 'philanthropists' had spurred black slaves into action.

In their turn, members of the Société des Amis des Noirs accused white planters not only of being stubborn, self-interested conservatives who threatened the survival of the colonial empire, but also of being counterrevolutionaries contesting the nation's supreme and undivided authority. Under the leadership of the prominent Jacobin Brissot, members and former members of the

$41 \quad A P$ 35, p. 461; Dun, Dangerous Neighbors, pp. 56-57.

$42 \quad A P_{35}$, pp. 464-465.

43 Popkin, Facing Racial Revolution, pp. 9, 25. 
Société des Amis des Noirs had become more dominant in the Legislative Assembly, although the society itself fell apart in late 1791 . They eagerly sought to counter the account promulgated by the white planter class, and the tide of public opinion was turning in their favour. A representative example is the speech addressed to the Legislative Assembly on February 29, 1792, by the Parisian lawyer and representative Jean-Philippe Garran-Coulon. Indicative of the change in the climate of opinion that had occurred over the preceding months was that, according to the day-to-day records, Garran-Coulon's speech prompted applause at several moments and motivated a number of deputies to request printed copies of it afterwards (although the speech was actually read in his absence). ${ }^{44}$ Excerpts and fragments of Garran-Coulon's speech were translated into English to be appended to the English abolitionist Thomas Clarkson's An Inquiry into the Causes of the Insurrection of the Negroes in the Island of St. Domingo, which was widely distributed by the Pennsylvania Abolition Society. Garran-Coulon's translated speech even appeared in a series spread over several days in the Philadelphia newspaper Dunlap's American Daily Advertiser in July $1792 .{ }^{45}$

The first view Garran-Coulon set out to rectify was the allegation that the revolt by people of colour and the slave insurrection were products of some 'conspiracy' machinated by the Société des Amis des Noirs and their 'philosophical writings'. Instead, he claimed that it had resulted from the 'perpetual injustice' of slavery and the 'civic degradation' of people of colour. Just 'like the Génevois, Avignonnais, and Liégois, the people of colour wanted to be free', Garran-Coulon argued. But the white planter class had refused to implement the decree of 15 May and chose war. Amidst these bloody scenes, how could

44 'Lecture du discours de M. Garran-de-Coulon' read by M. Guadet. AP 39 (February 29, 1792), pp. 209-220.

45 Garran-Coulon's speech appeared as an appendix to T. Clarkson, An Inquiry into the Causes of the Insurrection of the Negroes in the Island of St. Domingo. To which are added, Observations of M. Garran-Coulon on the same Subject, read in his Absence by M. Guadet, before the National Assembly, 29th Feb. 1792 (London: Johnson, 1792). This pamphlet was distributed by the Pennsylvania Abolition Society and the British Society for Effecting the Abolition of the Slave Trade. For this, see Oldfield, Transatlantic Abolitionism in the Age of Revolution, p. 97. It was printed (spread over seven editions) in the Dunlap's American Daily Advertiser (Philadelphia, Pennsylvania) between 6 and 23 July 1792. It was not the last time that Garran-Coulon would address the situation in Saint-Domingue. In 1797-1798 he would publish a 2000 page long, four-volume report on 'the troubles of Saint-Domingue' on behalf of the Colonial Committee, which modern historians still deem an essential primary source on the Haitian Revolution. J.P. Garran-Coulon, Rapport sur le troubles de Saint-Domingue, fait au nom de la Commission des Colonies, des Comités de Salut Public, de Législation, et de Marine, réunis, 4 vols. (Paris: Imprimerie nationale, An V [1797-1798]). 
the negroes not reflect on their extreme misery and intolerable debasement, on their incontestable rights and formidable number, and on the divisions between their masters?', Garran-Coulon asked. The only ones responsible for the revolt were the French planters themselves, the men who were 'accustomed to despise their fellow men' and 'hold them in most brutal slavery'. By refusing to implement the decree of May 1791 the white planters in Garran-Coulon's eyes essentially had put limits to the sovereignty of the nation, by contesting its supremacy and unity'.46

After all, 'did not the same colonial deputies and their audacious partisans utter everywhere the threat of separation like a spectre, while boasting the example of the United States?'47 But Garran-Coulon turned the parallel that was sometimes drawn between white settlers claiming colonial independence for Saint-Domingue and their bigger New World neighbour's struggle for independence upside down. In a clever rhetorical stroke, repeating a denunciation against the planters that was filed earlier in December 1791 by Brissot, GarranCoulon identified the deeds of white planters as a 'counterrevolution' undertaken by 'antipatriotic confederations' formed at the island. ${ }^{48}$ Above all, he insisted that

the disastrous effects of so much weakness, and of the omission of all principles upon which our liberty is based, must teach us a lesson. They show us simultaneously the cause of the tragedy of Saint-Domingue and the appropriate measures to solve it. They teach us that we never ought to allow any infringements to be made on the national sovereignty, and even less still on the eternal rights of nature and reason; that palliatives can no longer be used; that the lack of energy on our part will perpetuate the misfortunes of the colonies; that it will consume the white planters themselves, as they persist in foolish preservation of their pride up to the point of their complete destruction; that, finally, all the authority the nation has handed down to us is to be exerted in order to save [the colonies] despite of themselves, and naturalize in these lands, if for a long time defiled by the violation of all rights of humanity, the great principles of justice, which must henceforth be inseparable from the French law. ${ }^{49}$

46 Garran-Coulon, 'Lecture', $A P$ 39, pp. 210-211, 216.

47 Garran-Coulon, 'Lecture', $A P$ 39, p. 211.

48 Ibid.

49 Ibid., p. 212. 
The risk of colonial secession, then, imperilled not only France's economic interests and symbolic power as an Atlantic empire, but also thwarted the endeavours of such prominent revolutionaries as Brissot, Condorcet, the Abbé Grégoire, and Garran-Coulon. They attempted to carry through what they saw as a universal revolutionary project, a project which proclaimed within the French empire civic and political equality to all free men regardless of their colour. In that sense, the ways in which revolutionary discourse was put to use by, on the one hand, North American revolutionaries during the 1770s and 178 os and, on the other hand, egalitarian French revolutionaries during the 179os, had reversed. Whereas American revolutionaries had fought a righteous cause, invoking the notions of the rights of man and national sovereignty so as to legitimize their break-up from the British Empire, French revolutionaries like Garran-Coulon invoked the rights of man in order to keep Saint-Domingue within the French empire so as to guarantee the constitutional unity of one political community.

Those who deployed this logic of an indivisible universal empire ignored the de facto hierarchical subordination of potentially self-determining political communities (within the empire). From Garran-Coulon's point of view this was unproblematic, since 'the incorporation of diverse parts of the Empire and the duration of the social contract' have for both these integrated parts and for individuals 'a solid and just foundation in common utility'. American independence and the French model of imperial assimilation were two sides of the same coin:

The American Revolution and ours [...] are only the forerunners of a universal renovation of all political institutions, are already dedicated to this great principle: the one through its separation from the mother country, the other through the decrees on Alsace, the abolition of privilege in all provinces, and through the access of the state Avignon into the realm. ${ }^{50}$

For Garran-Coulon and his allies there was no conflict between universalism and imperial assimilation, whether in the case of Alsace, Avignon, or Saint-Domingue.

Garran-Coulon thus made the case that order in the colonies could only be restored, and moreover, the promise of the rights of man and citizen could only be fulfilled, through the interventions and efforts of a metropolitan-based political elite. This strategy was premised on the idea that the colonies are 'expressément part of the French empire, and consequently, of the nation'. An

Garran-Coulon, 'Lecture', $A P$ 39, p. 213. 
'enlightened nation', after all, 'invests her ambition more in the propagation of principles than in the extension of her power. ${ }^{51}$ In line with the great French tradition of bombastic revolutionary rhetoric, Garran-Coulon called upon his colleagues to 'expand the empire of liberty and justice' and invited everyone 'to join us to contemplate in the temple of equality over the means to assure the happiness and liberty of all members of the French empire..52

Despite this universalist rhetoric, Garran-Coulon and his fellow ex-Amis des Noirs maintained that a French constitutionally unified empire should be governed by a civilizational hierarchy. In their view, the task, or as it would be called in the nineteenth century, the 'mission civilisatrice', was to ameliorate the condition of slaves and regenerating the 'uncivilized' so as to make them fit for republican citizenship. This task was best secured in the hands of a metropolitian based political elite at the centre of power. ${ }^{53}$

The lesson drawn from the opposition of Saint-Domingue colonial political elites to granting free men of colour equal rights made abundantly clear that this task could not be entrusted to them. Accordingly, as Marcel Dorigny has rightly underscored, the 'doctrine' of the Société des Amis des Noirs was abolitionist, but by no means 'anti-colonialist' (as we will see, this applies to Dutch antislavery revolutionaries too).${ }^{54}$ Instead, their agenda consisted of a redefinition of the notion of citizenship within the framework of a colonial (and from August 1792 onward: 'republican') empire. It did not imply a first step from Atlantic empire to nation-state. It was, rather, an attempt to make the French empire compatible with the ideals of the French revolution.

This vision was concisely summarized by Antoine-Jean-Thomas Bonnemain in his pamphlet Régénération des colonies published in March 1792: 'According to the declaration of the rights of man, all individuals that constitute the empire must be citizens; their rights are guaranteed by the constitution'.55 But he immediately added that this eternal principle cannot for the moment be

$51 \quad$ Garran-Coulon, 'Lecture', $A P$ 39, p. 214.

52 Ibid., p. 213.

53 On the inellectual background of this 'mission civilisatrice', see P. Røge, 'l'Économie politique en France et les origines intellectuelles de 'la mission civilisatrice' en Afrique', Dixhuitième siècle 44 (2012), pp. 117-130.

54 M. Dorigny, 'La société des amis des noirs et les projets de colonisation en Afrique', Annales historiques de la Révolution française 293-294 (1993), pp. 421-429; M. Dorigny, 'Intégration républicaine des colonies et projets de colonisation de l'Afrique: Civiliser pour émanciper?', in: Dorigny and Bénot (eds.) Grégoire et la cause des noirs, 1789-1831, pp. 89107. Cf. F. Gauthier, [review] Yves Bénot, 'La Révolution française et la fin des colonies', Annales historiques de la Révolution française 271 (1988), pp. 491-493.

Bonnemain, Régénération des colonies, pp. 95-96. 
applicable [...] to persons that are not at liberty.56 Bonnemain's pamphlet had been successfully blocked by the white planter lobby in Paris for two years. In the supplement Bonnemain added to the 1792 publication addressing the current situation, he explicated that 'unfree people' ought to be considered as 'minors under the tutelage of the government'. The law should only gradually improve their 'civil and political state'. ${ }^{57}$

Such visions of the French empire had been articulated earlier by amongst others Condorcet and Henri Grégoire. ${ }^{58}$ They revealed not only a 'new' civilizational hierarchy but also a program of what Bonnemain called 'la régénération de l'espèce humaine. The basic belief was that black slaves due to their uncivilized and unenlightened mental and moral condition were not yet eligible for the duties and rights that come with modern citizenship. They had to be 'regenerated' in order to be admitted to a uniform civic community. Bonnemain's Régénération des colonies too passionately defended the decree 'to accord [...] the quality of citizen' to Saint-Domingue's free people of colour. In the same breath, however, he proposed to '[s] uppress the shameful name slave, [and] replace it'. Not by the title of citizen, but by 'the interesting name of pupil'. ${ }^{59}$

The Société des Amis des Noirs was incessantly accused of inciting the rebellion, mostly by conservatives and spokesmen of the planter's class. But radical revolutionaries who were overall sympathetic to the aims of the Société des Amis des Noirs too could be heard expressing feelings of disenchantment in the wake of the slave insurrection. ${ }^{60}$ The reaction of the renowned defender of both women's, coloured and black people's rights Olympe de Gouges, for instance, unambiguously depicted the black insurgents' acts as 'savagery'. In a new preface written in 1792 to her theatre play L'esclavage des noirs ou l'heureux naufrage (Black Slavery, or the Happy Shipwreck), which was originally staged in 1789 , De Gouges's response to the slave insurrection was imbued with a sense of disappointment. Explicitly addressing black slaves and men of colour, she lamented that 'Men were not born in chains, yet you prove that they are necessary'. ${ }^{61}$ Praising 'social order' and the 'wisdom of law', De Gouges warned that 'if the savage, a ferocious man, fails to recognize this Law, then he is made

$56 \quad$ Bonnemain, Régénération des colonies, p. 77.

57 Bonnemain, 'Supplement', in: Régénération des colonies, pp. 104-105.

$5^{8}$ M. Schwartz [Condorcet], Réflexions sur l'esclavage des nègres (Neufchâtel: Société typographique, 1781); Sepinwall, The Abbé Grégoire and the French Revolution, p. 96.

59 Bonnemain, Régénération des colonies, p. 77 (italic in original).

6o Cf. Dubois, Avengers of the New World, pp. 105-106.

61 O. de Gouges, L'esclavage des noirs, ou l'heureux naufrage (Paris: Duchesse, 1792). Translation taken from 'Preface' to The Slavery of Blacks, in: Dubois and Garrigus (eds.), Slave Revolution in the Caribbean, p. 109. 
for irons, to be tamed like a brute'. De Gouges's cautious hope that her France, 'an enlightened nation', 'was not mistaken to treat you like men and give you rights that you never had in America' echoed the Abbé Grégoire's earlier rendering of the extension of 'universal' rights to free people of colour as a gift from the enlightened mother country to the oppressed man. This precious gift could be taken away if they did not live up to the expectations of an 'enlightened nation'.

Such reflections show that the Société des Amis des Noirs and other advocates of gradual abolition in revolutionary France were caught up by events. Their interventionist strategy granting free people of colour equal rights as the only viable course of action to contain and put an end to the slave revolt in the end carried the day. But it was accompanied by a series of restatements that black slaves were not eligible for citizenship in an empire that they so passionately defended as a constitutionally unified polity.

The image of a once wealthy and orderly colony racked by horrific violence and devastation also came to dominate American media. ${ }^{62}$ The reports, oral communications, and refugees coming from Saint-Domingue between late 1791 and 1794 arrived at a critical transitional stage in the emergence of rival interpretations of the French Revolution. Whereas initially the American public generally interpreted the French Revolution as a confirmation of their own revolution, the king's flight to Varenne in June 1791, his deposition and the founding of the French Republic in August and September 1792, the September massacres, the execution of Louis XVI in January 1793, the declaration of war against Britain the following month, and the coming of the Terror generated highly politicized and conflicting interpretations of the course the French Revolution had taken.

Democratically-minded Americans, dissatisfied with what was in their view still a system of elite politics, welcomed the egalitarian spirit of the French Revolution as heralding a new phase in the unfinished transformation of

62 The stream of literary representations of the 'horrors of Saint-Domingue', as Matt Clavin has argued in a fascinating article, also contained elements of sensationalism and entertainment, 'blurring the line of fiction and nonfiction', and drawing on the popular Gothic genre that authors and publisher tried to exploit in a 'competitive literary marketplace'. M.J. Clavin, 'Race, Revolution, and the Sublime: The Gothicization of the Haitian Revolution in the New Republic and Atlantic World', Early American Studies: An Interdisciplinary Journal 5 (2007), pp. 1-29. 
American politics and society. In their eyes, there were still remaining aristocratic elements to be eliminated; the American Revolution was not finished, its promises not yet fulfilled. Federalists, on the other hand, conscious that the new American Republic was in many ways a fragile experiment, wanted the constitution to be a framework for harmonious government and a bulwark against popular democracy. ${ }^{63}$ Although for a time Federalists were sympathetic to a revolution that reminded them so much of their own, they soon came to follow the outburst of domestic popular enthusiasm for the more democratic 'sister republic' with growing concern. Well before news of the Terror would reach the shores of the American Republic, Federalists already nourished a deep suspicion of the democratic forces the French Revolution seemed to unleash.

While American reflection on both Saint-Domingue and the Terror took place within the context of an emerging political partisanship between Federalists and Republicans, it is important to realize that the very notion of partisanship, opposition or faction, ran counter to deeply held ideals of an undivided political body and the belief in one identifiable common good. ${ }^{64}$ The quarrels between Federalists and anti-Federalists in the second half of the 178 os over the ratification of the new constitution were hardly compatible with the Federalist ideal of an orderly and united republic. Hence there was a strong desire that the newly accepted constitution would announce - and come to symbolize - a definite closure of a political culture of public disagreement and civic conflict. Yet the opposite happened. Already in 1790, discontented Virginian politicians, most prominently the congressional leader James Madison and Secretary of State Thomas Jefferson, began to oppose Secretary of the Treasury Alexander Hamilton's program of centralized state building and strengthening of the national government. Hamilton's financial proposals for the establishment of a national bank and for the federal government's assumption of the debts of individual states would in the eyes of Jefferson and Hamilton unduly favour the northern states and their commercial interests. Their opposition to Hamilton's policies and the government administration led to the formation of a loose coalition of likeminded critics that would come to be known as 'Republicans'. Initially, Republicans had their stronghold in southern states, an

63 W. Holton, Unruly Americans and the Origins of the Constitution (New York, N.Y.: Hill and Wang, 2007); T. Bouton, Taming Democracy: 'The People', the Founders, and the Troubled Ending of the American Revolution (Oxford: Oxford University Press, 2007).

64 J.R. Sharp, American Politics in the Early Republic: The New Nation in Crisis (New Haven, CT:Yale University Press, 1993), pp. 8-10. See also, R. Hofstadter, The Idea of a Party System. The Rise of Legitimate Opposition in the United States, 1780-1840 (Berkeley, CA: University of California Press, 1972), pp. 40-73. 
overwhelmingly rural world that depended economically on plantations making use of black slave labour. Southern Republicans opposed the vision of a strong, centralized government, and cherished the ideal of the independent, rural, landowning (white male) citizen. Over the course of the 1790s, however, in the northern states the popular anti-establishment rhetoric of the Republican opposition came to attract increasing numbers of yeoman farmers and ambitious urban middleclass people discontent with Federalist elites. ${ }^{65}$

The supporters of the national government's policies were known as the 'Federalists', a label that was appropriated from those who advocated a national constitution in the late 178 os. The Federalists had their stronghold in the more urbanized northern states that were economically based on trade and commerce. ${ }^{66}$ The Federalist persuasion was much more steeped in a deferential and hierarchical vision of politics: a strong centralized bureaucratic government ought to be in the hands of elites at a distance from ordinary citizens and public opinion. They were regularly accused by Republicans of being monarchists in disguise, intent on setting up a monarchical government modelled on England and betraying the principles of the revolutionary republicanism of the 1770 . Federalists, in turn, saw Republicans as popular agitators and unruly democrats. Neither were organized like modern, political parties. Rather, as historian James R. Sharp put it, 'these designations were generic terms of advocacy, public labels that signalled endorsement of certain principles'. ${ }^{67}$ News of the events in Saint-Domingue would arrive in this increasingly polarized public sphere and political climate.

American newspapers of late 1791 and early 1792 typically related of 'acts of most shocking cruelty', 'the cruelty of savages', and 'barbarous massacres'. 68 The Boston leading Federalist newspaper Columbian Centinel, reproduced the image of the 'standard borne by the insurgents [...] a white child impaled upon

65 J.O. Appleby, Capitalism and a New Social Order: The Republican Vision of the 1790 (New York: New York University Press, 1984); L. Banning, The Jeffersonian Persuasion: Evolution of a Party Ideology (Ithaca, N.Y.: Cornell University Press, 1978); R. Buel, Securing the Revolution. Ideology in American Politics, 1789-1815 (Ithaca N.Y.: Cornell University Press, 1972).

66 Buel, Securing the Revolution. Although the Federalists had their stronghold in northern states and Republicans in southern states, national politics was not sharply divided between a Federalist commercial North (or New England) and a republican agrarian South. There were numerous mercantile Republicans in the North and agrarian Federalists in the South.

67 Sharp, American Politics in the Early Republic, p. 9.

68 The New-York Journal, \& Patriotic Register (New York, New York), September 28, 1791; The New-York Journal, \& Patriotic Register (New York, New York), October 15, 1791; Claypoole's Daily Advertiser (Philadelphia, Pennsylvania), January 2, 1792. 
a pike, a piece of barbarity worthy of such savages'.69 Admittedly, sporadic comments American newspapers omitted or toned down the alleged savagery and instead highlighted the injustice of slavery, the motives for insurrection, or the remedies to put the disturbances to an end. One New York newspaper, for instance, contended that the exclusion of free people of colour and free blacks from citizenship was in fact 'one of the causes of the disturbances in that unfortunate colony', and that the solution to the troubles should at any rate consist of 'a re-election of the colonial and other popular assemblies of the island, in which free people of colour and negroes will have voices.' ${ }^{70}$

Yet on the whole, the general picture of the island was bleak. From within Saint-Domingue, Nathaniel Cutting anticipated in one of his many letters to Secretary of State Jefferson that news 'of the horrid devastation' had probably already reached him. ${ }^{71}$ Cutting's letters to Jefferson, many of which were circulated in government circles and some of which were printed (and copied) in several newspapers, testify to the shifting appraisal of revolutionary France in light of the events of Saint-Domingue. Cutting supposed that the colonial 'French Aristocrates' [sic] who were hoping for a counterrevolution in France could be partly held responsible for the colony's ruin, accusing them of being 'stimulators and abettors of all the horrid proceedings'. But on a more ideological level, Cutting attributed the chaos and anarchy to the excrescences of the 'leveling [sic] principles' of revolutionaries 'in France \& elsewhere'. The 'infernal transactions' that were taking place on the island, Cutting suggested, 'are only the ebullitions of uncultivated spirits which have made a sudden transition from the extreme of ignorance and despotic restraint, to certain mistaken ideas of the Rights of Man and that unbridled licentiousness consequent thereto'. ${ }^{72}$ In a subsequent letter dated April 13, 1792, that would be printed in the (Republican) National Gazette and the New-Jersey Journal, Cutting averred that the island's free people of colour and black slaves were infected by 'specious opinions [...] which have been so industriously disseminated by some impolitic pretenders to philanthropy' ${ }^{73}$ Such allegations laid the building blocks for the view that French 'levelling principles' were wrongly and naively

69 Columbian Centinel (Boston, Massachusetts), February 18, 1792.

$70 \quad$ The Diary or Loudon's Register (New York, New York), October 11, 1792.

71 Cutting to Jefferson, 29 November 1791, PTJ.

72 Nathaniel Cutting to Thomas Jefferson, 28 December 1791, PTJ; Cutting, Journal, 1 December 1791, as cited in: Newman, 'American Political Culture and the French and Haitian Revolutions', p. 79 .

73 Cutting to Jefferson, 13 April 1792, PTJ. The letter appeared in the National Gazette (Philadelphia, Pennsylvania) of May 7, 1792, and the New-Jersey Journal (Elizabethtown, New Jersey) of May 16, 1792. 
applied to a population that was portrayed as too 'uncultivated' for emancipation.

Similar to the accounts of Paulus and Kluit, one of the common tropes used in American newspapers to describe the lack of civil order in Saint-Domingue was 'anarchy' - often in combination with the notion of a 'return' to a state of 'wilderness'. Some of these comments displayed a similar reasoning that such 'savages' were not to be emancipated immediately. As an article in the New York Daily Advertiser put it: 'Brutal and savage men know no medium between the most abject slavery and the most licentious tyranny. The emancipation of slavery in the West Indies should be gradual, just as it was in Europe - where it was accomplished by the progressive influence of religion, humanity, and commerce, rightly understood. ${ }^{74}$ Cutting added his voice to this choir, writing that the 'bloody Banner of Anarchy' will 'long continue display'd' if the insurgents whom he regularly described as 'savage banditti' or 'remorseless savages', would not be crushed. ${ }^{75}$ It only strengthened the preconceived conceptions of slaveholding men such as Jefferson. In a letter to his daughter Martha predating the 1791 insurrection, Jefferson had sounded a similar theme, writing that the islands in the West Indies, 'most particularly St. Domingue and Martinique', were involved in a 'horrid civil war' and that the inhabitant's slaves were 'absolutely ungovernable. ${ }^{76}$

Such responses to this phase of the Haitian Revolution coincided with and mutually invigorated the initial responses to news of the radicalization and violence of the French Revolution. From late 1792 onwards, American newspapers of mostly but by no means exclusively Federalist signature began to report 'excesses' in Paris springing from the 'rage of the populace. ${ }^{77}$ Readers of both the Republican National Gazette, and the more Federalist-leaning Connecticut Journal and New-Hampshire Gazette, learned that the 'fatal 2d of September' was the work of a 'sanguinary mob'. ${ }^{78}$ Such alarming news from France made many Americans aware that the French Revolution had entered a new phase. 'This country continues to be drenched in blood', a comment printed in (both Federalist and Republican) Massachusetts and Vermont newspapers stated in November 1792. 'And the genius of this once polished people, seems to suffer a

74 The Daily Advertiser (New York, New York), January 19, 1792.

75 Cutting to Jefferson, 21 January 1792, PTJ; Cutting to Jefferson, 1 March 1792, PTJ.

76 Jefferson to Martha Jefferson Randolph, 24 March 1791, PTJ.

77 The North-Carolina Journal (Halifax, North Carolina), November 28, 1792.

78 National Gazette (Philadelphia, Pennsylvania), November 14, 1792; Connecticut Journal (New Haven, Connecticut), November 14, 1792; New-Hampshire Gazette (Portsmouth, New Hampshire), November 21, 1792 . 
gradual deterioration; their cruelty exceeds belief, and they every day give new and shocking proofs of their ingenious barbarity.' ${ }^{79}$

The theme of mob violence figured prominently in these first comments, but those favourably disposed to France's revolution believed it to be a lamentable but necessary means to achieve a greater cause that was connected to their domestic situation. In late December 1792, for example, the National Gazette, the foremost Republican newspaper of the early 179os set up by Madison and Jefferson in 1791 to reach a nationwide audience, attacked the Federalist Vice-President John Adams for recommending 'hereditary monarchy' and 'aristocracy'. In the same article, it praised French Jacobins for loosing 'the shackles of slavery of thirty millions of people' and for contributing to the 'emancipation of the human race. ${ }^{80}$ In June 1793, the same National Gazette, as well as the more radical-democratic Boston Argus, printed the series of articles (spread over several issues) 'Cool Reflections relative to the French Revolution' by 'Philadelphus'. The author (National Gazette's editor Philip Freneau himself, according to the Boston Argus), urged 'every American to consider the struggles of France as a continuation of the glorious struggles of his own country'. The dethronement of Louis XVI on August 10, 1792, although 'attended with violence, convulsion and blood' and although it could 'easily be disfigured into a picture of horror, and a sad example of popular government' was 'a necessary and wise, as well as a justifiable measure. ${ }^{81}$ The revolutionary violence was, thus, interpreted as an aberration, not as an essential outcome of political principles or the lack of moral uprightness on the part of the French people. As one New Jersey newspaper lamented: 'some horrid cruelties have been perpetrated, by lawless and savage mobs [...] which none but aristocrats and monarchical men will dare to impute to the French as a Nation'.82

In these feuds over the assessment of revolutionary France, Saint-Domingue became another battleground for the evaluation of French universalism and popular violence. Thomas Paine's Rights of Man offered a vocabulary to reshape antislavery discourse into a trans-Atlantic struggle against oppression. 'Nature gave the African rights, of which he cannot be divested without an act of injustice', 'A Friend to the Rights of Man' proclaiming to be living in an

79 Western Star (Stockbridge, Massachusetts), November 20, 1792; Vermont Gazette (Bennington, Vermont), November 30, 1792.

8o National Gazette (Philadelphia, Pennsylvania) December 26, 1792.

81 The Argus (Boston, Massachusetts), June 18, 25, 26, 1793. National Gazette (Philadelphia, Pennsylvania), June 5, 8, 19, 22, 1793. The Argus identified the National Gazette's editor-inchief Philip Freneau as the author of the articles.

82 The New-Jersey Journal (Elizabethtown, New Jersey), May 8, 1793. 
'enlightened age' wrote in the National Gazette. ${ }^{83}$ Other voices, such as the lawyer and publicist Theodore Dwight, justified the violence on Saint-Domingue in a way similar to the justifications that were given for the violence in the French metropole. In an oration for the Connecticut Abolition Society, Dwight called upon his fellow citizens to turn their attention to Saint-Domingue, where 'ideas of freedom and slavery' had 'taken stronghold of the negroes'. Dwight felt no need for concealing the 'desolation and blood over the face of the colony'. He implied, however, that such evils 'necessarily attend such convulsions of liberty' and are inevitable in order for the insurgents to establish themselves 'on the firm pillars of freedom and independence'. ${ }^{84}$ These antislavery radicals such as Dwight, Abraham Bishop (Chapter 2), or the Kentucky Presbyterian minister David Rice, however marginal, called out for solidarity with the black insurgents and advocated a model of equal citizenship, embedding it in a trans-Atlantic revolutionary context.

On the proslavery end of the spectrum, responses to the slave insurrection were shot through with an increasing abhorrence and consequently a rejection of what was seen as 'French' philosophical radicalism. Condemnations of, and dissociations from, what was often depicted as a French 'experiment' in the colonies became widespread. 'In fact', one South-Carolina commentator stated, 'Brissot and his factious friends in the convention [...] certainly are the principal authors of all the horrors committed in St. Domingo', ${ }^{85}$ American newspapers from slaveholding states printed virulent op-ed articles relating 'Jacobin' radicalism to the civic emancipation of black and coloured people. Particularly telling is a piece in Charleston's Columbian Herald or the Southern Star of December 5, 1793, written by someone under the pseudonym 'MONITOR'. The author indicted the Second Civil Commission that had landed in Cap Français in September 1792 and were originally instructed to enforce the decree of April 4, 1792, but eventually issued a proclamation of general emancipation that included black slaves in August 1793. These 'agents, who now support and decorate the French system',

are the favorites and followers of Danton, Robespierre, Brissot, and Marat [...] Sonthonax, Polverel, and other emissaries received their mission from their Jacobin creators - Go said their masters [...] Subject the world

$83 \quad$ National Gazette (Philadelphia, Pennsylvania), December 26, 1792. This op-ed article was copied from the Augusta Chronicle.

84 T. Dwight, An Oration, spoken before the Connecticut Society, for the Promotion of Freedom and the Relief of Persons unlawfully holden in Bondage (Hartford, CT: Hudson and Goodwin, 1794). See also Abraham Bishop's series of articles discussed earlier (n. 11).

85 The City Gazette \& Daily Advertiser (Charleston, South Carolina), November 26, 1793. 
to the Jacobins of France [...] we give you the secret of revolution and the spoils of devastation [...] sow dissention \& create discord [...] and bring those of desperate fortunes, mobs and others, with the charms of promised equality. [...] The massacre being over, the city burnt, the plate and monies collected for the service of the republic, the business done, your mission is fulfilled, sing ca ira, Vive la Republique. ${ }^{86}$

Such commentators looked upon the Jacobins' 'charming' promise of equality with fear. As Thomas Jefferson wrote to then Senator James Monroe in the Summer of 1793, he was becoming 'more and more convinced that all the West India islands will remain in the hands of the people of colour, and a total expulsion of the whites sooner or later take place'. It was 'high time we should foresee the bloody scenes which our children certainly, and possibly ourselves $[\ldots]$ have to wade through, and try to avert them.87 ${ }^{8}$ Such evaluations stood at the basis of a conclusion that would gradually replace the initial expressions of cosmopolitan enthusiasm and feelings of universal brotherhood: the French revolutionary project of citizen emancipation was at odds with theirs.

86 Columbian Herald or the Southern Star (Charleston, South Carolina) of December 5, 1793. Abstracts of the proclamation had appeared in, among others, The Federal Gazette and Philadelphia Daily Advertiser (Philadelphia, Pennsylvania), October 15, 1793.

87 Jefferson to James Monroe, July 14, 1793, PTJ. 


\section{The Turn Away from French Universalism}

In late January 1794 a remarkable delegation of three Saint-Domingue deputies arrived in Paris: Louis Dufay, a French-born white planter; Jean-Baptiste Belley, a formerly enslaved black army officer; and Jean-Baptiste Mills, a free coloured man. Despite considerable opposition from the white planter lobby, the 'tricolor' delegation secured seats in the National Convention as representatives of Saint-Domingue's Northern Province. After a powerful speech by Dufay on February 3, the Montagnard-dominated National Convention declared the following day that 'the slavery of negroes is abolished in all colonies; consequently, it decrees that all men living in the colonies, without distinction of colour, are French citizens and enjoy all the rights guaranteed by the constitution. The decree was undeniably a major feat: for the first time a national representative body of a major slave-holding Atlantic empire officially decreed the abolition of slavery. Celebrations in the Notre Dame (that had been turned into a 'Temple of Reason') and elsewhere in France were accompanied with speeches that were multiracial and universal, at least in spirit. In the following months and years, on more than one occasion, voices in France could be heard praising Saint-Domingue's black citizens as capable and courageous, and being worthy of their French citizenship. ${ }^{1}$

Yet the momentous expansion of citizenship within the French colonial empire was also short-lived, politically fragile, and ideologically muddled. ${ }^{2}$ While the revolutionary momentum of the early 1790 os had inspired many radical egalitarian revolutionaries to imagine models of equal imperial citizenship within a single constitutional order, the decree of 16 pluviôse an II (February 4 , 1794) abolishing slavery and assigning French citizenship to black slaves within the French empire was neither a direct result nor a straightforward victory of a universalist ideology proclaiming liberté and égalité. ${ }^{3}$ At the time of the voting

1 Dubois, Avengers of the World, pp. 168-170.

2 Cf. M.F. Spieler, Empire and Underworld: Captivity in French Guiana (Cambridge, MA: Harvard University Press, 2011), pp. 38-52.

3 Popkin, You are all Free, esp. ch. 10. See however, Piquet, Lémancipation des Noirs dans la Révolution française: 1789-1795. See also Y. Bénot, 'Comment la Convention a-t-elle voté l'abolition de l'esclavage en l'an II ?', Annales historiques de la Révolution française 293-294 (1993), pp. 349-61. 
in the National Convention, the Société des Amis des Noirs (which had always rejected immediate emancipation) had ceased to exist. Condorcet had gone into hiding; Julien Raimond was imprisoned; Brissot beheaded. The abbé Grégoire would later confess in his memoirs that at the time the 'sudden emancipation' had seemed 'disastrous' to him. ${ }^{4}$

In addition, despite of the fact that the 1794 emancipation decree was reconfirmed in the Thermidorian constitution of 1795 as well as in the 1798 'Law on the Organization of the Colonies', the actual implementation of the decree throughout the French empire was only carried through to a limited extent. ${ }^{5}$ The decree of 1794 never took effect in Martinique which was only returned to France by the Treaty of Amiens in 1802, while the white planters of Île de France (Mauritius) and Île Bourbon (La Réunion) successfully refused to implement it. In Saint-Domingue, slavery was in fact already abolished; the National Convention only confirmed it. Technically speaking, in February 1794 France was ruled by a 'revolutionary government', the implementation of the 1793 constitution postponed. Under these circumstances, as Miranda Spieler has argued, the status of new imperial law was highly uncertain. ${ }^{6}$

Robespierre's record on the issue of abolition, as well as that of other Montagnards, was, moreover, ambiguous. ${ }^{7}$ The purge of the Girondins in May-June 1793 was praised by the white planter class who for a time stood side by side with the Montagnards. Among Montagnards the burning of Cap Français in June 1793 was widely seen as a 'Brissotin' conspiracy. In July, the National Convention had even ordered the civil commissioners Sonthonax and Polverel to return to the metropole so as to put them on trial. In the conspiracy-ridden and deeply antagonistic political climate of 1793-1794, the dominating Montagnard faction, absorbed in strategic wrangling and internal strife, did not pursue a consistent abolitionist program. ${ }^{8}$

If the February 1794 decree was at best a mix of idealism, (military) opportunism, and revolutionary symbolism, in the United States and the Dutch

4 H. Grégoire, Mémoires de Grégoire, ancien évêque de Blois (Paris: A. du Pont, 1837), p. 391.

5 On the law of 1798 , see B. Gainot, 'La naissance des départements d'Outre-Mer. La loi du 1er janvier 1798', Revue d'histoire des Mascareignes et de l'Océan Indien 1 (1998), pp. 51-74; B. Gainot, 'The Constitutionalization of General Freedom Under the Directory', in: M. Dorigny (ed.) The Abolitions of Slavery. from Léger Félicité Sonthonax to Victor Schoelcher (Oxford: Berghahn Books, 2003), pp. 180-196. Gainot assigns great significance to the law of 1798 as he judges it as less paternalistic and more egalitarian than Boissy d'Anglas' vision of subordinate assimilation. Cf. Dubois, A Colony of Citizens, pp. 298-300.

6 M.F. Spieler, 'The Legal Structure of Colonial Rule during the French Revolution', William and Mary Quarterly 66 (2009), pp. 365-408.

7 Popkin, You are all Free, pp. 384, 389.

8 Popkin, You are all Free, p. 328. 
Republic the decision by and large met with aversion, fear, and disenchantment. The application of a radical document meant for a civilization at the height of historical progress to what was widely regarded as a bunch of violent and infantile savages, incited many Dutch and American thinkers, journalists, and politicians to re-invoke and explicate boundaries of modern citizenship that had hitherto largely remained implicit. This process was accompanied by general feelings of disillusionment about the high and increasingly considered naively abstract ideals of the French Revolution in light of the island's disastrous course of events. The majority of Dutch Batavian revolutionaries too became convinced that they should not follow the astonishing and wavering French imperial policies of 1791-1794. Between 1798 and 1802, a broad and powerful public opinion in France began to distance itself from what was portrayed as the imperial chimeras of a reckless political faction.

After the overthrow of the Orangist regime in January 1795 and the instalment of the Batavian National Assembly in March 1796, the events in Saint-Domingue became a crucial reference point. The last quarter of the eighteenth century had been a time of both transformation and great uncertainty for the Dutch colonial empire. The colonial system based on trading companies came to an end. After decades of financial distress, the (second) West Indian Company (WIC) was finally liquidated in 1791. The much more profitable East Indian Company (voc) followed suit in $1796 .{ }^{9}$ As a result, governance of the West and East Indies came into the hands of the Dutch state, more specifically, into the hands of several state councils and committees.

After the Fourth Anglo-Dutch War (1780-84), the Dutch position in Asia, especially that of the voc, had been severely weakened, even though effectively not many of their colonial settlements were lost. The following decade and a half was essentially a period of contraction, both economically and demographically. The slave trade more or less collapsed. During the second half of the 1790s, the Dutch were even on the verge of losing their entire, once illustrious overseas trading empire. In 1795-96, a number of Indian and East Indian trading posts, Cape the Good Hope, as well as a number of small West Indian possessions on the Guiana coast were lost to the English. ${ }^{10}$ On the

9 The patent officially only terminated in 1799.

10 Namely Berbice, Demerara, Essequibo ('Dutch Guyana'). In 1803 the Dutch regained Cape the Good Hope but they lost it again to the English in 1806. 
island of Curaçao, partly inspired by the events in Saint-Domingue, a slave insurrection under the leadership of Tula from the west-Curaçaoan plantation Kenepa broke out in 1795 . But it was quickly suppressed and did not seem to have made any significant impact on debates in the Dutch Republic itself. ${ }^{11}$ In 1799-1800, Suriname and the (Benedenwindse) islands of the Leeward Antilles, Aruba, Bonaire, Curaça, fell into English hands, while the (Bovenwindse) islands of the Lesser Antilles, St. Maarten, Saba, and St. Eustasius, came under French rule. In short, although the situation was precarious due to continuous warfare, during the first few years of the Batavian Revolution the Republic still possessed Java and some smaller East Indian possessions, a number of trading posts in India, and in the West, Suriname and the Antilles.

The immediate causal importance of the debates in the Batavian National Assembly concerning the question whether a new Dutch constitution should apply to the Dutch colonies should therefore not be overstated. But it was also not merely a theoretical exercise. It is true, as economic historian Jan de Vries recently noted, that '[fo]r most merchants and investors the Atlantic world was understood as a zone of commercial activity first and of colonization and political power second'. Dutch Caribbean islands such as Curacao and St. Eustatius were nodal points in trade and commercial services, not plantation colonies. ${ }^{12}$ Yet, from the 168 os onward, a genuine plantation economy had been gradually established in Suriname and Dutch Guyana (Berbice, Essequebo, Demerary). ${ }^{13}$ Between the early 1700 and 1780 , the number of enslaved Africans in Surinam increased from 9,00o to about 6o,ooo. And although historians have traditionally considered the East Indies as being more important to the Dutch Republic's empire, between 1730 and 1780 the total value of

11 Oostindie and Klooster (eds.), Curaçao in the Age of Revolutions, 1795-180o.

12 Although the Dutch Atlantic has long been characterized as essentially a trading empire, the States General as well as other state institutions were on several levels entangled with the commercial companies, and at crucial moments made political and military interventions for strategical purposes. See, P. Brandon and K. Fatah-Black, 'For the Reputation and Respectability of the State': Trade, the imperial State, unfree Labor, and Empire in the Dutch Atlantic', in: J. Donoghue and E.P. Jennings (eds.) Building the Atlantic Empires: Unfree Labor and Imperial States in the Political Economy of Capitalism, ca. 150o-1914 (Leiden: Brill, 2015), pp. 84-108.

13 The growth of Dutch Guyana's plantation economy was to an important extent due to British West Indian and American entrepreneurs. G. Oostindie, 'British Capital, Industry and Perseverance' versus Dutch 'Old School'? The Dutch Atlantic and the Takeover of Berbice, Demerara and Essequibo, 1750-1815, BMGN - Low Countries Historical Review 127 (2012), pp. 28-55. 
commodity imports from the Atlantic had grown rapidly, and in the 1770 s even overtook the total value of imports coming from Asia. ${ }^{14}$

No anti-slavery movement emerged in the late eighteenth-century Dutch Republic. Yet the question of slavery and the slave trade were recurrent topics in literature, journals, and pamphlets..$^{15}$ During the late 1770 s and 1780 s, critical discussions of slavery had appeared in such journals as De koopman (The Merchant), De vaderlander (The Patriot), Bijdragen tot het menschelijk geluk (Contributions to Human Happiness), De leerzame praat-al (The Educational Chatter Box), and others. In 1792, the prominent Maatschappij tot nut van 't algemeen (Society for Public Welfare) organised an essay contest on the question: 'Is slave trade necessary under the pretext of interest according to the maxims of sound politics, and admissible according to divine and human law?' Prominent future revolutionaries such as Bernardus Bosch, Jan Konijnenburg, and Pieter Paulus, as well the jurist Hendrik Cras opposed slavery in both speech and writing, drawing extensively on British and French antislavery tracts. In literary texts, female authors such as Elisabeth Maria Post, Betje Wolff, and Petronella Moens raised the topic of slavery. The anti-slavery current was stronger than historians have sometimes made it out to be, but it lacked concrete action.

It did not take long for the Dutch planter class to start a counteroffensive against these abolitionist writings. A long pamphlet published in 1795 by an author who identified himself as a former planter from Demerary (Dutch Guinea), invoked the French 'philanthropic' emancipation decree in combination with an apocalyptic vision of Saint-Domingue's destroyed plantations and murdered planters to dismiss any suggestion that the black slaves were to be liberated. 'Negroes must be considered human beings', the author admitted, but 'without education, without religion, without morality'. He identified Grégoire and Condorcet as the principal authors behind French abolitionism. But allowing slaves on the Dutch colonies 'unbridled liberty' would be a 'deadly

14 The annual average revenue from the West-Indies increased from 5,600 (in thousands of guilders) for the period $1730-1739$ to 22,400 for the period $177^{-1}-179$, whereas the annual average revenue from Asia for the period 1730-1739 was 16,705 and 19,951 for the period 1770-1779. J. de Vries, 'The Dutch Atlantic Economies', in: P.A. Coclanis (ed.), The Atlantic Economy during the Seventeenth and Eighteenth Centuries: Organization, Operation, Practise and Personnel (Columbia, S.C.: University of South Carolina Press, 2005), pp. 1-29, at p. 19.

15 See Paasman, Reinhart: Nederlandse literatuur en slavernij ten tijde van de Verlichting; G.J. Schutte, 'Zedelijke verplichting en gezonde staatkunde. Denken en doen rondom de slavernij in Nederland en koloniën eind $18^{\mathrm{e}}$ eeuw', in: Documentatieblad werkgroep $18^{\mathrm{e}}$ eeuw 41-42 (1979), pp. 101-115; Sens, 'Mensaap, heiden, slaaf. 
gift'. Why should the consequences of the emancipation of black slaves be feared? The author replied that the 'answer to that question can be found in the reports on St. Domingo of the last four years'.16 According to these planter class representatives the liberation of black slaves would be the death knell to the already weakened Dutch empire. Despite such rhetoric, however, many Batavian revolutionaries at the time were overall optimistic that much of the Dutch empire could and would be restored. During the Batavian Revolution their engagement with the Dutch empire was more about envisioning colonial reform than actual governance or implementing new policies. ${ }^{17}$

After the regime change in January 1795 and the rather delayed formation of a National Assembly the following year, the Batavian National Assembly from March 1796 onward started to work on a new constitution that was to serve as the foundation for the new Batavian Republic. In early 1796, a 'Committee for Affairs Relating to East Indian Trade and Possessions' was established. It effectively replaced the former Board of Directors of the East India Company. By December, in a draft for the section on the East India colonies, the leading member of the Committee Samuel Wiselius together with Bogilaus von Liebeherr came up with a remarkable proposal for an egalitarian republican empire. It had much in common with the imperial visions of the Amis des Noirs. ${ }^{18}$ Weighing up the sweet benefits of empire and the revolutionary era's

16 [Anonymous], Vrymoedige gedachten, van een (geweest zynde) Demerariaansch planter, over twee brieven geschreeven onder den naam van Zelidor aan Eliante; behelzende een beschryving van den slavenhandel, en onderzoek, of men recht heeft om vrye menschen tot slaaven te maaken, en of de negers in slaverny moeten blyven (Amsterdam: Gaspart Heintzen, 1795), pp. 11, 66-74. The pamphlet was a reaction to Jean-Henri des Villates, Brieven over Wijsgeerige en andere onderwerpen (The Hague: J.C. Leeuwestijn, 1795).

17 Cf. Gert Oostindie's remark: 'We should not assume that contemporaries were already anticipating this overall decline of the Dutch Atlantic. During the Age of Revolutions as well as at its conclusion, policy makers voiced optimism in spite of their painful awareness of Dutch decline, or at least the conviction that the Caribbean colonies could play a vital role in the Netherlands regaining the status of a serious world player'. G. Oostindie, 'Dutch Atlantic Decline during the "Age of Revolutions"', in: G. Oostindie and J.V. Roitman (eds.) Dutch Atlantic Connection. Linking Empires, Bridging Borders (Leiden: Brill, 2014), pp. 309-335; Schutte, De Nederlandse patriotten en de koloniën, pp. 214-215.

18 On the Dutch consitution, the colonies and the issue of slavery in the age of revolutions, see Lubbertus Les, Van Indië onder de Compagnie tot Indië onder de staat: De koloniale titel in de Staatsregeling van 1798 (Rotterdam, 1947); Schutte, De Nederlandse Patriotten; Schutte, 'Zedelijke verplichting ene gezonde staatkunde'; A.H. Huussen Jr., 'De Staatsregeling van 1798 en het slavernijvraagstuk', in: O. Moorman van Kappen and C. Koppens (eds.) De Staatsregeling voor het Bataafsche volk van 1798: Opstellen opgedragen aan de nagedachtenis van Dr. Mr. L. De Gou (Nijmegen: Gerard Noodt Instituut, 2001), pp. 213-232. In the same edited volume: B. Sirks, 'De Constitutie van 1798 en de koloniën', pp. 197-212. 
philosophical principles, Wiselius and Von Liebeherr stated in their draft that 'in so far as they fall under the authority of the Dutch', the colonies 'must always be considered as inseparable parts of the united and indivisible Republic'. As the second basic principle they proposed that the colonies' inhabitants ought to 'share in, and enjoy all those political and civil rights and privileges to which the inhabitants of the Republic according to the new constitution are entitled. ${ }^{19}$ But they immediately added that these rights could only be granted to the colonies' inhabitants if the 'special' circumstances would allow such a bold move.

The Committee was subsequently asked to devise a general draft for the entire empire in the both the East and West Indies. But no agreement on the status of the colonies could yet be reached. The debate was continued in the Spring of 1797. On February 3, the National Assembly established two new committees on colonial affairs. The first, chaired by Jacob Uytenhage de Mist, was assigned the task of giving advice on the relationship between the mother country and Surinam, Berbice, and the West-Indian and African oversee possessions. The other, chaired by Hendrik Jacob Floh, was assigned the task of giving a more general advice on how the relationship with the colonies ought to be written into the constitution. This 'Floh report' was presented to the National Assembly on April 11 and discussed that same month. Like Wiselius and Von Liebeherr, the Floh report defined the colonies as 'unalienable possessions of the state' in which the colonists were fully entitled to their 'natural and civic rights'. In articulating the nature and constitutional foundations of the Batavian republican empire, the report was preoccupied with two 'extremes': the French and British empires. Britain, on the one hand, had lost sight of the 'initial contract' with its American colonists. Instead of establishing a relationship of equality, the American colonists were made 'subservient' to the British who had turned the colonists into a 'pile of slaves'. The consequences were well known. The French, on the other hand, had 'lapsed into the opposite extreme' by proclaiming principles of universal equality in their colonies. ${ }^{20}$ Similar assessments of these 'two pernicious extremes' and 'powerful and fatal experiments' were made outside the confines of parliament. Members of the The Hague based Societeit voor eenheid en orde (Society of Unity and Order) reported in 1797:

19 'Bijlagen' in: Les, Van Indië onder de Compagnie tot Indië onder de staat, p. 115. This draft chapter applied to the Asiatic possessions and Cape the Good Hope, but the following 'title [...] of the colonies' made the same point. 
The British domination of American colonies, in itself unjust and unlawful, has grabbed from Great Britain the sweet benefits that contributed to the domestic prosperity and commercial interests of that very empire. The consequences of the, by itself, philosophical principles of the French, prematurely applied in their West-Indian possessions, have been both for the colonists and the French Republic most harmful and dreadful - and we are fortunate to take warning from these examples and their inescapable consequences, steer clear of these perilous rocks, and settle on a safe middle course. ${ }^{21}$

Given these examples and the precarious state of their colonial empire, the majority of Batavian revolutionaries were keen on proceeding carefully. The leading republican-democratic representative Pieter Vreede, on the other hand, was astonished that the section on the colonies as proposed by the Floh Committee made no mention of slavery and the slave trade whatsoever. Although he was aware of the 'unfortunate example of our French brothers', he urged his fellow representatives not to establish a constitution that 'violates the rights of humanity'. ${ }^{22}$ Only a constitution that would explicitly speak out against the slave trade and slavery, Vreede argued, would be worthy of their revolution. During the subsequent debate over the Floh report and Vreede's intervention, the prominent moderate representative Rutger-Jan Schimmelpenninck warned his colleagues that the name of St. Domingo alone should make you think twice'. It represented nothing less than '[ $t$ ]he very voice of humanity', and this voice 'calls out to you to be cautious.' ${ }^{23}$ The Floh report itself had not minced its words either. Saint-Domingue had fallen into 'the most woeful chaos and miserable savagery'. As Batavian revolutionaries were envisioning the future of their own colonial empire, Saint-Domingue was on everyone's mind.

As in the United States, in the Batavian Republic it would be repeated over and over again that the French - particularly the 'philanthropists' and politicians associated with the Société des Amis des Noirs - had made a disastrous

21 Rapport van de burgers Goldberg, Verbeek en Scheffer, uitgebragt in eene vergadering van de Societeit voor eenheid en orde in Den Haag, over het ontwerp van constitutie, zo als het zelve door de Nationaale Vergadering, representeerende het volk van Nederland, aan het Bataaffsche volk ter goed of afkeuring is voorgedragen (Den Haag: I. van Cleef, 1797), p. 56. The report is discussed in: C. Rogge, Geschiedenis der Staatsregeling, voor het Bataafsche volk (Amsterdam: J. Allart, 1799), pp. 392-394.

22 Dagverhaal 5, no. 493, 28 april, 1797 (session April 22), p. 727.

23 Dagverhaal 5, no. 491, 27 april, 1797 (session April 22), p. 716; Dagverhaal 5, no. 493, 28 april, 1797 (session April 22), p. 729 . 
mistake. It seemed obvious that there was a direct causal relationship between the utopian extension of French 'philosophical' principles and the disastrous course of events in Saint-Domingue. The Floh report stated that

[ $\mathrm{t}$ ] he French nation at the dawn of her revolution, heated by the mesmerizing and conjuring notions of universal freedom and equality of rights, by their mistaken and premature application [...] and by proclaiming these general philosophical principles in her distant and extended colonies, quickly occasioned the destruction of all social order. ${ }^{24}$

The tragic case of Saint-Domingue was repeatedly evoked as a spectre, as proof of the danger of immediate emancipation. Although Jacob Hahn, a prominent speaker in the National Assembly, supported the liberation of black slaves, he also opposed 'rash and reckless' decisions. Schimmelpenninck agreed and called upon his colleagues to realize that in Europe only over a timespan of 'many, many years' the 'system of freedom' had gradually taken hold. He did not doubt that in the long run the 'system of true popular liberty' should be 'propagated and spread' around the world. ${ }^{25}$ But Schimmelpenninck and his moderate colleagues employed the language of the inequality of civilization and enlightenment in order to park the question of immediate emancipation. In the end, the Floh committee was instructed to produce a new report on the question if and to what extent the new constitution should mention the abolition of the slave trade. The question of the abolition of slavery as such, let alone the question of equal citizenship for freed slaves, were quietly left out.

The follow-up report by the Floh committee was debated exactly one month later, on May 22. Saint-Domingue was again the key reference. Floh at one point even confessed that the committee members gladly would have liked 'to cast a veil over the horrors' of Saint-Domingue, since the 'disasters' had been covered by the press in such a way that everyone should by then have been 'sufficiently instructed and warned. ${ }^{26}$ Saint-Domingue's surrender to lawlessness and the supposed ungovernability of black slaves signified a 'return to its former state of wilderness', the report noted. ${ }^{27}$ Such characterizations of the civil war in Saint-Domingue were not a slip of the tongue. They helped to establish an intricate connection between the exceptional atrocities for which

\footnotetext{
24 Dagverhaal 5, no. 491, April 27, 1797 (session April 22), p. 716.

25 Dagverhaal 5, no. 493, April 28, 1797 (session April 22), p. 729.

26 Dagverhaal 5, no. 491, 27 april, 1797 (session April 22), p. 716; Dagverhaal 6, no. 547, June 1, 1797 (session May 22), pp. 3-8, at p. 7 .

27 Dagverhaal 6, no. 547, June 1, 1797 (session May 22), p. 8.
} 
Saint-Domingue was infamous and the alleged mentally and morally savage or 'uncivilized' condition of the slaves. The 'dangerous and misleading' French course of action to abolish slavery immediately was a key argument to omit both the slave trade or slavery in the constitution. Instead, in the debate that followed, the strategy and language of 'civilizing' slaves gradually through education (instead of liberating them immediately) was omnipresent. Two representatives emphasized the need to first educate the 'Negroes' so as to 'impart civilization' to them and make them 'susceptible' to liberty. ${ }^{28}$

The radical democratic-republican Pieter Vreede, in what was perhaps the most powerful and passionate antislavery speech in the brief history of the Batavian Republic, was less dismissive of French 'experiments' in universalism. He considered the French course of action merely an 'ill-advised' response to what he nonetheless considered a 'noble desire of the soul'. The 'piteous imprudence' of the French, he suggested, should rather 'serve as a manual' for the question how to approach the issue of the liberation of black slaves. ${ }^{29}$ Still, Vreede was no supporter of immediate emancipation either. But in his view the constitution at the very least ought to mention the intention of abolishing slavery. If the National Assembly would not seize this opportunity, 'What else is this than constitutionally legitimating these barbaric crimes?' Some of Vreede's fellow democratic-republican representatives supported him. But the great majority of the Batavian representatives in the end decided that the constitution should remain completely silent about the topic.

The first draft constitution offered to the Dutch people was rejected by referendum on September 13, 1797. In late December 1797 the National Assembly returned to Wiselius and Von Liebeherr for advice on the status of the colonies within the constitution. In the discourse préliminaire to a new draft, the authors reaffirmed as 'foundational principle [...] that equality, the foundation of civic freedom, allowing no distinction in rights between members of the same citizen state ('Burgerstaat'); the rights as well as the duties of Batavian citizens in Asia, Africa, and America, must be like those that actually apply within Europe. ${ }^{30}$ Having observed the experience of France, they added however that the implementation of equal citizenship throughout the empire was dependent on the 'natural and moral circumstances' of the parts of the empire in question. With an eye to the French colonial experiment, they stressed that

28 Dagverhaal 6, no. 548, June 2, 1797 (session May 22), p. 15; Dagverhaal 5, no. 493, April 28, 1797 (session April 22), pp. 731-733.

29 Dagverhaal 6, no. 548, June 2, 1797 (session May 22), p. 11.

30 S. Wiselius et al,. Ontwerp van vertoog, om te worden geplaatst in het voorafgaande vertoog (discours préliminaire) voor het ontwerp van constitutie, December 18, 1797. As cited in: 'Bijlagen', in: Les, Van Indië onder de Compagnie tot Indië onder de staat, p. 126. 
'attributing' the rights of man to black slaves did not automatically imply 'effectuating' them as citizenship rights. ${ }^{31}$

Most Batavian revolutionaries simply assessed the state of the Dutch empire as too fragile to make any major decisions on the gradual or immediate abolition of slavery. Economic interests no doubt played a part too. But the relatively conservative outlook can also be explained by the frightening example posed by the French colony of Saint-Domingue. Almost without exception, it proved to Batavian revolutionaries that equal citizenship requires enlightenment and civilization. Tellingly, even the Batavian constitution of May 4, 1798, a product drawn up by democratic-republican radicals, merely declared the state owner of the 'foreign possessions and colonies'. Colonial profits were destined for the treasury. Any further explicit discussion of the relationship between the colonial empire and the motherland was 'postponed', including the question of equal citizenship rights within the empire. Not a word on the slave trade, slavery or abolition. ${ }^{32}$

For most Batavian revolutionaries debating the future of their colonial empire and the civic status of its inhabitants the baseline was what may be called 'enlightened' citizenship. This begs the question what 'enlightened' citizenship entailed and in what broader social and historical outlook it appeared. An evocative perspective on late eighteenth-century enlightened citizenship that relates this picture of the 'modern' citizen directly to the 'Saint-Dominguan slave' is offered by the Dutch publicist and medical doctor G. Schutte in an 1797 article in Nieuwe Bijdragen tot het menschelijkgeluk (New Contributions to Human Happiness). His essay titled Verhandeling over den tegenwoordigen volks-geest, in zoo verr' dezelve door de wijsbegeerte gewijzigd is (Treatise on the Current State of the People's Mind, in so far as it has been modified by Philosophy) bears a striking resemblance to Condorcet's outline in his famous Esquisse d'un tableau historique des progrès de l'esprit humain. The foundation of Schutte's Condorcetian account is man's natural 'inclination' for 'self-enquiry'. ${ }^{33}$ Like Condorcet, Schutte attached great importance to the rise of 'experimental

31 Wiselius et al., Ontwerp van vertoog, p. 126.

32 Les, Van Indië onder de Compagnie tot Indië onder de staat, pp. 40-61; Schutte, De Nederlandse patriotten en de koloniën, pp. 141-150. Les argues that the silence in the constitution of May 1798 on slavery can be explained by the influence of the more conservative Committee on East-Indian Trade and Possessions. Schutte adds that radical abolitionists like Vreede were a minority, even among the democratic republicans. Cf. Huussen jr., 'De staatsregeling van 1798 en het slavernijvraagstuk'.

33 G. Schutte, 'Verhandeling over den tegenwoordigen volks-geest, in zoo verr' dezelve door de wijsbegeerte gewijzigd is', Nieuwe bijdragen tot het menschelijk geluk 1 (1797), pp. 127-151, at p. 127 . 
philosophy', and the ways in which the insights generated by this new philosophy impacted the 'direction of the human mind' ${ }^{34}$ Certainties acquired in mathematics had penetrated 'the moral world'; modern 'ethics' taught, among other things, that 'we are at liberty to enjoy the delights made available by industry and industriousness'. Furthermore, this enlightened morality 'imposes societal life as a duty' ${ }^{35}$ Man thus 'gradually casts aside the crudeness of morals as well as his savage nature, of which our forefathers - whatever one might say of the good old days - cannot be completely exempted'. ${ }^{36}$ In Schutte's view citizens in advanced societies are characterized by continuous 'exercise of intellectual power'; by the 'love of reading' that 'penetrate into all classes'; by the increased visit to 'theatre, that great place for people's education'; by the growing number of 'learned societies' and 'the exchange of views about all kinds of subjects.' ${ }^{37}$ Schutte, in short, provided a picture of the social and moral world of the enlightened, sociable citizen. ${ }^{38}$

The modern citizen was in his view assigned the important task to spread the advantages and delights of societal life: "The only thing the frail mortals can accomplish is cultivating the arts and sciences, furnishing them to the taste of the people, gradually undermining the walls of prejudice' - all of this should be pursued to gradually reach man's 'perfection'. But, Schutte warned, in this endeavour one should also 'follow nature'. Nature 'makes no leaps, she develops gradually':39

He, who suddenly lets brighter rays of truth shine into the eye of the weak man, makes his vision fuzzy by the glaring light. He who recklessly hands over the rights of man to the negroes of St. Domingo causes the destruction of the colony, which will become the victim of his carelessness. ${ }^{40}$

Schutte's juxtaposition of, first, the moral and societal landscape of advanced citizenship and then, at the very end of his essay, the 'negroes' of SaintDomingue was no coincidence. His articulation of enlightened citizenship and its limits - was part and parcel of the Batavian citizenship discourse. The Batavian model of citizenship diverged from those of the 'reckless' French.

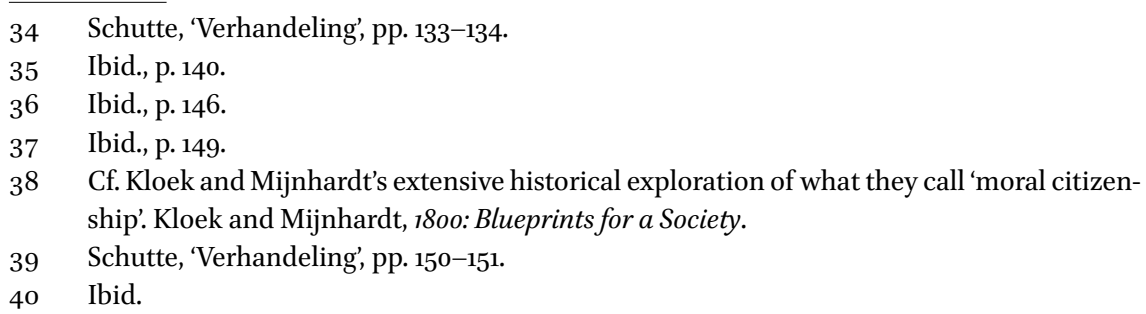


Such schemes of natural equality made compatible with civilizational inequality prevailed in the 1790s. The Dutch professor of natural law and law of nations at Groningen University, Frederick Adolph van der Marck, for example, insisted in his 1798 Schets over de rechten van den mensch (Sketch on the Rights of Man) that 'after all, so-called slaves are like us rational beings, inhabitants of this universe, and God's creatures'. In terms of 'unalienable rights', he maintained, they are 'our equals'. The relevant distinction for Van der Marck was education: '[S]laves, due to lack of good education, are not yet susceptible to true freedom, and in that respect are to be considered children, unable to make use of their reason, and whom one should not hand over a knife to harm themselves or others'. ${ }^{41}$ Earlier, on the floor of the Batavian National Assembly, this metaphor had been employed by representative Van Hoorn who claimed that the rights of man had been given to the slaves of Saint-Domingue prematurely which in his eyes demonstrated that 'everywhere freedom without enlightenment is sharpened steel in childhood's hands.' ${ }^{42}$

At the turn of the nineteenth century, the Dutch reading public could read a fairly representative summary of the series of interpretations of the events on Saint-Domingue we have discussed so far in Konijnenburg's multivolume Tafereelen van de staatsomwenteling in Frankrijk (Scenes of the Revolution in France). To Konijnenburg's mind it was clear that declaring 'people of colour free men' and 'citizens of the state' had been a 'righteous deed' that corresponded to 'the principles that were adopted in all candour'. 43 He decried the white planters for whom the 'last remaining drop of African blood' was enough to deny coloured people any 'political influence'. In his view the enthusiasm about granting citizenship to free people of colour could not remain separated from the question of slave trade and the institution of slavery in general. As Konijnenburg saw it, the colonial question on the most general level was indeed 'whether the declared rights of man were to apply in the colonies too'. He was convinced that the slave trade and the suppression of black slaves were 'direct violations of the rights of man'. The events on Saint-Domingue had expanded the revolutionary agenda, he fully recognized the logic of the rights of man.

But in describing the unfolding civil war in Saint-Domingue Konijnenburg made allusions to the island's return to a 'state of nature'; the island, he wrote,

41 F.A. van der Marck, Schets over de rechten van den mensch, het algemeen kerken- staats- en volkerenrecht, ten dienste der burgery ontworpen (Sketch on the Rights of Man, General Canon Law, Constitutional Law, and Law of Nations, drafted for the Benefit of the Citizenry; Groningen: J. Bolt, 1798) (emphasis in original), pp. 186-191.

43 Konijnenburg, Tafereelen van de staatsomwenteling in Frankrijk, vol. 6, p. 107. 
was 'recreated into wilderness'. The black insurgent was portrayed as a savage who 'by the number of thousands desecrate everything in their path with their relentless rage', and trespassing all moral boundaries, as 'neither the youth, nor the elderly, neither child, nor pregnant women were spared.' ${ }^{44}$ The unfolding civil war's exceptional 'atrocities', Konijnenburg asserted, had something to do with the distinct background of the black slave. He asked his readers to 'imagine the African's fiery character, his deep sense of insult, his multiplied number, his heated thirst for revenge and freedom'. This 'image' of an African barbarian, Konijnenburg supposed, 'in itself is enough to shrink back of any further vision that would bring to mind horrors by which the human soul would grievously shrivel: 45

Batavian revolutionaries in the National Assembly, opinion makers such as Schutte, the law professor Van der Marck, and Konijnenburg: they all recognized the pressure of the 'logic' of the equal rights of man. But by invoking the 'atrocities' of Saint-Domingue, the slaves' stage of civilization, and the French mistaken application of universalist principles, they distanced themselves from such universalist models of imperial citizenship. It was an Atlantic Thermidorian moment in which the idea of a shared revolutionary project of citizen emancipation started to crumble.

Between 1794 and 1800 in the United States, too, the French citizenship model that now encompassed freed slaves was increasingly considered as alarmingly dangerous, a 'Jacobin' solution alien to the American state of affairs. SaintDomingue became an important reference point in St. George Tucker's A Dissertation on Slavery: With a Proposal for the Gradual Abolition of It in the State of Virginia published in 1796. Tucker was a prominent Virginia lawyer, law professor at the College of William and Mary, and judge of the Virginia General Court and later the Supreme Court of Appeals. His pamphlet is often invoked as one of the most elaborate and widely known pleas for gradual emancipation at the time, although the legislature of the state of Virginia did not approve it. ${ }^{46}$ Read in a transatlantic context, it can be interpreted as an American variant of a broader disenchantment with 'French' emancipation policies.

44 Konijnenburg, Tafereelen van de staatsomwenteling in Frankrijk, vol. 10 (180o), pp. 85-93.

45 Konijnenburg, Tafereelen van de staatsomwenteling in Frankrijk, vol. 15 (1802), p. 121.

46 Guyatt, Bind us Apart, 17-21; Sinha, The Slave's Cause, 90-91. 
Tucker wished to see slavery abolished, but he was not in favour of fullblown civic emancipation. In his proposal, he recalled ' $[\mathrm{t}]$ he recent history of the French West Indies' which 'exhibits a melancholy picture of the probable consequences of a general, and momentary emancipation'. ${ }^{47}$ He went on to explain that 'European migrants, from whatever country they arrive, have been accustomed to the restraint of laws, and to respect the government'. Black slaves however, 'accustomed to be ruled with a rod of iron', will not 'easily submit to milder restraints'. Immediate emancipation would turn them into 'hordes of vagabonds, robbers, and murderers'. This should come as no surprise Tucker said, for ' $[w]$ ithout the aids of an enlightened policy, morality, or religion, what else could be expected from their still savage state, and debased condition?'48 Consequently, although Tucker supported the abolition of slavery, he also argued that 'emancipation does not confer the rights of citizenship'49 He was fully aware of the more radical position of those who argued " $\mathrm{t}]$ hat there must be no distinction of rights; that the descendants of Africans, as men have an equal claim to all the civil rights, as the descendants of Europeans; and upon being delivered from the yoke of bondage have a right to be admitted to all the privileges of a citizen'. Tucker, however, argued that it is up to the civic community to determine who is eligible to become a full member. He thus proposed a model that comprised a first and second-class type of citizenship, for '[w]e must [...] endeavour to find some middle course'. One day, black men could perhaps be conferred full citizenship status. But '[n]ature, time, and sound policy must co-operate with each other to produce such a change. ${ }^{50}$ In a letter to Jeremy Belknap, an influential Boston congregational minister, Tucker mentioned the time span of no less than a century for complete civic emancipation to arrive and 'to see the Foundation of universal freedom in the United States.' ${ }^{51}$ The boundaries of the 'universal' could be stretched, indeed.

47 St. George Tucker, A Dissertation on Slavery: With a Proposal for the Gradual Abolition of It in the State of Virginia (Philadelphia, PA: M. Carey, 1796), pp. 79-80. The gradualist line of reasoning that underpinned Tucker's moderate antislavery position was widely praised, among others by such influential officials as justice and future Massachusetts governor of state James Sullivan. Letter from James Sullivan to Jeremy Belknap, July 30, 1795, with a letter from St. George Tucker to Jeremy Belknap, 10 February 1796. Tucker submitted copies of his pamphlet to the houses of the Virginia legislature, and to Thomas Jefferson.

48 Tucker, $A$ Dissertation on Slavery, p. 86.

49 Ibid., p. 75 .

50 Tucker, A Dissertation on Slavery, p. 90 (emphasis in original).

$5^{1} \quad$ Letter from St. George Tucker to Jeremy Belknap, November 27, 1795. http://www.encyclopediavirginia.org/Letter_from_St_George_Tucker_to_Jeremy_Belknap_November_27_1795 (date of access: June 26, 2013). 
Tucker's dismissive evaluation of the French emancipation decree was part of a more widespread rejection of French universalism in which SaintDomingue figured prominently.52 Such views the American reading public would come across in Bryan Edwards' account of the Haitian Revolution. Edward's 'Narrative of the Calamities which have desolated the Country ever since the Year 1789' appeared in his The History, Civil and Commercial, of the British Colonies in the West Indies. This multivolume history would become immensely influential in the early American republic, as historian Edward Rugemer has recently demonstrated. ${ }^{53}$ Edwards, a British colonial politician in Jamaica, plantation holder, and historian - 'the pre-eminent statesmanintellectual' of the British West Indies according to David Brion Davis -witnessed the slave insurrection when he came to the aid of French planters in September $1791 .{ }^{54}$ His account related of insurgents 'spreading death and desolation', ${ }^{55}$ To enhance the dramatic effect, he contrasted the once 'magnificent and romantick landscapes' with 'the miseries of war, and the horrors of pestilence; to scenes of anarchy, desolation, and carnage. ${ }^{56}$ Like so many of such characterizations, Edwards emphasized the unique nature of the civil war in Saint-Domingue. It was of a different kind than the anarchy that would come about as a consequence of any other 'regular' civil war. The savage

52 Cotlar, Tom Paine's America; Newman, 'American Political Culture and the French and Haitian Revolutions'.

53 B. Edwards, An Historical Survey of the French Colony in the Island of St. Domingo comprehending a Short Account of its Ancient Government, Political State, Population, Productions, and Exports; A Narrative of the Calamities which have desolated the Country ever since the Year 1789, with some Reflections on their Causes and Probable Consequences, and a Detail of the Military Transactions of the British Army in that Island to the End of 1794 (London: J. Stockdale, 1797). Edward's account of Saint-Domingue was first published as a single volume. It appeared as the fourth volume of his The History, Civil and Commercial, of the British Colonies in the West Indies (London: Crosby, 1798). This classic work first appeared in two volumes in 1793. It saw as many as five editions and was expanded to five volumes, and was translated into French and Dutch (early 180os), as well as German, Portuguese and Italian. It came out in Philadelphia in 1806. Other American editions appeared in 1805 and 1810 (by three different printers). E. Rugemer, The Problem of Emancipation: The Caribbean Roots of the American Civil War (Baton Rouge, LA: Louisiana State University Press, 2008), pp. 8, 52-53. On Edwards, see O.M. Blouet, 'Bryan Edwards and the Haitian Revolution', in: Geggus (ed.) The Impact of the Haitian Revolution in the Atlantic World, pp. 44-57; R.B. Sheridan, 'Edwards, Bryan (1743-180o)', in: Oxford Dictionary of National Biography (Oxford: Oxford University Press, 2004); online ed. Jan 2008 [http://www.oxforddnb.com/ view/article/8531, date of access: 17 April 2013].

54 Davis, The Problem of Slavery, p. 188.

55 Edwards, An Historical Survey, iii.

$5^{6}$ Edwards, An Historical Survey, iii, xviii-xix. 
character of the insurgents accounted for this uniqueness, readers learned from Edward's widely read narrative:

Such a picture of human misery; - such a scene of woe, presents itself, as no other country, no former age has exhibited. Upwards of one hundred thousand savage people, habituated to the barbarities of Africa, avail themselves of the silence and obscurity of the night, and fall on the peaceful and unsuspicious planters, like so many famished tiger thirsting from human blood. ${ }^{57}$

The insurrection of Saint-Dominguan slaves was, thus, cast in the now familiar terms of anarchy, savagery, and African barbarism.

In his explanation of how this horrible situation had come about, Edwards charged that ' $[p]$ roceeding on abstract reasoning, rather than on the actual condition of human nature', the French 'distinguished not between civilized and uncivilized life..$^{58} \mathrm{He}$ specifically singled out Grégoire's letter to the SaintDominguan free people of colour. 'What effect this distinguished piece of oratory may have had on the rugged and unenlightened minds of savage people', he venomously wrote, 'I pretend not to ascertain.' ${ }^{59}$ Like many French planters, Edwards primarily targeted the Société des Amis des Noirs for inciting the rebellion:

$[T]$ he rebellion of the negroes in St. Domingo, and the insurrection of the mulattoes $[\ldots]$ had one and the same origin. It was not the strong and irresistible impulse of human nature, groaning under oppression, that excited either of those classes to plunge their daggers into the bosoms of unoffending women and helpless infants. They were driven into those excesses - reluctantly driven - by the vile machinations of men calling themselves philosophers. ${ }^{60}$

Edwards' assessment of the 'excesses' of French philosophers was unmistakably dismissive, but he was not overall unsympathetic to either the ideals of the French Revolution or the North American struggle for independence. 'It is to be lamented', Edwards noted, 'that a principle so plausible in appearance, should, in its application to this case, be visionary and impracticable'. He

6o Ibid., $\mathrm{xx}$-xxi. 
deemed the acceptance of the proclamation of the 'celebrated declaration of rights [...] a revolution unparalleled in history', but hastened to add, that '[h]appy had it been for the general interest of the human race, if, when the French had gone thus far, they had proceeded no farther!' ${ }^{61}$

Accordingly, the immediate emancipation of black slaves into citizens was rendered another foolish instance of Jacobin utopianism that could but end in bloodshed. As Edwards dramatically put it, the French experiment with universalism was 'the homage of enlightened reason on the altar of humanity'. 62 These sentiments towards French universalism as articulated by Edwards dealt another heavy blow to what had been a short-lived transnational moment of converging citizenship ideals.

This is not to say that Edward's was the only discourse around at the time. A considerable number of American merchants from the northern and middle states, and those sympathetic to their interests, viewed Saint-Domingue differently. Many of them opposed slavery and were involved in the booming trade with the island of Saint-Domingue. ${ }^{63}$ In the second half of the 1790 s, with growing Franco-American tensions, the northern Federalist political and merchant class was not opposed to the diminishing influence - or even removal of France as one of the major European powers in the Caribbean. Around the turn of the century a considerate number of them welcomed doing business with the new black leader Toussaint Louverture. ${ }^{64}$ But the ideological aspect of this attitude toward business opportunities with the new Saint-Domingue authorities was weak at best. Instead, what both southern plantation owners and northern merchants in the end came to share was their disenchantment with revolutionary France.

In 1798 , the political climate was such that an American Federalist candidate from New Jersey reckoned it a prudent political strategy to accuse his Democratic opponent of being 'a Jacobin, Frenchman, and a leveler of all order and distinction', who 'intended to advocate the immediate emancipation of all

\footnotetext{
61 Edwards, An Historical Survey, p. 17.

62 Edwards, An Historical Survey, p. 82.

63 J.A. Dun, "'What Avenues of Commerce, Will You, Americans, Not Explore!": Commercial Philadelphia's Vantage onto the Early Haitian Revolution', The William and Mary Quarterly 62 (2005), pp. 473-504.

64 L.L. Montague, Haiti and the United States 1714-1938 (Durham, N.C.: Duke University Press, 1940), pp. 34-46; M. Zuckerman, 'The Power of Blackness: Thomas Jefferson and the Revolution in St. Domingue', in: idem, Almost chosen People. Oblique Biographies in the American Grain (Berkeley, CA: University of California Press, 1993), pp. 175-219, esp. pp. 186-195.
} 
the Negroes'.65 It was in this climate that a 'lay preacher' from Maryland in the Federal Gazette \& Baltimore Daily Advertiser particularly targeted Condorcet as the bogeyman of 'this dangerous, deistical and Utopian school'. The French philosophe was 'eager that the blacks of the isles should be emancipated' but '[p]hilosophy disdains the tardy step of time', the author retorted, implying that black slaves were not ready for immediate emancipation: 'Instead of viewing man as he is, they are perpetually devising plans for man as he should be', the lay preacher continued. 'They wish to fashion nature and society in their whimsical mould, instead of regulating that mould, according to the proportions of society and nature'. Instructed by philosophy that 'all men are equal', the Frenchman was 'careless how many houses of the whites were consumed'. In sum, in the eyes of such commentators (echoing Edmund Burke's rhetoric) the radical French emancipation project was a dangerous piece of 'abstract, inapplicable, metaphysico politics' ${ }^{\prime 6}$

\section{The French Colonial Thermidor}

The French Thermidorian regime of 1794-1795 kept the emancipation decree passed by the Montagnard-dominated National Convention intact. But the French colonial empire remained governed by a civilizational hierarchy. The speech accompanying the presentation of the 'Report and draft of constitutional articles related to the colonies' delivered by François-Antoine Boissy d'Anglas, one of the principal architects of the Thermidorian Constitution in July 1795 , can be seen as an ideological restatement of a qualified egalitarian French republican empire. ${ }^{67}$ Touching on a variety of issues, Boissy d'Anglas' speech was beset with tensions, if not outright inconsistencies. Perhaps more

65 The Centinel of Freedom (Newark, New Jersey), October 30, 1798. Also cited in Cotlar, Tom Paine's America, p. 65. Cotlar cites the Independent Chronicle (Boston, Massachusetts), November 5, 1798, in which the article was reprinted.

66 Federal Gazette \& Baltimore Daily Advertiser (Baltimore, Maryland), July 25, 1798.

67 Jeremy Popkin has recently argued that the Thermidorian Convention's decision not to repeal the Montagnard emancipation act of 1794 (unlike much other social legislation passed prior to the fall of Robespierre) was, although partly pragmatic, significant in that they embraced racial emancipation and an 'egalitarian republican empire'. Popkin admits that even the most outspoken supporters of emancipation in the metropole, such as Defermon, qualified their proposals for equal citizenship by suggesting that blacks were not ready for freedom and that regimes of forced labour were therefore necessary, and colonial representative institutions should be prohibited. Miranda Spieler emphasizes the limited significance of the 1795 decrees on the colonies and the ambiguities surrounding the legal status of the imperial realm. J. Popkin, 'Thermidor, Slavery, and the "Affaire des 
than any other text, it represents the spirit of the modern republican mind committed to the principles as set out in the Declaration of the Rights of Man and Citizen, while wholeheartedly defending a colonial empire based on a civilizational hierarchy. Since Boissy d'Anglas was addressing multiple interest groups and audiences, this might account for his contradictory statements. Without a doubt, the post-Terror political climate of moderation and reconciliation played its part too. Above all his speech was an expression of the complicated way French republicans tried to reconcile their commitment to revolutionary principles with a model of second class colonial citizenship within a republican empire. ${ }^{68}$ The complete abandonment of the ideal of equal citizenship throughout the empire for all inhabitants was only pushed through in the period 1798-1802.

First, Boissy d'Anglas accepted the revolutionary logic of universal principles: 'The abolition of slavery was solemnly decreed [...] and you would not wish to change it', Boissy d'Anglas impressed upon his audience. '[I]t was a consequence of your principles, one of the results of your revolution, and you could not fail to proclaim them pompously' ${ }^{69} \mathrm{He}$ went on to evince his faith in the benign effects of a constitution, 'the serpent of bronze that cures all injuries'. For the constitution to become 'eternal', it was necessary 'that its benefits make themselves felt in two hemispheres':

The revolution that you underwent was not solely reserved for Europe, but for the universe. Liberty, like sunrays, has to embrace the entire world and invigorate nature in its entirety. The principles that were advanced do not belong to some exclusively privileged peoples, they are the property of the human species. But justice and liberty is not one and the same thing, and those who do not know how to be just, will never be free. ${ }^{70}$

Despite Boissy d'Anglas' professed commitment to universalism, spreading universal equality and liberty within the empire involved making clear distinctions. In America, he maintained, 'complete independence' is 'only possible on the continent'. 'Nature has promised liberty to the north of this hemisphere,

Colonies"', French Historical Studies 38 (2015), pp. 61-82; Spieler, 'The Legal Structure of Colonial Rule during the French Revolution'.

68 Boissy d'Anglas, 'Rapport et projet d'articles constitutionnels relatifs aux colonies, 17 Thermidor, An III (August 4, 1795), au nom de la Commission des Onze' (Speech to the National Convention), Gazette Nationale ou Le moniteur 322, pp. 415-420.

69 Boissy d'Anglas, 'Rapport et projet d'articles constitutionnels relatifs aux colonies', pp. 415, 420.

Ibid, p. 415 . 
and kept its word'. In the case of the slave insurrection of Saint-Domingue, Boissy d'Anglas noted, '[p]olitical independence was not the goal of their agitation' in the first place, but merely 'physical liberty'. The insurrectionist slaves 'have not longed for giving themselves leaders. ${ }^{71} \mathrm{He}$ characterized the island's inhabitants as 'softened by the influence of a constant and mild temperature' while effortlessly harvesting 'the richest gifts of the earth'. They did not aspire the kind of liberty 'that would cost them too much effort to retain', they were a people 'unable to retain its independence'. He concluded that such a people 'must therefore limit its wishes to being wisely and peacefully governed by humane and fair men.' ${ }^{72}$ Resonating the common trope that slaves were not prepared for unbridled liberty, Boissy d'Anglas held that 'having broken their chains', these 'tribes' were 'tormented by the same burdens of liberty'. Nonetheless, the inhabitants of the republican empire should be regarded as citizens: 'returning all the inhabitants of the colonies this liberty indistinctively, something which they were only able to delight in through violence and by force, is making them not only free men, but also citizens. To remove any remaining doubts, he reaffirmed the same point: 'The status of citizens is settled by the same constitution without exception. ${ }^{3}$ Thus, he envisioned what historians have called the French colonial theory of assimilation:

Let us tie the colonies to us through a wise and firm government [...] So that the colonies today are French instead of being solely American; that they are free, without, however, being independent; that they constitute a part of our indivisible republic, and that they are overseen ('surveillées') and ruled by the same laws and the same government [...] In this way you will allow the government to take the necessary action to pacify the regions and utilize them all according to the law both for the republic and for themselves; [...] being essentially assimilated in all other parts of the republic. ${ }^{74}$

Thus, the emancipation decree of 1794 was reaffirmed, while citizenship within the assimilated parts of the empire remained governed by a civic hierarchy based on civilizational inequality.

Boissy d'Anglas' seminal late eighteenth-century expression of what postrevolutionary citizenship, or perhaps more aptly, hierarchically structured

\footnotetext{
71 Boissy d'Anglas, 'Rapport et projet d'articles constitutionnels relatifs aux colonies', p. 418.

72 Ibid., p. 416.

73 Ibid., pp. 418, 420.

74 Ibid., p. 419 .
} 
post-revolutionary citizenships, in the French republican empire might look like exerted a powerful influence on the visions of empire in the nineteenth, and even the twentieth century. ${ }^{75}$ Whereas in the Charters of 1814 and 1830 it was ordained that the colonies should be ruled by royal ordinances and special laws, the 1848 Constitution fundamentally embraced the assimilationist ideal of one integrated indivisible empire. ${ }^{76}$ It is, however, fundamental to observe that during the 179os the main questions had already been formulated and the ideological groundwork laid out.

A similar vision of the French imperial assimilation was also put forth by the committed universalist the Abbé Grégoire who in the late 1790 and early 1800 s would continue to advocate new colonization projects in the African continent. ${ }^{77}$ 'Certainly France [...] could and should have brought civilization to the shores of Senegal, where, without regrets and without dangers, she could have created prosperous colonies with rich soil and closer to the mother country than the Antilles', he would write in his 1815 De la traite et de l'esclavage des noirs et des blancs. ${ }^{78}$ Earlier in 1796 , Grégoire had reconvened the Société des Amis des noirs - under the telling new name Société des Amis de Noirs et des Colonies. Although this club would hardly exercise any influence at the time and was finally suppressed in 1799, its antislavery and neo-colonialist outlook buttressed the idea of a republican empire. The first article of the society's mission statement read: 'The Society continues to occupy itself with the abolition of slavery, the moral and physical improvement (perfectionnement) of the inhabitants of the colonies; the progress of agriculture, industry, and commerce

75 R.F. Betts, Assimilation and Association in French Colonial Theory, 1890-1914, new ed. (Lincoln, NE: University of Nebraska Press, 2005, [1961]); C.R. Ageron, France coloniale ou parti colonial? (Paris: Presses universitaires de France, 1978), esp. ch. 6.

$76 \quad 1946$ saw the last expression of an assimilationist French 'Union', 'La République française une et indivisible', in which the colonies were defined as 'les territoires et fédérations d'outre-mer'. Ageron, France coloniale ou parti coloniale, pp. 190-195, 282-292; Cooper, Citizenship between Empire and Nation, pp. 67-124.

77 Sepinwall, The Abbé Grégoire and the French Revolution, pp. 149-155; Dorigny, 'Intégration Républicaine des colonies et projets de colonisation de l'Afrique'.

78 H. Grégoire, De la traite et de l'esclavage des noirs et des blancs (Paris: A. Égron, 1815), pp. 35-36 [French original: 'Certes la France, depuis long-temps, aurait pu et dù porter la civilisation sur les rives du Sénégal, où, sans remords, sans dangers, elle formeroit des Colonies prospères sur un sol luxuriant, et plus rapproché de la mère-patrie que ces Antilles'.]. Cf. P. Røge, 'Léconomie politique en France et les origines intellectuelles de la "mission civilisatrice" en Afrique', Revue Dix-huitième siècle 44 (2012), pp. 117-130; M. Dorigny, 'La société des amis des noirs et les projets de colonisation en afrique', Annales historiques de la Révolution françaice 293-294 (1993), pp. 421-429. 
in the colonies, and the formation of new colonies. ${ }^{79}$ While Grégoire as well as Condorcet in his Esquisse only vaguely alluded to neo-colonization as a means to spreading French civilization, more detailed and elaborated plans also circulated. They proposed economic relationships with Africans based on free labour and trade, a 'philantropic system of colonization', as one American newspaper called it. ${ }^{80}$ But whereas Grégoire and Condorcet were important exponents of a progressive and emancipatory pro-colonial mind set ultimately aimed at eradicating civic inequality within a greater French empire, the dominant pro-colonial - and until the abolition of slavery in 1848, pro-slavery French visions of empire would be governed by much fiercer hierarchical notions of civilizational and racial subordination. 81

Meanwhile, much had changed on the island between 1794 and 1801, the year Napoleon decided to send the largest naval military expedition force of his entire military career. The black general Toussaint Louverture, who had played a major role in defeating British invasion troops between 1794 and 1798, had become the dominant figure in Saint-Domingue. Under his leadership, a system of government was starting to take shape largely outside French control. Toussaint Louverture's decision to occupy Spanish Santo Domingo in January 1801 was a further indication that the leadership of Saint-Domingue was increasingly acting on its own without regard of the authorities in the

79 Règlement de la société des amis des noirs et des colonies, adopté dans sa Séance tenue à Paris le 30 Frimaire an VII (Paris: I'Imprimerie des sciences et arts, 1798), p. 5.

80 Most notably the writings of the Swedish publicist and member of the Société des Amis des Noirs et des Colonies Carl Bernhard Wadström: Especially his Essay on Colonization (London, 1794), translated as Précis sur les établissements des colonies de Sierra Leona et de Boulama à la côte occidentale d'Afrique (Paris: Pouyens, 1798); idem, Adresse au Corps législatif et au Directoire exécutif de la République française (Paris, Imprimerie des sciences et arts, 1795). Greenleaf's New York Journal and Patriotic Register of November 28, 1798, wrote about the Council of Five Hundred examining the idea of 'philantropic colonization' and also identified 'Mr. Wadstrom' as the mind behind it. On Wadström, see J. Ahlskog, 'The Political Economy of Colonisation: Carl Bernhard Wadström's Case for Abolition and Civilisation', Sjuttonhundratal: Nordic Yearbook of Eighteenth Century Studies, (2010), pp. $146-168$.

81 Røge, 'L'économie politique en France et les origines intellectuelles de la "mission civilisatrice" en Afrique'; Dorigny, 'La société des amis des noirs et les projets de colonisation en Afrique'; B. Gainot, 'La Décade et la "colonisation nouvelle", Annales historiques de la Révolution française 339 (2005), pp. 99-116; W.B. Cohen, The French Encounter with Africans: White Response to Blacks, 1530-1880 (Bloomington, IN: Indiana University Press, 1980), pp. 155-180. For late nineteenth and early twentieth-century developments, see Conklin, $A$ Mission to Civilize; Cooper, Citizenship between Empire and Nation; D.B. Marshall, The French Colonial Myth and Constitution-Making in the Fourth Republic (New Haven, CT: Yale University Press, 1973); Wilder, The French Imperial Nation-State. 
motherland. But it was in particular Toussaint Louverture's commissioned drafting of a constitution without permission from Paris that angered Napoleon (he received a printed copy of it). There is no doubt that Napoleon by sending a 20,000-soldier strong naval force under the command of his brother-inlaw General Charles Leclerc wanted to restore France's supreme political authority in its empire. Recent scholarship, however, has suggested that it would be too simplistic to see Napoleon's military expedition of 1801-1802 as a straightforward attempt to restore slavery driven by an influential colonial lobby which in turn was motivated by a uniform ideological pro-slavery agenda. ${ }^{82}$ Instead, it seems to have been a mission much more dictated by strategic and pragmatic considerations on the part of Napoleon and his military officials.

Yet, although the strict causal links between pro-slavery thought and Bonaparte's imperial policies might indeed appear to be quite weak, it is undeniable that in this period the revolutionary conceptual triad relationship of empirerights-citizenship dissolved. With Bonaparte's seizure of power in 1799, France's imperial policies took a decidedly anti-emancipatory turn. ${ }^{83}$ The vision that anyone within the constituted political space of a republican empire could ultimately obtain the status of citizen, as long as one had reached a certain benchmark of civilization and enlightenment, was brushed aside. The constitution of Year VIII (1799), brought into force after Napoleon's ascendance, unambiguously abandoned the idea of a single imperial constitutional order, as it explicitly stipulated that "The regime of the French colonies is determined by special laws'. It soon became clear that Bonaparte was not intent on enforcing the 1794 decree assigning citizenship to black slaves in France's Indian Ocean colonies where white planters had successfully resisted its implementation. Significant is the fact that the new constitution did not include a declaration of rights. France's imperial policy became fundamentally detached from the discourse of the rights of man and citizen.

$82 \quad$ P.R. Girard, 'Napoléon Bonaparte and the Emancipation Issue in Saint-Domingue, 17991803', French Historical Studies 32 (2009), pp. 587-618; P.R. Girard, The Slaves who defeated Napoleon: Toussaint Louverture and the Haitian War of Independence, 1801-1804 (Tuscaloosa, AL: University of Alabama Press, 2011); Dubois, A Colony of Citizens, pp. 351-352; Popkin, A Concise History of the Haitian Revolution, pp. 116-120.

83 The principal publications on this episode include Y. Bénot, La démence coloniale sous Napoléon (Paris: Editions La Découverte, 1992); Y. Bénot and M. Dorigny (eds.), Rétablissement de l'esclavage dans les colonies françaises. Aux origines de Haïti (Paris: Maisonneuve et Larose, 2003); P. Branda and T. Lentz, Napoléon, l'esclavage et les colonies (Paris: Fayard, 2006). Miranda Spieler sees much continuity between Napoleon's imperial regime and the 1795 constitution. Spieler, Empire and Underworld, pp. 54-58. 
Napoleon's re-establishment of slavery on 20 floréal Year X (May 10, 1802) was accompanied by what Yves Bénot has called a 'wave of proslavery propaganda'. The presumed civilizational degeneratedness of black Africans would be invoked time and again in these writings. This pro-slavery public opinion built on what conservative spokesmen of the planters and merchants class had kept repeating in the second half of the 1790s, namely that 'the exercise of citizenship can only belong to a civilized population', not to 'savages' and 'primitive races' ${ }^{84}$ Charpentier-Cossigny, a slave-owner from Île-de-France, stated that 'Raising a barbaric people to civilization is not a one-day affair'. ${ }^{55}$ In debates in the Tribunat (one of the four assemblies set up by the constitution of year 1799), during the build up to the decree reinstituting slavery, the language of civilizational backwardness could be heard everywhere. Pierre-August Adet, diplomat, and former secretary of the Ministry of the Navy and the Colonies, who had been sent to Saint-Domingue in 1791 to put down the slave rebellion, commented on the abolition act of 1794: 'Was this partial emancipation not the signal of a general insurrection and the devastation of the colonies?' He went on to point out the parallel between the failure of revolution within $\mathrm{Eu}-$ ropean civilization and the one in the Caribbean: " $[\mathrm{W}] \mathrm{e}$ had the suffering to see in our country, within European enlightenment and civilization, men who could not distinguish between the rights granted by liberty $[\ldots]$ and the cruelty of savage tyranny with the noble prerogatives of liberty'. Adet could not imagine how 'the obscurity of a child' can abruptly transform from slavery to liberty. Such a step would require 'sentiments' that have benefited from 'example and education'. Men 'who have no idea' of the 'voluntary obedience which characterises the citizen' will 'break the yoke of laws imposed on them', and this in the end leads to 'scenes of blood and carnage. ${ }^{86}$

A similar dismissal of the universalist citizenship ideals was made by the French councillor of state Étienne Eustache Bruix, a former French navy admiral and minister of the navy and colonies, when introducing the slavery law of May 20, 1802, in the Corps legislative. Bruix's speech was published in several

\footnotetext{
84 The quote is taken from a mémoire drawn by Bordeaux merchants from June 19, 1797: 'Mémoire des négociants de Bordeaux sur les colonies', as cited in: Dubois, A Colony of Citizens, p. 290.

85 Charpentier-Cossigny, Moyens d'amélioration et de restauration proposés au gouvernement (1803) I, pp. 275-276, as cited in: Bénot, La démence coloniale sous Napoléon, p. 201.

86 Gazette nationale ou le moniteur universelle, no. 240, 30 Florial an X (May 20, 1802), pp. $981-988$, at p. 988 .
} 
American newspapers, accompanied by the headline 'Africans again doomed to slavery!: 87

It is known to you in what manner the illusions of liberty and equality have been propagated in those remote countries, where the striking difference between the civilized and the uncivilized man, the difference of climate, colors and habits, and principally, the security of European families, imperiously required a great inequality in the civil and political state of individuals [...] It is also known what has been the fatal consequence of these innovations, so eagerly pursued by zealots, most of whom were doubtless actuated by the honorable intention of promoting the cause of humanity, and who, while endeavouring to render the inhabitants indiscriminately equal in rights have only rendered them equally unhappy. ${ }^{88}$

And finally, Napoleon himself echoed this kind of rhetoric, wondering 'How anyone could have granted freedom to Africans, to men who did not have any civilization, who did not even know what a colony was, or what France was?'89 Napoleon's remark shows that he not only related black people to 'African' civilizational backwardness, but also that he could not imagine them to be - or become - part of a French nation une et indivisible.

To be sure, the supposed degeneratedness of black Africans was not only expressed in terms of civilizational backwardness. As Andrew Curran recently has suggested, from the first decade of the nineteenth century onwards the discourse on the 'nègre' in France also underwent a renewed 'widespread scientific racialization' that posited deterministic schemas of black people's cognitive and mental inferiority. This kind of thinking had its roots in racial classification schemas. Louis Narcisse Baudry Des Lozières, a ruined SaintDominguan planter, for instance, considered it as 'natural evidence' that the black species is 'depraved' ('dépravé') or 'degraded' ('avilie'), contending 'that it is the most imperfect class of humanity, the darkest, the least capable of

87 According to the Albany Centinel (Albany, New York) of July 13, 1802, Bruix's speech was translated from an article from a newspaper from Le Havre of May 20. It also appeared in: The Independent Chronicle (Boston, Massachusetts) July 12, 1802; Middlesex Gazette (Middletown, Connecticut), July 12, 1802; The Sun (Pittsfield, Massachusetts), July 19, 1802; Republican Gazette (Concord, New Hampshire) July 27, 1802. The quote is taken from the Republican Gazette.

88 Republican Gazette (Concord, New Hampshire) July 27, 1802.

89 J.J. Damas-Hinard (ed.) Napoleon, ses opinions et jugemens sur les hommes et sur les choses, 2 vols. (Paris: Duféy, 1838), vol. 1, p. 256. 
enlightenment, the most vicious, the least correctable. ${ }^{90}$ In a climate in which public sympathy for the blacks in Saint-Domingue waned, more racialized understandings of black people drawing on biology, natural history, and polygenetic theories of the origins of the human race(s) 'intersected', as Curran put it, with proslavery advocates' denunciations of the radical egalitarianism of the Société des Amis des Noirs and the barbarity of black insurrectionists in SaintDomingue ${ }^{91}$ René Chateaubriand's oft-cited quote in the midst of the military confrontation between France and Saint-Domingue speaks volumes: ' $[\mathrm{F}]$ or the Negroes of our colonies [...] even pity has extinguished; for who would still plead the cause of the blacks after the crimes they have committed?'92

In a letter of September 1802 to Minister of the Navy Denis Decrès (under the First Consulate), Jean-Baptiste Raymond de Lacrosse, governor of the French Caribbean colonies Martinique and Guadaloupe, captured the spirit in which the ideal of equal imperial citizenship was abandoned. Lacrosse wrote that the slave insurrection provides

the lessons that must illuminate the government more than theories whose unreflected application most often contradicts our hopes [...] The true liberty of civilized man was not made for the nègres of the French colonies. This gift was disastrous in its results not only to those whom it was given but also to the metropole, which wanted to take them out of a state of degradation rejected by the philanthropists. Those times of enthusiasm have ended. ${ }^{93}$

$90 \quad$ L.N. Baudry Deslozières, Les égarements du nigrophilisme (Paris: Migneret, 1802), p. 109. On Baudry Deslozières, see C. Wanquet, 'Un Réquisitoire contre l'abolition de l'esclavage: Les Égarements du nigrophilisme de Louis Narcisse Baudry Deslozières (Mars 1802)', in: Bénot and Dorigny (eds.) Rétablissement de l'esclavage dans les colonies françaises, pp. 29-50.

91 Curran, The Anatomy of Blackness, p. 213.

92 M. le vicomte de Chateaubriand, Génie du Christianisme (1802) in: idem, CEuvres Complètes, 5 vols. (Paris: Didot, 1842), vol. 3, p. 235. Cf. Mercure de France 22 (April 1805), p. 441: 'Those who wish the destruction of our colonies [now] understand that it is no longer possible to plead the cause of this barbarian race with success'. As cited in: Curran, The Anatomy of Blackness, p. 210.

93 Letter of Lacrosse to Minister Decrès (September 23, 26, 1802). As cited in: Dubois, A Colony of Citizens, p. 411. 


\section{Uniting 'good' Citizens in Thermidorian France}

On September 20, 1794, a little less than two months after the fall of Robespierre on 9 Thermidor Year II (July 27, 1794), representative Jean-Baptiste Robert Lindet presented to the National Convention on behalf of the committees of Public Safety and General Security a report 'On the internal situation of the Republic.'. It was a strained report. How else could it be? Having gone through the experience of what has come to be known as the Jacobin Terror of 17931794, France was still gasping for breath and was only beginning to 'recollect the events the memory of which ought never to be effaced', as the report put it. These events, Lindet purported, 'will be a useful lesson for us and for posterity'. For ' $[t]$ he representatives of the people ought not only to pass on to posterity their actions, their glory and their success; they ought to pass on to them the knowledge of dangers, misfortunes, and errors. ${ }^{2}$

What were these dangers, misfortunes, and errors? And could the Terror represent all these things at once? For weeks the streets had been flooded with anti-Jacobin pamphlets, as the freedom of press was re-established. Gradually, more and more atrocities came to light; Jacobins were denounced everywhere; Robespierre was portrayed as a 'tyrant' and bloodthirsty monster; militias of vengeful anti-Jacobin groups of young men scoured the streets of Paris, while thousands of often equally vengeful prisoners were released within less than a month. The downfall of Robespierre set in motion a process of public exorcism that could hardly be kept under control by the National Convention that eagerly tried to re-establish its status as the supreme political authority above that of the committees and the Jacobin Club. ${ }^{3}$ It was an extremely vexed and complex process. Many who now renounced Robespierre and the

1 R. Lindet, Rapport fait à la Convention nationale dans la séance du 4ème des Sans-Culottides de l'an zème, au nom des Comités de salut public, de sûreté générale et de législation, réunis, sur la situation intérieure de la république, par Robert Lindet, Représentant du peuple, et membre du comité de salut public (Montauban: Chez Fontanel, imprimeur de la société populaire, an III [1795]). Quotations are taken from: A. Amic and E. Mouttet (eds.) La tribune française: choix des discours et des rapports les plus remarquables prononcés dans nos assemblées parlementaires depuis 1789 jusqu'à 1840, 2 vols. (Paris: Bureaux de la tribune française, 1840), vol. 2, pp. 605-621.

2 Lindet, Rapport fait à la Convention nationale, p. 607 .

3 On this period, see B. Baczko, Ending the Terror. Insightful observations can also be found in F. Gendron, The Gilded Youth of Thermidor, trans. J. Cookson (Montreal: McGill-Queen's University Press, 1993). 
Terror - including Lindet - had been fully implicated in his ascent to power, and were, to varying degrees, jointly responsible for the atrocities committed in the name of the Revolution. Scapegoating Robespierre was a convenient strategy for political survival. 'Turncoat terrorists' such as Jean-Lambert Tallien and Louis-Marie-Stanislas Fréron who wholeheartedly embraced the 'Thermidorian reaction' simultaneously tried to find a new political equilibrium - or more cynically put: tried to take hold of power - and secure their own personal safety. Vengeance and reconciliation, selective amnesia, bringing people to justice, mourning the past and projecting a new future, exorcism and internalization; all these - often conflicting - emotions, socio-psychological processes, and shifts in political power and discourse took turns, or were simultaneously at play, in the weeks and months that followed Robespierre's fall. ${ }^{4}$

As Bronisław Baczko and Sergio Luzzatto have argued, Thermidor was first and foremost the moment when leading French politicians came to the realization that the French Revolution could no longer be considered a uniform experience. The Revolution had become a 'many-headed monster', Thermidor an 'unforgiving mirror. 5 Crucially, the monster's heads were not merely parasitic aristocrats, refractory clerics, stubborn ancien régime monarchists, or hostile foreigners. They also came from within the revolutionary republic's own echelons, that is to say, from the ranks of 'citizens'. Hence, the Terror and its aftermath, as this chapter shows, generated a discourse of the 'good citizen' in opposition to the 'bad citizen'. The Thermidorian 'reaction', then, was not a counterrevolution, but a reaction of citizens against (other) citizens. How was the notion of 'good citizen' reinvented against this background of figuring out a post-Terror social and political order? Could the revolutionary key concept of republican citizenship be maintained after the experience of the Jacobin Terror, and if so, how? 6

4 See Mona Ozouf's essay 'Thermidor ou le travail de l'oubli', in: M. Ozouf, L'École de la France: Essais sur la Révolution, l'utopie et l'enseignement (Paris: Gallimard, 1984), pp. 91-108. For an interpretation of Thermidor from the perspective of transitional justice, see H.G. Brown, 'Robespierre's Tail: The Possibilities of Justice after the Terror', Canadian Journal of History 45 (2010), pp. 1758-94.

5 Luzzatto, L'automne de la Révolution, pp. 341-343; Baczko, Ending the Terror, pp. 124, 250.

6 It has been a commonplace of the 'classical interpretation' of French Marxist historians Albert Mathiez, Georges Lefebvre, and Albert Soboul to characterize the Thermidorian and Directorial regimes predominantly as conservative reactions to the unfortunate excesses of the Terror. In their rendering, $1795^{-1799}$ was an 'interlude' between Jacobin democracy and Napoleonic dictatorship, vexed by multiple crises, corrupt and greedy politicians, and a politically unstable basis ultimately destined to end in dictatorship. On their account, and of 
Focusing on 1794-1795, this chapter examines how the Thermidorian centre sought to remodel citizenship. First, I highlight some aspects of the revolutionary political culture of citizenship between 1792 and 1794 so that we can better understand what Thermidorian politicians and publicists were reacting against. I then analyse how centrist Thermidorians tried to detach the citizen from the most important platform of participatory and radical politics: the political clubs. Through restraining, policing, and ultimately closing down 'popular societies' (although they did not disappear entirely and were shortly tolerated in 1797-1798), the Thermidorian centre sought to isolate the citizen politically. Second, they invested the meaning of citizenship with depoliticized ideals: the 'good citizen' ought to redirect his energy away from politics to 'society', that is to say, to labour and industry, commercial activities, and the arts and sciences. Finally, good citizenship became a more pronouncedly restrictive category reserved for educated or enlightened property-owners.

None of these arguments were entirely new. As early as September 1791, the phenomenon of popular societies had been criticized as unsound intermediary bodies between the individual citizen and its national representation. ${ }^{7}$ Equally, the claim that citizens in large commercial states ought to direct their energy towards agriculture, industry and commerce, societal life, and the arts and sciences, instead of relentlessly devoting themselves to politics and the common good as in the ancient republics, was not particularly new. ${ }^{8}$

those working within that tradition, the regime following Thermidor was a (return to the) 'bourgeois republic' with its elitist conception of a propertied bourgeois citizen; it thus signified the ideological betrayal of the principles of genuine social democracy, true equality and natural rights. Baczko's seminal 1989 essay Comment sortir de la Terreur fundamentally shifted the terms of interpretation and breathed new life into the study of political discourse after the Terror. Instead of a second order interlude, he remade the Thermidorian period into an integral part of the dynamic of revolution. Baczko argued that the Thermidorian period's fundamental struggle was 'how to bring the Terror to an end', but insisted that this involved coming to grips with the Terror as well as trying to devise a 'political and institutional arena that needed to be created for after the Terror'. See Baczko, Ending the Terror, and for a recent overview, Laura Mason, 'The Thermidorian Reaction', in: P. McPhee (ed.) A Companion to The French Revolution (Malden, MA: Wiley-Blackwell, 2012), pp. 313-327. For the classical interpretation, see A. Mathiez, La Réaction thermidorienne (Paris: Armand Colin, 1929); G. Lefebvre, Les Thermidoriens (Paris: A. Colin, 1937). A. Soboul, De Franse Revolutie, 2 vols., trans. C. Jongenburger (Amsterdam: Van Gennep, 1979), vol. 2: 1793-1799, pp. 353-402.

7 P. Rosanvallon, The Demands of Liberty: Civil Society in France since the Revolution, trans. A. Goldhammer (Cambridge, MA: Harvard University Press, 2007), pp. 16-21; Baczko, Ending the Terror, pp. 102-104.

8 Arguably, the most important theoretician of this view was the abbé Sieyès. W.H. Sewell, A Rhetoric of Bourgeois Revolution: The Abbé Sieyes and 'What Is the Third Estate?' (Durham, N.C.: Duke University Press, 1994), pp. 66-108; R. Whatmore, Republicanism and the French 
Finally, with the contention that (full-fledged political) citizenship in principle ought to be reserved for educated or enlightened property-owners, centrist Thermidorians did not break new ground either. ${ }^{9}$ Yet, all these understandings of citizenship gained new relevance and urgency, and were mobilized with explicit reference to the experience of the Terror. The point is that the context in which these elements were expressed as components of a renewed understanding of 'good citizenship' had radically changed. The revolutionary experience, and the Terror in particular, had produced different 'citizenships'. Put differently, there were now different citizenships for a large modern republic on offer. ${ }^{10}$ As Lindet put it, it was now up to post-Terror revolutionaries to

Revolution. An Intellectual History of Jean-Baptiste Say's Political Economy (Oxford: Oxford University Press, 200o), pp. 68-82; M. Sonenscher, 'Introduction', in: Sieyès, Political Writings, including the Debate between Sieyès and Paine in 1791, trans. M. Sonenscher (Indianapolis, IN: Hackett, 2003), vii-lxiv; and Gordon, Citizens without Sovereignty. Girondins like Brissot had no elaborate conception of democratic participation. See R. Whatmore and J. Livesey, 'Etienne Clavière, Jacques-Pierre Brissot, et les fondations intellectuelles de la politique des Girondins', Annales historiques de la Révolution française 3 (2000), pp. 1-26.

9 See K.M. Baker, 'Political Languages of the French Revolution', in: Goldie and Wokler (eds.) The Cambridge History of Eighteenth-Century Political Thought, pp. 626-659, esp. 639-642.

10 Recently, Andrew Jainchill and James Livesey have highlighted currents of Thermidorian and Directorial French political thought that have their origins, they claim, in early modern republicanism, although they differ in their understanding of the nature of postTerror republicanism. According to Jainchill's influential study, 'the political culture of post-Terror France' was 'fundamentally defined by a classical-republican language of politics', that is, a classical-republican language as understood within the Atlantic tradition described by J.G.A. Pocock, and rooted in classical antiquity. Jainchill claims that the postTerror republican centre rejected Jacobin democracy, sought to restrain and diminish the importance of popular sovereignty, and championed a constitutional order in which civil liberties and property were to be protected; but they did so within a fundamentally classical-republican 'conceptual matrix'. Livesey, on the other hand, sees 1794-1799 as the breeding ground of 'commercial' republican ideals and 'democratic practices', and makes the remarkable claim that it was during these five years that 'a democratic culture was created, that the norm of democracy found content'. In my view, both authors overstate their case. In the Thermidorian centre's diagnosis of the French Republic and their proposals to remedy its decline, elements of the language of classical republicanism were certainly there. Yet, post-Terror republican thinkers and politicians were deeply aware that the emergence of modern commercial society - and almost a century of inexhaustible theoretical reflection upon it - had reoriented the classical-republican ideals of old. To say on the other hand, as Livesey does, that during these years a 'new democratic republicanism' based on 'universal rights' was established, runs counter to much historical evidence that suggests the contrary: the (re-)introduction of a two-tier voting system (instead of direct elections), the two-thirds decree of 1795 (ensuring the continuity of twothirds of the members of the National Convention), low voter turnouts, the frontal attack 
decide what 'dangers, misfortunes, and errors' should be avoided, and what elements of revolutionary citizenship should be maintained.

Ultimately, I argue that the way for post-revolutionary, Napoleonic subjecthood was partly cleared by the intellectual construction - and its failure - of a more exclusive, isolated and depoliticized 'good citizen' under the cloak of an undivided, anti-pluralist nation, as opposed to the 'bad citizen' of the factional Jacobin Terror. ${ }^{11}$

In the early morning of August 10, 1792, a large crowd of urban and provincial insurrectionists led by the Commune, the revolutionary municipal government of Paris, marched the royal Tuileries palace on the bank of the Seine. The palace had been the official residence of Louis XVI and his family since their forced departure from Versailles in October 1789 . The king rushed to take refuge in the Legislative Assembly. Under siege of the militant demonstrators, the Assembly saw no other alternative than suspending the monarch. The journée of 10 August 1792 thus marked the end of the French constitutional monarchy and the birth of the French Republic, which was officially inaugurated on September 21, 1792. As the Legislative Assembly was deposed shortly after the king's suspension, the revolutionary intervention was also a forthright repossession by 'the people' of its sovereignty from representative government. The French republic was born, at least in the public imagination, from an act of direct popular democracy. ${ }^{12}$

In the weeks following the suspension of King Louis XVI elements were put in place that foreshadowed and would come to be identified with the Terror:

on popular societies, and two coups in September 1797 and May 1798 annulling election results. In short, it requires quite a stretch to see this period as the breeding ground of 'democratic values'. See A., Jainchill, Reimagining Politics after the Terror: The Republican Origins of French Liberalism (Ithaca, N.Y.: Cornell University Press, 2008), pp. 10, 22; J. Livesey, Making Democracy in the French Revolution (Cambridge, MA: Harvard University Press, 2001), pp. 12-13, 234.

11 Howard G. Brown has convincingly demonstrated how the Directory's repressive judicialmilitary practices paved the way for a more submissive and passive form of citizenship under Napoleonic authoritarianism. This chapter suggests that if we wish to understand the emergence of a depoliticized ideal of the 'good citizen', we need to ask what specific meanings and ideals were invested in it in the aftermath of the Terror. See H.G. Brown, Ending the Revolution: Violence, Justice, and Repression from the Terror to Napoleon (Charlottesville, VA: University of Virginia Press, 2006). 
the establishment of surveillance committees and special revolutionary tribunals, the arbitrary arrestment of suspicious individuals, and the deportation of refractory clergymen refusing to take the revolutionary clerical oath. In the panic resulting from the threat of invading armies in early September 1792 a series of chaotically executed massacres took place in Paris prisons. ${ }^{13}$

The founding moment of the French Republic coincided with the dramatic victory of the French revolutionary army against the Austro-Prussian army of the Duke of Brunswick at Valmy on 20 September. The day after the victory, the republic was officially proclaimed. It lent the military triumph a highly symbolic meaning. A republican army of citizen-soldiers, a 'nation in arms', was able to defeat the forces of (royalist) evil in an apocalyptic battle of international proportions. ${ }^{14}$ The sense of a free, revolutionary republic fighting enemy forces of royal despotism only increased when in early 1793 the French Republic declared war to England, Spain, and the Dutch Republic. In March 1793, a massive rebellion in the Vendée followed by federalist insurrections in the Summer proved to many French revolutionaries that the republic was not only surrounded by external foreign enemies, but also faced a hostile counterrevolutionary column from 'within'.

This was the political and mental environment in which the French republic inaugurated a new phase in the revolutionary political culture of citizenship. Universal male suffrage for all men aged twenty-one or over (except domestic servants) was introduced, the distinction between 'passive' and 'active' citizens abandoned. The urban lower classes and the militant sans-culottes organized in the Parisian sections and popular societies who had played a decisive role in the insurrection of August 10, grew into a serious political force to be reckoned with. Within the newly elected National Convention, the Jacobins rose to power; outside the Convention, the number of Jacobin clubs throughout France grew spectacularly between August 1792 and the Spring of 1794 . Popular societies, the Jacobin clubs most prominently, became crucial platforms of citizen political activism. Furthermore, the war mobilization of the nation, reaching its high point in the levée en masse (mass military conscription of all able men) decreed on August 23, 1793, led to an unprecedented militarization of society: citizens were expected to be soldiers, and vice versa. This

13 During the so-called 'September Massacres' of 2-6 September, between 1,100 to 1,400 prisoners were massacred. See Pierre Caron, Les massacres de septembre (Paris, 1935); T. Tackett, 'Rumor and Revolution: The Case of the September Massacres', French History and Civilization 4 (2011), pp. 54-64.

14 D.A. Bell, The First Total War. Napoleon's Europe and the Birth of Warfare as We Know It (Boston: Houghton Mifflin Harcourt, 2007), pp. 133-138. 
war time mobilization went hand in hand with a growing appeal to classicalrepublican imagery and a rhetoric of virtue, sacrifice, and martyrdom, as displayed in songs, civic festivals, and theatre. ${ }^{15}$

The new political culture of citizenship was, moreover, characterized by an increased public scrutiny of citizen behavior. In the Spring of 1793, when the Republic's fortunes seemed at a low point with the outbreak of the Vendée revolt and defeat against the Austrians in the Southern Netherlands, the Committee of Public Safety was instituted as the focal point of a more and more centralized government. An extraordinary law court, the Paris Revolutionary Tribunal, was established to try and convict counterrevolutionary forces. On March 21, the Committee of Public Safety ordered communes to establish surveillance committees to scrutinize strangers, check, inspect, and draw up lists of suspects, and issue 'civic certificates' (certificats de civisme) to those citizens who had proven their civic virtue and patriotism. Jacobin clubs would come to play an important role in setting up such committees, staffing them, and eventually, issuing the civic certificates. Citizenship was attributed special, highlydemanding moral and political duties. The Law of Suspects of 17 September 1793 declared that anyone who was refused a civic certificate was deemed a 'suspected person'. Permanent vigilance, distrust, and accusations characterized the new revolutionary civic culture.

The network of corresponding Jacobin clubs was one of the central pillars of the revolutionary government and political culture of 1793-1794. Originally founded in 1789, the 'Society of Friends of the Constitution' (which had grown out of the Versailles-based Breton Club) began as a parliamentary political pressure group where likeminded deputies of the National Assembly would prepare the following day's sessions. It was soon dubbed the 'Jacobin' club, referring to the Jacobin Convent at the Rue Saint-Honoré in Paris where the society held its meetings. ${ }^{16}$ Initially open for deputies of the National Assembly only, it soon welcomed non-deputies to its ranks. Affiliated clubs sprang up throughout the country over the next two years, numbering almost 1,00o clubs at the disbandment of the National Constituent Assembly on 30 September 1791. Although there were local variations, Jacobin clubs turned into schools for revolutionary education or 'schools for political culture' as Patrice Gueniffey and Ran Halévi put it, as well as training grounds for politicians. ${ }^{17}$ After the

\footnotetext{
15 M. Ozouf, La fête révolutionnaire, 1789-1799 (Paris: Gallimard, 1976).

16 M.L. Kennedy, The Jacobin Clubs in the French Revolution. Volume 1: The First Years (Princeton, N.J.: Princeton University Press, 1982).

17 P. Gueniffey and R. Halévi, 'Clubs and Popular Societies', in: Furet and Ozouf (eds.) Critical Dictionary, pp. $45^{8-473}$, at p. 459 .
} 
king's flight to Varenne, unrepairable divisions of opinion within the Parisian Jacobin Club led to the exodus of more moderate deputies advocating a constitutional monarchy (who would subsequently form their own Feuillants society). Opening their meetings to the general public in October 1791, the societies gradually turned into an autonomous political power, and through its corresponding committees and symbiotic relationship with the press, into a source of public opinion formation, popular mobilization, and political action.

It should be born in mind that the Jacobin clubs were one species among a plethora of popular societies that mushroomed between 1789 and 1795 . Although it was rivalled in the early years by the constitutional-monarchist Amis de la Constitution Monarchique and the Société des Amis de la Constitution of the Feuillants (moderate ex-Jacobins), the Jacobin Club established itself as the most important and by far the most influential one. Patrice Higonnet has suggested a tripartite division between, first, the Jacobin clubs proper; second, sociétés populaires; and third, the (urban) section assemblies (assemblées sectionnaires). The section assemblies were strictly speaking not voluntary societies, but legally constituted representative assemblies of urban geographical and administrative units (that would replace the older 'districts' in May 1790). Until September 1792 only active citizens with the right to vote were officially allowed entrance. But precisely the legal restrictions of the section assemblies prompted the creation of alternative platforms of citizen activity: popular societies with low entrance fees and minimal membership restrictions. Founded in late April 179o, the populist left-wing Société des Amis des droits de l'homme et du citoyen or Club des Cordeliers, in which George Danton, Jean-Paul Marat, and Camille Desmoulins played crucial roles, is perhaps the most famous example of such popular societies. ${ }^{18}$ The elite societies of the constitutional monarchists and Feuillants of the early years of the French Revolution had little in common with the popular societies such as the Club des Cordeliers. While the Jacobin clubs were initially manned by those from upper middleclass and middle-class professions (some being more elitist than others), after August 1792 some clubs lowered entry requirements. Yet alongside the Jacobin clubs there were numerous sometimes rivalling, more 'popular' societies.

In late 1792, the Jacobin Club again split, now into the Girondins under the leadership of Brissot and the energetic, radical left-wing Montagnards ('Mountaineers'; deputies who grouped at the top benches of the Assembly's meeting hall). The dramatic polarization between the Montagnards and the Girondins

18 On the popular societies in Paris sections, see R.B. Rose, The Making of the Sans-culottes: Democratic Ideas and Institutions in Paris, 1789-92 (Manchester: Manchester University Press, 1983), pp. 96-165. 
resulted in the expulsion of the Girondins in the journées of 31 May-2 June 1793. From June 1793 until the fall of Robespierre on July 26, 1794 (8 Thermidor Year II in the French Republican Calendar), the Montagnard faction would dominate French revolutionary politics. The expanding number of Jacobin clubs turned into the political instrument of the radical Montagnard faction. In the Spring of 1794, according to some estimations, revolutionary France as a whole counted roughly 6,00o 'popular societies'. So-called représentants en mission, government officials that were sent to the provinces and played an important role in the execution of acts of terror, were mostly recruited from Montagnard ranks. Nearly all members of the Committee of Public Safety and General Security, the executive bodies of the revolutionary government were drawn from the Jacobins. The Jacobin clubs had evolved from vessels of revolutionary education and parliamentary pressure into informal government agencies with executive power. They increasingly received their instructions from the Paris based mother society, while closely cooperating with the représentants en mission. ${ }^{19}$ By 1794 the clubs had become arms of the government apparatus. ${ }^{20}$

In the Spring and Summer of 1794 revolutionary justice was centralized in Paris. The infamous decree of 22 Prairial II (10 June 1794) gave the Revolutionary Tribunal virtual omnipotence as it denied the accused recourse to a lawyer, an open hearing, and the possibility of calling up witnesses. Anyone categorized as 'enemy of the revolution' or 'the people', or more generally still, as 'hostis humani generis' (enemy of the human race), could become a victim of the Terror: nobles, clerics, counter-revolutionaries, resistant peasants, foreign intruders and foes, and more generally anyone suspected of conspiring against the Republic, including those in the highest echelons who had wholeheartedly supported the Montagnard regime, most notably Georges Danton, Jacques Hébert, and their followers. Under the authority of the Committee of Public Safety, the executive branch of the National Convention, between 35,000 and 40,000 people fell victim to the regime's repressive violence and atrocities. Around 16,6oo victims were sentenced to death by revolutionary courts, approximately 500,000 individuals were imprisoned. ${ }^{21}$

Despite the scale, gruesome excesses, 'extra-legal' processes and executions, and installation of extraordinary tribunals, a wave of recent scholarship has

19 There were, however, many regional variations and provincial Jacobin clubs did not simply follow commands from Paris. I. Woloch, The New Regime. Transformations of the French Civic Order, 1789-1820s (New York, N.Y.: Norton, 1994), pp. 78-81.

$20 \quad$ L. Jaume, Le discours jacobin et la démocratie (Paris: Fayard, 1989), pp. 45-144.

21 Figures are taken from C. Jones, The Longman Companion to the French Revolution (London: Longman, 1988), p. 115. 
argued that it makes no sense to speak of the 'reign' or a 'system' of Terror. Such characterizations, this body of scholarship suggest, fail to make clear analytical distinctions between uncontrolled mob violence, executions by (flawed and arbitrary) 'legal' processes, 'emergency measures' necessary to avert the dangers of foreign invasion, (domestic) counter-revolution and regional insurrections, and all kinds of supposed (and real) conspiracies against the Revolution. Instead, the Terror, or 'recourse to terror', was above all a drastic, fear-driven instance of evolving wartime politics, not an ideology-driven, proto-totalitarian politics emanating from a rousseauist notion of 'general will'. ${ }^{22}$ There is no monocausal explanation connecting the revolutionary political culture of citizenship and the Terror.

But contemporaries did not enjoy the benefit of hindsight. In fact, as the following chapters show, many who on either side of the Atlantic reflected on the radical phase and political violence of the French Revolution of 1792-94 did come to associate aspects of this revolutionary political culture of citizenship with the Terror - or consciously tried to forge a relationship between them.

\section{Good Citizen / Bad Citizen}

What were the assumptions and framework of the evaluation of the Terror from which the post-Terror 'good citizen' concept sprang? The report of Robert Lindet, a moderate ex-Montagnard, member of the Committee of Public Safety, Représentant en mission in Normandy, and high government official in the National Food Commission, is an instructive starting point as it reflects the ambiguous immediate post-Terror climate. Lindet's report, which was welcomed with much enthusiasm in the National Convention, has been characterized by Baczko as both a 'balance-sheet', marking a 'pause' in the early emergence from the Terror, and a premature formulation of a 'centrist' program for the future. ${ }^{23}$ Lindet's was a strained call for unity, trying to rally as

22 D. Andress, The Terror: Civil War in the French Revolution (London: Little, Brown, 2005); J.-C. Martin, Violence et revolution: essai sur la naissance d'un mythe national (Paris: Seuil, 2006); T. Tackett, The Coming of the Terror in the French Revolution (Cambridge, MA: Harvard University Press, 2016). In his synthetic history of the French Revolution, Peter McPhee reaffirms this line of interpretation. P. McPhee, Liberty or Death. The French Revolution (New Haven, CT:Yale University Press, 2016). The phrase 'recourse to terror' is Marisa Linton's. See her 'Terror and Politics', in: D. Andress (ed.) The Oxford Handbook of the French Revolution (Oxford: Oxford University Press, 2015), pp. 471-486.

Baczko, Ending the Terror, pp. 115-125. 
much Frenchmen as possible behind the National Convention to the exclusion of extremists. It spoke out vehemently against unchecked vengeance against former perpetrators (which was not entirely without self-interest). In the long run, Lindet's early call for unity and reconciliation failed miserably. If anything, the Thermidorian period, from 27 July 1794 until 26 October 1795, was a time of nationwide exercises in revenge, popular revolts, and an utter lack of political unity, despite all political rhetoric that sought to suggest otherwise. ${ }^{24}$ Nonetheless, read in combination with other statements of the period, Lindet's report points to a number of broader reflections on what leading Thermidorian politicians thought post-terror citizenship should look like.

First, although Lindet made clear that the crimes and the 'abuses' of the past few years could not be denied, he remained deliberately vague as to what exactly these crimes and abuses consisted of. What distinguished acts of terror from noble revolutionary acts was a vexed question he did not want to burn his fingers on. The bloody struggle against 'counterrevolutionary forces' could not simply be condemned without the risk of calling into the question the cause of the revolution en toto. Instead he argued that most individuals had simply made 'mistakes', 'errors of insight' committed from the noble conviction that one was serving the fatherland. Individualizing responsibility for the reign of Terror in such a way enabled Lindet and many Thermidorians with him to integrate the experience of the Terror - and, importantly, the heroic emergence from the Terror - within the larger revolutionary drama. Thus, the 9th of Thermidor was juxtaposed in the report with the journées of the 14th of July (the fall of the Bastille) and the and of August (the fall of the monarchy). 'The journée of 9 Thermidor', Lindet stated, 'will teach posterity that with this epoch the French nation has proceeded through all stages of its revolution'. ${ }^{25}$ The Terror did not signify the failure of the revolution, but a necessary, if lamentable, phase.

In addition, attributing the Terror to mistakes of certain individuals implied that the people as a collective did not bear responsibility. On the contrary, 'We will not regard the errors of some citizens as a derailment of the people. Some citizens were captivated; but the people as a whole, attached to principles and the national representation, have condemned Robespierre and his accomplices'. By stressing the 'the wise, great, and sublime conduct of the people' (the people and its representatives were often mentioned in one

24 M. Vovelle (ed.), Le tournant de l'an III. Réaction et Terreur blanche dans la France révolutionnaire (Paris: Éditions du CTHS, 1997).

25 Lindet, Rapport fait à la Convention nationale, p. 609 . 
breath), Lindet sought to bolster the legitimacy and authority of the National Convention. After all, as the national symbolic embodiment of the people, the representatives had been 'sufficiently great, sufficiently strong to strike the traitors. ${ }^{26}$ The representatives of the National Convention (the majority of whom actually served during the Jacobin Terror), then, should 'tighten and draw closer the resources of government' so as to 'singlehandedly guide revolutionary currents'. ${ }^{27}$ Lindet's report, thus, articulated the effort and ongoing preoccupation of Thermidorian and Directorial France to re-establish a strong centralized government - and its direct relation with the people. This direct relationship implied the absence of the mediation or interference of popular associations.

For the emerging Thermidorian centre, the individualization of responsibility for the deeds of Terror was a way to purify key political concepts of the revolutionary era - 'people', 'citizens', even the very notion of 'revolution' itself - and detach them from the memory and experience of the reign of Terror. This attempt to save revolutionary language from being permanently stained by the Terror applied particularly to the concept of citizen. On the day of Robespierre's fall, Bertrand Barère, a prominent Montagnard, member of the Committee of Public Safety, and one of the leading conspirators against Robespierre, repeatedly used the term 'good citizens' to refer to those who in his eyes were unduly held in detention under the reign of Terror. ${ }^{28}$ Other representatives too began to employ the notion of the good citizen to allow victims, suspects, and those who were relieved that the Robespierrist regime had to come to an end, to rally behind what was still a motley of moderates and ex-Montagnards cautiously seeking to dismantle the institutions of the Terror.

On August 19, 1794 (2 Fructidor II), Tallien, in response to a number of voices in the National Convention that called for 'the most severe justice' to be applied to aristocrats, argued that the distinctions between 'aristocrats', 'moderates', and 'patriots' made no sense anymore: 'In the republic I no longer recognize classes', Tallien orated in a speech that would be frequently interrupted by applause. 'I only see good and bad citizens. What does it matter to me that a man is born a noble if he behaves properly? What does a man's plebeian status tell me if he is a scoundrel?'29 Barère's and Tallien's terminology of 'good citizen'

\footnotetext{
26 Lindet, Rapport fait à la Convention nationale, p. 609 .

27 Ibid., p. 616.

28 Réimpression Gazette nationale ou le moniteur universel 21, no. 312, 12 thermidor, l'an 2 (July 30, 1794), Séance 9 Thermidor, pp. 337-348, at p. 340.

29 Réimpression Gazette national ou le moniteur universel 21, no. 333, 3 fructidor, l'an 2 (20 August 1794), Séance du 2 fructidor (19 August), 529-536, at p. 534.
} 
and 'bad citizen' would be reiterated over and over again during the Thermidorian period and after.

In a report presented to the National Convention in early September 1794 on the principles of revolutionary government, for example, former Girondin, friend and translator of Thomas Paine, François Lanthenas suggested that the 'force' of revolutionary government 'increases a hundred fold by the everlasting indestructible union of good citizens, and by the simplest purge of the bad [citizens]. ${ }^{30}$ Both ex-Montagnards, former Girondins, and those from the Plain (unaffiliated with either faction) appropriated the term 'good' citizen as a linguistic and rhetorical vehicle to bring about national unity.

That this terminology would be eagerly picked up can be explained by the need they and others felt to draw new demarcation lines between friend and enemy. In the months following the fall of Robespierre, the perpetrators of the Terror would be branded with a variety of epithets: conspirators, counterrevolutionaries, scoundrels, tigers, blood drinkers, barbarians, cannibals, vandals, and eventually Jacobins. But there was no plausible claim to be made that the Terror was executed by enemy number one during the early years of the revolution: the aristocracy. After the abolishment of feudalism, there was conceptually only one class left, that of citizens. But if a portion of that very class of citizens was guilty of the most hideous crimes, new moral and political categorizations were required. The terminology of 'good' and 'bad' citizens provided this categorization.

In his report, Robert Lindet also deliberately employed this terminology. He impressed upon his fellow representatives that they had to be inclusive and exclusive at the same time: 'You founded a republic not only for yourself, but for all Frenchmen who wish to be free; you are not permitted to exclude anyone but the bad citizen'.31 Like Tallien, he called upon his citizens not to judge their fellow citizens by looking back to their former profession or by tracing family origins, for 'The bad citizen is known through his actions'. The good citizen, in contrast, appeared in Lindet's recommendations to the National Convention on how to deal effectively with internal rebels (the Vendee in particular). Twice he stressed that it were the 'good citizens' who must be reassured of the government's military strength and 'good citizens' who must be protected against the rebels. ${ }^{32}$ The good citizen

$30 \quad$ Réimpression Gazette National ou le moniteur universel 21, no. 351, 21 Fructidor II, (7 September 1794), Séance du 19 Fructidor (5 September), pp. 682-688, at p. 688.

31 Lindet, Rapport fait à la Convention nationale, p. 611.

32 Lindet, Rapport fait à la Convention nationale, p. 612. Réimpression Gazette Nationale 22, no, 3, 3 vendémiaire, l'an 3 (24 September 1794), pp. 21-22. 
was, thus, not only a future-oriented concept forged with a view to reunite Frenchmen from different backgrounds and histories. It would be put forth as the pinnacle of an alternative to the Jacobin republic, emphasising national unity, order, security and prosperity.

The famine of the winter of 1795 , the continued political violence, the flagrant violations of the constitution (the two-thirds degree in particular), the purges of legislators, the (First) White Terror in southern France, all exposed the discrepancy between rhetoric and reality. ${ }^{33}$ While the Thermidorian centre sought to reinvent the notion of citizenship in the name of national unification, this discrepancy rendered the post-Terror concept of citizen partial and deprived it of the broadly based legitimacy they hoped for.

The unresolved, crucial, and contested issue was not only what this 'good citizen' should look like. It was also to be determined who were or had been 'bad' citizens and what kind of justice should be applied to them. ${ }^{34}$ Within only a few months after Robespierre's fall, step by step the blame was put on the shoulders of the Jacobins. In early October, the National Convention backed away from the language of a vaguely defined collective responsibility and, in the words of Lindet, individuals' 'errors, dangers, and misfortunes', and committed itself to prosecute criminals. The trial of Jean-Baptise Carrier, a notorious 'representative on mission' alleged to be responsible for mass drownings in the river Loire in Nantes, was widely reported and commented upon in the press. ${ }^{35}$ The effect of Carrier's trial was not only that it exposed the horrors of the Terror but also that it laid bare the wider context of the responsibility of government officials, and even of the revolutionary government of 1793-94 itself. Finally, prominent politicians such as Tallien and Fréron publicly turned against the Jacobins and sans-culottes, backed by an increasingly hostile Thermidorian press and vengeful militias of dandyish jeunesse dorée eager to close down on the Jacobin clubs. The 'bad' citizen was increasingly identified as the Jacobin citizen. It was in this context that the post-Terror good citizen was detached from the environment of popular societies.

33 On the purges of legislators after Thermidor, see M. Harder, 'A Second Terror: The Purges of French Revolutionary Legislators after Thermidor', French Historical Studies 38 (2015), pp. 33-6o.

34 Brown, 'Robespierre's Tail'.

35 'Representatives on mission' were envoys appointed by the National Convention to act as supervisors of local authorities. Some representatives, such as Carrier, became known for their acts of brutal repression and terror. 
The sustained attacks on the Jacobins, in both the National Convention, the press, and on the streets, created the circumstances in which the already weakened network of Jacobin clubs was being dismantled by decree. On 16 October, 1794 (25 Vendémiaire III), a report was presented to the National Convention on the 'policing' of popular societies. The National Convention's debate over the report is particularly insightful as we can find here a sustained effort by a number of centrist Thermidorians to detach the citizen from the highly politicized environment of political clubs. In doing so, they articulated an important aspect of what they thought the post-Terror good citizenship entailed. The report contained a proposal to ban all 'affiliations, aggregations, [and] correspondences between popular societies' as 'subversive to revolutionary government'. It escaped no one that what the report really targeted was the most famous of popular societies, the Jacobin Club.

Upon the presentation of the proposed decree in mid-October 1794, representative Antoine Claire Thibaudeau straightaway pointed to the ambivalent history and nature of popular societies. No one would deny, he thought, that popular societies should refrain from 'competing' with formally instituted government bodies. Yet, the individual members who made up the societies 'have inherent rights in their quality as citizens' to form societies, rights 'that are beyond the power of government to take away'. ${ }^{36}$ Lejeune backed Thibaudeau and invoked the right, guaranteed by the Declaration of the Rights of Man and Citizen, of freedom of thought and expression, either through the press 'or in any other manner'. He went on to remind his fellow representatives of the allimportant function popular societies had fulfilled, namely of disseminating amongst the people 'social virtues and the hate against tyranny'. ${ }^{37}$ As such popular societies had played a vital part in the illustrious unfolding of the early revolution. The former Jacobin Joseph Augustin Crassous concurred. 'Sprung in the very bosom of the revolution', popular societies 'became one of her strongest pillars'. And it was because of their influence that 'the public spirit was elevated to such a level of energy' that they had become 'safeguards of liberty'.38 Among a significant number of representatives, popular societies, including the Jacobin societies, still enjoyed a venerable reputation although they also agreed that the Jacobin Club had transgressed its original purpose and boundaries.

36 AP 99, Séance du 25 vendémiaire an III (jeudi 16 octobre 1794), p. 204.

37 Ibid., p. 207.

38 Ibid., p. 212. 
Other representatives saw the debate over the proposed decree as an opportunity to frontally attack the internal and external workings of the Jacobin Clubs. Merlin de Thionville started out by arguing that without the assistance of the Jacobins, Robespierre and his accomplices would never have been able to dominate French politics (and as a prominent ex-Montagnard he could know). The societies put power in the hands of men 'placed outside the Convention'. He subsequently asked, 'What is representative government?' 'Is it not where representatives shape the public voice? If you admit that some citizens or societies are not subjected to laws and are able to rise against the national representation, then government is merely anarchic' ${ }^{39}$ This accusation of forming a parallel centre of political power next to the National Convention was elaborated by others in a number of ways. One argumentative strategy was to analyse the popular societies in terms of a new form of corporatism or as resembling the constituted bodies of the ancien régime. The future Director Jean-François Reubell, for instance, acknowledged citizens' rights to communicate among each other, but objected to 'men who wish to put themselves above the law, men who, communicating amongst each other as citizens, wish to be more than other citizens, wish to communicate like a corporation'. According to Reubell, it was 'the abuse of these corporations' that had caused 'all calamities'. ${ }^{40}$ François Louis Bourdon compared popular societies with a convent of 'friars' where its members are selected 'amongst each other'. Popular societies smacked of aristocratic, constituted bodies challenging centralized government, he argued. 'Aristocracy starts where a group of men, through their correspondence with other groups, makes other opinions triumph than those of the national representation'. The contrast with the National Convention, Bourdon suggested, could not be more obvious. 'We are a democratic republic; our government is representative; it is composed of men who are chosen by the people; but what are popular societies? An association of men who elect themselves. ${ }^{41}$ Jacques-Alexis Thuriot complemented Bourdon's argument by simply saying that 'the people does not reside in the societies. Sovereignty resides in the universality of the nation.' 42

39 Réimpression Gazette Nationale 22, no. 28, 28 vendémiaire, l'an 3 (Octobre 19, 1794), Séance du 25 vendémiaire (16 octobre 1794), p. 256. The Archives Parlementaires does not contain this speech of Merlin de Thionville.

$40 \quad A P$ 99, Séance du 25 vendémiaire an III (jeudi 16 octobre 1794), p. 208.

41 Ibid., p. 210.

42 Ibid., p. 214. 
The fundamental objection against popular societies was not only that they presented a threat to the 'unrivalled centre of authority', as one representative put it, or established an alternative 'centre of opinion' as another had it. Political societies, and the Jacobin Club in particular, were accused of cooking up opinions that neither citizens nor their representatives would ever come to entertain if they would be left reasoning on their own. That is to say, if they would form opinions independently and on the basis of their individual mental capabilities and judgment. Popular societies, in short, were seen as having a malignant influence on public opinion formation. They will 'force the people and its delegates', as Merlin de Thionville put it, 'to have opinions which will never enter their intention'. A similar dismissive analysis was put forward by Pierre-Louis Roederer in an anonymous pamphlet on 'Popular societies' published on 20 November 1794. Roederer concurred that it is an 'inalienable right of man to assemble in popular societies'. But the essence of such societies of 'friendship and instruction' is contemplative, not political. They should be prohibited, as societies do not have the freedom of opinion as individuals do, to make 'interruptions on political matters'. For

A collective opinion exercises on individual opinions a kind of authority that is contrary to the formation of public opinion, which can only emerge spontaneously in the bosom of liberty and wisdom; opinions of a brotherhood, a corporation, a sect, a party, are substituted for the opinion of the people, which, revealed by herself, is solely attuned to the general interest. 43

Popular societies stand in the way of what Roederer called 'impartiality', which could only be achieved by leaving individual citizens to reason on their own.

Supporters of popular societies feared that the attack on popular societies as unlawful 'corporations' deprived citizens of a vital platform of public organization, civic engagement and political participation. During the debate about the report, representative Joseph-Nicolas Barbeau du Barran expressed this fear most sharply: 'The proposed measure is apolitical'. What is needed, he went on, is that representatives 'multiply and strengthen the very ties of union and fraternity that exist amongst citizens', instead of weakening them. After all, 'We wish to form good citizens; we don't condemn then into isolation', for

43 P.L. Roederer, 'Des sociétés populaires', in: CEuvres du comte P.L. Roederer, 8 vols. (Paris: Firmin-Didot frères, 1853-1859), pp. 17-22, at p. 21. This piece was originally published in Le républicain of November $20,1794$. 
isolation is nothing less than the 'lethal poison of republican energy' 44 The arguments in defence of the popular societies by Barbeau du Barran and others could not turn the tide against them. The decree was passed with only a few small amendments. Less than a month later, on 11 November (21 Brumaire), the Jacobin Club was closed, although the closure of all popular societies was only ordered in late August 1795 .

The model of the citizen detached from popular societies and standing in an unmediated relation to the national representation became a mainstay of centrist Thermidorian political thought. In his famous speech delivered at the presentation of the constitution proposed by the Commission of Eleven on 23 June 1795, Boissy d'Anglas echoed the thrust of argumentation deployed against the popular societies in the debate of October 1794. He called the Jacobin club the 'most formidable and most dangerous of all political associations.' 'We believe that no society can be called popular without infringing on the right of the people as a whole. There are no popular assemblies but the legally instituted parts of the great assembly of the entire people. For a society to be popular, it is necessary that each citizen is called to it'. There is only one popular society with one national representation, and it is through this relationship alone that 'he is citizen'. 45

Although it is important, as Baczko suggested, to note the continuity and persistence of the 'unitary conception of the political arena' as articulated in both the earlier stages of the revolution and by centrist Thermidorians, the experience of, and reflection on, the Terror added extra dimensions to the evaluation of the phenomenon of popular societies. The popular societies, and the Jacobin clubs in particular, became identified with, and perceived as the embodiment of, faction and party spirit. In 1791, the critical analysis of popular societies as intermediary bodies had been largely theoretical. ${ }^{46}$ After 9 Thermidor, critics of popular societies drew on the experience of $1792-1794$ as an empirical argumentative basis. Because of its alliance with the Parisian sansculotte movement, faction as represented by the Jacobin Club became intimately bound up with the direct involvement of the masses in politics, the danger of political passions and fanaticism, and the interaction between demagoguery leadership and mob dynamic. The Terror, it was now argued, was caused by a combination of an explosion of unchecked dangerous passions,

\footnotetext{
44 AP 99, Séance du 25 vendémiaire an III (jeudi 16 octobre 1794), p. 213.

45 Boissy d'Anglas, Projet de constitution pour la République français, et discours préliminaire prononcé par Boissy d'Anglas au nom de la Commission des onze (Paris: Imprimerie de la république, 1795), pp. 12, 80.

46 Rosanvallon, The Demands of Liberty, pp. 16-21.
} 
the vicious exploitation of ideas by demagogic leaders, ferocious party spirit, and a specifically lethal interaction between the uneducated mass and its leadership.

These allegations became a mainstay argument against popular societies throughout the period of the Directory of $1795^{-1799}$. One example is the book De l'influence des passions sur le bonheur des individus et des nations (On the Influence of the Passions on the Happiness of Individuals and Nations) by Anne Louise Germaine, Baronne de Staël-Holstein - Madame de Staël. One of her Thermidorian writings that is hardly ever referred to by historians of political thought, it offered a dissection of the dynamics of Terror, mob behaviour, and political fanaticism as displayed during the Jacobin Republic. ${ }^{47}$ Written from 1793 onwards and finalized in Coppet, Switzerland, De l'influence des passions was one of only two of De Staël's Thermidorian political writings that was actually published. It was reviewed by Roederer in Journal d'économie publique; a second edition appeared in 1797. It was furthermore translated into English in 1798 , and received many positive reviews in the German press. ${ }^{48}$ Although De Staël had already made her entrance into the Thermidorian public sphere with a pamphlet published in 1795 , and was a victim of attacks by the republican press and politicians accusing her of being an émigré advocate of the royalist cause, it was De l'influence des passions that brought her fame, not only in France but throughout Europe.

47 Between 1794 and 1798, De Staël wrote four essays that dealt, in various ways, with the experience of the Jacobin regime and the Terror, and, moreover, suggested theoretically informed solutions to prevent the French Republic from falling back into what she considered the popular anarchy of the Jacobin era: Réflexions sur la paix adressées à M. Pitt et aux Français (Reflections on Peace addressed to M. Pitt and the French) was written in October-November 1794. Réflexions sur la paix intérieure (Reflections on internal Peace, 1795), written between late June and September 1795. De l'influence des passions sur le bonheur des individus et des nations (On the Influence of the Passions on the Happiness of Individuals and Nations, 1796). Lastly, Des circonstances actuelles qui peuvent terminer la révolution et des principes qui doivent fonder la république en France (On the current Circumstances which can end the Revolution and on the Principles on which the Republic in France should be established), written in the (long) aftermath of the anti-royalist coup d'état of 18 Fructidor V (4 September 1797), most likely between May and October 1798. Although only published posthumously in 1979, it was written in close collaboration with Benjamin Constant, whose remarks were scattered through the original manuscript.

48 K., Margerison, P.L. Roederer: Political Thought and Practice during the French Revolution (Philadelphia, PA: Transactions of the American Philosophical Society, 1983), p. 111. A second edition came out in Paris in 1797. See, F. Lotterie, 'Introduction', in: Madame de Staël, CEuvres Complètes I, 1, ed. F. Lotterie (Paris: Honoré Champion Éditeur, 2008), pp. 124-127. 
While the work is a reconsideration of the role of human passions in public affairs and personal life, and more particularly an enquiry into the question which passions ought to be encouraged and which restrained, it also addressed the relationship between popular societies and faction. Assembled in a 'body', De Staël explained, multitudes tend to be governed by suspicion and are easily carried away by 'exaggerated promises', since the germ of 'fermentation', of turmoil, is always latently present in a large gathering. ${ }^{49}$ Masses, in short, are inconstant, 'moveable'. Since 'assembled men communicate only by means of this electricity, and contribute nothing but their sentiments [...] it is not the wisdom of anyone, but the general impulse that produces a result'.50 Echoing the arguments of the Convention's debate over the restraint of popular societies in October 1794, De Staël argued that in revolutionary times people absorbed by political societies lose their individuality, their conscious agency, indeed their very power to influence events and shape the future, because they are dragged forth by the maelstrom of passion and political power play. She argued that this dynamic of mob rule and demagogical leadership destroys the balancing influence of public opinion. The Montagnard political culture of fear and conspiracy, branding anyone remotely critical as counterrevolutionary or simply the enemy, suffocates public reason. In such a climate

opinion does not exist anymore; the people command instead of judge; playing an active role in all events, they take sides for or against one or another man. In a nation, there are only combatants left; the impartial power called the public is nowhere to be found. ${ }^{51}$

This spirit of faction and party 'seizes you like a kind of dictatorship that silences altogether the authority of spirit, reason, and sentiment'.52

A similar analysis was put forth in 1797 by Pierre-Charles-Louis Baudin des Ardennes, national representative, member of the constitutional Committee of Eleven, and member of the National Institute's Class of Moral and Political Sciences. 'The idea that most commonly invokes the word faction, taken in its political sense, is that of an association, which, for the interest of one or several individuals, aims at bringing down established government'. Going beyond the revolutionary inability to accommodate political pluralism in the political system, Baudin des Ardennes related factious popular societies explicitly to

49 Madame de Staël, De l'influence des passions, p. 221.

$50 \quad$ Ibid., p. 179 .

51 Ibid.

52 Ibid., pp. 223, 229. 
enthusiasm, political utopianism, and finally, to the crimes of the Terror. Drawing on the history and memory of the Terror, Baudin explained that faction is governed by the 'spirit of unsteadiness and disorder' mixed with a 'universal and salutary impulse aimed at regenerating everything'. It 'appeals to little attentive spirits through the impetuosity of a zeal which appears to raise the energy of other citizens' and 'raises crime to system, heinousness to doctrine. ${ }^{53}$

The Thermidorian centre, both in and outside the National Convention, thus dismantled the popular society as the main platform for civic spiritedness. The ideal of citizenship they articulated was that of an independent, reflective individual, free from factional forces and the inconstancy of passionate politics. The model of citizenship they ended up with was at the same time that of a harmless, isolated, citizen who should redirect his energy and purpose, away from politics.

This model did not go unchallenged. As Isser Woloch and Bernard Gainot have shown, during $1795^{-1799}$ a severely weakened but persistent neo-Jacobin current remained alive and committed to a more democratic form of republicanism and participatory citizenship. This persuasion was publicly articulated in journals such as Journal des hommes libres and embodied in revived clubs, both in Paris and the provinces. ${ }^{54}$ After the anti-royalist coup d'état of 18 Fructidor Year V (September 4, 1797) carried out by the three republican Directors Barras, Reubell, and La Révellière-Lépeaux and backed by the military, the resurgence of clubs was tolerated to some extent. The neo-Jacobins of $1795^{-1799}$ did not opt for a class war and the redistribution of wealth as Babeuvist egalitarians did. Instead, they firmly defended the right of private property, while emphasizing everyone's 'right of subsistence'. And at least for the time being, they accepted the Thermidorian constitution of 1795 , as they perceived the biggest threat to be coming from the right. Unlike centrist Thermidorians, they viewed popular societies as a constitutive element of a healthy 'representative government'. As one pamphlet put it: 'One might say that representative government is the natural domain of petitions, discussions, clubs, newspapers, civic banquets, political parties, and polemical disputes. Out of this turbulence wisdom emerges; from all these elements liberty is nurtured. ${ }^{55}$

53 P.-C.-L. Baudin des Ardennes, 'De l'esprit de faction considéré par rapport à son influence sur les différens gouvernemens', in Mémoires de l'institut national des sciences et arts pour l'an IV de la république (Paris: Baudouin, 1797), vol. 1, pp. 493-503, at pp. 495-496.

54 See also J.D. Popkin, 'Les journaux républicains, 1795-1799', Revue d'histoire moderne et contemporaine 31 (1984), pp. 143-157.

55 Français de Nantes, Coup d'CEil rapide sur les Moeurs, les lois, les contributions, les secours publics, les sociétés publiques... dans leur rapport avec le Gouvernement représentatif 
The neo-Jacobin revival that in late 1797 and early 1798 for a time seemed to develop into a genuine opposition, that is, within the constitutional framework of the republic, was, however, quickly snuffed out. On March 29, 1798, the National Convention decreed that a Jacobin party would essentially not be tolerated. With the anti-Jacobin purge of the 22 Floréal Year VI (May 11, 1798), and the subsequent closing down of the Jacobin press, ' $[\mathrm{t}]$ he momentum of the Jacobin resurgence was broken.5 ${ }^{56}$ One last time, in the Summer of ${ }^{1799}$, the neo-Jacobin movement flickered, as Jacobin newspapers again began to reappear and new clubs were formed. Late August and early September witnessed the French Revolution's final debate on popular societies. Jacobin representatives, proposing a law that would protect the rights of popular societies and leave them relatively unhindered, considered the 'droit de réunion et association' one of the pillars of citizenship in a republic. In their view, popular societies were platforms of public opinion formation, and checks on representative government. Representative government required active citizens who 'censure', 'applaud' and 'criticize' their representatives. In popular societies, 'with the assistance of conversation, [and] discussion', a citizen 'informs and educates himself; there, he becomes aware of the benefits of laws and administrative acts'. ${ }^{57}$ The anti-Jacobin counter proposals were more numerous and much more repressive. One telling response is that of the physician and philosopher Pierre-Jean-George Cabanis, member of the Council of Five Hundred and the French National Institute, and future conspirator in Bonaparte's coup in November 1799. Cabanis recalled that political societies had been 'the cause or instrument of the greatest disorder, the cruellest calamities' and 'the most powerful weapon against order and the rule of law', ${ }^{58}$ His reasoning was based on 'fatal experience', echoing centrist Thermidorians that popular societies tend to be overtaken by ambitious demagogues and 'conspirators'. Discussions there only sowed 'distrust and division'.59 Popular societies, he argued, challenge public authorities, exercise 'illegal' influence and thereby transgress the sovereignty of the people who have never elected them. Cabanis defended 'the

(Grenoble: Imprim. près la Salle, pluviôse an vi [February, 1798]), as cited in: Woloch, The Jacobin Legacy, p. 159.

$5^{6} \quad$ Woloch, The Jacobin Legacy, p. 348.

57 J. Guinard, Opinion de Guinard (de la Lys), sur la répartition de la contribution foncière de l'an 8. Conseil des cinq-cents, séance du 16 vendémiaire an 8, as cited in: C. Peyrard, 'Les débats sur le droit d'association et de réunion sous le Directoire', Annales historiques de la Révolution française 297 (1994), pp. 463-478, at p. 476.

58 P.J.G. Cabanis, Opinion de Cabanis, sur les réunions s'occupant d'objets politiques (Paris: Baudouin, Imprimeur du Corps Législatif, n.d.), pp. 1-2.

59 Opinion de Cabanis, pp. 2-3. 
calm and industrious' citizen who must not be terrified, 'the frail momentum of industrial or commercial enterprise' must not be 'suffocated' by popular societies bringing chaos and disorder. ${ }^{60}$ Like his conservative colleagues then, Cabanis proposed severe restrictions on 'meetings of citizens'. In the end, the legislature did not agree on a new law. But several months later, in November 1799, Napoleon Bonaparte's seizure of power wiped out Jacobin clubism, and with it, civic activism. French subjecthood under Bonaparte was a continuation of the model of isolated, depoliticized citizenship advocated by centrist Thermidorians and conservatives under the Directory.

\section{What Is a Good Citizen? Redefining Civic Virtues}

As we have seen, the identification of bad citizens during the Terror as bloodthirsty criminals at worst and deluded enthusiasts at best, was increasingly related to the internal and external workings of the Jacobin clubs, up until 1799 . In redefining good citizenship, the 'bad' citizen of the Jacobin Terror became the negative other. But if the citizen should turn away from politicized clubs, faction, and avert inflamed involvement in politics, what alternative model of citizenship was offered instead? In other words, what kinds of more substantial visions on the good citizen developed over the course of post-Thermidor 1794 and early 1795 ? And who were deemed qualified to become full-fledged citizens?

The post-Terror model of citizenship was anything but settled, but a general picture can be formed by piecing together fragments from speeches and public statements made by the Thermidorian centre that would appear throughout Thermidor and into the Directory. Again, Lindet's report contains some first constitutive elements. Absolutely central to the report is the 'useful and industrious citizen', which is 'known by his sacrifices, by his multiple hardships, by his services, [and] by his active and industrious life. ${ }^{61}$

The model of the industrious citizen was of course anything but new. It had been one of the centre pieces of early revolutionary discourse and a powerful rhetorical symbol placed in opposition to the idle and unproductive aristocrat. Indeed, the most important pamphlet of the French Revolution, Sieyès's What is the Third Estate, defined the nation as productive, industrious citizens. Because they did not contribute to society, idle aristocrats were branded as foreign, in both an economic and political sense. Useful and industrious citizens, Sieyès

6o Opinion de Cabanis, p. 8 .

61 Lindet, Rapport, pp. 612, 616. 
argued, constituted the political community, the locus of national sovereignty. Economic utility was a condition for the exercise of popular sovereignty. ${ }^{62}$

What distinguishes post-Terror expressions of the ideal of the industrious citizen was that they were more explicitly set alongside, and in opposition to, the politically active citizen. Certainly, Sieyès's model of representative government, predicated on a complex modern society, was not particularly well known for its robust (republican) ideals of politically active citizenship in the first place. But after the Terror, there was a sense that the Terror had proven just that: that an exaggerated public spiritedness among broad layers of the population was not only dangerous, but also impaired the economic well-being of society. As Lindet's report urged: 'The voice of France now recalls to their labours and their professions a great number of citizens who had suspended them to fill public functions'. This call was addressed to 'proprietors and farmers', but equally to 'sages and artists', who, according to the report, had been persecuted and oppressed under the regime of Robespierre. ${ }^{63}$

It is no grave exaggeration to say that the attempts made by Thermidorians to refocus civic energy on labour was a victory of the language of political economy over classical republicanism. An elaborate and profound expression of a more socioeconomic interpretation of citizenship, partly articulated in reaction to militant Jacobin patriotism and the growing influence of the Parisian populace, can be found in a series of lectures delivered by the political economist and journalist Pierre-Louis Roederer at the Lycée between January and June 1793 (before the 'Great Terror' of 1794 ) ${ }^{64}$ In his lectures entitled Cours d'organisation sociale, Roederer had offered an elaborate defence of a model of citizenship that he thought was appropriate for a large modern republic like France.

His vision entailed, first, a critique of the économiste or physiocratic exclusive focus on agricultural production and the corresponding ideal of the landed property-owner as the foundation of wealth, and hence, society. Second, it was also a rejection of the Montagnard ethics of self-sacrifice steeped in ancient republican ideals, an ethics Roederer thought was reanimated in the works of Rousseau and Mably, and subsequently adopted by Robespierre and

62 See Sewell, A Rhetoric of Bourgeois Revolution, pp. 78-85, 145-152; Sonenscher, Before the Deluge, pp. 259-266.

63 Lindet, Rapport, p. 610-611 (italics are mine).

64 For commentary, see R. Scurr, 'Social Equality in Pierre-Louis Roederer's Interpretation of the Modern Republic, 1793', History of European Ideas 26 (2000), pp. 105-126; idem, 'PierreLouis Roederer and the Debate on the Forms of Government in Revolutionary France', Political Studies $5^{2}$ (2004), pp. 251-268; Sonenscher, Before the Deluge, pp. 322-334; Whatmore, Republicanism and the French Revolution, pp. 98-104. 
Marat. Both conceptions, Roederer maintained, were inappropriate for a modern, commercial republic. According to Roederer, whereas, on the one hand, the Physiocrats had a flawed conception of social organization and hierarchy, favouring large land-owners at the expense of (landless) agricultural workers, manufacturers, artisans, and industrialists, the Montagnards, on the other hand, seemed antithetical to the reality of division of labour and softened manners that characterized modern commercial societies. Instead of radical changes in the form of government, a return to a classical-republican public ethics, ceremonies and festivities, in his theory of 'social organization' Roederer singled out the institution of labour as the primary institution: 'It is this allencompassing institution of labour in a great nation that I call the great and true principle of [...] good moeurs'.65 As men were in Roederer's view fundamentally self-interested, he thought that labour can motivate people to acquire riches, and, thus, contribute to the general welfare. Yet, labour had a much broader social and moral significance in Roederer's vision. Labour furthers the cultivation of talents, 'domestic' as well as 'social' virtues, and establishes enduring relations between the rich and the poor. As such labour is the great 'maintainer of order'.

Commenting on the tumultuous developments he had witnessed in 1792 and early 1793 , Roederer maintained that when a people emerges from 'long and continuous convulsions' and is agitated by 'irregular movements', the only way to bring citizens back under the rule of law is by 'putting them back to work, which means to let them stay away from factions [and] popular assemblies', and make their way again 'into the workshops of agriculture, arts, and trade'.66 An almost identical point was made by Lindet who deemed it vital that commerce would be reanimated. The more specific point Lindet's report wanted to convey was that citizens should again feel confident to engage in commercial activities, private entrepreneurship, as well as the arts, sciences, and manufacture. Lindet urged his fellow representatives: 'Declare solemnly that every citizen who employs his days usefully in agriculture, science, arts, or commerce, who elevates or supports factories, manufactures, can neither be hindered nor be treated as a suspect' ${ }^{\prime} 7$ The report explained that this confidence could be restored by guaranteeing citizens 'individual liberty' and equality before the law. The appearance of the industrious citizen in Thermidorian political discourse, thus, went hand in hand with a broadly shared desire for

65 P.L. Roederer, 'Cours d'organisation sociale', in: CEuvres du comte P.L. Roederer, vol. 8, pp. 129-305, at p. 266.

66 Roederer, 'Cours d'organisation sociale', p. 266.

67 Lindet, Rapport, p. 612. 
economic recovery. The majority view was that this could be achieved by adopting laissez faire economic policies and by stimulating (foreign) commerce and industry. Rather than political engagement and civic virtue, economic liberty and the legal protection of property were to characterize post-Terror conceptions of the 'good citizen'. ${ }^{6}$

The figure of the industrious good citizen would reappear in many public statements and speeches of representatives in the aftermath of 9 Thermidor. On 9 October (18 Vendémiaire) a public address was presented to the French people in the name of the committees of Public Safety, General Security, and Legislation (which made it to American newspapers). ${ }^{69}$ It was ordered by the National Convention by a decree agreed upon a week earlier which demanded clarity on 'the principles around which the friends of liberty are to be reunited'. Like Lindet's report, it called upon the French to 'value [...] industrious and modest men, these good and pure beings'. The Convention's address is in another respect noteworthy. It was at pains to make sure that the industrious and modest citizen practices 'republican virtues', but, 'without ostentation.'70 'The warrior virtues give rise to the hero', it went on, 'the domestic virtues form the citizen', and these domestic virtues 'maintain and reinforce an invincible attachment to republican principles. ${ }^{71}$ As their statements demonstrate, these Thermidorian politicians sought to uphold their republican credentials, while simultaneously articulating elements of a post-revolutionary vision of good citizenship centred on the domestic sphere and industry. In the debate that took place after the presentation of the address, Tallien wholeheartedly confirmed the report's message. Closely associated with Roederer at that time, Tallien echoed the thrust of the latter's lectures, stating that that ' $[\mathrm{g}]$ ood citizens are useful men, industrious farmers, robust artisans, zealous defenders of the fatherland. ${ }^{72}$ Representative François-Louis Bourdon from Oise agreed and commented approvingly that the address 'can produce an excellent effect on the spirit of good citizens.' ${ }^{73}$

68 On the centrality of the legal defence of property under the Directory, see F. Furet and D. Richet, La Révolution française, 2 vols. (Paris: Hachette, 1965-66), Ch. 12.

69 The Daily Advertiser (New York, New York), December 15, 1794.

$70 \quad$ Réimpression Gazette nationale ou le moniteur universel 22, no. 21, 21 vendémiaire, l'an 3 (12 octobre 1794), p. 201.

71 Ibid., p. 201.

72 Ibid., p. 202. At the time, Roederer wrote several speeches for Tallien. See Margerison, P.-L. Roederer: Political Thought and Practice During the French Revolution, p. 114.

73 Réimpression Gazette nationale ou le moniteur universel 22, no. 21, 21 vendémiaire, l'an 3 (12 octobre 1794), p. 201. 
These arguments for a shift from political activism to labour, as expressed by Roederer, Tallien and others, became a mainstay of Thermidorian conceptions of citizenship. The issue was poignantly addressed in Boissy d'Anglas's speech for the constitution proposed by the Commission of Eleven: Boissy made clear that 'to make France a country in continual assembly was to deprive agriculture of those men who should attend to it with assiduity; it was to deprive commerce and the workshops of industry of those men who would better serve the country with their diligence than by useless speeches and superficial discussions. ${ }^{74}$ Outside the Convention, prominent members of the French National Institute, such as Jean-Baptiste Say and Pierre Cabanis, as well as many others, would in their writings reiterate the centrality of labour as the 'maintainer of order' and the kernel of citizenship. ${ }^{75}$ The post-Terror ideal of the industrious citizens implied a turn away from public service and political participation as the main platform of citizen activity.

\section{Narrowing Down Political Citizenship}

The debates and many publications surrounding the draft constitution of 1795, as well as the final version of the constitution that was accepted in August, contain important further indications of the ways in which the scope of citizenship was limited. During the winter and spring of 1795, many centrerepublican and constitutional royalist Thermidorians began to expand their analysis, in writing and speech, of what had caused the reign of Terror, and consequently, on what should be done to prevent it from happening again. Instead of attributing the Terror simply to Robespierre and his accomplices, or primarily to the infernal workings of Jacobin clubs, their focus shifted: toward the constitution of 1793, and more generally, toward the involvement in politics of what they considered to be the uneducated, or minimally educated, unpropertied masses.

In the spring of 1795, after an extremely harsh winter of food shortages and towering price levels, a 'Commission of Eleven' was charged with revising the Montagnard constitution of $1793 \cdot{ }^{76}$ They ended up devising an entirely new

74 Boissy, Projet de constitution pour la République français, et discours préliminaire, p. 25.

75 P.J.G. Cabanis, Rapports du physique et du moral de l'homme, 2 vols. (Paris: Caille et Ravier, 1815 [1802]), vol. 1, lxvii; J.-B. Say, Olbie (Paris: Deterville, 1800).

76 First a Commission of Seven was installed on 3 April, including Jean-Jacques Régis de Cambacérès, Jacques-Antoine Creuzé-Latouche, Denis-Toussaint Lesage d'Eure-et-Loir, Jean-Baptiste-Charles Mathieu, Phillipe-Antoine Merlin de Douai, Emmanuel-Joseph Sieyès, and Antoine-Claire Thibaudeau. On April 23 and May 4, the commission was 
constitution. The commission began its work under circumstances of severe crisis. Vengeful acts of slaughtering Jacobin perpetrators were committed in the south and south-east. Voices for a royalist restoration, both those of ultraroyalists, pre-1789 royalists, and the moderate constitutional royalists of 1791, cropped up, although they were unable to get a foothold. On April 1, 1795 (12 Germinal), an armed crowd invaded the Tuileries and the Convention. This scene was repeated on 20 May (1 Prairial), when an even larger armed crowd occupied the Convention demanding bread and the (Montagnard) Constitution of 1793, and famously presented the head of deputy Féraud on a pike to Boissy d'Anglas who then occupied the central chair as speaker of the Convention.

The political and symbolic significance of the Germinal-Prairial popular uprisings cannot be underestimated in order to understand the anti-populist mentality that came to overshadow the constitutional committee, its proposed constitution, and the Convention's constitutional debates over the summer of 1795. Above all, centrist politicians used the uprisings as a pretext to purge the National Convention of Montagnard strongholds.

Likewise, anti-Jacobin conventionnels latched onto the uprisings to push through a large-scale disarmament of remaining (urban) Jacobin militias. Both in the Convention then, as on the street, the radical left was dealt a final blow; the uprisings turned out to be its last convulsion. The ideal of the high-spirited armed citizen became irreversibly seen with suspicion. Finally, the invasion of the National Convention by a mass of predominantly lower-class militant Parisians deepened the centrist suspicion of popular and direct democracy. The crowd's rallying cry, 'bread and the constitution of 1793', only reinforced the centrist conviction that the republic desperately needed a new constitution that would put a strong curb on popular involvement. The question that gained prominence in the spring and summer of 1795 was, thus, not merely what kind of model of post-Terror citizenship should be adopted, but also who were eligible to be or become full-fledged citizens. In June-July 1795, moreover, an invasion of counter-revolutionary émigrés troops in southwest Brittany was defeated by the Republic's army, which enabled the Thermidorian centre to represent themselves as the moderate middle party.

expanded while some members were replaced, most notably Sieyès. The final Commission of Eleven was made up of: Creuzé-Latouche, Lesage, Thibaudeau, Francois-Antoine Boissy d'Anglas, Pierre-Claude-Francois Daunou, Louis-Marie La Révellière-Lepeaux, Jean-Baptiste Louvet, Pierre-Charles-Louis Baudin des Ardennes, Pierre-Toussaint Durand de Maillane, and Jean-Denis Lanjuinais. 
On 23 June, the Commission of Eleven offered a draft constitution to the National Convention, where it was debated over the summer, and accepted on August 22, 1795. The constitution of Year III, as it has come to be known, was formally implemented in late October and lasted until the coup of 18 Brumaire Year VIII (November 9, 1799). It would be the longest existing constitution of the French Revolution, but also the one that would be most often breached.

The diagnosis of prominent centrist Thermidorian politicians and publicists of the Jacobin version of popular democracy generally focused on three aspects: theoretically, it was claimed, the Jacobins had lost themselves in utopian metaphysical abstractions about equality; on a more sociological level it was argued that the derailment of popular democracy demonstrated that the propertyless class had no genuine interest in order and stability; and finally, it became widely held that mass popular politics was particularly dangerous because it seemed inextricably bound up with an excess of (political) 'fanaticism' or 'enthusiasm'. Popular democracy thus had resulted in a catastrophic experiment. Accordingly, their diagnosis led them to reformulate the ideal of equality, restating the central importance of owning property, and suggesting remedies to avoid outbursts of dangerous political sentiments and passions. I will deal with these issues in that particular order.

Although it is doubtful whether the 'Jacobin regime' can be said to have developed a unified and consistent political philosophy that proposed far-reaching programs aimed at a socio-economic levelling of society, it became a commonplace among centrist Thermidorians that the Jacobins had been collectively chasing philosophical fantasies of 'abstract' equality. ${ }^{77}$ In his speech that accompanied the presentation of the draft constitution of 1795 , Boissy d'Anglas, after recounting the 'tyranny' of the past few years, concluded that 'the illusionary principles of absolute democracy and unlimited equality are unquestionably the most formidable pitfalls for true liberty'.78 The constitutional commission was keen to put across their own reformulation of equality instead: 'Civil equality is indeed all that a rational man can demand. Absolute equality is a chimera'.79 Criticisms of the allegedly abstract, or even metaphysical, nature of the ideals of the French Revolution had of course from early on been put forth from various sides, catholic anti-philosophes and

77 See however, J.-P. Gross, Fair Shares for All:Jacobin Egalitarianism in Practice (Cambridge: Cambridge University Press, 1997). Generally, Jacobins were committed to the right of private property.

78 Boissy, Projet de constitution pour la République français, et discours préliminaire, p. 31.

79 Ibid. 
Burkean conservatives most prominent among them. ${ }^{80}$ But the rejection of philosophical utopian thinking by moderate Thermidorian republicans was different in kind. They still embraced 1789 as well as the idea of a declaration of rights, but ' $[\mathrm{t}]$ he liberty France wishes for is a liberty for every day, customary, practical', as representative Louis-Marie La Révellière-Lepeaux stated, so as not to 'get lost in metaphysical spheres'. ${ }^{81}$ It is in this respect also highly significant that, as representative Joseph-Jacques Defermon des Chapelières critically noted in early July, the proposed constitution did not contain the provision 'All men are born and remain free and equal in rights'. In fact, the declaration of the rights and duties of man and citizen did not contain any reference to natural rights, natural equality, or any reference to nature whatsoever. The first article of the declaration reads: "The rights of man in society are liberty, equality, security, property'. The third article addresses equality: 'Equality consists in this, that the law is the same for all. ${ }^{82}$

This language of civic equality was deployed as part of a larger Thermidorian agenda of national unity and conciliation, while explicitly reserving a conceptual space to advocate what in their eyes were legitimate forms of inequality or 'distinction'. Deputy and member of the Commission of Eleven JeanDenis Lanjuinais, for example, echoed the conciliatory inclusive Thermidorian language of citizenship by emphasizing that 'The French republic will have a regime of fraternity; she will guarantee all her citizens the full and complete enjoyment of their rights'. However, he hastened to add that the French Republic 'will endorse the distinctions which result essentially from virtue, talents, and the very necessity of assuring rights to all. ${ }^{83} \mathrm{~A}$ few months earlier, Boissy too had stressed that men, although 'everlastingly equal in rights', can never be equal in 'virtue, talents, and fortune'. ${ }^{4}$

The criticisms centrist Thermidorians filed against the Montagnard conception of equality comprised two aspects: first, that one should not strive after a socio-economic levelling of society; and second, that not everyone is equally equipped to participate in political decision-making processes, in particular

80 D. McMahon, Enemies of the Enlightenment: The French Counter-Enlightenment and the Making of Modernity (Oxford: Oxford University Press, 2001).

81 Réimpression Gazette nationale ou le moniteur universel 25, no. 292, 22 messidor, l'an 3, (10 juillet 1795), p. 170.

82 J. Godechot (eds.) Les constitutions de la France depuis 1789 (Paris: Garnier-Flammarion, 1970), p. 101 (emphasis mine).

83 Réimpression Gazette nationale ou le moniteur universel 25, no. 295, 25 messidor, l'an 3 (13 juillet 1795), Séance 21 messidor, p. 196.

84 Réimpression Gazette national ou le moniteur universel, no. 173, 23 ventôse, l'an III (13 Mars 1795), Séance du 21 ventôse (11 March), p. 66o. 
those people who do not own property. Equality of fortune, Boissy maintained, is 'a system of crime masked as patriotism' forged by 'sophists' such as Robespierre who merely had the intention of elevating themselves. Significantly, Boissy illustrated his attack on 'equality of fortune' by referring to François Chabot, a son of a simple cook who had made a career under the Jacobin regime and had become a notoriously ruthless representative on mission, confiscating estates of émigrés and imposing draconian war taxes on the aristocracy and wealthy moderates. Boissy suggested that Chabot's poverty and simple background went a long way to explain his 'system': 'This equality of fortune', Boissy concluded, 'is nothing else than the ruin of the social state and the return of the savage state'. 85

The Thermidorian alternative conceptions of civic equality, on the one hand, and moral, economic, and political distinction, on the other, were ultimately cemented in the constitution of Year III, although not without debate. It was decided that elections were to be organised in two stages. The first stage of voting took place in the so-called primary assemblies. They would elect the members of 'electoral assemblies', the electors. The requirements for citizenship and admittance to the primary assemblies were the following: a minimum age of 21, born and residing in France, registration in the civic register, and paying direct personal or property taxes (or a sum equivalent to three days of work), making the electoral base in fact wider than in the constitution of $1791 .{ }^{86}$ Power really resided, however, in the electoral assemblies, as they were exclusively authorized to elect the representatives for the Council of Five Hundred and the Council of Elders directly. For the electoral assemblies, qualifications were set much higher. Only citizens over 25 years old, owning property equivalent to one- to two hundred days of work (varying to local circumstances), were eligible to become electors.

The draft constitution of the Commission of Eleven originally proposed that electors in the electoral assemblies were to own 'landed' property. In his critical observations on the proposed constitution, the économiste and former Feuillant Pierre Samuel Dupont de Nemours agreed with this requirement, but argued that it should apply to citizenship in general, not only to electors. Dupont de Nemour's argumentation resembled that of Boissy d'Anglas. 'Robespierre and his accomplices' had waged a war against property owners in

85 Réimpression Gazette national ou le moniteur universel 23, no. 173, 23 ventôse, l'an III (13 March 1795), Séance du 21 ventôse (11 March), p. 661.

86 Foreigners could acquire citizenship after they had attained the age of 21, signed a declaration of intent of settling in France, resided in France for seven consecutive years, and possessed landed property or an agricultural or commercial establishment, or were married to a French woman. 
the name of abstract equality. Assigning the 'eminent droit de cite', or political rights, to 'sans-culottes', to those 'without a house, without inheritance', to those 'who possess no part of the land at all', was in Dupont de Nemours's view like 'arming' a class of people 'who have nothing to lose' and 'who form no political society'. Granting the propertyless class political rights amounted to placing them 'in a state of open revolt against the nation'. Limiting political rights to property owners, on the other hand, would 'everywhere stimulate a love for labour. ${ }^{7}$ In good Physiocratic fashion, Dupont de Nemours's 'nation' consisted of landed property owners ('propriétaires $d u$ sol'); they form a 'political society' and are entitled to the 'droit de cité.' 'Property owners', as he put it, 'without whose consent no person in the country is able to lodge or eat, are citizens par excellence.' 88

The requirement of land ownership was attacked both within and outside the convention, by Roederer among others. ${ }^{89}$ Significantly, the constitution that was ultimately accepted did not specify what counted as 'property': electors were to either own property 'yielding a revenue equal to the value of 200 days of work', be tenants paying rent which equals 150 days of work, or own rural property yielding a revenue equivalent to 200 days of work. ${ }^{90}$ The silence of the constitution of year III on the precise nature of property suggests that industrial and commercial assets, stocks, and real estate were also deemed adequate, which indicates that many believed that propertied citizens engaged in commerce and industry were to be fully included in the republic's ruling class. $^{91}$

The severe limitations placed on the number of those citizens eligible to elect national representatives were challenged from the left, but never endangered. One representative who strongly opposed the property requirements was none other than the 'transatlantic patriot' Thomas Paine. Revealing of the

87 P.S. Dupont de Nemours, Observations sur la constitution proposée par la commission des onze et sur la position actuelle de la France (Paris: Du Pont Imprimeur,1795), p. 10.

88 P.S. Dupont de Nemours, Observations sur la constitution, pp. 7-8.

89 Cf.Jainchill, Reimagining Politics after the Terror, pp. 44-45.Jainchill sees the Commission's original proposal of the requirement of land ownership for becoming an elector as another indication of the classical-republican views of Thermidorians. It is telling that this requirement was in fact ultimately rejected by the National Convention.

90 Titre IV, article 35 reads: 'celle d'être propriétaire ou usufruitier d'un bien évalué à un revenu égal à la valeur locale de deux cents journées de travail, ou d'être locataire, soit d'une habitation évaluée à un revenu égal à la valeur de cent cinquante journées de travail, soit d'un bien rural évalué à deux cents journées de travail'.

91 As one of the requirements stipulated for foreigners to become French citizens the constitution mentions in title II, article 10 landed property or an agricultural or commercial establishment. 
new wind that was blowing, however, was that his passionate plea for universal suffrage, and his accusations addressed at the Convention for betraying the grand object of the Revolution', hardly seem to have made any impression. ${ }^{92}$ Paine would never again return to the floor of the Convention.

The language of property, of having a stake in society, thus, found its way into the constitution's stipulations on becoming an elector. The Thermidorian's insistence on the necessity of labour as the foundation of citizenship and 'order', a language that was by nature less exclusivist but instead potentially more expansive in its implications for the scope of citizenship, found its way in the definition of 'regular' citizens who only had a voice in the primary assemblies. Next to the requirements already mentioned, 'young men' had to prove that they could read and write, and had a 'profession' ('profession mécanique'). The reasoning behind the inclusion of this last requirement is different from the property requirement for electors, and seems directly related to the fears Thermidorians frequently expressed about men getting absorbed in revolutionary politics, especially young men.

Why was the condition of owning property considered to be so important? First of all, it was widely assumed that only property owners had a particular concern for good government and stability. As Adrien Lezay-Marnésia, a publicist known for his public quarrels with Benjamin Constant, summarized, property-owning citizens not only 'have the right to rule the city, but they alone have an interest to rule it well'. ${ }^{93}$ Property owners and the propertyless, then, not only differ in 'nature', Lezay-Marnésia explained, but more fundamentally differ in 'spirit': the spirit of the 'have's' is one of preserving; they desire 'an order that preserves'. The spirit of the 'have-not's' is one of overthrowing; they wish 'disorder to replace it'. ${ }^{94}$ Men without property were dismissed by LezayMarnésia as 'a wandering and savage horde'. The 'propertyless inhabitant' was in his view simply an 'inhabitant'. A citizen, on the contrary, is a 'member of the cité, an 'inhabitant-property owner'. The terms of the arguments expounded by Lezay-Marnésia, Boissy, and Dupont de Nemours - 'savage state,' 'wandering horde', vis-à-vis 'political society', 'the cité' - reflect their preoccupation with a civilizational minimum one has to attain in order to be assigned full citizenship. The crucial marker for this minimum level of civilization was, in their view, the ownership of property. Owning property, then, was deemed a fairly

92 Thomas Paine delivered his speech in the National Convention on July 7, 1795. Réimpression Gazette national ou le Moniteur universel 24, pp. 171-172.

93 A. Lezay, Les ruines ou voyage en France pour servir de suite à celui de la Grèce (Paris: Migneret, 1796), p. 31. Lezay's Les ruines ou voyage en France was first published in 1794 and went through four editions between 1794 and 1796 . 
reliable indicator of one's general independent standing, both materially and intellectually. Only property owners were thought capable of living up to the civilizational standard.

Finally, the notion of the property owner as the model of centristThermidorian citizenship discourse arose in close connection with the idea that citizens ought to be autonomous, ought to think independently, and in a general sense, show a measure of enlightenment. Again, this idea was hardly new of course. But it gained new prominence and became explicitly related to the experience of the Terror. In a speech delivered on July 9, Lanjuinais asked his audience: 'Who of us can still recall the hideous spectacle of political assemblies in the grip of grime ignorance, founded on greed, on villainous exhilaration'95 $\mathrm{He}$ was quick to draw the implications from his recollection:

[I] t's impossible that all men enjoy their political rights; it is permitted to determine the conditions required for their exercise. Undoubtedly this requires no more than asking those to whom they obtain, reason, intelligence, and the necessary will and interest to maintain order. [...] Will we call up men who own nothing to exercise their political rights, even if need puts them to the mercy of the former who pays them? The time of popular flattery is over; we will give a negative response. ${ }^{96}$

The prerequisite of a citizen's 'independence' especially came to the fore in the discussions about literacy and the requirement of exercising a 'mechanic profession' on 12 and 14 July. Boissy had stated in his preliminary speech in name of the Commission that in order to 'exercise political rights', a citizen must be 'free and independent' ${ }^{97}$ This condition of freedom and independence comprises 'the faculty of knowing how to read', which 'ought to be regarded as a sixth sense, the development of which can only render us real men, and by consequence, citizens. ${ }^{98}$

The requirement of literacy proposed by the commission drew heavy criticisms, despite extensive speeches made in its favour. Deputy and member of the Commission of Eleven Jacques Antoine Creuzé-Latouche, who supported the requirement, was appalled by 'the idea that a man, who, although healthy

95 Réimpression Gazette nationale ou le moniteur universel 25, no. 295, 25 messidor, l'an 3 (13 juillet 1795), Séance 21 messidor, p. 196.

96 Ibid.

97 Boissy, Projet de constitution pour la République français, et discours préliminaire, p. 34.

98 Ibid., p. 35 . 
and strong, is reduced to appealing to the assistance of someone else'. 'What useful part can he play in the political affairs of society', he asked, 'if he doesn't know how to judge them, how to examine them, how to ascertain his own proper will?'99 Critics such as the representatives Charles Lacroix and JeanJacques Cambacérès pointed out that France had not yet reached the point at which the means of education were adequately dispersed throughout the nation. 'Do you want to establish a genuine scientific aristocracy?', Charles Lacroix bitingly asked. ${ }^{100}$ After this first session of debate, the articles were not put to the vote but returned to the Commission. A few days later, chairman of the Commission Pierre-Claude-François Daunou reported the deliberations of the Commission to the National Convention. They had taken the objections seriously, he said. Significantly, Daunou drew a connection between the Montagnard regime and the supposed lack of intellectual capacities of the mass. 'We have all witnessed the dangers of admitting in the primary assemblies men who don't know how to read or write', Daunou had earlier reminded the National Convention. ${ }^{101}$ Taking a step back Daunou made the observation that the revolution as such was made possible by the 'progress of philosophy', and, moreover, by the 'communication between enlightened men and the most numerous part of the people.' During the ancien régime the 'oppressors' had deliberately kept the people ignorant and knowledge from spreading. Under the Jacobin regime, however, 'the fierce bandits [...] aimed at the same goal, arrived at the same results' but 'with another language':102

It was no longer the case that the people were declared unworthy for education, it was education that was denigrated as superfluous or perilous within the bosom of the people who were said to be free and regenerated. Ignorance was called reason, incompetence wisdom. Enlightened men were denounced as enemies of equality. Every man who was more enlightened than another was judged a less good citizen, less worthy of public confidence, inepter for social functions; it is in this way that the factious always flattered part of the people, in order to degrade and subjugate them; as they plunged them in the thickest darkness, in the vilest corruption,

99 Réimpression Gazette nationale ou le moniteur universel 25, no. 299, 29 messidor III (17 juillet 1795), Séance du 24 messidor (12 July) p. 224.

100 Ibid., p. 227.

101 Ibid.

102 Réimpression Gazette nationale ou le moniteur universel 25, no. 301, 1 thermidor, l'an III (19 juillet 1795), Séance du 26 messidor (July 14), p. 243. 
they said to them:you are good, you are wise, you are sovereign; No one has the right to be more than you. ${ }^{103}$

Daunou's argument that the Jacobins' alleged scorn of intellectual distinction left so many French citizens in a state of political and intellectual subjection served to make a more constructive case for forging an independent citizenry. The requirement of literacy would serve as an incentive to bring that about. Daunou, then, simultaneously wanted to restore and defend a legitimate degree of 'distinction' within the body politic, which, as we have seen, was a commonplace of Thermidorian rhetoric. Lanjuinais stated it thus: '[I]t is necessary that the blind are led by those who can see; it is necessary that those, to whom intelligence was not given, agree to select those others as guide.'104 But the paramount expression of the need for a distinct class of citizens was Boissy's, who linked it to the condition of owning property:

We must be governed by the best; the best are the most instructed and most interested in maintaining the laws; for, with a few exceptions you will find such men among those who possess property, are attached to the country which contains it, [and] to the laws that protect it [and to] education which renders them suitable to discuss with sagacity and accuracy the advantages and inconveniences of the laws which determine the fate of their country. ${ }^{105}$

A distinct class of wealthy, enlightened citizens, sometimes referred to as 'notables', were considered the rightful backbone and ruling elite of the postTerror French Republic.

The 'good citizen' of the Thermidorian center, which was originally employed as a term to rally broad segments of the French population behind the post-Terror regime and create national unity, had become an exclusive notion. This model of citizenship meant a drastic reorientation compared to the, at times militant, patriotic and politicized understandings of citizenship in the period 1793-1794. The citizen was detached from the popular societies so as to render him harmless, isolated, and in an unmediated relationship to the centralized national representative body, the sole legitimate site of politics. One of the

103 Réimpression Gazette nationale ou le moniteur universel 25, no. 301, 1 thermidor, l'an III (19 juillet 1795), Séance du 26 messidor (July 14), p. 243-244.

104 Réimpression Gazette nationale ou le moniteur universel 25, no. 295, 25 messidor, l'an 3 (13 juillet 1795), Séance 21 messidor (9 July), p. 196.

105 Boissy, Projet de constitution pour la République français, et discours préliminaire, pp. $3^{2-} 33$. 
main legacies of Thermidorian reflection on the Terror was the association of faction with popular societies. From then on, popular societies, and by extension, organised opposition, were by default suspect. The Thermidorian attempt to nationalise citizens through a discourse of 'good' citizenship failed, partly because large numbers of citizens were denied access to the political sphere. This failure of rallying diverse groups of citizens behind the Republic paved the way for Bonaparte's takeover.

The citizen was expected to put his energy into labour, commerce, industry, the arts, and education. Equality was redefined in terms of the equal protection of one's (civil) rights by the law. Often explicitly referring to the involvement of what were considered the propertyless and uneducated masses, the Thermidorian centre considered only the propertied and educated (or enlightened) to be eligible for full-fledged citizenship. Taken together, the notion of post-Terror citizenship that dominated Thermidor and the Directory was a depoliticized model of citizenship. The following chapters on the American and Dutch republics reveal both patterns similar to those in France, and processes determined by the national circumstances of the country in question. 


\section{The Post-Revolutionary Contestation and Nationalization of American Citizenship}

On July 17th, 1799, the poet, editor, and publicist, Robert Treat Paine Jr. delivered an oration at a meeting of the Committee of the Young Men of Boston. ${ }^{1}$ In this oration, Treat Paine commemorated the annulment of the 1778 Treaty of Alliance with France. The Franco-American defensive alliance against British military aggression forged in the midst of the American Revolutionary War had lasted for exactly twenty years. Its dissolution, approved by Congress on July 7, 1798, as France and the United States were locked in an undeclared naval war, was not simply the end of a military pact, Treat Paine made clear, but symbolized a deep political and intellectual rift between the 'sister republics'. 'The struggle between Liberty and Despotism, Government and Anarchy, Religion and Atheism, has been gloriously decided', Treat Paine commenced his oration. 'It has proved the victory of principle, the triumph of virtue. France has been foiled, and America is free.' ${ }^{2}$

Treat Paine did not deny that France was once 'considered an amiable nation.' ${ }^{3}$ For his graduation ceremony at Harvard in 1792, he had written a poem tellingly entitled The Nature and Progress of Liberty in which he, like so many Americans had done at the time, expressed his admiration for the revolution in France. 'May struggling France her ancient freedom gain, May Europe's sword oppose her rights in vain', some of the more expressive lines of the poem read. Following a couplet in which the young graduate wished Edmund Burke's fame to rest in 'dark oblivion', the poem went on to record the intimate

1 Robert Treat Paine Jr. (1773-1811), son of the Massachusetts lawyer and politician Robert Treat Paine (1731-1814), one of the signers of the Declaration of Independence, was born Thomas Paine. Partly to make sure he would not be confused with the famous Anglo-American revolutionary pamphleteer Thomas Paine (1736-1809), Thomas Treat Paine changed his first name into Robert, the name of his deceased brother, in 1801. To avoid any confusion, I will refer to him as Robert Treat Paine Jr. or Treat Paine.

2 Thomas Paine [Robert Treat Paine Jr.], An Oration, written at the Request of the Young Men of Boston, and delivered, July 17th, 1799: In Commemoration of the Dissolution of the Treaties, and Consular Convention, between France and the United States of America (Boston, MA: J. Russell, 1799), p. 5 (italics in original). A second edition of the oration was issued in the same year.

3 Treat Paine, An Oration, p. 11 (italics in original). 
bond between 'Columbia's freedom' and the transatlantic language of the 'rights of man', the 'noblest epoch on the historick page!'

However, Treat Paine's solidarity with the French Republic soon deteriorated. In the middle of the 179os, he became the editor of the Boston Federal Orrery, a staunchly Federalist newspaper that was at the frontline of the attacks directed at the democratic-republican societies (viewed by Treat Paine as American incarnations of the French Jacobin clubs). 'Who has forgotten that dubious aera in our history', he asked his public in his 1799 oration, 'when illuminated fraternities were scattered', when 'anarchy and disorganization were the order of the day', and when 'our "civick feasts" were introduced to celebrate French victories?'5 Next to his editorial work, Treat Paine contributed to the forging of an anti-French American national discourse through his 1798 song, Adams and Liberty, perhaps the most popular American patriotic song of the late 1790s. The contrast between the French and American republics was a recurrent theme in the song's lyrics: 'While France her huge limbs bathes recumbent in blood, And Society's base threats with wide dissolution; May Peace like the dove, who returned from the flood, Find an ark of abode in our mild constitution: ${ }^{6}$ Many of those present in the audience on July 17 , 1799, were most likely familiar with the song, or perhaps had once sung along with it.

Treat Paine's published oration for the Committee of the Young Men of Boston, printed in several newspapers, and highly praised by both ex-president George Washington and president John Adams, who considered it 'an effort of a pregnant and prolific genius [...] excited by the purest motives, and governed by the best principles', was thus the endpoint of his ongoing reflection on France's revolutionary republic. Considering that 'the modern Frenchman is educated in a system of moral and religious chimeras', Treat Paine declared at the closing of the tumultuous decade that the 'exulting Ocean [that] now rolls between our shores' is 'an eternal monument of our separation'?

One of the contentions of this chapter is that this story about Robert Treat Paine Jr's intellectual Werdegang is exemplary of a larger transformation in how

4 'The Nature and Progress of Liberty', in: The Works in Verse and Prose of the late Robert Treat Paine, Jun. Esq. with notes. To which are prefixed Sketches of his Life, Character and Writings (Boston, MA: J. Belcher, 1812), pp. 70-77, at p. 75 .

5 Treat Paine, An Oration, p. 20 (italics in original).

6 T. Paine [Robert Treat Paine Jr.], Adams and liberty. A New Patriotic Song (Baltimore, MD: Hanna and Greene, Thomas, Andrews \& Butler, and Solomon Cotton \& Co, 1798). Adams and Liberty had the same tune as the future national anthem The Star-Spangled Banner (originally the tune of To Anacreon in Heaven). See C. Warren and N. Ames, Jacobin and Junto; Or, Early American Politics as viewed in the Diary of Dr. Nathaniel Ames, 1758-1822 (Cambridge, MA: Harvard University Press, 1931), p. 76.

7 Treat Paine, An Oration, p. 11. 
broad segments of American citizens came to evaluate the radicalization of the French Revolution and the Terror. Moreover, this chapter explores what the implications were for the ways in which Americans came to conceptualize citizenship. Building on the work of historian Seth Cotlar and others, I argue that by the late 1790 s and early 1800 , both Federalists and Republicans conceived the notion of American citizenship in decidedly anti-Jacobin, and eventually antiFrench and 'anti-transatlantic' terms. Like Treat Paine, until 1792 most American citizens had praised the French Revolution and the ideals they associated with it. As this chapter demonstrates, from 1793 onwards, within the context of an emerging Republican-Federal partisanship, interpretations of the radicalization and violence of the French Revolution began to diverge. It then goes on to examine how the rise of democratic-republican societies shifted the focus of Federalist reflection, in publications such as Treat Paine's Federal Orrery, to the Jacobin clubs, and moreover, to the ways in which the Jacobin Terror threw an ominous light on the model of democratic citizenship as propounded by these societies. The final section argues that after 1795 reflection on the Jacobin Terror took on new dimensions, as conservative clergymen, motivated partly by anxieties about the religious state of the American people, began to portray the Jacobin Terror as the outcome of a dangerous atheistic philosophy. A wave of antiJacobin conspiracy theories contributed to the blackening of the American 'illuminated fraternaties', as Treat Paine called them. The Terror was accordingly reinterpreted as the empirical substance within a broader counter (French) enlightenment critique that came to serve as one of the foundations of a distinct conception of American citizenship based on order, Christian virtue, and the constitution (excluding slaves, free blacks, women, and native Indians). In the context of the undeclared naval war of 1798-180o, better known as the 'QuasiWar' between the French and American republics, which provided the occasion for Treat Paine's oration, the chapter shows how both Republican and Federalist publicists forged a nationalized conception of American citizenship, and shattered the horizon of a shared transatlantic ideal.

In the early American Republic, the first stages of the French Revolution met with nearly universal approval across the entire political spectrum. ${ }^{8}$ However,

8 L.S. Kramer, 'The French Revolution and the Creation of American Political Culture', in: Klaits and Haltzel (eds.) The Global Ramifications of the French Revolution, pp. 26-54; Wood, Empire of Liberty, pp. 174-175; S.M. Elkins and E.L. McKitrick, The Age of Federalism (New York, N.Y.: Oxford University Press, 1993), pp. 309-310. 
whereas initially the American public generally interpreted the French Revolution as a confirmation of their own revolution, the radicalization in 1792, and the Jacobin Terror in particular, generated highly politicized and conflicting interpretations. The contested interpretations took place within the context of an emerging of political partisanship between Republicans and Federalists. ${ }^{9}$ Neither Republicans nor Federalists identified themselves as being a 'party' in the sense that they believed that there was a multiparty system in which several parties legitimately competed for power. ${ }^{10}$ Essentially, both Republicans and Federalists saw themselves as representing and expressing the only legitimate vision on the American polity and its future, and the other as a threat to the accomplishments of the revolution. News of the violent and intense political conflicts in revolutionary France put this incongruence in the American Republic between the professed classical ideals of unity and the reality of increasing political division in a gloomy perspective.

In addition, a profound sense of the instability of the American republican experiment characterized the 179os. Unlike earlier generations, historians nowadays recognize that the 1790 s were a period beset with conflict, uncertainty, and fear about the fate of the infant American republic..1 The international crises and revolutionary wars in Europe demonstrated to Americans that they could not take their survival as an independent state for granted. The new American constitution had replaced the Articles of Confederation as of March 4, 1789, establishing a national government with a Congress (Senate and House of Representatives), an executive office of President, and a Supreme Court. But it left unanswered central questions about how, in practice, the relationship between national representatives and their constituents would take shape, how and through what channels the 'will of the people' was to be determined, and what role citizens should play in the public sphere. The nature and limits - of the political substance of citizenship were anything but settled. ${ }^{12}$

$9 \quad$ See Chapter three.

10 Even Madison, acknowledging the existence of two 'parties' in 1791, did not approve of the existence of two parties, but saw one party - the Federalist - as 'evil'. Elkins and McKitrick, The Age of Federalism, pp. 266-268.

11 Sharp, American Politics in the Early Republic; Wood, Empire of Liberty. For an older historiography which stresses the passionate and discordant nature of the 1790, see J.R. Howe Jr., 'Republican Thought and the Political Violence of the 179os', American Quarterly 19 (1967), pp. 147-165; M. Smelser, 'The Jacobin Phrenzy: The Menace of Monarchy, Plutocracy, and Anglophilia, 1789-1798', The Review of Politics 21 (1959), pp. 239-258; M. Smelser, 'The Federalist Period as an Age of Passion', American Quarterly 10 (1958), pp. 391-419.

12 Cf. Bradburn, The Citizenship Revolution, p. 3: 'The significance of the ratification of the Constitution is highly overestimated with regard to the definition of citizenship and its institutional settlement. Instead the conflicts of the 1790 s created the political settlement 
Precisely because the American republic was entering uncharted waters, the vicissitudes of the new French Republic became such important points of reference.

If the French Revolution enabled Americans to take stock of their own situation, they did so at a moment in time when the very limits of the American public sphere were explored and tested. The 1790 saw an unparalleled increase, often inspired by and organized around key moments of the French Revolution, of public festivities, parades, and celebrations, an expanding (transatlantic) book and pamphlet market, the emergence and manifestation of popular democratic societies in 1793-1795, and above all, the expansion of a democratic press that was able to reach and connect to a broader reading public than ever before. These public festivities, popular societies, and democratic newspapers drew heavily on the universalistic and egalitarian language of the French Revolution and involved the participation and representation of social groups that were largely excluded from the political system but were now increasingly claiming their place, or given a voice, in the public sphere. The responses to, and interpretations of the French Revolution's radical phase of the Terror were thus formed at a time when the public manifestation of politically engaged groups of citizens were lauded by some and feared by others. Partisanship and opposition was not only a phenomenon in the realm of high politics but was increasingly taken to the streets. In the revolutionary and crisis-ridden atmosphere of the 179os, the pertinent and all too realistic question the Terror raised, then, was when this opposition would turn into civil disorder, anarchy, and in the most drastic case, lead to the destruction of the republic. ${ }^{13}$

Established historiography tends to present the representation of, and responses to, the radicalization of the French Revolution as a more or less static partisan (Republican-Federalist) affair, determined by domestic political allegiances. ${ }^{14}$ Indeed, the political landscape was increasingly determined by the emergence of the Federalist-Republican division. Yet, in what follows, I first try

of the American Revolution and fashioned the assumptions, compromises, and political alliances that defined the potential of American citizenship and the character of national politics in the antebellum United States'.

13 Cotlar, Tom Paine's America; S.P. Newman, Parades and the Politics of the Street: Festive Culture in the Early American Republic (Philadelphia, PA: University of Pennsylvania Press, 1997); J.L. Pasley, 'The Tyranny of Printers': Newspaper Politics in the Early American Republic (Charlottesville, VA: University Press of Virginia, 2001); Pasley, Robertson, and Waldstreicher, Beyond the Founders; D. Waldstreicher, In the Midst of Perpetual Fetes: The Making of American Nationalism, 1776-1820 (Chapel Hill, N.C.: University of North Carolina Press, 1997).

14 G.B. Nash, 'The American Clergy and the French Revolution', The Williamand Mary Quarterlyz2 (1965), pp.392-412;A.W. Robertson, "Look on This Picture... And on This!" Nationalism, 
to convey a sense of the initial astonishment that struck so many Americans by just observing the astounding series of revolutionary events that were taking place in France. The terms of evaluation and ways of representing the radicalization of the French Revolution were more in flux than most historians have argued for. In addition, if present-day historians disagree about the nature of the Terror, and when it started, it is not surprising that among the American public of the 1790s, basing themselves on limited and coloured information, there was even less consensus about what distinguished radical politics from popular violence, or state-centred terror from emergency measures..$^{15}$ Paying attention to the step from initial response to more systematic reflection allows us to see what aspects of the Jacobin Terror were picked out or emphasized at what moments, and moreover, what implications were drawn from it to reconsider or confirm existing - ideals of citizenship at the time.

Many of the initial responses to the news of the radicalization and violence of the French Revolution tended to interpret it as a lamentable but unavoidable aspect of revolutionary struggle. Even a prominent Federalist publicist such as Noah Webster in 1793 initially interpreted the revolutionary violence within the grander scheme of 'a great and enlightened people struggling [...] to break down the feudal and hierarchical systems of despotism. ${ }^{16}$ Webster was fully aware of the tragedies that accompanied the upheaval in France and expressed his sympathy by calling upon his readers to 'drop a tear over the calamities that attend the French revolution'. At this point Webster still saw the calamities as 'inseparable from such great changes and events' and held that they could be ascribed to 'the treachery and perjuries of their perfidious domestic foes'. Webster's estimation of the fate of France was overall still optimistic, and he appeared willing to 'let reason smile at the prospect of peace in that new born republic'. He expressed the hope that 'when an energetic executive shall be constituted by the unbiassed suffrages of enlightened citizens, armed with the whole power of the nation', in the end things might turn out rather well. ${ }^{17}$

Localism, and Partisan Images of Otherness in the United States, 1787-1820', American Historical Review 106 (2001), pp. 1263-1280; Smelser, 'The Jacobin Phrenzy'.

15 On different interpretations of the Terror see, D. Andress, 'The Course of the Terror, 17931794', in: McPhee (ed.) A Companion to the French Revolution, pp. 293-310.

16 N. Webster, Effects of Slavery, on Morals and Industry (Hartford, CO: Hudson and Goodwin, 1793), p. 31.

17 Webster, Effects of Slavery, on Morals and Industry, pp. 31-32. 
Webster was not the only Federalist publicist to give the French Revolution the benefit of the doubt. In his 1793 Fourth of July oration in Boston, John Quincy Adams, son of Vice-President John Adams, and appointed ambassador to the Dutch Republic by the Washington administration in November that same year, naturally pictured the spirit of the French Revolution as originating from the 'principles' of American independence. Although turning his attention to the 'torrent of destruction' and the 'scaffold, smoking with the blood of the fallen monarch', John Quincy Adams still urged his listeners to 'rather indulge the pleasing and rational anticipation of the period when all the nations of Europe shall partake of the blessings of equal liberty and universal peace', as the 'the system of feudal absurdity has received an irrecoverable wound. 18 Equally, the politician and prominent historian of the American Revolution, David Ramsay, a supporter of the Federalists throughout the 179os, in his 1794 Fourth of July oration in Charleston, South Carolina, criticized 'the abettors of tyranny' who 'are anxiously looking for opportunities to discredit the new doctrines of the rights of man', as the 'eyes of the world are fixed on this country and on France'. Although he upheld the American nation as 'example' to other (European) nations, to show that 'genuine republicanism is friendly to order and a proper subordination in society' and 'that it is hostile to mobs and licentiousness of every kind', he had not given up on France. For France is 'daily proving, that a handful of citizens, fighting under the banners of liberty, is more than a match for an host of mercenaries, engaged in support of tyranny'. ${ }^{19}$

The sometimes bickering partisan perspectives on the course of the French Revolution of the mid and late 179os sometimes tend to overshadow the initial attitude of many Americans toward their new sister republic, namely that of detached astonishment. A perceptive comment in the Apollo; or, Chestertown Spy (Maryland) of May 31, 1793, shows this attitude:

We now touch on a new aera of a revolution which has been continually varying its form, and giving rise to fresh changes; a revolution which has astonished ordinary observers, by the novelty, magnitude, and rapid

18 J.Q. Adams, An Oration, Pronounced July 4th, 1793, at the Request of the Inhabitants of the Town of Boston (Boston, MA: B. Edes \& Son, 1793), p. 19.

19 D. Ramsay, 'The Oration of 1794', in: R.L. Brunhouse (ed.) 'David Ramsay, 1749-1815: Selections from His Writings', Transactions of the American Philosophical Society 55 (1965), Part IV, pp. 190-196, at p. 196. Ramsay's oration was delivered in St. Michael's Church at the request of the American Revolution Society and published afterwards. Ramsay was by then an established historian and author of The History of the Revolution in South-Carolina, From a British Province to an Independent State, 2 vols. (Trenton, N.J.: Collins, 1785) and The History of the American Revolution, 2 vols. (Philadelphia, PA: Aitken, 1789). 
succession of events; which has filled with horror the friends of humanity, by the crimes which it has produced, and the evils with which it has produced, and the evils with which it threatens humanity; and which has opened a new field of curiosity and speculation to the philosopher, while it baffles every effort of reasoning and conjecture. ${ }^{20}$

The quick succession of revolutionary events in particular perplexed the ordinary American observer. 'In France the gradations from despotism to limited monarchy; from limited monarch to republicanism; from republicanism to democracy; and from democracy to anarchy, have been extremely rapid', one commentator noted, 'and still the French go on in their wild career.' ${ }^{21}$ Indeed, even from a distance, the radicalization of the French Revolution seemed to 'accelerate time. ${ }^{22}$ Because of the astonishing pace and unpredictable chain of events, and because information was both partial and coloured, it should come as no surprise that a great many Americans for a while remained simply undecided on how to evaluate the turn the revolution in France had taken. 'Whether France is saved or ruined, is still problematical' and 'whether in the end, France will be blessed with a free constitution, securing to her the blessing of equal liberty [...] is a point to be developed in time', an 'American citizen' conceded in September 1794, just before the news of Robespierre's fall would reach the United States. Clearly, the author wrote, from the 'scenes of devastation, blood and carnage, the humane and enlightened citizens of America cannot but turn with indignant horror'. But it was still too early to turn one's back to France, he felt, "because the cause of France is ostensibly the cause of liberty, though, by all accounts, the nation never was in greater bondage than now; we view it is a glorious cause, and seem disposed to palliate the dreadful excesses by which it has been marked., ${ }^{23}$

Finally, it is important not to overlook an influential stream of Republican political millennialism coming from the pulpit that, until 1794-1795, interpreted the violence and radicalization of the French Revolution in providential and eschatological terms. ${ }^{24}$ The New York Presbyterian minister Samuel Miller, for instance, orated that, however 'this wonderful Revolution' may 'appear to

20 Apollo; or, Chestertown Spy (Chestertown, Maryland), May 31, 1793.

21 The South-Carolina State-Gazette (Charleston, South Carolina), November 25, 1794.

22 M.R. Hale, 'On Their Tiptoes: Political Time and Newspapers during the Advent of the Radicalized French Revolution, circa 1792-1793', Journal of the Early Republic 29 (2009), pp. $191-218$.

23 Greenfield Gazette (Greenfield, Massachusetts), September, 18, 25, 1794.

24 R.H. Bloch, Visionary Republic: Millennial Themes in American Thought 1756-1800 (Cambridge: Cambridge University Press, 1985), 150-187; N. Guyatt, Providence and the Invention 
be sullied by irreligion and vice, it is the cause of God'. ${ }^{25} \mathrm{He}$ did so in a sermon that was printed at the request of the (increasingly) democratic-republican Tammany Society, and printed by one of Massachusetts leading democratic printers and editor of the (democratic) New-York Journal, Thomas Greenleaf. Another typical sermon acknowledged the 'excesses' and 'cruelties' but declared that France may be 'excused' and that 'America cannot tax her with defect of friendship or candour'. ${ }^{26}$ As Ruth Bloch has suggested, this Republican millennialism, elaborated mostly by Baptists and Presbyterians, was not so much part of a partisan political debate but rather must be situated within popular culture. ${ }^{27}$ It was only from 1795 onwards, when the more conservative clergy vehemently turned against the French Revolution, that religious interpretations became politically inflammable. Nonetheless, earlier republican millennial responses to revolutionary violence contributed to a widely held view that the revolutionary violence in France was extraordinary and frightening, but excusable in light of the bigger picture.

From 1793 onwards, responses to the radicalization of the French Revolution became increasingly polarized. The execution of Louis XVI in January, and the declaration of war against Great Britain in February 1793, forced Americans to decide whose side they were on. ${ }^{28}$ The Washington administration's neutrality proclamation was decried loudly by democratic Republicans, and exacerbated the rift between Federalist Anglophiles and Republican Francophiles. In addition, the proclamation of the French Republic as well as the military successes of the French republican army prompted Americans throughout the country, from Charleston to New York and Lexington (Kentucky), to organize celebrations, feasts, and festivals. ${ }^{29}$ Thousands of ordinary citizens, white and black, women, and children, took to the streets, singing French songs, waiving French flags, and toasting to 'liberty and equality'. The festivities in Boston that began on January 24,1793 , were among the biggest public ceremonies of the decade and were reported extensively in numerous local and distant newspapers.

of the United States, 1607-1876 (New York: Cambridge University Press, 2007), pp. 146-150; Nash, 'The American Clergy and the French Revolution'.

25 S. Miller, A Sermon, preached in New-York, July 4th, 1793: Being the Anniversary of the Independence of America, at the Request of the Tammany Society, or Columbian Order (New York, N.Y.: T. Greenleaf, 1793), p. 32.

26 J. Lathrop, The Happiness of a Free Government, and the Means of Preserving It: Illustrated in a Sermon, Delivered in West-Springfield, on July 4th, 1794, in Commemoration of American Independence (Springfield, MA: Hutchins, 1794), p. 15.

27 Bloch, Visionary Republic, p. 154.

28 C.D. Hazen, Contemporary American Opinion of the French Revolution (Baltimore, MD: The Johns Hopkins press, 1897), pp. 254-256.

29 Newman, Parades and the Politics of the Street, pp. 120-151. 
Such festivities, one Massachusetts newspaper reported, welcomed 'every class of Citizen patriots', promising that social distinction would be 'abolished by the title of Citizens. ${ }^{30}$ To Federalists, who virtually never participated in them, these public manifestations constituted frightening scenes, especially in combination with the fierce attacks on the 'aristocratic' Washington administration. More radical elements, such as re-enactments of the beheading of the French king and the setting up of guillotines, even if sporadic, proved to them that the climate of opinion had hardened. ${ }^{31}$

At the same time, the influx of British, Irish, and Scottish middleclass radicals, many of them driven into exile by loyalist and government repression, strengthened the Federalist perception that the wave of European radicalism would cross the Atlantic, or had already done so. These 'transatlantic radicals' were soon caught up in the political controversies of the day. A significant number of them ended up in editorial positions, print business, and as members of democratic societies. ${ }^{32}$ Often ardent supporters of the French Revolution endorsing a Painite cosmopolitanism, they only heightened Federalist anxiety that what they saw as the excesses of radical popular democracy would spill over to American soil.

Finally, with the arrival of the French ambassador Edmond or 'Citizen' Genet in Charleston, South Carolina, on April 8, 1793, the radicalized French Revolution literally seemed to have landed on American shores. Genet was greeted enthusiastically in the overwhelmingly pro-French port-city Charleston. Welcome receptions and addresses were held in almost every town Genet visited on his way to the capital, Philadelphia, where his mission would consist of trying to win over the American government to aid the French in their war against the British. For reasons that have to do with his diplomatic inexperience, clumsiness, and overconfidence, Genet managed to offend the entire Federalist administration by ignoring its official proclamation of neutrality. The Washington administration denied all Genet's requests to equip and allow American and French ships to carry out privateering raids on British ships, which would amount to a war declaration against Britain. Deeply frustrated, Genet then appealed directly to the American people, a move that was particularly bold in light of his close connections with democratic-republican societies in some parts of the country. Beginning on 31 July, 1793, a series of articles entitled

30 Massachusetts Mercury (Boston, Massachusetts), January 17, 1793, as cited in: Newman, Parades and the Politics of the Street, p. 127.

31 R.H. Cleves, The Reign of Terror in America: Visions of Violence from Anti-Jacobinism to Antislavery (New York: Cambridge University Press, 2009), p. 65.

32 M. Durey, Transatlantic Radicals and the Early American Republic (Lawrence, KS: University Press of Kansas, 1997). 
'No Jacobin', written unanimously by Secretary of the Treasury Alexander Hamilton appeared in Philadelphia newspapers. In these articles Hamilton frontally attacked Genet who 'has threatened to appeal from The President of the United States to the People'. He accused Genet of 'electrifying the people', of 'popular intrigue'; his actions were 'violations of our sovereignty', as he was trying to raise 'men [...] against the will of the government'. On top of that, as 'public newspapers' have made known, Genet was now an 'acknowledged member of a political Association'.33 In the years 1793-1794, when the country was receiving more dreadful reports on the Jacobin democratic experiment on the other side of the ocean, the Federalist reflection on the Terror shifted towards the very 'political associations' Hamilton was talking about.

\section{Political Societies, Faction, and the Limits of Democratic Citizenship}

Between 1793 and 1795, more than 40 democratic-republican societies were formed throughout the United States. ${ }^{34}$ The first, pioneering German Republican Society and the larger Democratic Society of Pennsylvania were founded in the nation's capital, Philadelphia. Soon democratic-republican societies sprang up in other major east-coast cities, while a considerable number were established in rural counties too. The founding document of the prominent Democratic Society of Pennsylvania declared that it was instituted 'with a view [...] to cultivate a just knowledge of rational liberty, to facilitate the enjoyment and exercise of our civil Rights, and to transmit, unimpaired, to posterity the glorious inheritance of free Republican Government'. These goals were to be achieved by means of 'a constant circulation of useful information, and a liberal communication of republican sentiments', the 'best antidotes to any political poison.' ${ }^{35}$ Members of democratic-republican societies were by and large drawn from the middle and lower classes, among them shopkeepers, artisans,

33 H.C. Syrett (ed.) The Papers of Alexander Hamilton, 27 vols. (New York, N.Y.: Columbia University Press, 1961-1987), vol. 15, 'No Jacobin no. 1', 31 July, 1793, p. 145; 'No Jacobin no. 5', 14 August, 1793, pp. 244, 246; 'No Jacobin no. 7', 23 August, 1793, p. 268. The articles appeared in Dunlap's American Daily Advertiser (Philadelphia, Pennsylvania) and were reprinted in several other newspapers.

34 E.P. Link, Democratic-Republican Societies, 1790-180o (New York, N.Y.: Columbia University Press, 1942); P.S. Foner, The Democratic-Republican Societies, 1790-180o: A Documentary Sourcebook of Constitutions, Declarations, Addresses, Resolutions, and Toasts (Westport, CT: Greenwood Press, 1976).

35 Independent Gazetteer (Philadelphia, Pennsylvania), July 13, 1793. 
and merchants, but also workingmen and mechanics. Local politicians, lawyers, and printers often constituted the leadership of the societies. ${ }^{36}$

By regularly organizing public or semi-public discussion meetings, celebrations, and feasts, as well as by publishing pamphlets, addresses, and newspaper articles, democratic-republican societies aspired to create an engaged and informed citizenry. Drawing on a classical-republican vocabulary, the democratic-republican societies deemed the established Federalist government deeply 'corrupted. ${ }^{37}$ Consequently, as the German Republican Society of Philadelphia put it, 'In a republican government it is a duty incumbent on every citizen to afford his assistance $[. .$.$] by his advice and watchfulness, that its principles$ may remain incorrupt; for the spirit of liberty, like every virtue of the mind, is to be kept alive only by constant action' ${ }^{38}$ Identifying themselves with examples set by the revolution in France, democratic-republican societies conceived of themselves as representatives of the people. As an 'Address to the Citizens of the United States' in the democratic Boston Argus in May 1793 stated: 'the partizans of Louis Capet alledge that clubs and mobs do every thing, against law, and the voice of the nation; but we believe, that those clubs and mobs are the nation itself. ${ }^{39}$ Democratic-republican societies believed that a healthy republic requires a vibrant and more open public sphere in which citizens play a politically active role; and they saw the platform of a democratic-republican society as the ideal 'mediating institution' to attain that goal. ${ }^{40}$

The democratic-republican societies' heightened presence in the American public sphere aroused suspicion and drew heavy criticisms from Federalist publicists and politicians alike. It was certainly not the case that Federalists discarded voluntary citizen associations tout court. The revolutionary political associations of the 1770s, such as Sons of Liberty and the Corresponding Societies, by which democratic republicans were undoubtedly inspired, were held in high esteem. Federalists duly acknowledged the need for, and value of, such associations in times of revolution. However, under the new constitutional order, there was no place for associations that in their eyes only sought to undermine,

36 Foner, The Democratic-Republican Societies, pp. 7-8; M. Schoenbachler, 'Republicanism in the Age of Democratic Revolution: The Democratic-Republican Societies of the 179os', Journal of the Early Republic 18 (1998), pp. 237-261.

37 Schoenbachler, 'Republicanism in the Age of Democratic Revolution'.

$38 \quad$ National Gazette (Philadelphia, Pennsylvania), April 13, 1793.

39 The Argus (Boston, Massachusetts), May 24, 1793.

40 'Mediating institution' is Albrecht Koschnik's term, see Koschnik, 'The Democratic Societies of Philadelphia', p. 617. See also his 'Let a Common Interest Bind Us Together'. Associations, Partisanship, and Culture in Philadelphia, 1775-1840 (Charlottesville, VA: University of Virginia Press, 2007). 
or worse, overturn established authorities. A further disconcerting novelty of the democratic-republican societies was that they did not shy away from public controversy and actively engaged in national and international political debates. They moreover sought publicity through a national network of newspapers. Benjamin Franklin Bache, the editor of one of the principal democratic opposition newspapers, the Aurora General Advertiser, was also one of the leading members of the Democratic Society of Pennsylvania. Through men like Bache, democratic-republican societies became connected through a network of newspapers and correspondents that passed on addresses, resolutions, and articles to each other, which led one worried Federalist to decry that the democratic societies have 'invested themselves with a disproportionate degree of power' and have become' the monopolizers of public opinion, and public influence.'41

Democratic-republican societies self-consciously launched themselves within the ambit of transatlantic revolutions. The 'Principles, Articles \& Regulations' of the Democratic Society of Pennsylvania, for example, commenced with the statement that the 'rights of man' have been 'clearly developed by the successive Revolutions of America and France'. Closely affiliated with the French Society of the Friends of Liberty and Equality (or French Patriotic Society), the Philadelphia societies played an important part in the grand reception and dinner to welcome Citizen Genet in late May 1793. 'The table was decorated with the tree and cap of liberty, and the French and American flags', the National Gazette reported. French songs were sung and toasts were drunk on 'Liberty and Equality', the 'Union and perpetual fraternity between the people of France and the United States' as well as on the 'liberty and success of the Dutch patriots - Généreux frères de la république / Amis des Bataves patriotiques. ${ }^{42}$

This celebration of the revolution of their Batavian frères proved to be slightly premature. But two years later, newspapers in Pennsylvania, New Hampshire, New York, and Maryland reported extensively on a 'civic festival' in Philadelphia celebrating the victorious Batavian revolutionaries. A large gathering of American, Dutch, and French citizens, saluted by gunshots, paraded 'with the three flags of the republics' to the French embassy where 'an altar was erected on which the Statue of Liberty was placed'. An address was held by a French citizen proclaiming that 'the soldiers of Liberty are everywhere triumphant'. He then proposed that everyone present to swear an oath in order to

$41 \quad$ Federal Orrery (Boston, Massachusetts), March 25, 1795.

42 National Gazette (Philadelphia, Pennsylvania), May 25, 1793. Reprinted in The Argus (Boston, Massachusetts), June 4, 1793. 
'cement among us the triple alliance of three republics' and to 'maintain political equality'. The Dutch, he went on, 'retain unimpaired the right of changing or amending their constitution'. The Minister of France, delighted by the spectacle, exclaimed: 'Long live the French Republic! - Long live the Republic of the United States! - Long live the Batavian Republic!' And while 'the air resounded with the cries of Long Live the Three Republics', 400 citizens adjourned to a nearby hotel where they feasted on a 'sumptuous repast'. 43

As was the case in Philadelphia, democratic-republican societies throughout the country would come to play an important part in organizing and shaping national and other public festivities celebrating the French - and occasionally the Batavian - Revolution. ${ }^{44}$ Next to declaring their brotherhood with French democrats, affiliated democratic newspapers reported regularly on the proceedings of Irish and British radical clubs, as well as the French Jacobin clubs. In doing so, members of democratic-republican societies, some of which adopted the French address of 'citizen' (instead of 'Sir'), were stimulated to imagine themselves as part of a larger transatlantic citizen emancipation movement. ${ }^{45}$

The democratic-republican societies voiced opinions that broadly overlapped with those of Madison, Jefferson, and the more mainstream Republican opposition (anti-British rhetoric, opposition to Hamilton's financial program, and disdain of Federalist elitism). Yet they largely developed alongside the national Republican leadership. Local public officials and politicians could sometimes be fully immerged in societies' activities and there are some examples of societies actively supporting the candidacy of their own members for state legislatures, and in one case for Congress. But on the level of national politics, Republicans were generally extremely reluctant to publicly sympathize with the societies, especially after democratic-republican societies were being associated with rebellion and sedition. ${ }^{46}$

43 Aurora General Advertiser (Philadelphia, Pennsylvania) April 20, 1795. The article was reprinted in: Philadelphia Gazette (Philadelphia, Pennsylvania), April 20, 1795; Dunlap's American Daily Advertiser (Philadelphia, Pennsylvania), April 21, 1795; Federal Intelligencer (Baltimore, Maryland), April 23, 1795;

Herald (New York, New York), April 25, 1795; New-Hampshire Gazette (Portsmouth, New Hampshire), May 5,1795 .

44 Newman, Parades and the Politics of the Street, pp. 92, 143; Waldstreicher, In the Midst of Perpetual Fetes, pp. 126-141.

45 Koschnik, 'The Democratic Societies of Philadelphia', p. 621.

46 S. Wilentz, The Rise of American Democracy: Jefferson to Lincoln (New York, N.Y.: Norton, 2006), pp. 59-61. 
Federalists considered the opposition of Republican politicians as a challenge to their political ideal of an elected natural aristocracy harmoniously deliberating the means to attain the common good. The democratic-republican societies' appearance in the national public sphere confronted them with a radical model of democratic citizenship outside the boundaries of what they considered to be a sound representative system of government. Confronted with this challenge that was of an entirely different nature than the top-down politics of the Republican gentry, Federalist interpretations of the radicalization of the French Revolution came to focus on the phenomenon of clubs and the role they played in the Terror of $1793^{-1794}$. Americans had decried the 1792 September massacres in and around Paris prisons somewhat vaguely as revolutionary violence. But over the course of 1793 and 1794 the role of Jacobin clubs, Parisian popular militia, and central committees, as well as the GirondinMontagnard split, mass prosecutions and executions were reported in greater detail in American newspapers. Accordingly, Federalists began to see and portray the democratic-republican societies through the lens of Jacobin clubism.

The large-scale violent uprising in western Pennsylvania that broke out in the Summer of 1794 over the national government's levy of excise taxes on distilled liquors, which grew into a frontier-wide movement better known as the 'Whiskey Rebellion', aggravated suspicion toward the societies up to the point of outright hostility. ${ }^{47}$ The rebellion, seemingly spreading unchecked came to a climax in mid-July 1794 when 7,000 protesters assembled east of Pittsburgh. It impelled President Washington to send an army of 13,000 militiamen to crush the rebels, an army almost the size of the Continental Army he had under his command at the time of the American Revolutionary War. It was the largest mobilization of national troops against the largest local armed resistance movement against federal law between the revolutionary wars of independence and the Civil War.

The Whiskey Rebellion gave the Federalist fears about the societies' socially disruptive potential immediate urgency and provided them with a sharpened set of argumentative weapons to attack the societies' conception of radical democratic citizenship. In December 1794, Robert Treat Paine Jr's Boston Federal Orrery, for example, after lashing out at the 'despotism of Jacobin Clubs in France', maintained that the Whiskey Rebellion was an act of defiance to constituted government analogous to Jacobin rioting. It was 'sacredly true' to his 
mind, 'that the Jacobin clubs of Paris' did nothing but 'oppose the constituted authority of the French Republic'. The American democratic-republican societies, he went on, '[n]ot being able to succeed in Congress, as their brother Jacobins did in the convention in Paris, have excited an insurrection in Pennsylvania:48 In the Columbian Centinel, one of the leading Federalist newspapers of the day, another critic depicted them as '[a]ssociations of discontented ambitious men, assembling under the disguise of night in taverns and private houses, with a pretence of redressing grievances' ${ }^{9} 9$ Their alleged secrecy was often associated with the partisan 'undemocratic' nature of French political clubs, as another 'American citizen' in a Massachusetts newspaper held. For 'how these private societies (separated in their proceedings as they commonly are, by bolts and bars, from the knowledge of their fellow citizens, without the suffrages of their countrymen as their basis, and in no way accountable to them for their conduct) how these come by their influence, or whence they derive their existence, we know not'. Clearly ' $\mathrm{t}]$ he benevolent heart must turn indignant from the sight, and our Democratic Societies themselves, would, I hope, shudder at the thought of introducing such scenes in America, as have been the fruits of Jacobinism in France.' ${ }^{50}$

The association of the democratic-republican societies with both the Whiskey Rebellion and the Jacobin clubs in France - and by implication, the Terror - became a powerful charge against unbridled citizen political activism. Noah Webster's The Revolution in France, considered in Respect to its Progress and Effects, published in 1794, was perhaps the most elaborate analysis of what he considered the violent derailment of the French Revolution. He urged his readers to take the lessons of the French excesses to heart, for 'The revolution of France, like that of Rome, is fruitful in lessons of instruction' and 'may be of great use to the United States of America.'. ${ }^{51}$ One crucial lesson the New Yorkbased editor of the American Minerva drew from the recent history of France, was the inherent danger of political clubs, those 'private societies of men, who are self-created, unknown to the laws of the country, private in their proceedings, and perhaps violent in their passions'. Such secluded political associations could only lead to 'party spirit' and 'faction'. And faction, Webster believed,

$48 \quad$ Federal Orrery (Boston, Massachusetts), December 25, 1794.

49 Columbian Centinel (Boston, Massachusetts), August 30, 1794.

$50 \quad$ Greenfield Gazette (Greenfield, Massachusetts), September 18, 25, 1794.

$5^{1} \quad$ [N. Webster], The Revolution in France, considered in Respect to its Progress and Effects. By an American (New York, N.Y.: G. Bunce, 1794), pp. 40-41. 
means ultimately 'death to the existing government. The history of the Jacobins is the most remarkable illustration of this truth., ${ }^{52}$

According to Federalists such as Webster, politics ought to be the business of eminent gentlemen who should stay clear from the swings of public passion. Looking at France, the eradication of aristocratic and noble titles was without question justified. But that titles of 'civility and respect' such as 'monsieur' and 'madame' were to be subject to legislation and substituted for the 'awkward term citizen' was a grave sign in Webster's estimation. In 'their zeal for equalizing men, the Convention forgot that certain kinds of inequality between men are, in fact, most natural in a civil society', most importantly, the kind of inequality that arises out of 'the merit of eminent services, age, talents, wealth, education, virtue'.53 'Such inequality is generally a most visible aspect of distinction in public life', and hence commands a kind of respect that in turn brings forth a 'natural aristocracy' of men of influence. 'Experience and severe calamities', on the other hand, have shown 'that government immediately in the hands of the people, of citizens collected without law, and proceeding without order, is the most violent, irregular, capricious and dangerous species of despotism'. The recent French experiment with popular democracy showed 'that a Paris mob is not to govern France'. Representative government itself had become a travesty, for an assembly of representatives ought not to be 'a company of stage-players, whose speeches are to be regulated by the hisses and acclamations of a promiscuous collection of men in the galleries. ${ }^{4}$ Another Federalist publicist, William Willcocks, projected Webster's analysis of Jacobin clubs onto the activities of 'our democrats'. 'Their professed object', Willcocks opined in a piece that appeared in the Federal Orrery and the American Minerva, is to 'censure, or applaud, correct, and control the measures of the legal representatives of the commonwealth - in other words to make parties in congress and throughout the state'. Democrats had already started to 'artfully [...] affiliate members of congress', Willcocks warned, and if no measures were taken, it would not take long, given the activitities of the 'mother society' in Philadelphia, to 'see the effects of mobs and the dreadful machinations of seditious, or ambitious men.' 55

52 [Webster], The Revolution in France, pp. 41, 47-48. Cf. The Minerva (New York, New York), November 27, 1794: '[T] he Jacobin Society has been the central point of union for the mentigers who have torn the Republic in pieces, and the vermin that gnawed upon its vital during the reign of Robespierre'.

53 [Webster], The Revolution in France, pp. 27-28.

54 [Webster], The Revolution in France, pp. 70-71.

55 Federal Orrery (Boston, Massachusetts), March 23, 1795. 
That the democratic-republican societies were associated with the Whiskey Rebellion and Jacobin practices was not entirely without grounds. The Democratic Society of Pennsylvania was a declared opponent of excise taxes. Another local western Philadelphian popular society filed petitions on behalf of discontented western Pennsylvanian settlers, an act which in the midst of a national crisis was easily dismissed as treason. ${ }^{56}$ The rebels, moreover, dubbed by the Gazette of the United States as 'sans culottes of Pittsburgh', were known to praise the example of France and set up guillotines. ${ }^{57}$ In early 1795, the Boston democratic-republican society declared that 'if to advocate the right of Free Inquiry and Opinion, and to wish success to the cause of equal Liberty every where, compose the character of Jacobins, we avow ourselves JACOBINs', while the Charleston Democratic Club petitioned in Paris to become a member of the French Jacobin Club. ${ }^{58}$ For a while, it seemed to many Federalists, democratic-republican societies sought to plunge the United States in chaotic depths similar to those of revolutionary France.

Eventually, democratic-republican societies were not able to withstand the Federalist counterattack, especially once they were condemned by President Washington whose popularity still exerted a powerful influence. About the Whiskey Rebellion, there was no doubt on President Washington's mind: 'I consider this insurrection as the first formidable fruit of the Democratic Societies'. If not counteracted, these societies were able to 'shake the government to its foundation', Washington wrote in a letter to Virginia governor Henry Lee, and 'destroy the best fabric of human government and happiness'.59 In a September 1794 proclamation on the Whiskey Rebellion, Washington publicly denounced 'certain self-created' societies. The allegations of Federalists did not pass unchallenged. Several spokesmen of the democratic societies publicly disassociated themselves from 'means unwarrantable and unconstitutional' or expressed to 'feel sore at the imputation that the insurrection in Pennsylvania is ascribable to the Jacobin Clubs. ${ }^{\prime 0}$ But it could not prevent that arguments against them, and in a broader sense against popular democracy or 'mob rule', could be fruitfully deployed by inserting the spectre of Jacobin radicalism into these allegations. In the end, the democratic-republican societies succumbed

$5^{6} \quad$ Slaughter, The Whiskey Rebellion, pp. 161-164.

57 Wood, Empire of Liberty, pp. 187-188.

58 As cited in: Wilentz, The Rise of American Democracy, p. 56.

59 Letter from George Washington to Henry Lee, August 26, 1794, in: The George Washington Papers at the Library of Congress 1741-1799, ed. John C. Fitzpatrick, available at: http:// lcweb2.loc.gov/ammem/gwhtml/gwhome.html (date of access: December 19, 2013).

6o Dunlap and Claypoole's American Daily Advertiser (Philadelphia, Pennsylvania), December 12, 1794; Andrews's Western Star (Stockbridge, Massachusetts), October 28, 1794. 
to the association with the Whiskey Rebellion, the torrent of public attacks, the dissociation of Republican leaders, and internal division. By 1796 most societies had dissolved.

The rise of democratic-republican societies, the egalitarian and participatory citizenship model they represented and propagated, and their public identification with the principles of revolutionary movements in Europe, was surely a moment of transatlantic convergence. At the same time, the writings of Federalists such as Robert Treat Paine Jr., Willcocks, and Webster were part of a broader Federalist effort to defend a model of deferential, passive citizenship, a model that bears striking similarities to the French Thermidorian model of citizenship. ${ }^{61}$ Both were grounded in a concept of an undivided citizenry. As an open letter 'to the Democratic Society of Philadelphia' that appeared in the Columbian Centinel and American Minerva in May 1794 put it: '[I]n Ameri$c a$, where there is but one order [...] the people - what use can there be in a small club of these same people? The great body of people in America constitutes one immense popular society'.62 Their model was, furthermore, premised on the high ideal of the 'independent', impartial, citizen. As Webster explained, when people become member of a political club, 'they lose their individual independence of mind [...] they lose their impartiality of thinking and acting; and become the dupes of other men. The moment a man is attached to a club, his mind is not free: He receives a biass from the opinions of the party'. The problem was not the existence of private associations as such: 'Private associations of men for the purposes of promoting arts, sciences, benevolence or charity are very laudable, and have been found beneficial in all countries'. But this is where Webster and many other Federalists drew the line. The great danger lies in the politicization of such societies. Then the 'private attachment' of their members is converted 'into an instrument of political warfare'; then 'an independent freeman is converted into a mere walking machine, a convenient engine of party leaders'.63

Finally, the Thermidorian and Federalist conceptions of citizenship in a modern republic entailed that, outside elections, citizens ought not to interfere with the representatives' 'free agency', as the Federal Orrery put it. This was 'the essential privilege of their constituents to give them - and their bounden right and duty to maintain and exercise. ${ }^{64}$ For both Federalists and Thermidorians, the Jacobin and democratic-republican societies constituted unconstitutional

\footnotetext{
$61 \quad$ See Chapter 4.

62 Columbian Centinel (Boston, Massachusetts), May 2, 1794.

63 [Webster], The Revolution in France, pp. 47-50.

64 Federal Orrery (Boston, Massachusetts), March 23, 1795.
} 
platforms of citizen activism and unsound forms of public will formation. They divided the body of citizens, conceived as a unified whole, instead of representing it, and prevented wise legislators to rule independently.

\section{Anti-Jacobinism and the American Citizenship Model}

During the second half of the 1790 s, and in particular during the period 1798 1800, American discourse surrounding the Terror took on new dimensions, as the political climate grew increasingly antagonistic. One of the key factors that accounts for this growing hostility was the souring relationship between the French and American republics, and its repercussions for domestic public temperament. Particularly explosive in this context was the so-called 'XYZ Affair'. When in May-June 1797 the United States and France almost got into a naval war, the American administration under President John Adams sent a diplomatic envoy to start negotiations with the French Directory's foreign minister Talleyrand. Judging from the documents disclosed by Adams in April the next year, the American diplomats had been humiliated and threatened by French representatives of Talleyrand (referred to in the documents as ' $\mathrm{X}$ ', ' $\mathrm{Y}$ ', and ' $\mathrm{Z}$ '), who had demanded for outstanding debt payments, bribes, and forced loans to the French Directory. Pro-French Republicans, both moderate and more democratic, were put in a particularly awkward predicament, as one of the French representatives had referred to the 'friends of France', suggesting that there was a subversive group of Americans supporting France and undermining the American government from within. The extensive reporting of newspapers on the XYZ Affair caused a national public outrage and led to a massive rallying behind the Federalist administration. ${ }^{65}$ On their return, the American diplomats were welcomed as heroes. Once popular French songs were despised and exchanged for 'Hail Columbia' and Robert Treat Paine Jr's immensely popular 'Adams and Liberty'. President Adams himself received hundreds of supportive petitions drawn by meetings from all over the country, including southern Republican states, asking for stern measures against France. As historian Douglas Bradburn has demonstrated, these petitions articulated a powerful anti-French, nationalist sentiment. ${ }^{66}$ The Federalist press,

65 M.R. Hale, "Many who wandered in the darkness": The Contest over American National Identity, 1795-1798', Early American Studies 1 (2003), pp. 127-175; T.M. Ray, “Not One Cent for Tribute": The Public Addresses and American Popular Reaction to the XYZ Affair, 17981799', Journal of the Early Republic 3 (1983), pp. 389-412.

Bradburn, The Citizenship Revolution, pp. 150-162. 
moreover, buzzed with rumours that French spies, together with American collaborators, were cooking up plans to turn the United States into a puppet republic, just as France had subjected the Dutch, Italian, and Swiss republics. When Congress issued a quasi-war declaration against France, the United States entered a state of war-like mobilization. In some towns voluntary progovernment militias began to march the streets. Occasionally, fights between democratic Republicans and anti-French crowds broke out. For a while, Republicans seemed to have lost the public's favour. ${ }^{67}$

Arguably, the XYZ Affair and the quasi-war with France only represented a temporary political blowback for (Jeffersonian) Republicans. The deeper and more permanent significance of French-American hostilities was that it proved to Federalists, as well as a to growing numbers of Republicans, that France could no longer be considered a 'benevolent sister republic'.

The polarization between Republicans and Federalists took on even more extreme forms when the threat of war with France motivated Congress in the summer of 1798 to pass four acts known as the Alien and Sedition Acts. These acts severely restricted the naturalization of foreigners, as well as the rights of non-naturalized immigrants. It was the last act that enflamed Republican publicists most, as it made punishable by law 'false, scandalous and malicious writing or writings against the United States [...] with intent to defame the said government $[\ldots]$ or to excite [...] the hatred of the good people of the United States'. ${ }^{68}$ While Federalists saw in it a means to protect the country from seditious 'Jacobin' democratic editors and publicists who tried to stir up opposition, and in their worst fantasies, overthrow civil government, Republicans widely decried the acts as a blatant violation of the constitution and as an antirepublican attack against the freedom of the press. ${ }^{69}$

On a cultural, intellectual, and also conceptual level, the distancing of Americans from the 'French' model of political order and citizenship was also due to a number of other factors. First of all, after the fall of Robespierre more and more detailed information about the Terror - although often extremely biased and hardly accurate - reached the United States and found its way into American newspapers. ${ }^{70}$ Numerous accounts of the Terror from both France and other European countries were translated and brought on the American

\footnotetext{
67 Ray, “Not One Cent for Tribute”: The Public Addresses'; Wood, Empire of Liberty, pp. 239-247.

68 'Appendix. The Alien and Sedition Laws', in: Smith, Freedom's Fetters, pp. 435-442, at p. 442.

69 Bradburn, The Citizenship Revolution, pp. 168-205.

$70 \quad$ Albany Gazette (Albany, New York), March 20, 1795.
} 
market. ${ }^{71}$ To these reports about the Terror, Federalist editors and printers eagerly supplied their comments that American citizens should by now be convinced of the 'infernal' nature of the French regime. The American Minerva of November 27, 1794, for example, told its readers that 'we have waited patiently for authentic proofs, which it was certain the experience of France would furnish, of all the tyrannies, the villaines, and the crimes which the Jacobins have, for two years past, been committing in that fine country'. The American Minerva underscored that ' $\mathrm{w}$ ] $\mathrm{e}$ always applauded the revolution' and 'admired the spirit that actuated the real republican of France'. However, given the news from France, it was important to make a 'distinction, which is certainly just, between the regeneration of the government of France, an object desirable to all good men' and 'the factious violent means of conducting the revolution'. According to the New York newspaper, it all added up to the 'evidence of the state of anarchy that has prevailed in France, and the tyranny of the popular leaders.' 72

In addition, from 1795 onwards conservative American clergymen increasingly represented and interpreted the Jacobin regime, and the French Revolution more generally, as dangerously irreligious. Reports of dechristianization and the cult of the Supreme Being were taken as signs that French Jacobins were waging a war not only on civil liberties, but on the very religious foundation of moral and political order. The publication of Thomas Paine's Age of Reason in 1794 (part I) and 1795 (Part II) had alarmed the American, and especially the New England clergy. The Age of Reason saw as many as seventeen editions in the United States, and found a broad readership among democratic Republicans, deists, and students. ${ }^{73}$ It incited dozens of heated responses from

71 Such as P.E. Béraud, The Siege of Lyons (During the Dictatorship of Robespierre), trans. From the French (Stockbridge, MA: Loring Andrews, 1795); H. Riouff, Revolutionary Justice Displayed; or an Inside View of the Various Prisons of Paris, under the Government of Robespierre and the Jacobins. Taken Principally from the Journals of the Prisoners Themselves, trans. from the French (Philadelphia, PA: 1796). See Cleves, The Reign of Terror in America, p. 87 .

72 American Minerva (New York, New York), November 27, 1794.

73 Gary Nash also mentions a number of other translated unorthodox deistic and naturalistic writings that were published in ${ }^{1795^{-1}}{ }^{1796}$, such as Constantin François de Chassebœuf, comte de Volney's Common sense; or Natural Ideas Opposed to Supernatural (New York, s.n., 1795); idem, The Law of Nature, or Principles of Morality, deduced from the Physical Constitution of Mankind and the Universe (Philadelphia, PA: Stephens and Baily, 1796); Paul von Holbach's Christianity Unveiled; being, an Examination of the Principles and Effects of the Christian Religion (New York: Columbian Press, 1795); William Godwin, Enquiry Concerning Political Justice (Philadelphia, PA: Bioren and Madan, 1796); and Voltaire's Philosophical Dictionary (New York: J. Fellows \& E. Duyckinsk, 1796). Nash, 'The American 
the conservative clergy who were anxious that Painite deism would spread among the lower ranks of society. The effect was that in a short period of time, influential clergymen heaped together Jacobinism, transatlantic Painite radicalism, and atheism (or deism), as presenting one colossal threat to the moral and political order at the time. ${ }^{74}$ Federalist newspapers eagerly joined their ranks. A telling example of how Federalist newspapers tried to mark Jacobins as godless anarchists was the satirical 'Jacobin Creed' that appeared in at least seven (national and local) newspapers in New Hampshire, Massachusetts, Pennsylvania and, South Carolina, in the summer and fall of 1796 . According to the piece, Jacobins

believe there is no God but nature; not religion but revolution (alias regeneration;) no just government but anarchy; and no civil liberty where the guillotine is not erected.

believe Robespierre was the great apostle of liberty

believe that war is better than peace, confusion than order, terror than mildness, and the guillotine than all the courts of justice extant.

believe that the United States of American ought to be under the direction of my brothers in France ${ }^{75}$

Such depictions of 'Jacobins' were not strictly comments on the Terror. Rather, the Terror was presented as part, or rather the apex, of a broader antiEnlightenment critique. This critique was not pointed against the Enlightenment per se - many Federalists identified themselves as heirs to a 'pragmatic' Enlightenment associated with such people as Benjamin Franklin - but rather against its specific French deistic (or atheistic) variant. ${ }^{76}$ The 'Jacobin' was the antithesis of the ideal of the American citizen: God-fearing and law-abiding; a supporter of order and civil liberties, and on his guard against cosmopolitan radicals united in secretive societies. ${ }^{77}$

Clergy and the French Revolution', pp. 392-412; H.F. May, The Enlightenment in America (New York: Oxford University Press, 1976), pp. 226, 263-264.

74 May, The Enlightenment in America, pp. 252-277.

75 The New Hampshire and Vermont Journal: Or, The Farmer's Weekly Museum (Walpole, New Hampshire), July 12, 1796; Gazette of the United States (Philadelphia, Pennsylvania), July 21, 1796; Eagle (Hanover, New Hampshire), July 25, 1796; Carlisle Gazette (Carlisle, Pennsylvania), August 3, 1796; Herald or, the New Daily Advertiser (Charleston, South Carolina), 8 August, 1796; Sun (Dover, New Hampshire), September 28, 1796; Rural Repository (Leominster, Massachusetts), October 13, 1796.

76 May, The Enlightenment in America, pp. 252-270.

77 Cf. Smelser, 'The Jacobin Phrenzy'. 
As public opinion was turning against France and conservative clerics were caught up in a battle against atheism, a wave of (mostly British) anti-Jacobin conspiracy literature flooded the country. The Edinburgh philosophy professor John Robison's Proofs of a Conspiracy against all the Religions and Governments of Europe, the French Jesuit Abbé Barruel's Memoirs Illustrating the History of Jacobinism, and the Scottish political economist William Playfair's History of Jacobinism attracted a large reading public and were soon embraced and exploited by the conservative American clergy. ${ }^{78}$

These works shared a number of broad characteristics. They related of the existence of a transatlantic conspiracy of Masonic Illuminati stretching back to Bavaria in the $1770 \mathrm{~s}$ in which French philosophes and politicians figured prominently. Next, the Terror was presented as the logical outcome of the atheistic philosophy professed by a network of secret societies. More frightening still, the Jacobin tentacles reached deeply into American society. No one was more important in voicing and disseminating anti-Jacobinism in the late $1790 \mathrm{~s}$ than the British publicist, printer, and bookseller William Cobbett. Under the pseudonym 'Peter Porcupine', Cobbett between 1795 and 1797 published a number of vitriolic pamphlets against 'American Jacobins', many of which went through multiple editions, with such telling titles as $A$ Bone to gnaw for the Democrats. A History of American Jacobins, or The Bloody Buoy, thrown out as a Warning to the Political Pilots of all Nations. Or, a Faithful Relation of a Multitude of Acts of Horrid Barbarity, such as the Eye never witnessed, the Tongue never expressed, or the Imagination conceived, until the Commencement of the French Revolution. In March 1797, Cobbett began his own Porcupine's Gazette in which he continued his attacks against democratic newspapers editors. Porcupine's Gazette soon became one of the most-read newspapers of the country and would be often excerpted by Federalist newspapers. Finally, Cobbett owned a bookshop in the centre of Philadelphia from where he would distribute and reprint bestselling titles including Robison's Proofs of a Conspiracy, Barruel's Memoirs, and Playfair's History of Jacobinism, as well as Aufrere's Cannibal's Progress relating of the atrocities committed during the French invasion of German states. By 1798, Cobbett was by far the most notorious anti-Jacobin

78 J. Robison, Proofs of a Conspiracy against all the Religions and Governments of Europe (Philadelphia, PA: Dobson and Cobbet, 1798); Abbé Barruel, Memoirs Illustrating the History of Jacobinism (Hartford, CO: Hudson \& Goodwin, 1799); W. Playfair, The History of Jacobinism: Its Crimes, Cruelties and Perfidies: Comprising an Inquiry into the Manner of Disseminating, under the Appearance of Philosophy and Virtue, Principles which are Equally Subversive of Order, Virtue, Religion, Liberty and Happiness; with an Appendix by Peter Porcupine, Containing a History of the American Jacobins, commonly denominated Democrats (Philadelphia, PA: W. Cobbett, 1796). 
voice in the American Republic, extremely popular among Federalists, despised by Republicans, also as the enemy-you-love-to-hate. ${ }^{79}$ Although some historians have portrayed Cobbett as an ultra-Tory and a British maverick, remaining largely outside serious political debate, more recently it has been argued that 'Cobbett's anti-Jacobinism had a profound impact on American politics. ${ }^{80}$ Well versed in the art of often biting (and sometimes comical) political satire, Cobbett's rhetoric was often hyperbolic. He also managed to alienate himself from more mainstream Federalists, because of his unashamedly proBritish stance and his attacks on other major Federalist newspaper editors, including Noah Webster and Benjamin Russell. Central, if toned-down, elements of his extreme anti-Jacobinism, however, became part of mainstream Federalist rhetoric as expressed by publicists such as Robert Treat Paine Jr. and the Federalist religious establishment.

The apex of Federalist clerical anti-Jacobinism, echoing Cobbett's rhetoric, was a sermon delivered by Jedidiah Morse, a Congregational minister from Massachusetts, in the Spring of 1798. Citing and summarizing Robison and Barruel, Morse drew an explicit connection between international Jacobin conspiracies, and 'men among us, so lost to every principle of religion, morality, and even common decency' who 'endeavoured to destroy the confidence of the people in the constituted authorities' and 'fomented insurrections among us'. What made indictments like Morse's especially suggestive was that he drew a systematic connection between the democratic-republican societies, 'the affiliated Jacobin Societies in this country', and what he called the 'astonishing increase of irreligion' ${ }^{81}$ According to historian Rachel Hope Cleves, Morse's sermons inspired many other ministers as well as politicians to focus attention on Illuminati who had only one purpose: "To root out and abolish Christianity, and overturn all civil government. ${ }^{82}$ Reverend Timothy Dwight, President of Yale College, for example, equally building on, and explicitly mentioning, Barruel and Robison, held the French philosophes responsible for breeding atheism. In addition, he held democratic printers in the United States responsible for the dissemination of 'irreligion' and sedition by sending around books and

79 Based on rough calculations, Marcus Daniel thinks that it is plausible that Cobbett sold about 200,000 copies of his own pamphlets between 1794 and 1800, an extraordinary number at the time. The opposition he aroused was so serious that Cobbett was both threatened and prosecuted for seditious libel. Daniel, Scandal \& Civility, pp. 225-230.

8o Daniel, Scandal \& Civility, p. 199; Cotlar, Tom Paine's America, pp. 97-101.

81 J. Morse, A Sermon, Delivered at the New North Church in Boston..., May gth, 1798 (Boston, MA: S. Hall, 1798), pp. 12-24. He delivered a similar sermon to an audience in Charlestown.

82 Cleves, The Reign of Terror in America, p. 91. Morse, A Sermon, p. 21. 
cheap writings. Dwight furthermore elaborated in detail on the massacres in Lyon and Nantes (even mentioning notorious Montagnard radicals such as Collot d'Herbois and Carrier). To prevent such scenes from happening in the United States, Dwight called for the 'harmonious and cheerful co-operation of the citizens'. ${ }^{83}$ Federalist voices such as Dwight's, thus, articulated a particular vision of American citizenship: law-abiding, and obedient to God and (Federalist) government.

These systematic attacks on democrats and the Jeffersonian opposition were combined with the relentless efforts to associate the activities of democratic-republican societies with a supposedly international Jacobin conspiracy responsible for the Terror at a time when the American Republic was caught up in a war with France. They helped to create a climate in which it was almost impossible for Republicans to publicly endorse a transatlantic position and defend the universalistic ideals that were once thought to be shared by Americans and French citizens alike. The Federalist rejection of transatlantic cosmopolitan notions of citizenship already implied an extensive nationalization in comparison to the universalism of 1789-1791. As an 'Enemy to Traitors' wrote in the Federalist Gazette of the United States: 'I am a citizen of the world, said a philosopher. Very well, - so am I. But I am not so much a citizen of the world as to forget that I am a citizen of the United States [...] When we carry our universal citizenship so far as to throw ourselves on the mercy of the world, we shall smart for it' ${ }^{\prime} 4$

To an important extent, this citizenship discourse was shaped by describing what American citizenship was not. Contemplating the meaning of the 'American cockade', a symbol appropriated by Federalists in the 1790 s as counter symbol to the French cockades often worn by democratic Republicans to express their sympathy with France, the Federalist newspaper Salem Gazette of September 7,1798 explained:

The American cockade is now generally worn by those, who would not prefer some other name, than that of American. What does a person who assumes a cockade profess and undertake? He professes himself to owe allegiance to the country, whose characteristics he bears. [...] That he is a friend to the constitution. [...] That no foreign governments can swerve

83 T. Dwight, The Duty of Americans, at the Present Crisis, illustrated in a Discourse preached on the Fourth of July, 1798 (New Haven, CO: Gree, 1798). Dwight also wrote the well-known poem Triumph of Infidelity (1788).

84 American Mercury (Hartford, Connecticut), July 12, 1798. Also cited in Cotlar, Tom Paine's America, p. 98. Cotlar cites the Gazette of the United States (Philadelphia, Pennsylvania), July 2,1798 . 
him from the duties of citizenship. That he is peculiarly, exclusively, and habitually, in his thoughts, actions, hopes, fears, an American' .[...] I say, to the world, that I am an American, that I will demean myself as such, that I am no jacobin, no Frenchman. ${ }^{85}$

But as anti-French sentiments ran rampant, the anti-Jacobin rhetoric of the New England clergy took on hysterical overtones. Anti-sedition laws breaded extreme discontent, and democratic Republicans began to search for resources to combat the Federalist accusations. One crucial and often overlooked turning point in the Republican discourse of the late 1790s was that Republicans started to use anti-Jacobin rhetoric against the Federalists; a rhetoric, as historian Marcus Daniel has put it, that 'exploited rather than challenged popular discontent with France and popular disillusionment with the French Revolution': ${ }^{86}$ The Alien and Sedition Acts backlashed against the Federalists as they generated the founding of many more oppositional Republican newspapers throughout the country instead of curbing them. ${ }^{87}$ Reversing the Federalist accusations of Jacobinism proved to be a convenient stick to beat the Federalist dog.

An expanding network of Republican newspapers, as well as Republican politicians in Congress and state legislatures began to describe the Alien and Sedition Acts in terms with which they had been bombarded for years. ${ }^{88} \mathrm{An}$ 'Address of the Minority of the House of Representatives of the State of Vermont, to their constituents', printed in the Albany Register in January 1799, stated that 'when the freedom of the press is restricted by federal law' $[. .$.$] the$ reign of terror agitates our state'.89 A letter to the 'Republicans of New York', published in the Republican New York newspaper Argus on the August 1, maintained that it can no longer be doubted 'that it is the intention of the federalists to introduce into this country, the system of Jacobinism'. The accusations addressed to the Federalists actually strongly resemble the language Federalists had been using since $1794^{-1795}$ to condemn democratic-republican societies. Federalist fanatics, according to the letter in the Argus, were involved in writing slanderous 'anonymous' letters and 'midnight insults and riots', Moreover, 'sanguinary and abominable publications daily issue from the press of Porcupine and other ministerial prints'; and Republican congressmen were being

85 Salem Gazette (Salem, Massachusetts) September 7, 1798. The article was reprinted in Russell's Gazette. Commercial and Political (Boston, Massachusetts), September 17, 1798.

86 Daniel, Scandal \& Civility, p. 255.

87 Pasley, 'The Tyranny of Printers', pp. 153-175.

88 Cf. Daniel, Scandal \& Civility, p. 255; Cleves, The Reign of Terror in America, p. 93.

89 Albany Register (Albany, New York), January 4, 1799. 
'insulted at a late hour of every night', and 'his family and the whole neighbourhood [were] disturbed by indecencies, which would have disgraced the sansculottes of Paris, even in the time of Robespierre'. Exposing members of the national legislature to such scenes signified 'the end to liberty and law' and raised the spectre of being 'governed by a mob'. Significantly, the letter was followed by an excerpt from Cato's Letters (a body of early eighteenth-century essays by the British writers John Trenchard and Thomas Gordon) on the freedom of thought and speech in particular, suggesting that Republicans were the guardians of an (Anglo-Saxon) intellectual tradition of free speech with which so many Americans were familiar. ${ }^{90}$

Republican publicists also began to actively disassociate themselves from the French Revolution. 'The French have done wrong!' exclaimed an article in the same Argus, a newspaper that for years had been among the most enthusiastic democratic-republican supporters of French revolutionary principles:

does it therefore follow that the politics of 'the Federalists' have been right?' Or, that the Republicans, the Democrats, the Patriots, the AntiFederalists, or whatever you please to call them, are a disorganizing Jacobin French faction, under the direction and control of French influence? [...] No! The conduct of the Republicans holds forth a very different language [...] It shows the Republicans to be what they have all along proclaimed themselves, the firm supporters of our constitution and independence, against the unlawful aggressions of any foreign power, and if possible, against all internal intrigues. ${ }^{91}$

The Boston Independent Chronicle also addressed the Federalist efforts to blacken the Republicans, describing them in a framework of reference that escaped no one: 'The rumor of a conspiracy was an essential part of that system of terror and alarm which your party have adopted. ${ }^{92}$ A county meeting of a number of Virginia 'Freeholders' complained that opponents of the Alien and Sedition Laws had been 'stigmatized as the enemies of the United States, and the partizans of France'. They pleaded 'that they will be among the first to resist the invaders of their country' and 'confidently aver that they despise and

9o $\operatorname{Argus}$ (New York, New York), August 1, 1798.

91 Argus (New York, New York), April 19, 1798.

92 The Independent Chronicle and the Universal Advertiser (Boston, Massachusetts), January 14, 1799 . 
hate sedition, riot, and insurrection, and condemn calumnies against individuals or the government. ${ }^{\prime 3}$

Republicans were thus able to appropriate tropes of order and attachment to the constitution, tropes that had belonged to the Federalist's rhetorical toolbox for most of the 179os. Philadelphia democrats in early July 1798 now toasted on 'The Constitution of the United States - may it be protected against unconstitutional laws, the fatal effects of a system of alarm, and the reign of terror. ${ }^{94}$ There was arguably some opportunism at play in appropriating this highly effective rhetorical means, but it was nonetheless an important step away from French and transatlantic radicalism. It meant, moreover, that Republicans could present themselves as moderate, and civil 'friends of order'. The Anglo-American Painite Thomas Cooper, who had become a prominent Republican journalist in the late 179os, during the state elections campaigns of Pennsylvania in 1799 presented the 'Republican party' as 'attached to representative Constitution', 'averse to war', 'careful of people's lives, and frugal of the people's money' ${ }^{55}$ This was a language employed by Republicans decidedly 'more reasonable and less frenetic', in the words of historian Michael Durey, than ever before.

Republicans not only appropriated anti-Jacobin rhetoric, they also turned away from 'French' principles more generally. The writings of the lawyer, former secretary of the Democratic Society of New York, and Democratic publicist Tunis Wortman, can be seen as an expression of this development. ${ }^{96}$ A prominent supporter of Jefferson's bid for the presidential elections in 1800, Wortman wrote a passionate defence of Jefferson against charges of atheism made by his political opponents. ${ }^{97}$ An important element of his strategy consisted of disassociating Jefferson from French philosophy and atheism:

I am not a friend to the empty fripperies, and badinage, and extravagancies of modern philosophy, nor am I an advocate of the excesses and abuses of that revolution which now convulses France, and astonishes the civilized world [...] I love my own government, because I see in it a

93 The Centinel of Freedom (Newark, New Jersey), January 15, 1799.

94 'A Number of Members of Congress', Time Piece, 16 July, 1798. As cited in: Cleves, p. 93.

95 Aurora, 11 September, 1799, as cited in: Durey, Transatlantic Radicals and the Early American Republic, p. 253. Cooper had been responsible in early 1791 for the abridged popular version of Paine's Rights of Man and migrated to the United States in August 1793 together with Joseph Priestly. Durey, Transatlantic Radicals and the Early American Republic, pp. $3^{2-36 .}$

96 On Wortman, see Young, The Democratic Republicans of New York, pp. 394, 520, 523.

97 Buel, Securing the Revolution, pp. 231-233. 
liberal, rational and practicable form, not springing up by accident, like a mushroom in the night, but growing out of the habits, manners and ancient institutions of the people [...] I know not how it happens that French and American liberty have been confounded: they have scarcely a common attribute. The liberty and religion of Washington is not the liberty and religion of Marat and Robespierre, and Anarchalis [sic] Cloots, that flaming 'orator of the human race'. I make these observations, because some [...] have endeavoured to trace a resemblance between French and American liberty. I abjure and renounce and anathematize all affiliation with the bacchanalian liberty of the great republic. [...] I love and admire that sober and rational liberty which exists in America. ${ }^{98}$

Wortman's turn away from 'the great republic' is noteworthy. In May 1796, in an oration delivered at New York's Tammany Society, Wortman had articulated one of the primary expressions of what Seth Cotlar has called 'popular cosmopolitanism' ${ }^{99}$ Whereas in 1796 Wortman invoked the transatlantic community of political thinkers, including Godwin, Paine and Priestly, and pleaded for the universal sameness and malleability of the human mind, he now put his hopes for the future on the American government and on American liberty. Certainly, the national reorientation of progressive Jeffersonian democrats such as Wortman did not imply a turn away from emancipatory ideals. Wortman's writings on liberty of the press rank among the most impressive of the time. ${ }^{100}$ But at the beginning of the nineteenth century, both Federalists and Jeffersonian Republicans distanced themselves, and the ways in which they imagined American citizenship, from transatlantic radicalism and Painite cosmopolitanism.

After 1800, in the build-up to the presidential election, Republican publicists not only actively distanced themselves from the French Revolution, some also began to strike a more pacifying chord, indeed a tone of national reconciliation. As a letter in one of the leading national Republican newspapers, the Boston Independent Chronicle, put it in late December 180o:

98 Timoleon [Tunis Wortman], A Solemn Address to Christians and Patriots (New York: D. Denniston, 180o), A Solemn Address to Christians and Patriots (New York: D. Denniston, 180o), in: E. Sandoz, (ed.) Political Sermons of the American Founding Era: 1730-1805, 2 vols. (Indianapolis, IN: Liberty Fund, 1998), vol 2., p. 1496.

99 Cotlar, Tom Paine's America, pp. 49-81.

100 R.W.T. Martin, Government by Dissent:Protest, Resistance, and Radical Democratic Thought in the Early American Republic (New York: New York University Press, 2013), pp. 157-167. 
What, and who are Jacobins? And who are Federalists? Are they not members of the same family, and connected by a common interest? Are there not on both sides men of virtues, of piety, and of talents? [...] Why then keep up these mutual recriminations? [...] Then will a spirit of urbanity, philanthrophy [sic], and patriotism succeed that of discord and contention, and brotherly love, accompanied by peace and tranquillity, will again bless our realm. ${ }^{101}$

Accordingly, Republicans could present themselves as the defenders of the legacy of the American Revolution, as the guardians of the constitution and free speech, as reasonable critics of paranoia, conspiracy thinking, and arbitrary arrests, and finally as a neutral party of peace, associated with neither the French nor the British. In this process they nationalized or Americanized their understanding of citizenship. In his inaugural address on March 4, 1801, the newly elected President Thomas Jefferson gave the most famous expression of this nationalized civic discourse. Externally, the United States were 'Kindly separated by nature and a wide ocean from the exterminating havoc of one quarter of the globe'. Internally he called for unity: 'Let us, then, fellow-citizens, unite with one heart and one mind'. Seeking to bury a decade of contestation and partisanship in which Jefferson had taken no small part, he summoned: 'We have called by different names brethren of the same principle. We are all Republicans, we are all Federalists.'102

The nationalized civic discourse that was, thus, forged during and in the aftermath of a tumultuous decade was a far cry away from the moments of transatlantic convergence of citizenship ideals of the early 1790s. Many Republicans, especially those active in, or sympathetic to, the democratic-republican societies of $1793^{-1795}$ had endorsed a transatlantic outlook for much longer. Partly because it was an oppositional discourse behind which those who were dissatisfied with Federalist could rally. More deferential and distinctly antiJacobin models of citizenship articulated by Federalists - although they hardly recognized this as such - bore striking similarities to those conceptions of citizenship as propounded by French Thermidorians in 1794-1795. This FederalistThermidorian parallelism was not the result of transfer, but can be explained by the similarity in their framework of reference which was to an important extent shaped by the Terror, and crucially, how and in what kind of political circumstances they thought the Terror had taken place. By the end of the 179os,

\footnotetext{
101 The Independent Chronicle and the Universal Advertiser (Boston, Massachusetts), December 25,1800 .

102 PTJ, vol. 33, pp. 148-152.
} 
Jeffersonian Republicans articulated their vision of citizenship in more distinctively American terms, dissociating themselves from the transatlantic revolutionary citizenship discourse, from civil discord, from Jacobin insurrection, and from French irreligion. Although it lacked a legal definition of national citizenship, the constitution - the American nature of which Republicans now emphasized - was a central element in this model as guarantee against arbitrary persecution and safeguard for the freedom of speech. The next chapter deals with the question how in the Dutch Republic ideas of citizenship were reconsidered in light of the Terror, and shows that the nationalization and moderation of the American citizenship discourse in reaction to the convulsive 1790 s was not a unique phenomenon in the Atlantic world. We will see that in the Dutch Republic, this process had a dynamic, rhythm, and character of its own. 


\section{Forging the Batavian Citizen in a Post-Terror Revolution}

Reflecting upon the 'anarchic reign of terror', the August 25, 1796 issue of $D e$ democraten (The Democrats), the leading and theoretically most sophisticated political journal of the Batavian Revolution, called attention to 'the emphatic lesson in the history of the French, expressed through the blood of so many philosophers and Patriots'. This lesson, the journal urged, must be a 'signpost to the friends of true freedom, political order, and civil security'. ${ }^{1}$ Most Batavian revolutionaries at the time, as well as Orangists, for that matter, would probably have concurred with the journal's word of advice. Over the course of the 1790s, for many publicists and politicians, including the main contributor and co-editor-in-chief of De democraten, Willem Anthonie Ockerse, the Terror came to serve as an important reference point in political debates about the future architecture and political form of the newly founded Batavian Republic. Many of those who reflected on the Terror still held on to the Ciceronian view of history as Magistra Vitae, the teacher of life. Like so many American citizens on the other side of the Atlantic, they came to view the radicalization of the French Revolution, and the violent chapter of the Terror in particular, as history in the making, indeed, as a recent history that held many lessons in store. ${ }^{2}$

The circumstances in which the Dutch reflected upon the outbreak of the French Revolution, its radicalization, and its resort to terror, however, were very different from those in the early American republic. Even if, as we have seen, there was widespread disagreement and intense conflict among Americans about the accomplishments, or, conversely, the unfinished business, of their revolution, the early American republic of the 1790s was still a postrevolutionary society in ways that the Dutch Republic clearly was not. In the late 1780s, the Dutch Republic witnessed the crushing of the democraticrepublican Patriot Movement (that had drawn inspiration from the American Revolution), and the restoration of the oligarchic Orangist regime of Stadholder

1 De democraten, vol. 1, no. 11, August 25, 1796, pp. 81-88, at p. 82.

2 By many the study of history was still seen as capable of providing lessons, even when the Terror was then 'contemporary' history, situated on the same historical plane. R. Koselleck, 'Historia Magistra Vitae. Über die Auflösung des Topos im Horizont neuzeitlich bewegter Geschichte', in: idem, Vergangene Zukunft, pp. 38-67. Cf. P. Fritzsche, Stranded in the Present. Modern Time and the Melancholy of History (Cambridge, MA: Harvard University Press, 2010). 
Willem V. The Batavian Revolution only broke out in early 1795, after the downfall of Robespierre and the Jacobin regime. The overthrow of the Orangist regime of Stadholder Willem V was made possible by Thermidorian France and executed by a combined army of Patriot exiles and French soldiers. The Batavian Revolution was a post-Terror revolution inspired by the very same revolution that had slid into terror.

The framework in which Dutch public debate about the radicalization of the French Revolution took place during the 1790 s was, thus, marked by a decisive rupture, the revolution of 1795 . One consequence of the overthrow of the Orangist regime was the brushing aside - at least for the time being - of the Orangist regime as a viable political model. A second, related implication of the new political reality was that the central ideological conflict in the public sphere was no longer played out between Orangists and revolutionaries. Instead, the gravitational centre of public debate shifted toward the differences of opinion about the future institutions of a new republic among Batavian revolutionaries themselves.

Another major difference between the American and Dutch contexts was that the Batavian experiment took place under the umbrella of the French Revolution. Over the past four decades or so, historians have rightly stressed the considerable extent to which Batavian revolutionaries could operate autonomously; the Dutch never simply served their apprenticeship in the art of revolution with French revolutionaries. ${ }^{3}$ Yet the French physical and intellectual presence was incontestably more intense in the Dutch than in the American republic. Under the Treaty of The Hague signed in May 1795, the Batavian Republic was obliged to pay France the astronomical amount of 100 million guilders as indemnity payments and to provide France with ships and troops. A secret clause required the Dutch to station and maintain 25,00o French troops on their soil, an army bigger than General George Washington ever commanded. Although the 1795 alliance treaty ensured French recognition of

3 Until the political breakthrough of January 22, 1798, forced by a group of radical republicans, and the subsequent acceptance of the constitution that established a unitary centralized state a few months later, the French kept a relatively low profile. After the second coup d'état of June 1798, and particularly after Napoleon's seizure of power on November 9, 1799, however, the Dutch increasingly lost room for political manoeuvre. In 1801, the French installed a more authoritarian and docile regime resembling the French Directoire, which in turn was replaced in 1805 by a single-headed regime under raadpensionaris (Grand Pensionary) Rutger-Jan Schimmelpenninck. A year later, Napoleon Bonaparte bluntly turned the Dutch Republic into a kingdom to be ruled by his brother, king Louis Napoleon. The Netherlands entirely lost their national sovereignty with their annexation in Napoleon's Empire in 1810, only to gain independence again after Napoleon's defeat in the Battle of Leipzig in late 1813. 
the Batavian Republic's independence, their military proximity strengthened the impression that the French could not be unambiguously hailed as liberators nor could their model be followed uncritically. From the beginning the Batavian revolution was coloured by the Jacobin experience. ${ }^{4}$

A crucially important explanation of the Terror that surfaced time and again pointed to France's lack of a sound constitutional order. This analysis became instrumental within democratic-unitarist arguments in favour of drawing up a national constitution for the new Batavian Republic. ${ }^{5}$ Its constitutional embedding came to be regarded as pivotal to citizenship. Whether the centralized unitary state established by the constitution of May 1, 1798, and its underlying ideals, was an authentic Dutch product of long-term internal developments or French import has long preoccupied the Dutch and international historiography of the Batavian Republic. However, this is in a sense a question mal posée. After all, Batavian revolutionaries realized from the very beginning that the mother republic had bequeathed an ambiguous example to them. Both for French Thermidorians and Batavian revolutionaries, the legacy of the French Revolution was troubled, not uniform. In the language of the time, the French Revolution was both a 'college of patriotism and revolutionary education', as the Dutch publicist Gerrit Paape famously put it, and a 'college of revolutionary disaster', as the former Patriot exile and representative Johan Huber declared. ${ }^{6}$ An unreflective import of French ideals was never an option.

The Terror came to be described as a typically 'French' phenomenon that had to do with the national character of the French people. Many Batavian revolutionaries were in agreement that something like the Terror was not to be expected in the Batavian Republic - and in fact, had not taken place. There was therefore no reason to follow the 'French' institutional and political response to the Terror. Accordingly, the Terror was set apart from the Dutch revolutionary experience. What was needed instead was a constitution for the Dutch and a Dutch model of citizenship.

4 Students of Dutch (both Orangist and Batavian) political thought of the 1790 s have generally neglected this question, or have only mentioned Dutch reflections on the Terror fragmentarily. See however, E.O.G. Haitsma Mulier, 'De receptie van de Franse Revolutie in Nederland. Contemporaine reactie en geschiedschrijving', Tijdschrift voor Geschiedenis 102 (1989), pp. 451-470; J. Oddens, Pioniers in schaduwbeeld: het eerste parlement van Nederland 1796-1798 (Nijmegen: Vantilt, 2012), pp. 126-128, 265-270.

5 Note that 'unitarist' in this context means favoring a unitary, centralized state. It has nothing to do with the theological doctrine of Unitarianism.

6 G. Paape, De onverbloemde geschiedenis van het Bataafsch Patriottismus van deszelfs begin (1782) tot op den 12 Junij 1798 toe (Delft: M. Roelofswaart, 1798), p. 123; Dagverhaal 4, no. 368, February 9, 1797 (session February 6), p. 793. 
This chapter, thus, clarifies the process through which the concept of citizenship became 'nationalized' during the Batavian Revolution. According to Niek van Sas, one of the leading experts of the period, the Batavian revolution's political construct of the Dutch national citizen was the culmination of a process of cultural nation formation that took place in the second half of the eighteenth century. 1798 was 'the political consequence of a process of cultural unification that had been going on for decades under the banner of the Dutch Enlightenment.' ${ }^{7}$ Van Sas has argued that after a short, but intense period of revolutionary radicalism and profound political conflict in 1798 , a clearly identifiable phase of moderation and national reconciliation set in after June 1798 . Without denying the importance of the cultural and enlightened national identity formation of the decades preceding the Batavian Revolution, and the reconciliation of partisanship after the 1798 coups, I suggest another axis along which one can discern the articulation of a concept of citizenship in national terms. More specifically, I argue that the twofold response of Batavian revolutionaries to the Terror - incorporating its lessons versus setting the Terror apart as something peculiarly 'French' - contributed to the conceptualization of citizenship in national terms. ${ }^{8}$

By situating the Batavian Republic more firmly within a transatlantic context, this chapter thus reconsiders the relationship between the Batavian Revolution and the wider transatlantic 'age of the democratic revolution'. Yet, my perspective differs from both Palmer's model of conceptual unity and Jourdan's more pluralist model in which processes of transfer play an important part. Instead, I trace and emphasize the changing character of the sense of Dutch revolutionaries of being part of a transatlantic movement in terms of a dynamical historical process of convergence and divergence. This was neither simply a question of French import nor purely a result of autonomous, domestic processes. In what follows, I stress that the Terror was an important element in the Batavian framework of reference. The evaluations generated by the Terror paralleled reflections on the Terror in France and the United States. However, if the Batavian revolutionaries shared a similar conceptual horizon with the French and Americans and were confronted with similar problems, the specific ways in which the Terror was invoked and reflected upon was determined by the phase and agenda of their own revolution as well as by the

7 Van Sas, De metamorphose van Nederland, p. 42.

8 This way of looking at nationalization is not incompatible with Van Sas's account. In fact, Van Sas sometimes hints at nationalization in opposition to the French, but not in any systematic way. Van Sas, De metamorfose van Nederland, pp. 30-31. 
national institutional and political-cultural background against which their revolution took place.

\section{Portraying the Terror between Orangist Restoration and Batavian Revolution}

Before we turn to the representation of the Terror in Dutch media, pamphlets, and journals, a few remarks on the political landscape of the late 1780 s and early 1790 are in order. The restoration of the Orangist regime headed by Stadholder Prince Willem V of Orange in September-October 1787 had involved violent punishments, the plundering of thousands of houses, and molestations of members of the Patriot Movement carried out by supporters of the Orangist regime. The States-General, provincial state, and city councils, but also lower echelons of the civil service, were purged from Patriot influences. Although no killings occurred, this 'Orangist Terror', as historian Joost Rosendaal has called it, was instrumental for the take-off of the stream of refugees in 1787-1788. Around 5,00o refugees fled to the Southern Netherlands, then under the rule of the Austrian-Habsburg Emperor Josef II, either as pit stop to northern France and Paris, or as a permanent place of exile. Ironically, instead of securing a stable power base, the unchecked ransacking and violence, as well as the processes and purges that accompanied the Orangist restoration, alienated many Dutch citizens from the restored regime. ${ }^{9}$

The conditions in the Dutch Republic for an open and public debate about the French Revolution were quite different from those in the United States. Under the Orangist regime restored by the intervention of Prussian armies in 1787 there was, first of all, no liberty of press. The Patriots who had decided to stay in the Dutch Republic had gone underground. The highly politicized Patriot journals that had mushroomed in the period $1780-1787$ and had revolutionized the Dutch (periodical) press were banned. Although after some time a general amnesty was granted to former Patriots, many editors and writers were exempted from it. ${ }^{10}$ Nonetheless, Orangist censorship was far from watertight. It was simply impossible to prevent the circulation of writings from Patriot refugees in France and foreign presses through a multitude of

9 Geyl, Geschiedenis Van De Nederlandse Stam, vol. 3, pp. 183-200; J. Rosendaal, Bataven! Nederlandse vluchtelingen in Frankrijk 1787-1795 (Nijmegen: Vantilt, 2003), pp. 33-54.

10 N.C.F. van Sas, 'The Netherlands, 1750-1813', in: H. Barker and S. Burrows (eds.) Press, Politics and the Public Sphere in Europe and North America, 1760-1820 (Cambridge: Cambridge University Press, 2002), pp. 48-68; Rosendaal, Bataven!, pp. 50-54. 
correspondence networks ran by the Patriot underground movement. ${ }^{11}$ In 1789 , for example, an abridged address of the abbé Sieyès on the Rights of Man and Citizen could be published unhindered in one of the leading Dutch spectatorial magazines. ${ }^{12}$ As the Orangist restoration rested on a precarious political foundation, and a widespread need for some kind of reform was felt throughout society, even by urban and provincial ruling elites of Orangist stripe, brutal repression was also unfeasible. The outbreak of the French Revolution, as well as the Brabant Revolution of $1789^{-1790}$, did much to stir up the flickering hope among former Patriots that the path of reform taken in the Patriot Era could and would ultimately lead to a major political transformation. The spectacular developments in France unmistakably proved the viability of Patriot aspirations. What was once considered a petty local movement, easily crushed by a highly professional Prussian army, suddenly seemed to have been part of a larger transnational revolution, a revolution that could now be resumed with the help of revolutionary France. Just like American citizens who after 1789 could reinterpret their own revolution, so the cause of former Dutch patriots was elevated, at least in their political imagination, to partake in a grand affair of world-historical importance.

Although press coverage in Dutch newspapers and journals of the various events of the French Revolution was remarkably detailed, it did not meet with widespread response or elicit strong opinions between 1789 and $1792 .{ }^{13} \mathrm{~A}$ turning point was August-September 1792, when the French constitutional monarchy was terminated, the September massacres took place, the battle of Valmy was won, and the French Republic inaugurated. Conservative commentators soon inferred that the revolution in France had taken a sinister turn. In midSeptember 1792, the Dutch 's-Gravenhaagsche Courant (The Hague Daily), a widely read, fairly pro-Orangist newspaper, suggested that with the king being suspended it is 'the rabble which at present rules despotically and decides on life and death. Commenting on the massacres that took place in and around Parisian prisons in early September, the reporter lamented that 'thinking about all the terrible horrors which have taken place in this state and the capital in

11 Schama, Patriots and Liberators, pp. 141-142; Haitsma Mulier, 'De receptie van de Franse Revolutie'.

12 Bijdragen tot het menschelijk geluk II, no. VI (1789) pp. 420-426. According to the editor, it had already appeared in the Vaderlandsche Bibliotheek van Wetenschap, Kunst, en Smaak I, no. 8, p. 353. The address in question was Sieyès' Préliminaires de la Constitution: Reconnaissance et exposition raisonnée des droits de l'homme et du citoyen, 20 et 21 juillet 1789, Comité de Constitution.

13 W. Frijhoff, M. Jongedijk, and R. Rottier, 'Vryheid of de Dood'. La Révolution française vue des Pays-Bas, 1789-1798 (Amsterdam: Maison Descartes, 1789), p. 18. 
particular makes one's hair stand on end'. The same week, a Haarlem newspaper reported that 'the streets, especially in the vicinity of the prisons, are covered with mutilated corpses'.14

Dutch responses to the increasingly violent and radical character of the French Revolution appeared at a precarious moment for the Dutch Republic. On February 1, 1793, France declared war to the Dutch Republic. By the end of February, French troops under command of General Dumouriez had seized Breda in Brabant, preparing to march on to Dordrecht. They were, however, quickly driven back by Austrian troops. By late March, the French did not pose a direct threat to the Orangist regime anymore, at least for the time being. But the threat of invasion - or prospect of liberation - and the unpredictable and chaotic course of events in France provoked a stream of publications from different sides.

One category within this stream of publications were very partisan booklets, some instructive, some more poetic, as well as children manuals and almanacs. In the richly illustrated Dutch booklet De gruwel der verwoestingen of Vrankryks moord- en treur-toneel (The Horror of the Ruins of France's Theatre of Murder and Grievance), for example, which was intended as a 'warning and spectre for all peoples of Europe', but especially for 'Dutch inhabitants', a bleak image was painted of what the author described as 'French Liberty and Jacobin Equality'. The explicit motivation behind the booklet was the publication earlier that year of an 'almanac' containing four poems commemorating scenes of the French Revolution and the military campaign into the Southern Netherlands led by the French 'citizen-general' Charles-François Dumouriez. In the pro-revolutionary almanac, the 'brave' French people were described as having been suppressed by nobility and clergy for too long, the abolishment of the monarchy as comparable to the Dutch Revolt against the Spanish king, and Dumoriez as a courageous leader, his portrait embellished with pictures of battle scenes and people dancing around the freedom pole. ${ }^{15}$ De gruwel der verwoestingen was meant as a visual counteroffensive against this dangerous pro-revolutionary propaganda. The popular siege of the royal palace and the prison massacres were construed along the narrative of a revolution in moral and political decay. While the earlier storming of the Bastille was still described in affirmative terms, even as an 'act of heroism', the theme that dominated the

14 s'-Gravenhaagsche Courant, September 12, 1792; Haarlemse Courant, September 15, 1792. Both cited in:J.W. Berkelbach van der Sprenkel, 'De Franse Revolutie in de contemporaine Hollandsche Couranten', De Gids 103 (1939), pp. 323-357, at p. 349.

15 Gedenkwaardige brieventas almanach voor het jaar MDCCXCIII (n.p., 1793), Streekarchief Midden-Holland, ref. nr. 0200.630. 
booklet's pages was mob violence and atrocities committed in dark moments of popular rage and anarchy. Almost every visual representation of the events of the Revolution contained seething crowds or acts of mob violence. ${ }^{16}$ Yet, like many American in the early 179os, Dutch commentators were simply astounded by the course of events in France. Even within the bleakest pages of this expressive piece of visual anti-revolutionary rhetoric the authors confessed that 'No one familiar with the nature of the French people' - the 'people of vive le roi' - could have 'imagined from the principles of revolution that things would rise to such great heights.' ${ }^{17}$

Dutch patriots at home supporting the French Revolution felt that they could not remain silent about the reports of violence from France. They faced the challenge of carrying through a 'radical' revolution without being associated with the 'radical' French Jacobins. Pieter Paulus, in his 1793 Treatise on Equality that would become the most important and influential treatise of the Batavian Revolution, the bulk of which was written in 1791, devoted an extensive footnote (written in late 1792) to the 'misfortunes' of France in which he acknowledged that the revolution in France was by now incontestably 'tarnished. Tellingly, Paulus blamed the calamities in rather imprecise terms on the inability of the French king and the National Assembly to collectively devise a stable form of government based on the rights of man. ${ }^{18}$

Another early example of a future revolutionary responding to the increasingly violent character of the French Revolution was Ockerse, an eccentric clergyman who in $1786-87$ had supported the Patriot Movement (if more in word than in deed), and would become the leading Batavian revolutionary of the first coup and constitution of 1798. Inspired by the revolution in France, in the early 1790 os Ockerse openly declared that he was in favour of a drastic political reform of the Orangist regime. A vehement pamphlet from his pen appeared in 1793 entitled De Constitutie der Franschen verdedigd tegen de lasterlijke grondbeginsels van de leden der Sociëteit in de Kroon en het Anker te Londen vergaderende (The French Constitution defended against the Slanderous Founding Principles of the Members of the Society Meeting in the Crown and Anchor in London), written in response to the founding manifesto of the London based Association for the Preservation of Liberty and Property against

16 De gruwel der verwoestingen, of Vrankryks moord- en treur-tooneel: Ter eeuwiger gedachtenis vertoond in een aantal fraaije afbeeldingen en naauwkeurige verhaalen van de voornaamste gebeurtenissen, geduurende de jongste revolutie in het ongelukkig Vrankryk voorgevallen. Ten leer- en schrikbeeld voor alle volken van Europa, en inzonderheid voor Neêrlands ingezeetenen (Amsterdam: J. Peppelenbos, 1794), pp. 6, 15.

17 De gruwel der verwoestingen, pp. 121-122.

18 Paulus, Verhandeling over de vrage, p. 153. 
Republicans and Levellers. ${ }^{19}$ The intended purpose of Ockerse's pamphlet was a refutation of what he called the Society's 'declaration of war' against 'the giant of Liberty and Equality' (i.e. the French Republic). ${ }^{20}$ This notorious manifesto, he noted, had caused quite a stir in government gazettes as well as ordinary newspapers 'both within and outside England'. With his own pen 'dipped neither in the gall of Anchor and Crown nor in that of the Jacobin mind', Ockerse conceded that 'the civilized French nation for some time now has degenerated into Cannibals, possess neither fairness nor faith, and solely preys on blood and tears.'21 There was no denying that the gloomy succession of disastrous events had cost thousands of lives. 'Surely not one European people, how heavily oppressed, how deeply humiliated, how cruelly mistreated, would even for a moment have reason to wish that something of that nature would take place in his country.'22 That said, there was equally no doubt on his mind that recorded history had never seen a revolution without bloodshed. To Ockerse it did not seem all that surprising to see a revolution go hand in hand with such 'convulsions' in a country that, after all, 'for more than a century has been ravaged by the scourges of an infernal despotism. ${ }^{23}$ In the end, the only people to be really blamed for the revolutionary bloodshed were, according to Ockerse, the French Bourbon kings and those who under their reign had 'corrupted' the French state. Against the background of decades of slavish subordination, it was quite understandable that the people would succumb to excesses, even more so since the revolution was thwarted by 'growing opposition' and other 'obstacles', as well as 'internal treason', threats of 'foreign violence', and 'counterrevolution'. ${ }^{24}$ Summing up these mitigating circumstances served to make one point crystal clear: the excesses of the French Revolution were not a result of the principles of the French constitution as the Crown and Anchor clique had suggested, but an aberration due to various other circumstances.

19 The London based 'Association for the Preservation of Liberty and Property against Republicans and Levellers' was founded on November 20, 1792, by the civil servant and legal scholar John Reeves (1752-1829) and had its meetings in the Crown and Anchor tavern. On this association, see H.T. Dickinson, 'Popular Conservatism and Militant Loyalism, 1789-1815', in: idem (ed.) Britain and the French Revolution, 1789-1815 (Basingstoke: Macmillan, 1989), pp. 103-126; M. Philp, 'Vulgar Conservatism, 1792/3', in: idem, Reforming Ideas in Britain. Politics and Language in the Shadow of the French Revolution, 1789-1815 (Cambridge: Cambridge University Press, 2014), pp. 40-70. van de leden der Sociëteit In de Kroon en het Anker te Londen vergaderende (z.p., 1793), p. 3. [W.A. Ockerse], De Constitutie der Franschen, p. 21.

22 Ibid., p. 37.

23 Ibid., p. 38.

24 Ibid., pp. 39-40. 
Yet, news of the ensuing violence and chaos in France made even the most fervent Dutch supporters of democratic reform feel uneasy. Among them was Samuel Wiselius, regarded by many historians as one of the driving intellectual forces behind the reformulation of the Patriot - into the Batavian - political agenda in the early $1790{ }^{25}{ }^{25}$ Between 1789 (at the age of twenty) and 1793 he delivered three bold lectures in front of bustling audiences at the Amsterdam based heavily politicized literary society Doctrina \& Amicitia. This society has rightly been described as the 'intellectual centre of the Patriot Movement, from whence the Batavian Revolution of 1795 would largely be prepared' ${ }^{26}$ In his lecture Proeve over de verschillende regeringsvormen in derzelver betrekking tot het maatschappelijk geluk (Treatise on the various Forms of Government in their Relation to Public Happiness) delivered in early 1793, Wiselius submitted the democratic form of government to a critical examination. The attentive listener could not fail to detect the hidden references to the situation in France. 'Absolute democracies' (volstrekte Demokratien), Wiselius said, 'are always liable to manifold ruptures and disturbances'. Only at the end of his exposition he cautiously suggested to 'cast a glance at a large neighbour nation, to...', but Wiselius broke off his sentence and continued: 'However, I don't want to engage in speculation, which, even though grounded, may give offence to some.'. ${ }^{27}$ Looking back on his lecture some three decades later, Wiselius, recalled the 'current' against him, 'being denounced so sharply' that he decided to stow away his address as it was declared 'antipopular, aristocratic, and entirely oldfashioned': ${ }^{28}$ Even within Dutch pro-revolutionary circles striking the right balance between praising the principles of the French Revolution, and disapproving of the excesses of 'absolute' democracy was a delicate business.

Finally, a number of Patriot exiles lobbying in Paris for French support for the launch of a revolution in the Dutch Republic, who would come to play a role in the Batavian Revolution, witnessed the radicalization and political violence of the French Revolution from close by. Naturally, reconciling the glorious 'cause of liberty' allegedly shared by French and American citizens, with the 'dreadful excesses' was a major challenge to them. The Catholic patriot and former mayor of Eindhoven (Staats-Brabant), Jan van Hooff, co-founder in October 1792 (together with Johan de Kock and Pierre Alexandre Dumont-Pigalle)

25 Leeb, The Ideological Origins of the Batavian Revolution, pp. 229-251; De Wit, De strijd tussen aristocratie en democratie, pp. 83-93, 319-336; Van Sas, De metamorphose van Nederland, pp. 208-281, 307-308; Velema, Republicans, p. 188.

26 De Wit, De strijd tussen aristocratie en democratie, p. 85.

27 S. Wiselius, Proeve over de verschillende regeringsvormen in derzelver betrekking tot het maatschappelijk geluk (Leiden: S. en J. Luchtmans, 1831), pp. 25, 31.

28 Wiselius, Proeve over de verschillende regeringsvormen, vii-viii. 
of the Comité Revolutionair der Bataven (Batavian Revolutionary Committee), is a case in point. As member of the Revolutionary Batavian Committee which was formally acknowledged by the French National Convention in late October 1792 and was instrumental in rallying the French behind their plan to invade the Dutch Republic, Van Hooff co-authored a manifesto that sought to prepare the Dutch mind for a regime change. However, after the defeat of the French armies against the Austrians in March 1793 and the desertion of General Dumouriez, a Girondist with whom the Batavian Revolutionary Committee had closely cooperated, the Committee was disbanded. The radicalized Jacobin faction, purged of its Girondin members, came to look upon the Batavian Committee's members with suspicion. Van Hooff, imprisoned in the former Collège des Irlandais and later in the Palais du Luxembourg, barely escaped the scaffold during the great Terror of June-July $1794 .{ }^{29}$ With the dawn of Thermidor, he was released in early November. His close associate De Kock was less fortunate and was guillotined in the purge of the Hébertists in March 1794. Perhaps not surprisingly, when Van Hooff secured a seat in the Batavian National Assembly in 1796, he would become one of the most outspoken critics of the excesses of the Jacobin regime.

At least eighteen representatives of the first National Assembly (12\%) had spent some time in the French epicentre of revolution. But only a handful of exiles - Van Beyma, Van Hooff, Valckenaer, Blok, and Bicker - held a prominent place in the National Assembly's meetings. Joris Oddens has maintained that the former exiles 'interpreted the French experience just as varied as the representatives who did not spend the [Orangist] restoration in France. ${ }^{30}$ In other words, there does not seem to be a clear correlation between the radicalism of the representatives and their sojourn in revolutionary France. Yet, as we will see, future Batavian revolutionaries such as Van Hooff drew on their own observations and experience of revolutionary politics in Paris to critically reflect on the workings of the Jacobin clubs.

As was to be expected, from the Orangist ranks the popular democratic tendencies of the French Republic were criticized in much harsher terms. Adriaan Kluit, the most prominent Orangist publicist and counterpart of Paulus at the time, in late 1793 cynically remarked about the September prison massacres that the act of 'septembriseeren' by an 'inflamed crowd' - 'that is, in the current parlance of Liberty, dragging the prisoners out of prison on the street, one by one, guilty or not guilty, and letting the people tear them apart' - was something even a malicious king had never undertaken. But the ' 500 or 600 men' of

29 Rosendaal, Bataven!, p. 420.

3o Oddens, Pioniers in schaduwbeeld, pp. 127-128. 
the new Convention that had replaced the king as the 'people's representative' were now 'applauded' for it. ${ }^{31}$

That same year the Leiden city magistrate, bibliophile, and Holland deputy for the Dutch States-General between 1793 and 1795, Johan Meerman published an anti-revolutionary tract which devoted considerable space to an analysis of course of the French Revolution. In his De burgerlyke vryheid in haare heilzaame, de volks-vryheid in haare schadelyke gevolgen voorgesteld, inzonderheid met betrekking tot dit gemeenebest (Civil Liberty with its Beneficial, Popular Liberty with its Harmful Consequences presented with Special Reference to this Commonwealth), Meerman took explicit aim at what he called 'popular or political freedom', offering a stinging critique of the democratic practices he observed in the French capital. ${ }^{32}$ Meerman's critique of popular democratic practices in France was not simply reactionary slander. On closer inspection, it articulates a line of argumentation that also resonated with French and American reflections on the Terror, even with what more moderate Batavian revolutionaries would come to argue. During meetings of the French representative assemblies, a form of 'public consultation', Meerman wrote, the 'galleries of the assembly' were 'packed with paying spectators promoting the interests of that party that filled their bellies'. These meetings were saturated with 'improper cheers and clapping', 'corrosive grumbling and laughter', and sometimes even 'death threats' addressed to representatives at the assembly hall's entrance. Ever since the first meetings of the National and Legislative assemblies, Meerman asserted, 'France has not been at liberty for one single hour'. He was especially critical of the Paris-centeredness of all political activity: 'Instead of the deputies of the entire people', it was Paris that ruled. ${ }^{33}$

Meerman singled out the political clubs as especially anti-democratic, as the decrees that were to be submitted to the 'supreme assembly' were already 'forged' in the political 'societies. ${ }^{34}$ In combination with the 'vengefulness' and 'avarice' of demagogues manipulating the public, the politics of these clubs proved to be a recipe for disaster and the cause of the continuous recurrence of 'dehumanizing scenes'. The inconstancy of the people was, moreover, displayed by the fact that where Necker and Lafayette were first hailed as heroes, they were then quickly despised as enemies of the people. ${ }^{35}$ All things

31 [Kluit], De rechten van den mensch in Vrankrijk, p. 99-100.

32 J. Meerman, De burgerlyke vryheid in haare heilzaame, de volks-vryheid in haare schadelyke gevolgen voorgesteld, inzonderheid met betrekking tot dit gemeenebest (Leiden: Luchtmans, 1793), p. 4.

33 Meerman, De burgerlyke vryheid, p. 39.

34 Ibid., p. 40.

35 Ibid., p. 41-42. 
considered, the new political system could hardly be called a genuine democracy according to Meerman. It was a political minority that ruled 'over the larger, conquered mass of silent and calm inhabitants'. The fundamental problematic concept was the citizens' newly acquired political liberty: 'Political liberty is by nature - I cannot find words to express my conviction powerfully enough - the exterminator, the eradicator, the murderer of civil [liberty]. ${ }^{36}$

What is remarkable about Meerman's attack on political liberty is that he condemned the French revolutionary government for making a travesty of the principles of transparent democratic governance and public debate. The critique he advanced was not so much anti-democratic in nature - what might be expected from an Orangist publicist. Rather, he argued that the French revolutionary government was bullied by popular clubs that were hardly transparent and in practice denied Frenchmen outside Paris equal democratic participation. At first sight, it makes sense to dismiss Meerman's 'pro-democratic' critique of the French representative democracy as a rhetorical move, an opportunistic argument well-suited for the occasion. After all, Orangist publicists in the 1780 s and 179 os were not particularly well known for their democratic sympathies. However, Meerman was fully aware that after the outbreak of the French Revolution, some degree of reform and opening up of the Dutch ruling elite was unavoidable, and to some extent desirable. In this he was not alone. In his unpublished writings, the future constitutional architect of the constitutional monarchy of 1814-1815, Gijsbert Karel van Hogendorp also criticized the poor constitutional makeup of the French Republic. ${ }^{37}$ Considered within a transatlantic context of perceptions of the Jacobin Terror, Meerman's analysis actually turns out to be very much in line with a broader post-Terror rejection of political clubs and advocacy of robust constitutional safeguards.

2

\section{Limiting Power, Protecting Rights: The Terror and the Need for a Constitution}

In mid-January 1795, French-Batavian troops crossed the great frozen rivers of the Waal and the Lek and marched north. In an unguarded moment at night, the Stadholder and his retinue hastily fled to England. Soon former patriot

\footnotetext{
$36 \quad$ Meerman, De burgerlyke vryheid, p. 42.

37 See, for instance, G.K. van Hogendorp, Gelijkheid der menschen (door Pieter Paulus) wederlegd. Een fragment denkelijk 1793. Nationaal Archief, Collectie Van Hogendorp, 2.21.006.49, Inv. nr. 71-f; G.K. van Hogendorp, Omwendingen (na de Fransche Revolutie) IIde, IIIde, en IVde hoofdstuk. Nationaal Archief, Collectie Van Hogendorp, 2.21.oo6.49, Inv. nr. 71-m.
} 
citizens in cities and towns in Utrecht and Holland deposed the sitting city councils. Although in some places, Zeeland province especially, revolutionaries met with more resistance from local governments, the regime change generally occurred without violence. By the end of February, the Statenvergaderingen (provincial councils) were replaced by provisional assemblies of representatives. The Provisional Assembly of the Representatives of Holland took on a leading role by declaring openly the 'people's sovereignty' and the 'unalienable rights of man'. On January 31, the Holland Assembly issued the first Dutch declaration of the rights of man and citizen. ${ }^{38}$

The first, chief political issue to be tackled after the overthrow of the Orangist regime in early 1795 was the formation of a national convention. The supreme political authority of the federative Dutch Republic was - on paper still the States-General, an assembly composed of representatives of the provinces that were largely autonomous. Despite swelling public opinion in favour of a new state structure based on the principle of 'één- en ondeelbaarheid' (unity and indivisibility), proposals for a national convention met with firm opposition, in particular from the side of the members of the provincial assemblies of Zeeland, Friesland, and Groningen. Various proposals advocating a unified state structure, and the formation of a national assembly to bring such a unified state about, had been worked out by Patriot exiles as early as 1789. However, on the whole these plans did not provide for a detailed plan of how the formation of a national convention should take place. If this national convention should come up with a new constitution, as most Batavian revolutionaries agreed, what should be its status prior to the eventual adoption of a new constitution? Moreover, what ought to be the nature of the mandate of the representatives that were to make up this new convention? Should they be 'independent' representatives, without 'last en ruggespraak' (instruction and obligatory consultation), representing one sovereign Dutch nation, or were the provincial assemblies to have a final say in the matter? ${ }^{39}$

In early 1795 , in what would become a controversial pamphlet, Ockerse made a passionate plea for a national convention. He explained that opponents fearing a recklessly instituted powerful and independent national convention often referred to the French example for guidance. According to these opponents, the French National Convention was the source of the 'tragedies'

38 For an analysis, see Jourdan, La Révolution batave, pp. 106-108; W.J. Goslinga, De Rechten van den Mensch en Burger: een overzicht der Nederlandsche geschriften en verklaringen (The Hague: A.J. Oranje, 1936), pp. 86-107.

39 Oddens, Pioniers in schaduwbeeld, pp. 82-100; Schama, Patriots and Liberators, pp. 211-244. 
France had suffered. Yet, the tragedies of France, Ockerse replied, had more to do with the influence of the French king, the 'agitation of the clergy', and the 'villainy of intriguers'. The reign of Terror under Robespierre was not a consequence of the transfer of political power to a national convention, but an aberration of otherwise sound principles. 'Should we reject the good in its totality, because it has been ill-used?', he asked. As France had moved beyond the Terror and taken a moderate turn, Ockerse felt he now could safely evoke the new French Thermidorian regime:

Do you not, does the Nat. Convention not have a newly approved constitution to consult? Should we not have confidence that that people, experienced through blood and tears, cleansed the constitution of all despotic influence, have offered us a model that we for the time being could follow? ${ }^{40}$

Reflecting on the dawn of a bright new phase in the French Revolution, Ockerse thus considered it to be only logical to call upon the Dutch people to demand a national convention. Whereas in 1793 Ockerse had foregrounded 'circumstances' in his explanation of the French regime's resort to methods of terror, he now conceded that the bloody experience of the French Revolution had something to do with the very constitutional make-up of France, or rather the lack of it. The Jacobin regime's lack of constitutionality, and the new air of constitutionalism under Thermidor, thus, came to be invoked in arguments in favour of drawing up a new constitution. In Ockerse's journal De democraten of August 25, 1796, this line of analysis was carried forward:

The Democratic Constitution that was adopted in 1793 affirmed by experience that which had previously been taught by political philosophers: that an extended Republic cannot exist by way of a democratic order. Yet one still has to admit that the horrors committed by Robespierre and his followers were not necessary consequences of the Constitution of 1793; this constitution was rather a result or creation of their disorderly system. ${ }^{41}$

In a later issue of De democraten it was specified that, although the Jacobin constitution of 1793 might have been designed with 'good intentions' and

\footnotetext{
40 [W.A. Ockerse], Bataven! Eischt eene Nationale Conventie! of beroep aan het Bataafsche Volk (n.p., 1795), pp. 10, 13-14.

41 De democraten, vol. 1, no. 11, August 25, 1796, pp. 81-88, at p. 82.
} 
based on 'simple philosophical grounds', it lacked 'sufficient preservatives' against the 'abuse demagogues and anarchists made of it afterwards'.42 The history lessons of the Terror could, thus, be of great help 'to stem the tide of vices, debauchery, and deficiencies that may rise again with every blow of passions, fanaticism and intrigues. ${ }^{43} \mathrm{~A}$ sound constitution could check the power of a national legislation and prevent arbitrary use of power according to Ockerse.

What is crucial to observe is that by setting apart this extreme episode of the French Revolution as an 'aberration', unitarist-democratic revolutionaries such as Ockerse could dissociate their political agenda from Jacobin radicalism. In the process, if still in general terms, they forged a post-Terror conception of citizenship around the concepts of law and order, a new constitution for a unified state, and the alleged sobriety of the Dutch. Radical democratic-unitarist revolutionaries such as Ockerse, whose passionate pamphlet incited widespread disapproval, were keen to embrace the Thermidorian moment in France. More than anything else, Thermidor and its most important spokesperson Boissy d'Anglas, whose Discourse préliminaire was avidly read and appeared in Dutch translation, represented to them France's return to constitutional government. Not only radical republicans such as Ockerse, but also more moderate revolutionaries were able to appropriate parts of Boissy d'Anglas's republican discourse for their own revolutionary agenda aimed at the establishment of a constitutional republic (although in the course of the Batavian Revolution central elements of the Thermidorian constitution came to be rejected). ${ }^{4}$

Dissociating the Batavian cause from Jacobin radical politics was, for example, also the tenor of a letter to the editor in De republikein (The Republican), the other leading political journal of the early Batavian revolution, edited by Jan Konijnenburg, a prominent journalist and professor at a remonstrant seminary of democratic-unitarist hue (although he prided his own journal to give space to opinions that were not necessarily his own). The anonymous author of the letter actually argued against those who sought to resolutely wipe the institutional slate clean and give the national convention carte blanche. The formation of a national convention was absolutely necessary in his eyes, that is, as long as it was equipped with a clear and limited mandate. Given the heated public debates and the fresh memory of the Terror, the author felt it was necessary that the more deliberate advocates of the formation of a Dutch

42 De democraten, vol. 1, no. 38, January 26, 1797, pp. 277-284, at p. 280.

43 De democraten, vol. 1, no. 11, August 25, 1796, pp. 81-88, at p. 82.

44 Cf. Oddens, Pioniers in schaduwbeeld, pp. 242-262. 
'National Assembly' shake off the reputation of being unruly revolutionaries, lest the national convention would become tainted by association with 'socalled revolutionary government'. It was this form of revolutionary government, the 'scheme hatched by the tyrant Robespierre, through which tragic France was terribly shocked and so much innocent blood was spilled.'45 Honest and upright revolutionaries, the author maintained, know how to distinguish between the moment of revolution and the moment that freedom has actually been obtained. Moreover, they know how to distinguish between the (violent) means of bringing about a revolution and the means to consolidate it. Honest and upright revolutionaries too 'are horrified by injustice, persecution, and oppression' as well as 'revengefulness' against the 'errors and political crimes of former regimes'.

Anticipating the accusation that he was 'pro-Orangist', even 'Aristocrat', the author suggested that with his reconciliatory attitude he was actually in good company. He offered a lengthy quote from the Dutch translation of Thomas Paine's Dissertation on the First Principles of Government that had been published the previous year to back up his position. ${ }^{46} \mathrm{He}$ singled out the end of the pamphlet where Paine criticized France for not having adopted a constitution soon enough, a measure that otherwise would have prevented the country from falling into chaos and violence. Paine's - and the anonymous author's message was that man's desire for freedom, including the understandable desire to punish his enemies, must be institutionally curtailed, first and foremost by a constitution. The author went on to add another lengthy quote from, again, another recently translated foreign text: the Discourse préliminaire by Boissy d'Anglas. ${ }^{47}$ 'One will learn from it', he suggested, 'that his way of thinking is of a piece with that of Thomas Payne.' Boissy d'Anglas' speech not only advised to withhold from reckoning with political opponents. According to the anonymous author, it addressed a much broader subject: Jacobin democracy and the Terror. '[I]f we do not draw lessons' from Boissy d'Anglas' speech, he asserted, 'then we must blame ourselves in the case we, although duly and thoroughly warned, run upon the rocks of anarchy, exaggerated patriotism, popular demagogy and agitation. ${ }^{\prime 4}$ Like Ockerse, moderate voices like this letter in De republikein also sought to isolate the Terror, in order to dissociate the

45 De republikein II (1796), no. 57, p. 35.

46 T. Paine, Dissertation on the First Principles of Government (London: Eaton, 1795). Translated as Verhandeling over de eerste beginsels der regeering (Leiden: Murray and Loosjes, 1795).

47 F.A. de Boissy d'Anglas, Vertoog bij de aanbieding van het ontwerp van constitutie, voor de Fransche Republiek (Haarlem: F. Bohn, 1796).

48 De republikein, II, no. 57 , p. 38 . 
broader Batavian revolutionary project from Jacobin radicalism. The embedding of their cause within a reinvented transatlantic revolutionary agenda in which Boissy d'Anglas and Paine were presented as its moderate spokesmen, shows that the redefinition of citizenship through the prism of a constitution was informed by experiences and discourses that transcended national boundaries.

For the eminent legal scholar J.H. Cras, the overarching lesson Batavian revolutionaries ought to learn from the Terror was also constitutional, but in a slightly different way than Ockerse and the opinion article in De republikein claimed. In 1795, Cras opposed the establishment of a national assembly, that is, as long as the constitutional rules this new assembly should adhere to would not be determined first. One cannot assume, he argued, that citizens would elect good representatives and that, in turn, these representatives could be trusted unconditionally. The Terror was his main point of reference. 'The French Citizens, who elected Marat, Robespierre, and his followers were acting in good faith'. They turned out to be 'monsters' who were actually 'fellow citizens of the innocent victims they murdered'. But 'they could not have murdered [them]', Cras argued, 'had there been a Constitution, which would have restricted the power of the National Convention. 49

There was some truth to that observation. Although the French National Convention had approved the new Montagnard constitution of Year I on 24 June 1793, it was never implemented. From 10 August 1792 until 26 October 1795, the day on which the Constitution of Year III was put into effect, France was effectively being ruled by exceptional, or 'revolutionary government', as the Montagnard politician Saint-Just put it, that is, outside the framework of a constitution. Cras's argument was premised on this French experience. Without a robust constitution a centralized government could easily slid into terror.

Whereas Ockerse belonged to the democratic-unitarist strand of the Batavian political spectrum, building a case for a national convention that ought to come up with a constitution as soon as possible, Cras supported a centralized government but warned for a lack of constitutional checks. Yet, other voices could be heard too. Pragmatic federalists desiring a decentralized, federative state structure, such as Jan Henrik Swildens, also elaborated at length on the 'example' of France to elucidate their conceptions of constitution and

49 [H.C. Cras], Gewigtig advys over de vraag: moet eene constitutie de Nationale conventie; of een Nationale conventie, de constitutie voorafgaan? (n.p., n.d. [1795]), pp. 6-7. 
citizenship. ${ }^{50}$ In his Politiek belang-boek voor dit provisioneel tydperk (Political Interest Book for this provisional Age) published in 1795 , Swildens, a professor of natural and constitutional law at the Franeker Hogeschool and author of a number of key political publications of the Dutch Patriot Era, also tried to detach the Batavian Revolution from the Terror and take to heart the lessons it provided with regard to the question how a gradual reform of the existing political order should proceed. The series of astonishing events that had rocked the French nation could be of great help to Dutch revolutionaries, Swildens thought, as they could now 'look back wiser' and 'look forward more cautiously'. As he saw it, France's 'manifold' revolution was now 'mourning its fatal mistakes'. The country had been ravaged by a 'thousand headed Jacobin Monstrosity'; terror had been 'the order the day'. But perhaps, he suggested, the 'foundations' of a new political order must be sought in the 'ruins of destruction. 51

He accordingly offered a 'succinct list' of recommendations, literally 'after the example of France. ${ }^{52}$ Among other things, he insisted on the importance of law and order and equality before the law, which required a pragmatic constitutional outlook: 'we must return from feigned equality, which nature neither provides nor preserves, to such equality that [...] must be provided and forever safeguarded by civil ties and law and order'. In other words, 'we must return from what is constitutionally aesthetic for either the eye or in theory, to what is constitutionally useful. ${ }^{53}$ Admittedly, Swildens' recommendations were still quite vague, even cryptic. But they were perhaps for that reason also representative of a broader tendency among Batavian revolutionaries who wished to revise the idea of revolutionary citizenship in light of the Terror. A sound constitution was the principle means to arrive at a model of post-Terror citizenship.

\section{Channelling the Participation of the People}

While there was almost unanimous support for a constitution as the principle means to prevent a reign of Terror, the question of how to channel the political involvement of the citizenry was still open. Batavian revolutionaries were all in

50 In the Dutch context, Federalists were those who supported a decentralized confederal republic, which is the complete reverse of the American Federalist.

51 [J.H. Swildens], Politiek belang-boek voor dit provisioneel tydperk (Amsterdam: J.R. Poster, 1795), pp. 33, 39, 130.

$5^{2}$ [Swildens], Politiek belang-boek, pp. 107-108.

53 [Swildens], Politiek belang-boek, p. 131 . 
favour of democratizing the political system. There was, however, a great divergence of opinions about the ways in which and to what extent this democratization should be operationalized, especially given the recent French experience. What degree and kind of political participation is desirable? And what were the dangers of involving a broad citizenry in politics? The history of the Terror in France raised fears over the role of popular societies, preventing faction, keeping the rabble in check, and dealing with the fickleness of the people.

Broadly speaking, virtually all Batavian revolutionaries were in agreement that the new Batavian Republic ought to be governed by a system of elective representation. But, as has recently been pointed out in some detail, the nature and extent of the involvement of the people in a system of political representation was vigorously contested. Inspired by Rousseau, radical (unitarist) republicans such as Pieter Vreede and Bernardus Bosch incessantly emphasized the permanent sovereignty of the people. They insisted that the task of representatives - a term some in fact wished to see substituted for 'governors' or 'administrators' so as to emphasize the executive nature of representation - consists of executing the general will of the people, not forming it. In a representative system, according to these radical republicans, citizens organized in popular societies exercise their sovereignty by continuously monitoring, admonishing, and holding their representatives accountable.$^{54}$ Although the radical republicans who put forth this conception of citizenship represented an important and vocal voice, the majority of the Batavian revolutionaries subscribed to the idea of a more independent representative body, to whom the capacity of exercising popular sovereignty was transferred..$^{55}$

In addition, it is crucial to realize that the frequent calls for citizen's (civic) vigilance and political readiness, the emphasis placed on the vital function of political clubs and societies, and the stress on the ultimate and permanent sovereignty of the people, were forms of political mobilization rhetoric at a highly uncertain revolutionary moment (if revolutionary France had made one thing clear, it was that in revolutionary times nothing is certain). The revolutionary years between 1795 and 1798 were not only theoretically, but also institutionally and politically fluid. There was no constitution yet, and the National Assembly was not an ordinary parliament but a constituante, a constituent assembly. According to the radical republicans, the Batavian Republic remained in a state of

54 W.R.E. Velema, 'Republikeinse democratie. De politieke wereld van de Bataafse Revolutie, 1795-1798', in: Grijzenhout, Velema, and Van Sas (eds.) Het Bataafse experiment, pp. 27-63, esp. pp. 46-51; Rutjes, Door gelijkheid gegrepen, pp. 77-8o. Other radical republicans advocating permanent civic participation were representatives Court Lambertus van Beyma and Jacob Hahn.

Cf. Koekkoek, "Eene waare en vrije republiek"'. 
revolution until the acceptance of a new constitution would end it. ${ }^{56}$ Politicians were forming coalitions, trying to put pressure on opponents and potential allies, and seeking public support. We should, in short, be cautious to interpret revolutionary republican rhetoric simply as programmatic statements about a post-revolutionary order.

The crux is that most Batavian Revolutionaries felt that such platforms for (revolutionary) citizen activity only had a temporary role to play. Before 1795, Wiselius, for instance, had been rather critical of the 'manifold ruptures and disturbances' in France caused by unsound democratic practices. But in the Spring of 1795, when he had been chosen as Amsterdam's representative for the Provisional Assembly of Holland, he was all too eager to invoke the help of grass-roots democratic forces. In Wiselius's estimation, the volksvergaderingen (municipal popular assemblies) of Amsterdam were the democrats' backbone against the city's conservative bulwark of patrician regents. He noted that they were 'the best support for friends of the people, for pure democrats, who aim at unity and indivisibility'. However, after January 1798, once the unification of the Dutch state was forced through, Wiselius made multiple efforts to close 'these disastrous deliberating primary assemblies. ${ }^{57}$ Revolutionaries such as Wiselius, as well as Gogel, Ockerse, and many other prominent publicists and politicians, were convinced that tranquil and learned gatherings of enlightened citizens (among whom they counted themselves) in equally cultivated premises were perfectly legitimate, and must be carefully distinguished from rowdy popular meetings in less pristine surroundings. ${ }^{58}$ Yet, as long as there was no constitution - and the possibility of a counterrevolution could not be ruled out - popular societies functioned as a powerful lever and a well of revolutionary energy. For the majority of Batavian revolutionaries, popular societies and associations were a temporary lever in times of revolution, no permanent platforms of political participation.

Moreover, after the French experience, popular societies always raised the spectre of faction. According to the former professor of theology, prominent publicist, and future Batavian national representative IJsbrand van Hamelsveld, there was a real danger to crowds, clubs, and faction. In an exposé addressed to the citizens of Leiden in March 1795 in the Reformed Marekerk and printed afterwards, Van Hamelsveld laid out his view on the means to arrive at the 'good cause of liberty'. He observed that

56 Cf. Oddens, Pioniers in schaduwbeeld, p. 199.

57 As cited in De Wit, De strijd tussen aristocratie en democratie, pp. 123, 167-168.

$5^{8}$ For a similar assessment of Wiselius and Gogel's aversion to political involvement of the lower classes, see Schama, Patriots and Liberators, p. 331. 
[f]action and parties of which France, in the middle of the great attempts of this noble nation, has given us formidable examples, are the consequences of Clubs and Societies that operate separately, that become animated by the spirit of someone who sets the tone, pretends to have special insights, and acts from distinctive principles. - No! The people is an indivisible unity, one body; without uniformity of action based on these very principles, without being aimed at the same purpose, an orderly voice of the people is impossible. ${ }^{59}$

Van Hamelsveld, just like American Federalists and French Thermidorian centrists, conceived of the role of societies and clubs in the French Revolution in terms of a shattering of the monistic, unified body of citizens. He also saw a connection with the political dynamic of crowds: 'Only with trembling and fear can I think of the dismal disorderly assembling of a crowd threatening with destruction; a tumultuous gathering is not a proper voice of the people, not an orderly activity.' Crowds, he went on, are only too easily carried away by 'popular leaders' or 'demagogues who with a glib tongue and gentle words win the people to their side. ${ }^{60}$

Yet, the evaluation of the legitimacy and role of political associations and clubs was much more ambivalent than the harsh rejection of IJsbrand van Hamelsveld appears to suggest. In 1795, a hotchpotch of hundreds of such societies existed throughout the country. Some were revolutionary committees newly founded in 1795 to support the overthrow of the old regime on a local level. Others had grown out of politicized reading societies founded in the early 1790s. And others still stretched back to the 178 os or earlier.61 Revolutionary committees set up in late 1794 promoted the establishment of more popular political 'reading societies' to cultivate and enhance revolutionary consciousness, and create a network of political allies. ${ }^{62}$ Then, again, there were ward meetings, as well as more militant clubs coming together in taverns

59 Y. van Hamelsveld, Vertoog over de middelen, tot voltooijing en handhaaving van de de goede zaak der vryheid; voorgedragen aan de burgerij van Leyden (Leiden: C. de Pecker, 1795), p. 18.

6o Van Hamelsveld, Vertoog over de middelen, p. 18.

61 On Dutch eighteenth-century cultural and literary societies, see Mijnhardt, Tot heil van 't menschdom; De Vries, Beschaven!.

62 Geyl, Geschiedenis van de Nederlandse stam, vol. 3, p. 291; P.J. Buijnsters, 'Lesegesellschaften in den Niederlanden', in: O. Dann, (ed.) Lesegesellschaften und Bürgerliche Emanzipation. Ein europäeischer Vergleich (Munich: C.H. Beck, 1981), pp. 143-158, at p. 154; H. Reitsma, 'Lesegesellschaften und Bürgerliche Revolution in Amsterdam', in: idem, pp. 159-180. See also T. Poell, The Democratic Paradox. Dutch Revolutionary Struggles over Democratisation and Centralisation (1780-1813) (Utrecht, Dissertation, 2007), pp. 91-93. 
and public houses. And finally, primary assemblies were instituted to choose representatives for local, provincial, and national political offices; they could also function as platforms for education and debate. How to distinguish between these various forms of societies and assemblies, and how they related to each other was not always clear and varied from town to town; their role and function were subjects of numerous local conflicts. ${ }^{63}$ Some of the older existing societies were initially artistic, literary, scientific, or philosophical in nature (which is not to say that all these societies became politicized). ${ }^{64}$ Members were often engaged in editing, and writing for, (spectatorial) journals and periodicals. Whereas the Patriot Era witnessed a strong politicization of a number of these journals and societies, this process was interrupted by the restoration of the Orangist regime in the late 178 os. But in the early 1790 s, societies such as Doctrina \& Amicitia, as well as many others, became the cradles for revolutionary thought, and eventually, revolutionary action.

It should come as no surprise, then, that, as in France, political associations and popular societies enjoyed a venerable reputation. Many leading Batavian revolutionaries had intellectually and politically matured in these societies. They had often served as a springboard for their political careers, as in the case of the democratic-unitarists Ockerse and Konijnenburg. ${ }^{65}$ Ockerse's De democraten promoted popular societies as vehicles of enlightened education, political engagement and patriotism, and generally as benevolent platforms for citizen activism. Citizens should be the permanent 'guardians of the constitution' and should be able to voice their criticisms in local, popular meetings so as to avoid the establishment of an 'elective aristocracy' and create a true 'democracy by representation' instead. ${ }^{66}$

The ambiguous stance on the nature and role of popular societies came to the fore in a debate in the National Assembly in June 1797. Earlier, on March 10, 1796, a majority of the representatives had decreed that the right of petition applied to individuals only, not to corporations, societies, or associations, a

63 For Amsterdam, see A. Jourdan, 'Amsterdam klem tussen staat en volk. Een bedreigde municipaliteit (1795-1798)', in: I. Nijenhuis, J. Roelevink, and R. Sluijter (eds.) De leeuw met de zeven pijlen. Het gewest in het landelijk bestuur (The Hague: ING, 2010), pp. 95-110. For Utrecht, see R.E. de Bruin, Burgers op het kussen: volkssoevereiniteit en bestuurssamenstelling in de stad Utrecht, 1795-1813 (Zutphen: Walburg Pers, 1986). On the province of Friesland: J.R. Kuiper, Een revolutie ontrafeld: politiek in Friesland 1795-1798 (Franeker: Van Wijnen, 2002).

64 Mijnhardt, Tot heil van 't Menschdom; De Vries, Beschaven!.

65 See Koekkoek, "Eene waare en vrije republiek"'.

66 De democraten, vol. 1, no. 7, August 4, 1796, 'Iets over de volks-sociëteiten', pp. 49-56; De democraten, vol. 1, no. 11, August 25, 1796, pp. 81-88, at p. 88. See also De democraten, vol. 1, no. 38 , January 26,1797 , pp. $277^{-284}$. 
decision that was prompted by fear of too assertive and potentially disturbing popular societies, and the idea that the popular will cannot and ought not to be expressed by mediating bodies. ${ }^{67}$ In June 1797 , in the build-up to the referendum on the first Ontwerp van Constitutie (draft of constitution), the leader of the radical republicans in the National Assembly, Pieter Vreede, (a former member of the heavily politicized literary Rotterdam society Studium Scientiarum Genitrix) suggested that popular societies be made permanent bodies guaranteed by the constitution. Accordingly they may become legitimate popular societies, schools in which the country's true interests will be taught, minds will be brightened, and hearts will be sparked.' He proposed to constitutionally recognize these 'depositories of freedom' and turn them into permanent platforms for citizen participation. ${ }^{68}$

Representative Jan van Hooff, who had been imprisoned in Paris during the Terror and had closely witnessed the working of the Jacobin clubs, praised Vreede's intention behind his proposal and acknowledged the need for citizens' education and enlightenment. Van Hooff considered societies as an appropriate means to that end. But he rejected Vreede's proposal for installing permanent primary assemblies, as these would bring about a 'permanently deliberating nation'. Even worse, it would 'declare war between the authorities and the people' and 'result in an eternal flow of confusion, which can only end in anarchy'. Moreover, most citizens would be too busy with their own affairs to be able to attend the society's meetings. Hence the meetings would run the risk of being dominated by 'the ambitious' and 'intriguers'. Drawing on the ideal of a monistic body of individual citizens, Van Hooff argued that popular societies ought not to be constitutionally protected because they cannot claim any 'more rights' than a 'private person'. Echoing Van Hamelsveld, he claimed that they cannot become part of the 'body politic', the 'sovereignty of the people is after all one and indivisible.' Van Hooff pointed out that in France 'the societies which assumed the right of the entire people or were affiliated with the société mère called the Jacobins, were destroyed'. They 'not only controlled the constituted authorities' but also 'rivalled with the National Convention', chasing away 'true patriots' and trying 'to destroy the national representation'. In the end most representatives agreed with Van Hooff that a permanent involvement of primary assemblies would interfere with the indivisibility of the people's sovereignty as represented in the National Assembly. ${ }^{69}$ Vreede's

67 Oddens, Pioniers in schaduwbeeld, pp. 164-165.

68 Dagverhaal 6, no. 561, June 13, 1797 (session May 26), p. 117.

69 Ibid., pp. 117-118. 
proposal was voted down. But the debate shows that the French experience with political clubs bequeathed an ambiguous legacy to ponder.

Another consequence of the Terror was that, apart from a few radical republicans, most Batavian revolutionaries invoked this violent episode as a warning for what they considered the lower, uneducated classes. Again, the revolutionary language they used - of equality and (universal) natural rights - can be deceptive here. It is crucial, however, to observe that one of the mouthpieces of radical Batavian republicanism, the journal De democraten, also uttered serious doubts concerning the fitness of certain classes of people for full political citizenship. ${ }^{70}$ If there was one thing the Terror had demonstrated, De democraten in January 1797 suggested, it was that 'the general corrupted state of humanity requires tighter curbs. ${ }^{71}$ Such precautions would especially apply to what De democraten referred to as the 'rabble, the major part of a population.' ${ }^{72}$ The journal's observation that this substantial social class usually 'adheres to the dominating party' and 'is disposed to looting and assaulting' actually seemed to contain a double reference: to the Paris mobs as well as to the marauding bands of Orangists of 1787 , the memories of which were all but forgotten among ex-Patriot Batavians. It behaves 'savagely when it is stirred', but 'trembles when confronted with some bayonets or a handful of police officers'. The 'fatherland's rabble', De democraten asserted, 'consists of a bunch of children that necessarily requires leading reins.' A sound revolution, the suggestion went, ought not to depend on them..$^{73}$ The French experience had revealed

70 Wyger Velema, and following in his footsteps, Mart Rutjes, have recently underlined the importance of the classical-republican tradition as one of the principal sources that shaped Batavian visions of citizenship, even though they point out that this 'classical' republicanism was informed by an (enlightened) egalitarian natural rights discourse. More specifically, they identify the ideal of political participation and display of disinterested civic virtue as the defining aspects of the more radical conceptions of citizenship put forth during the Batavian Revolution. My point is that the Terror threw an ominous light on the ideal of the participatory citizen and the phenomenon of popular societies as platforms for citizen activism. It brought to light the risk of involving those who were designated as the lower, uneducated classes. Even for radical Batavian republicans the ideal of active citizenship was more coloured by the Terror than Rutjes and Velema allow for. Velema, 'Republikeinse democratie'; Rutjes, Door gelijkheid gegrepen, pp. 18-21. See also Velema, Republicans, pp. 179-200.

71 De democraten, vol. 1, no. 38, January 26,1797 , pp. 277-284, at p. 280.

72 Rutjes contends that the distinction between 'people' and 'plebs' or 'citizens' and 'the rabble' disappeared completely in the period ${ }_{1795}-1801$. Although it might be true that the specific terms 'gemeen' or 'grauw' (rabble/mob), etc., were not often used, the evaluation of Batavian revolutionaries of 'the people' was much more complicated than Rutjes appears to suggest. Rutjes, Door gelijkheid gegrepen, pp. 127-128.

De democraten vol. 1, no. 38, January 26, 1797, p. 282. 
that the 'middle class' ought to be 'the support, the most useful part of any state' and that in this middle class one can find 'most honesty, most patriotism, most enlightenment'. Among them 'one can find the purest conceptions of revolution.' '[T] he happiness of the state', De democraten concluded, 'depends on this distinguished part of the people'. Yet, the journal lamented that it was in this very same class that one would 'discern little spiritedness and most lethargy'. ${ }^{74}$ Reflecting on the Jacobin regime, De democraten, thus, articulated who should be the principal bearers of modern citizenship in the Batavian Republic. Behind the declared and abstract defences of popular sovereignty and representative democracy, lay a deep suspicion of the actual involvement of the lower classes in politics.

The alleged impressionability of 'crowds' as Van Hamelsveld put it, or the 'rabble' in the words of De democraten, was shared by a considerable number of Batavian revolutionaries. Consider the theologian, Zeeland politician, and future minister of education and professor of oriental languages at Leiden University, Johannes van der Palm, who in 1795 gave an address in the Vaderlandsche Sociëteit (Patriotic Society) of Middelburg (Zeeland) on the problematic notion of 'popular favour'. After the invasion of the Batavian-French troops in January 1795, Van der Palm had swiftly worked his way up in Zeeland urban and provincial politics and became a member of several committees including the Assembly of Provisional Representatives of Zeeland in $1795^{-1796}$. Although a declared supporter of the Batavian revolution, Van der Palm was very much on his guard against what he diagnosed as the inconstancy of the public's judgment and its passionate nature. ' $[\mathrm{N}]$ othing is more ferocious and fickle than the favour of the people', he impressed his audience in 1795:

We're not the Marats, the Robespierres, whose memory has become a curse and horror, once gods worshipped by the people, who voluptuously kissed their blooded hands, and kneeled down for the disgraceful guillotine as well as for the holy altar of the Fatherland? ${ }^{75}$

As these comments by De democraten, Van Hamelsveld, Van Hooff, and Van der Palm demonstrate, the Terror had left a deep impression on them. Their fears of the manipulability of the mass, the inconstancy of popular favour, and the

74 De democraten, vol. 1, no. 38, January 26, 1797, p. 282.

75 J.H. van der Palm, Redevoering over de volksgunst. Uitgesproken te Middelburg in eene vergadering van de Vaderlandsche Sociëteit (1795)', in: J.H. van der Palm, Redevoeringen, verhandelingen en losse geschriften, 5 vols. (Leeuwarden: G.T.N. Suringar, 1854-1855), V, pp. $36-44$, at p. 38 . 
tumultuous nature of public gatherings, as well as the danger of faction caused by popular societies, were articulated in response to the revolutionary situation in the Batavian Revolution but were also informed by the French experience.

So far we have seen that the Terror became an important point of reference in debates about the constitutional embedding of citizenship, the channelling of political participation, the fear of involving the mass in politics, and the contested role of popular societies. However, in their efforts to promote popular societies as appropriate vehicles of revolutionary mobilization and education, radical republicans also sought to dispel the widespread fears of Jacobin scenes. They argued that it was simply not to be expected that Batavian popular societies would be dominated by demagogues and bring about immense disorder as had been the case in France. Certainly, the Terror had shown that the French constitution of 1793 was harnessed, as De democraten put it, with too few 'clamp springs' and 'means of coercion. ${ }^{76}$ However, the supposedly fiery 'temperament' of the French was seen as another chief cause of the excrescences of the French Revolution. Downplaying the risk that Dutch popular societies would become dominated by demagogues (as had happened in France), since the Dutch allegedly possessed a calm and quiet temperament, became a recurring argumentative strategy. Contrasting the Dutch national temperament with the French one and drawing on the bloody consequences as displayed in recent French history, was moreover not a line of argument exclusively employed by one group in particular. It was a widely shared assumption among Batavian revolutionaries. Yet, there was a variety of ways in which it was put to use. In a broader sense, emphasizing these contrasts contributed to the conception that the Dutch should arrive at their own national model of citizenship.

Thus, according to the unitarist representative Jacob van Manen, "The wellknown incontestable national character or disposition of the Dutch' is 'one of the main things one ought to take into consideration when devising a constitution.' The French served as the ultimate foil in such statements, for 'isn't ours quite the opposite of the French national character?'77 The point these representatives wished to convey was not only that the Terror was unlikely to ever happen in the Batavian Republic. They also insisted that the Dutch need not

76 De democraten, vol. 1, no. 38, January 26 , 1797 , pp. $277-284$, at p. 280.

77 Dagverhaal 3, no. 254, November 22, 1796 (session November 18), pp. 678-679. 
necessarily follow the French in their institutional response to the Terror. The dismissal of the French system came especially to the fore during a debate in early February 1797 over the question whether the legislative power should be divided over two chambers. Representative Johan Huber's proposal that the Batavians should adopt the French system of a Conceil des Anciens and a Conceil des cinq-cents, met with strong objections. Huber observed that the Dutch were lucky to have 'learned wisdom and prudence' from the French experience, the 'School of Misfortune'. The 'licentious constitution of 1793', this 'Law book of Anarchy', he argued, should never be our 'guide'. Huber then went on to praise the French constitution of 1795, advocating a two-chamber legislative system for the Batavian Republic on that basis.

Huber's characterization of the Jacobin constitution of 1793 as 'anarchical', however, did not make a strong impression: by 1797 that was a truism to most of his colleagues. But whether his implication that the Dutch, therefore, ought to adopt the French institutional response of a two-chamber legislation was justified, was quite another matter. Jacob Hahn, one of the most vocal and prominent representatives of the National Assembly, disagreed fiercely with Huber: 'It is wrong, it is disadvantageous, it is most dangerous even to invoke the constitutions of the French like that', he cried out. 'I believe it befits the representatives of the free Batavian people [...] to maintain our independence to the highest degree'. Hahn acknowledged that the French may very well be content with their own 1795 constitution, but 'we speak for The Netherlands, and for The Netherlands only! 78 Representative Herman Vitringa wholeheartedly agreed: 'the scenes in France' were of course of great value, especially the lessons they provide 'regarding the consequences of irregular desires, passions, and weaknesses'. But 'in the arrangement of their state', he pointed out, the French 'had to take into consideration reasons and circumstances that are not ours'.79 Not only was the Terror thought to be a kind of phenomenon alien to the Dutch national spirit, the very absence of this particular experience in the Dutch revolutionary process confirmed the national particularity of a reinvented Dutch republic, and the legitimacy of including in it a nationally conceived 'Dutch' model of citizenship.

This - sometimes strained - combination of intellectually incorporating the lessons of the French experience of the Terror, while simultaneously setting it apart as something peculiarly 'French', was also Ockerse's principal way of dealing with the Terror. Ockerse's earlier dismissal of the Jacobin constitution of 1793 and his praise of the Thermidorian constitution of 1795 by no

78 Dagverhaal 4, no. 369, February 10, 1797 (session February 6), pp. 797-798.

79 Ibid., pp. $798-799$. 
means implied that he thought that the latter should be automatically transposed to the Batavian Republic. If the constitution of 1795 was 'perhaps the best the French could have ever devised for themselves', as De democraten had put it in August 1796, it was quite another question whether this constitution is 'the best and most appropriate' for the 'phlegmatic Batavian nation', a nation of hardly two million people, most of whom were in trading business, and moreover, 'have been living under a republican form of government for almost two centuries'. ${ }^{80}$ The 'best' constitution, Ockerse believed, rehearsing a commonplace in political theory from Aristotle to Montesquieu, is, in short, a relative notion. Ockerse held that a constitution should be entirely adapted to the 'character' of a nation.

Ockerse's preoccupation with the 'character' of a nation was not incidental. He had developed, and was in 1796-1797 still in the process of developing, his thoughts on 'character' in a major three-volume exposition Ontwerp tot eene algemeene characterkunde (Sketch of a General Science of Character), the volumes of which were separately published in 1788,1790 , and $1797{ }^{81}$ In these works, Ockerse aimed to offer a systematic exploration of the concept of character, by which he generally understood that composition of features through which someone or something may be distinguished from something else. The scope of his investigations ranged from the character of individual human beings to social classes and professions, and from small communities such as villages and cities to larger social units, such as peoples and nations, and finally even the character of entire centuries - in particular the one he was living in. ${ }^{82}$ His expertise in this field and his commitment to this mode of sociocultural enquiry led him to examine the issue of the most appropriate constitution for the Dutch Republic comparatively and in light of recent experiences. A number of issues of the journal De democraten clearly can be seen to echo the third volume of his Ontwerp which was basically concerned with the study of national characters and came out in 1797. On the most fundamental level, Ockerse maintained (echoing Montesquieu) that national characters were formed

8o De democraten, vol. 1, no. 11, August 25, 1796, pp. 81-88, at p. 83 .

81 W.A. Ockerse, Ontwerp tot eene algemeene characterkunde, 3 vols. (Utrecht: G.T Paddenburg; Amsterdam: J. Allart, 1788-1797).

82 The first volume received several mixed reviews in Dutch magazines, as well as a twelvepage positive review in the French Journal encyclopédique (1788) and another long, mainly positive, review in the British Monthly Review (1791). For this see, J. Stouten, Willem Anthonie Ockerse (1760-1826). Leven en werk. Het bewogen leven van een verlicht 'Bataafs' politicus, letterkundige, predikant en wijsgeer en zijn veelzijdig oeuvre op de overgang van de achttiende naar de negentiende eeuw (Amsterdam: APA-Holland Universiteits Pers, 1982), pp. 69-81. 
by geographical location and climate, which entails that one can find among various nations a variety of means of subsistence, needs, facilities, and mores. One would find, then, that peoples vary in temper and passions. Around the same time that national character was discussed in relation to a new constitution in the National Assembly, Ockerse's De democraten asserted that the Frenchman is 'quick, comprehends swiftly, decides immediately', while 'his passions are easily moved'. During the recent French revolution, there were men who 'abused their [the French people] zeal with specific intentions' and 'induced the people to take rash steps' and accept 'unthoughtful decrees'. ${ }^{83}$ Ockerse went on to explain that popular mass meetings in a central 'colossal city' such as Paris, which were the centre stage of revolutionary action, were particularly attractive to fortune seekers, idlers, and demagogues. Urban crowds were accordingly prone to be carried away by passion. In contrast to the French, De democraten maintained, the Dutch nation is 'phlegmatic, calm and easily satisfied, frugal and counselling, even in times of opulence'. He attributed to the Dutch nation a 'strong craving for liberty' and a certain 'conceitedness which takes no advice'. ${ }^{84}$ Even in times of revolution, then, 'as much as the heated Frenchman must be soothed, the sluggish Dutchman must be galvanized' ${ }^{85}$ Because of this difference in national temper, Ockerse did not fear French excesses, for 'our Nation is not susceptible to tragic scenes that disgrace humanity, not susceptible to a reign of terror.'86

On the contrary, radical Batavian revolutionaries were rather impatient with the National Assembly, as negotiations over the new constitution proceeded too slowly to their liking. In late July 1797, just before the first Ontwerp van Constitutie (Draft of Constitution) would be rejected by an overwhelming majority and Dutch constitutional debates seemed to end in hopeless deadlock, Ockerse held that while 'France has provided us a warning, a powerful example of the consequences of a terrorist administration', the pendulum of French political sentiment had swung to the other extreme, that is, to a 'too exaggerated moderation'.87 The aversion to 'exaggerated' moderation even led some radical publicists, such as Pieter 't Hoen in his journal Nieuwe Post van den Neder-Rhijn to rescue and defend 'Jacobinism' against 'bitter and unjust

\footnotetext{
83 De democraten, vol. 1, no. 38, January 26 , 1797, pp. 277-284, at pp. 278-279.

84 Ibid., p. 280.

85 Ibid., p. 282.

86 De democraten, vol. 1, no. 38, January 26 , 1797, pp. 277-284, p. 283. For a comparable claim that the Dutch are not susceptible to the dangers of popular democracy as the French had been, see the letter of the Batavian constitutional committee to the French envoy Delacroix of March 5, 1798. Colenbrander, Gedenkstukken, II, pp. 190-194.

87 De democraten, vol. 2, no. 64, July 27, 1797, pp. 181-188, at p. 186.
} 
judgements'.88 Based on the fear that after two years of deliberation without any concrete results, the Batavian revolutionary fire would peter out like a damp squib, the moderate Thermidorian regime ceased to be an attractive model. In this process, the Terror and the Thermidorian reaction were turned into specifically French phenomena of the recent past. They were not considered general features or necessary phases of a revolution. Batavian revolutionaries rejected the French revolutionary 'script' ${ }^{89}$ Part of the reason for making this argument was the effort to legitimize and clear the way for revolutionary action. The isolation of, and distancing from the Terror, and more generally the emphasis on a divergence of revolutionary experiences then, contributed to the 'nationalization' of the Dutch revolution, and hence to the conceptualization of citizenship in national terms.

\section{The End of the Democratic-Republican Citizen}

Whereas until January 1798, to many the Batavian political experiment almost seemed to succumb to a lack of political decisiveness, there was no shortage of political action in the following period. Between January 1798 and October 1801, the Batavian Republic witnessed as many as three coups d'état and two constitutions. Amidst this chaos the general trend was that politicians in executive positions during these years assumed power to the detriment of the legislative branch. The 'public' - of citizens, journals, popular societies, pamphleteers - was put on the side line. Meanwhile, French pressure was building; none of the three coups would have been possible without their backing.

The immediate cause for the change in political climate was the defeat by an overwhelming majority of the first Ontwerp van Constitutie (Draft of Constitution) in a referendum held on August $8,1797 .{ }^{90}$ In the months preceding the referendum radical republicans had mounted a successful campaign against it, issuing pamphlets and making full use of the political journals and network of political societies they had at their disposal. They viewed the constitutional draft as seriously defective. Their main objection, in a nutshell, was that the

88 Nieuwe Post van den Neder-Rhijn, vol. 3, no. 149, August 29, 1797, pp. 1217-1224 at p. 1217.

$89 \quad$ K.M. Baker and D. Edelstein (eds.) Scripting Revolution. A Historical Approach to the Comparative Study of Revolutions (Stanford, CA: Stanford University Press, 2015).

9o In total 136,716 voters had cast their vote. 108,761 (79,6\%) voted against, $27,955(20,4 \%)$ voted in favour of the draft constitution. 
proposed constitution contained too littles afeguards for meaningful political participation and influence of the people. ${ }^{91}$ Just before the constitutional referendum, new elections for a second National Assembly had already been ordered. The installation of the second National Assembly in September, thus, coincided with her predecessor's failure of arriving at a constitution. Among the radical republicans, whose numbers were strengthened, and whose selfconfidence had grown after the rejection of the constitutional draft they had put so much effort into discrediting, a sense of urgency took hold that the impasse demanded unconventional measures.

On January 22, 1798, a coup d'état was executed by, among others, Konijnenburg, Ockerse, and Vreede. Crucial was the military backing of the then French envoy Charles-François Delacroix. A new constitutional committee, staffed by among others Konijnenburg and Ockerse, the committee's leading member and spokesperson, soon set to work to draft a new constitution. Theirs was more democratic, centralized, and egalitarian than the draft of 1797. It was put to the vote in a referendum on 23 April and accepted on May 1, 1798. The Staatsregeling (constitution) of 1798 replaced the old, decentralized state structure of the Dutch Republic of the seven provinces with a unitary, centralized state. It was ruled by a national parliament composed of democratically elected representatives. The individual rights of citizens, including the equal legal status of religious convictions, were laid down in the constitution. Those who qualified for full citizenship including the right to vote, that is, those who were over 20 years of age, paid taxes, had resided in the Dutch Republic for the last two years, were able to read and write in the Dutch language, and had signed a civic oath - were now citizens of a unified Dutch nation-state. ${ }^{92}$

The coup d'état, however, created more division and less national unity than ever before. Despite all their spirited talk about democratic participation in the preceding three years, the radical republicans' seizure of power was hardly a sign of their commitment to participatory citizenship. Not only the National

$91 \quad$ Velema, Republicans, p. 197.

92 Women were excluded from the right to vote, as were those who had declared an oath to a foreign power, domestic servants, the needy who relied on, or lived in, workhouses and mental institutions, wards of court, those who were bankrupt and/or in receivership, and those who were indicted by a court of law. The oath of loyalty to the Batavian Republic read: 'I hold the Batavian people to be free and independent, and promise my loyalty to it. I declare my constant aversion to the regime of the stadholder, federalism, aristocracy, and anarchy. I promise that, in all my actions, I will dutifully follow all regulations of the constitution, and never will hand over my vote to someone who I deem to be an advocate of the stadholder, a federalist regime, aristocracy, and anarchy.' 
Assembly was purged from moderate (or anti-unitarist) representatives after 22 January. On May 4 it was also decided by the (temporarily installed) Constituent Assembly that two thirds of its members would stay on in the legislative body to be formed after the newly ordered elections. In addition, in the months following January 22, primary assemblies (grondvergaderingen) were on a national scale disposed of (potential) opponents of the new democraticrepublican regime. In some places up to thirty percent of the electorate was scrapped from the voter registers and thereby deprived of their right to vote. This measure especially bred bad blood as it also implied the deprivation of the right to public office and retirement payments. Civil servants that were suspected of anti-democratic-unitarist sympathies were removed. ${ }^{93}$ Finally, primary assemblies came to be restrained by article 18 of the constitution. This article stipulated that in primary assemblies, citizens were only allowed to vote, not to discuss matters. Popular societies were furthermore denied the right to act publicly and correspond with each other (much like the Thermidorian measure against popular societies of mid-October 1794). On paper, popular societies were tolerated as long as they refrained from political activities. In reality, however, many local revolutionary committees, ward meetings, and political clubs were dismantled - and not only those opposing the new regime. ${ }^{94}$ The Friesche Courant (Friesland Courier) of February 3, 1798, announced that the future constitution 'restrains the political rights of citizens in the circle of primary assemblies, and will regulate one's means and capacity to organize in distinct societies, [and] involve oneself in politics [...] in such a way that these societies will never cause any disturbances. ${ }^{95}$ Local democratic elections for city councils, provincial assemblies (and occasionally civil servants) were eradicated and replaced by a system of assignment by the central authorities.

Through all these measures the new regime sought to secure its fragile power base. Yet, in doing so, they simultaneously undermined it. The high tide of democratic-unitarist reign was short-lived. The new government lacked a firm local power base and had antagonized many with their purge of local primary assemblies and imprisonment of political opponents. The decision that only one-third of the seats of the present Assembly would be open for re-election

93 Oddens, Pionier in schaduwbeeld, pp. 322-336.

94 Kuiper, Revolutie ontrafeld, pp. 429-437; Jourdan, 'Amsterdam klem tussen staat en volk'. In his discussion of 'Representative democracy and republican participation', Velema omits to mention the large-scale purge of, and restrictions placed on, primary assemblies, as well as the closure and restraining of popular societies after January 22. Velema, 'Republikeinse democratie'.

Friesche Courant, 3 February 1798. As cited in: Kuiper, Revolutie ontrafeld, p. 419. 
seemed even to moderate supporters of the new regime a blatant violation of their own professed constitutional principles. With the blessing of then French minister of foreign affairs Talleyrand, a second coup d'état was executed on June 12, 1798, by a motley crew of moderates, general Daendels, and some from within the very own ranks of the radical republicans of January 22. Their takeover further contributed to the disintegration of the democratic-republican infrastructure, as now the radical clubs supporting the January 22 regime were also swiftly dismantled and a significant number of political journals were censored. ${ }^{96}$ Ironically, then, the political coup of January, together with the coup of June 1798 , virtually destroyed grass-roots democratic participation, its infrastructure, and perhaps even more important, its spirit. The radical phase of the Batavian Revolution of January-May 1798, which undeniably constituted a breakthrough in Dutch constitutional and institutional history, was not the zenith of democratic-republican citizenship, but the beginning of the end of it. Those who looked upon it with disappointment, could not help to relate this domestic experience to the authoritarian course the French Revolution had taken since 1797. Oppression, violating the constitution, eliminating political opponents: the radical phase of the Batavian Revolution became identified with the French experience, and more generally, with the failure of the age of revolutions and its underlying principles.

June 1798 heralded a new phase of reconciliation, nationalization, and depoliticization. In a famous and often quoted letter of June 26 to Samuel Wiselius, Jacob Spoors, one of the foremost perpetrators of the June coup, expressed the sentiment thus: 'Our politics is entirely new [...] It is nothing else than being strictly honest, affronting all intriguers, putting into operation and nationalizing the constitution, so as to once and for sweep away all the basis for all faction. ${ }^{97}$ In fact, Spoors's claim that politics as of June 1798 would be 'entirely new' was a grave exaggeration. The constitution of May 1, after all, was left intact. The framework of nationalization and reconciliation was a centralized state structure, at least on paper. And as people were fed up with the ineffective, impotent national representation torn apart by faction and disputes, the cry for 'nationalization' could be heard everywhere.

By 1801, many politicians deemed the effectiveness of Batavian government profoundly inadequate. A third coup d'état was executed by a minority of

96 De Bruin, Burgers op het kussen, pp. 173, 186, 198-199; M. Prak, Republikeinse veelheid, democratisch enkelvoud. Sociale verandering in het revolutietijdvak, 's-Hertogenbosch 17701820 (Nijmegen: Sun, 1999), pp. 250-252.

97 Colenbrander (ed.) Gedenkstukken der Algemeene Geschiedenis van Nederland van 1795 tot 1840 , vol. 3, p. 442 . 
executive government officials. The constitution was pushed through under the pretence of a democratic referendum; the legislative body was basically dismantled; an executive council assumed all power, and the word 'republic' was dropped. The new regime of 1801 proclaimed that the new constitution was a product of 'duty, patriotism, and experience', that is to say, of the experience that 'discord, discontent, and the desire for change' had wreaked havoc. The new constitution, they argued, would make an end to this.

The new political climate of the years around 1800 also produced corresponding concepts of citizenship. Illustrative is the journal Burger politieke blixem edited by the dyed-in-the-wool patriot and revolutionary Bernardus Bosch, who was thrown out of the halls of power after the coup of June 1798. He started two weekly journals, De heer Janus-Janus zoon and Burger politieke blixem. ${ }^{98}$ The mission statement of his new Burger Politieke Blixem commenced by addressing all 'Bataven, Patriotten, Anti-Patriotten, Foederalisten', etc. ${ }^{99}$ Bosch's journal called for the prevention of 'all clashes within the constituted powers', the combining of 'mutual interests', the 'concordance of laws, the vigilance of the courts of police and justice', the promotion of 'order and duty', a resilient and clearly expressed 'will of the nation', and the 'unification of factions.'100 The French Terror 'that took place in our century in front of our eyes' remained a cardinal point of reference: 'The bloody pillars on which the French Republic rests provide us a series of terrifying consequences of popular discord and clashes within government, from which every human sentiment shiveringly recoils, but nonetheless serve as an important lesson.101 To prevent such discord and recklessness, when 'the laws remain silent', one has to realize that a people ought to governed 'according to their national character [...] according to inbred parental prejudices'. This, Bosch argued, 'is the best way to keep the balance of popular sentiment steady' and reconcile different points of view. ${ }^{102}$ By way of concluding his mission statement Bosch announced that Burger politieke blixem 'will make it its sacred duty to alert the people, and urge good citizens to perform the duties that characterize the honest, [public] interestgenerating patriot, family man, industrious husband, affectionate son [...] present in every class.'103 This language of Bosch's journal was markedly

98 On Bosch and his journals, N.C.F. van Sas, 'De Republiek voorbij. Over de transitie van republicanisme naar liberalisme', in: Grijzenhout, Velema, and Van Sas (eds.) Het Bataafse experiment, pp. 65-100, 310-313.

99 'Opdracht', in: Burger Politieke Blixem 1 (1800). The first issue appeared on April 15, 1800.

100 'Opdracht', in: Burger Politieke Blixem 1.

101 Ibid.

102 Ibid.

103 Ibid. 
different from his earlier high-spirited writings and speeches. His 'national' citizenship ideals, put in contrast with the French revolutionary experience, were no longer meant to energize a revolutionary people but intended to reach a broader Dutch audience sick of discord and faction.

In the different circumstances of 1800-1801, former radical republican revolutionaries like Bosch struck a tone of melancholy, disillusionment, and criticism, for example about the gradual return and acceptance of Orangists, in public life, discourse, and office. As a revolutionary who had fervently subscribed to the ideal of civic equality, Bosch now bitterly observed that the 'titles of burger and burgeres were again replaced by those of Madame and My Lord'. 'Everything', he lamented repeatedly in his journal, 'slowly and gently turns back to the way it was.. ${ }^{104}$ Bosch was among the first to notice that the well-todo class gradually resumed their old administrative offices and positions as in the old days. "The old traits of being distinguished, respectable, rich, moral, and capable, has nowadays again become a requirement.'105 A fictive letter from Paris in De heer Janus Janus-zoon reported a comparable change of climate in France: 'No-one speaks any longer of the factions of Jacobins, Royalists, Moderates, etc..' The 'word patriot is seldom heard - nor is the word Citoyen'.106 In another fictitious dialogue between a regent and a farmer, which did not necessarily reflect Bosch's views but should be read as his impression of the temperature of public opinion, he portrayed the farmer as totally disillusioned after years of revolution; the regent judged that the people were not yet enlightened, not ripe, not virtuous enough for revolution. The principles of the revolutionary era were appealing in theory, the regent said, but inapplicable in practice. ${ }^{107}$

The waning influence of radical republicans and their removal from the centre of power encouraged Orangist publicists to let their voices be heard again in public writing. Generally their tone was one of unity behind the fatherland, but theirs was a unity from which revolutionary republicans were explicitly excluded - revolutionaries, according to one venomous Orangist publication of the time, who had been educated in the 'School of Robespierre'.108 One such Orangist voice was Johannes le Franq van Berkhey,

104 Burger Politieke Blixem 1, No. 2, pp. 9-16, at p. 13. He repeated this lamentation in issue 49 of 16 February 1801, pp. 397-404, at p. 403. Burger Politieke Blixem 1, No. 5, pp. 33-40, at p. 34.

105 Burger Politieke Blixem 1, No. 5, pp. 33-40, at p. 36.

106 De Heer Janus Janus-zoon, no. 14, 30 July 1801, pp. 105-112, at p. 106.

107 Burger Politieke Blixem 1, No. 6, pp. 41-48.

108 [Anonymous], Bedenkingen over den tegenswoordigen staat van Nederland (Amsterdam: M. de Bruin, 1802), p. 132. 
an ardent Orangist physicist, poet, painter, and author of a multi-volume natural history of The Netherlands, who in 1801 published a lengthy poem entitled De Bataafsche menschlijkheid of de gevolgen der tweedracht: betoogt uit de rampen van het vaderland in vijfhonderd twee-en-zestig scherpdichterlijke sluitvaerzen en rondborstige vraegen naer de rechten van den mensch voor de tribune der eendracht (Batavian Humaneness or the Results of Discord: Based on the Disasters of the Fatherland in two hundred sixty-two Sharp Poetical Verses and Plain Questions about the Rights of Man before the Tribunal of Concord). ${ }^{109}$ Van Berkhey fulminated against Bosch's two journals, the relatively moderate tone of which had not made a huge impression on him. Former revolutionaries could do no good anymore. According to Van Berkhey's poem, the blame for civic discord and faction could only be put on one group: the revolutionary republicans. Verse after verse, he related them to the French 'acerbic Jacobins' who had committed 'thousands evil deeds' and 'barbarous inhumaneness', making use of the guillotine, the 'instrument of murder'. The poem mocked the revolutionaries' principles, their 'political science, their professed 'indomitable humaneness', their inciting of 'rage' and 'faction', and their spurring of 'the rabble to mutiny'. At the same time, the poem revealed what a renewed depoliticized and patriotic citizenship from an Orangist perspective would amount to. As verses 165 and 202 read:

If a tranquil citizen seeks to remain Outside of people and government If he longs for peace and quietness And does not wish to encourage discord Then he will never lose his right On nature and humaneness

And on the Batavian revolutionaries:

Thus People and City are abandoned, Was it Honest, Dignified, Dutifully The citizenship of the Batavian? Are they subjects of welfare?

109 Le Francq van Berkhey's De Bataafsche menschlijkheid of de gevolgen der tweedracht: betoogt uit de rampen van het vaderland in vijfhonderd twee-en-zestig scherpdichterlijke sluitvaerzen en rondborstige vraegen naer de rechten van den mensch voor de tribune der eendracht (Leiden: J. van Thoir, 1801) appeared under the pseudonym Janius Laconicus Franco Batavus. 
Or is it disloyalty

To the duties of humaneness?110

The disparagement and condemnation of Orangist publicists of Batavian revolutionaries, and their somewhat easy rhetoric of identifying them with Jacobin terrorists, is not surprising given that the political tide had turned. They had regained self-confidence and hated the Batavian Revolution and its antiOrangist agenda.

In this light the extent to which former revolutionaries distanced themselves from their former commitment to what they considered to be principles of an Atlantic age of revolutions is all the more remarkable. One of the principle ideologues and revolutionary leaders of January 22, Willem Anthonie Ockerse, represents this moment of disillusionment more than anyone else. After the coup d'état of June 12, 1798, Ockerse had ended up in prison. He was soon released, but his role as politician was played out. In a lecture in March 1803 to the society Doctrina et amicitia where he regularly gathered with some of his old partners in revolution Wiselius and Gogel, Ockerse reflected:

We have lived through the age of revolution, seen the world republicanize; but did we not at the same time see so much horrors, and was this republicanizing not too dear a price to pay, soured our hearts to such an extent, that we, together with our brothers of the entire globe, are fed up with it for a century or so? 111

Ockerse's evaluation was that 'fraternity' had incited 'terror' and brought Europe 'death'. It had proved impossible and too early to reap the political benefits of enlightened sociability.

In a follow-up lecture the next year, Ockerse came to see the political translation of high-minded citizenship ideals as an utter failure. It is worthwhile to quote Ockerse at length here. He did not deny that '[e]very member of society has a fixed inclination [...] to fully reclaim his natural right'. But

110 Le Francq van Berkhey, De Bataafsche menschlijkheid of de gevolgen der tweedracht, pp. 43, 53 .

111 W.A. Ockerse, 'Verhandeling over der menschen neiging tot gezelligheid; en over de beste middelen, om die neiging aan het algemeen geluk dienstbaar te maken. Eerste gedeelte. Voorgelezen in genootschap Doctrina et amicitia den 14den Maart 1803', in: idem, Redevoeringen, nagelaten door W.A. Ockerse (Amsterdam: Johannes van der Hey en zoon, 1826), pp. 171-194, at pp. 188-189. 
[i]f this natural instinct is aroused by misrule and oppression, it deteriorates into rebelliousness, and ends in national revolt. This was the true source of France's, of Europe's latest revolutionary impulse. For many years, dissatisfaction was brewing. Great philosophers, a Montesquieu, Rousseau, Voltaire, Barbeirac, Raynal, and others, fuelled it by recommending a philosophical design to improve the organization of society. The sweet poison was gulped down; the spastic convulsion broke out in raging anger. - A general enthusiasm of popular rule spread like the bubonic plague from one people to another. - The chosen cruelties became child's play to a gentle people, to a most civilized continent; and like all excesses of enthusiasmus, the revolutions destroyed themselves; like Saturn they devoured their own children; peoples, on their Icarus-wings too close to the sun of imaginary perfection, plump into a cesspool of superstition and misery deeper than ever before; in a word, the idea of a philosophical restoration of societies has failed completely.12

A general disillusionment, then, took hold of a generation of Batavian revolutionaries of which Ockerse was its most eloquent spokesman. The depoliticized citizenship ideals that came to dominate the period 1798-1801, and after, diverged strikingly from - and were often defined in opposition to - the revolutionary fervour of the early 1790s. The transatlantic mind set, the sense of sharing in a common project of citizen emancipation, was substituted for a depoliticized and nationalized citizenship discourse that would shape Dutch political culture for decades to come.

112 W.A. Ockerse, 'Verhandeling over den menschen neiging tot gezelligheid; en over de beste middelen, om die neiging aan het algemeen geluk dienstbaar te maken', in: Redevoeringen, nagelaten door W.A. Ockerse (Amsterdam: Johannes van der Hey, 1826), pp. 195-216, at pp. 202-204. 


\section{Epilogue: The Age of Revolutions as a Turning Point in the History of Citizenship}

In 1826, Samuel Wiselius, the former Batavian ideologue, revolutionary of the first hour in Amsterdam and Holland, and an influential voice on colonial affairs in the national political arena, recalled the revolutionary zeal which had so absorbed him in the 1790s: 'Who would deny the soundness of the principles of the de Lafayettes, the Condorcets [...] aimed at establishing the happiness of the French people?', he asked. But 'did these men, after having preached them, especially after immediately putting them into operation, also see their as such noble efforts be awarded with the desired result? - Alas! - Horrors of which humanity shivers, have followed from it'. Wiselius, who in 1797 had advocated a republican Batavian empire in which non-western natives and black slaves might gradually become citizens, admitted that the 'liberation of the Negroes' too, 'as such deserved the acclaim of Heaven and Earth', for 'slavery is contrary to human nature'. But 'which sensitive heart', he wondered, 'has not bled over the cries of anguish caused by the very same liberation?' The cause of all this, Wiselius held, is 'that by far the majority of the French, and the Negroes in general, were not sufficiently enlightened.' ${ }^{1}$ The republican experiment of the 1790 s had not yielded the results Wiselius had hoped for.

As this book has shown, the Haitian Revolution incited the invocation of a discourse of civilizational progress and backwardness to circumvent and counter the invoked logic of the rights of man and citizen. Many of these civilizational arguments for exclusion crystallized in the 1790s, precisely because it was in this decade that citizenship was redefined in a universalistic and egalitarian key. The exclusion of certain groups from citizenship required justifications responsive to the revolutionary principle of the equal rights of man. Saint-Domingue became, and would long remain, a key reference point in such schemes of argumentation. It was widely invoked as the ultimate proof that citizenship should not be attributed to those who are not (yet) civilized or enlightened. This discourse of the inequality between civilizations, which were considered to be in different stages of progress, was a product of a central strand of Enlightenment historical thinking and historiography. If the

1 S. Wiselius, 'Voorbereidend betoog', in: idem, De tooneelspeelkunst: inzonderheid met betrekking tot het treurspel, alsmede het nut en de zedelijke strekking des regelmatigen en beschaafden schouwtooneels, voorgesteld in twee voorlezingen bij het Genootschap voor uiterlijke welsprekendheid, in de jaren 1821 en 1822 (Amsterdam: P. Meijer Warnars, 1826), xxv-xxvii. 
Enlightenment contributed to the new conceptions of citizenship that were formulated in the age of revolutions, it also laid the groundwork for the exclusion of those who were not deemed capable to live up to the standards of 'enlightened' citizenship. ${ }^{2}$

From the perspective of the nineteenth and twentieth centuries, a crucial implication of this concept of citizenship was that it has been both potentially expansive and that it simultaneously could legitimize temporary regimes of exclusion. Gradually, the unenlightened, uneducated or uncivilized, could become enlightened and, thus, eligible for citizenship. In the 1820 and 1830 , for instance, the French abolitionist society Société de la moral chrétienne opposed immediate emancipation, as they wanted to prevent 'another Saint-Domingue'. Instead, the society proposed freedom by degrees and accordingly organized an essay on the questions of how slaves could gradually be made salaried workers' and 'how, by moral and religious education [...] they could be brought gradually, but promptly, without danger to themselves and their present owners, to enjoy fully political and civil liberties.' ${ }^{3}$ Gradualism, however, did not remain uncontested over the course of the nineteenth century. Virulent scientific racists such as Arthur, comte de Gobineau, in his Essai sur l'inégalité des races humaines (1853) declared in a deterministic vogue that 'in conformity with the highest natural law, the black variety belongs to the kind of branch of humanity that is not able to civilize itself'. The 'history of Haiti, of democratic Haiti', proved his point Gobineau thought, as it was 'nothing but a long account of massacres. ${ }^{4}$

In the southern United States, the reigning climate of opinion regarding the Saint-Domingue insurrection also hardened after 1800 . As has been extensively documented, the greatest anxiety for Americans in the southern states who

2 In his discussion of French republican universalism, Gary Wilder makes a similar point, but is less concerned with the discourse of civilizational inequality as such: ' $[\mathrm{P}]$ olitical exclusion was henceforth only legitimate for those groups whose members did not meet the new criteria of individuality, rationality, and autonomy [...] The point is that new forms of inequality were enabled by and entwined with republican principles; they expressed rather than violated the new political universalism'. Wilder, The French Imperial Nation-State, p. 16. Certain strands of Enlightenment thought, as intellectual historians have demonstrated, did criticize imperial domination and exploitation of slave-labour. But one is hard pressed to find entirely egalitarian conceptions of imperial citizenship. See S. Muthu, Enlightenment Against Empire (Princeton, N.J.: Princeton University Press, 2003).

3 Journal de la Société de la morale chrétienne 7 (1826), pp. 267-271. On the society, see L.C. Jennings, 'French anti-slavery under the Restoration: the Société de la morale chrétienne', Revue française d'histoire d'outre-mer 81 (1993), pp. 321-331.

4 A. de Gobineau, Essai sur l'inégalité des races humaines, 4 vols. (Paris: Librairie de Firmin Didot, 1853-1855), vol. 1, p. 81 . 
observed and reflected on Saint-Domingue was the 'contagion of rebellion'. The slave rebellion led by the blacksmith Gabriel in Richmond, Virginia, in 1800, as well as later slave rebellions in Barbados (1816), Demerara (1823), Jamaica (1831), and in Virginia (Nat Turner rebellion, 1831) only confirmed the conviction of many southern slaveholders that they should tighten, not loosen, their regime of human bondage. Of these rebellions, the Haitian Revolution was by far the most frightening example of a mass-scale slave insurrection in the antebellum American republic. ${ }^{5}$

The French 'experiment' remained a point of reference well into the nineteenth century, as did the argumentation based on civilizational exclusion of black slaves from citizenship. The Jeffersonian democrat John Taylor, a senator and member of the Virginia House of Delegates, generally deemed one of the most influential southern political theorists of the early nineteenth century, expressed an important strand of proslavery thought in his Arator: Being a Series of Agricultural Essays, Practical and Political, in sixty-one Numbers, of which five editions appeared between 1813 and 1818. In these essays he combined an initial appreciation of the French Revolution, a conception of the civilizational backwardness of black slaves, and the failure of a philosophical experiment:

The French revolution, bottomed upon as correct abstract principles and sounder practical hopes, turned out to be a foolish and mischievous speculation; what then can be expected from making republicans of negro slaves, and conquerors of ignorant infuriated barbarians? It attempted to make freemen of the people of France; the experiment pronounced that they were incapable of liberty. ${ }^{6}$

In addition, Bryan Edwards' History of the West Indies remained one of the prime texts southern pro-slavery advocates referred to. In the Virginia House of Delegates in February 1820, Alexander Smyth, a Republican politician who served in both the Virginia Senate and House of Delegates as well as the US House of Representatives, read entire passages from Edward's book, drawing parallels between the 'philosophers, the abolition societies, and societies of friends of the negroes, in Europe, who [...] produced the catastrophe of St. Domingo' and the 'philanthropists, societies, and popular meetings of the north' who are pursuing a 'similar course'. After having quoted the passage

5 Clavin, Toussaint Louverture and the American Civil War; Hunt, Haiti's Influence on Antebellum America; Rugemer, The Problem of Emancipation, esp. Ch. 2; White, Encountering Revolution, esp. Ch. 4.

6 J. Taylor, Arator: Being a Series of Agricultural Essays, Practical and Political, in sixty-one Numbers (Georgetown, D.C.: J.M. Carter, 1813), p. 128. 
where Edwards argues that the black insurrectionists were driven 'into those excesses - reluctantly driven - by the vile machinations of men calling themselves philosophers', Smyth concluded: 'Here we have a satisfactory proof of the ill effects of partial emancipation in a slave-holding country'. ${ }^{7}$ The same year extracts of Edward's History of the West Indies also appeared in the St. Louis Enquirer (Missouri). The publication appeared in the midst of nationwide debates about the admittance of Missouri as a slave state. ${ }^{8}$ It resounded the language and fears of the 179os. The editor's introduction mentioned that the extracts

are submitted in the hope that they will lead them to reflect upon the PRACTICAL CONSEQUENCES which must result from the present wide spread SYSTEM of inculcating the NATURAL EQUALITY of the BLACKS and the WHITES, and induce them to take MEASURES in time for the prevention of the CALAMITIES which were produced by the operation of a similar system in the Island of St. Domingo. ${ }^{9}$

Comparing the 'Robesperrian society of Amis des Noirs' with the antislavery societies 'in old England and New England', who 'are now labouring to produce the same result in the South and West', the author went on to single out the letter of the Abbé Grégoire. This 'celebrated letter was the text out of which all the restriction advocates took their arguments'. Relying on Edwards, the author pictured a future where liberated black ex-slaves, like the 'freed negroes of St. Domingo', would live as 'savages in the midst of society'. ${ }^{10}$ By implication, the message of such reflections on the French-Haitian Revolution was that the prospect of black slaves becoming citizens was out of the question.

From the 1830 onward, the discourse of gradualism and environmentalism was increasingly challenged by a more deterministic, quasi-scientific racism based on ethnological research and polygenetic theories of separate races. This body of beliefs, alongside other lines of argumentation, was increasingly employed by pro-slavery advocates in the southern United States to legitimize their slave-based society. ${ }^{11}$ References to Saint-Domingue and the theme of

$7 \quad$ St. Louis Enquirer (St. Louis, Missouri), April 19, 1820.

8 R.P. Forbes, The Missouri Compromise and its Aftermath: Slavery \& the Meaning of America (Chapel Hill, N.C.: University of North Carolina Press, 2007).

9 St. Louis Enquirer (St. Louis, Missouri), April 19, 1820.

10 St. Louis Enquirer (St. Louis, Missouri), August 26, 1820 (capitalization in original).

11 See G.M. Frederickson, The Black Image in the White Mind: The Debate on Afro-American Character and Destiny, 1817-1914 (New York: Harper \& Row, 1971), pp. 71-96; Dain, A Hideous Monster of the Mind, pp. 197-226. See also Jeffrey Young's introduction in J.R. Young 
civilizational inequality, however, persisted. Thomas Roderick Dew, the prominent southern proslavery writer and president of the College of William and Mary, the foremost college of Virginia and the American south at the time, in his widely distributed and influential review of the slavery debate in the Virginia General Assembly in 1831-32 held that the negro race was 'vastly inferior in the scale of civilization'. The theme of anarchy and exceptional savagery was central to Dew's invocation of Saint-Domingue. He recalled the 'bloodiest and most shocking insurrection ever recorded in the annals of history'. The whole island 'was involved in frightful carnage and anarchy'.12 After his discussion of the anarchy of Saint-Domingue, Dew concluded: 'The ground upon which we shall rest our argument on this subject is, that the slaves, in both an economical and moral point of view, are entirely unfit for a state of freedom among the whites' ${ }^{13}$ Dew explicitly based his reasoning on the views of 'Dr. Robertson' [the Scottish Enlightenment historian William Robertson, rk], who had explained that societies develop through different stages. 'Let us reflect on these things', Dew concluded, referring to the French experiment in Saint-Domingue, 'and learn wisdom from experience: the relations of society generated by the lapse of ages cannot be altered in a day'. ${ }^{14}$

The reasoning behind this exclusion which was based on the alleged lack of civilization and enlightenment was not only applied to black slaves or nonwestern peoples. Although one important argument of this book has been that the existing historiography has not sufficiently taken into the account the civilizational qualification of citizenship within the realm of empire, the significance of this discourse of enlightened citizenship was broader. It was also applied domestically. As we have seen, French Thermidorians felt no hesitation to describe Montagnard revolutionaries and the sans-culottes as 'savages'. Disillusioned Dutch revolutionaries such as Ockerse and Wiselius ascribed the failed experiment of the republican revolutions of the 179os to the lack of enlightenment of the majority of the population.

(ed.) Proslavery and Sectional Thought in the Early South, 1740-1829: An Anthology (Columbia, S.C.: University of South Carolina Press, 2006), pp. 1-67.

T.R. Dew, Review of the Debate in the Virginia Legislature of 1831 and 1832 (Richmond: T.W. White, 1832). Citations are taken from: 'Professor Dew on Slavery. Review of the Debate in the Virginia Legislature, 1831-32', in: The Pro-Slavery Argument as maintained by the most Distinguished Writers of the Southern States; containing the Several Essays, on the Subject, Chancellor Harper, Governor Hammond, Dr. Simms, and Professor Dew (Philadelphia, PA: LippinCott, Grambo, \& Co., 1853), pp. 287-49o, at pp. 288-289.

13 'Professor Dew on Slavery', pp. 421-422 (italic in original).

14 'Professor Dew on Slavery', pp. 297, 490 (italic in original). 
The view that large sections of the population, both domestically and within the realm of the empire, had to be educated and brought into the ambit of civilization - and until that point had been reached, should be excluded from politics - would become a mainstay in most varieties of nineteenth-century French and Dutch liberalism. The limitations placed on white manhood suffrage were justified by what has been termed a 'discourse of capacity' and premised on the 'immaturity' of the mass, as Pierre Rosanvallon and Alan Kahan have shown. Citizenship, in short, required education..$^{15}$ As Eugen Weber has noted, domestic programs in the second half of the nineteenth century aimed at turning 'peasants into Frenchmen' bore strong resemblances to colonial civilization missions, as contemporaries themselves also remarked. '[T] he famous hexagon can itself be seen as a colonial empire', peasants too were to be 'civilized'. 16

In The Netherlands, the spectre of Saint-Domingue also continued to be invoked in relation to the question of slavery. The writings of the progressive colonial reformer Dirk van Hogendorp, the one-year older brother of the future statesman Gijsbert Karel van Hogendorp, show that the 'lessons' of SaintDomingue echoed as far as the East Indies. Dirk, a declared admirer of Raynal and Rousseau, had resided in the Dutch Indies between 1785 and 1799 as admiralty officer and merchant of the Dutch East India Company, later as 'regent' (colonial administrator) of various regions, and eventually as governor of EastJava between 1794 and $1798 .{ }^{17}$ In a sequel to his Berigt van den tegenwoordigen toestand der Bataafsche nederzettingen (Report on the Present State of the Batavian Settlements, 1799) Van Hogendorp advocated the gradual extension of civic rights to the indigenous Indonesian population, but declared that he was 'aware of the danger and fatal consequences that would follow from the

15 P. Rosanvallon, Le sacre du citoyen. Histoire intellectuelle du suffrage universel en France (Paris: Gallimard, 1992), esp. pp. 209-249, 355-372; A. Kahan, Liberalism in NineteenthCentury Europe. The Political Culture of Limited Suffrage (Basingstoke: Palgrave Macmillan, 2003); A. Craiutu, Liberalism under Siege. The Political Thought of the French Doctrinaires (Lanham, MD: Lexington Books, 2003), p. 223; Furet, Revolutionary France, p. 333.

16 E. Weber, Peasants into Frenchmen. The Modernization of Rural France, 1870-1914 (Stanford, CA: Stanford University Press, 1976), pp. 5, 485.

17 He quoted Raynal on the frontispice of Berigt (n. 127). Quotes of Rousseau appeared on the title page of two of his other writings. Dirk also recommended Raynal to his brother in a letter. See E. du Perron-De Roos, 'Correspondentie van Dirk van Hogendorp met zijn broeder Gijsbert Karel', Bijdragen tot de Taal-, Land- en Volkenkunde van Nederlandsch-Indië 102 (1943), pp. 125-273, at p. 130. 
sudden liberation of slaves; and in the French colonies this has been proven by experience.'18

Others, such as the Dutch judge and future president at the Surinam Court of Civil Affairs A.F. Lammens in 1818 looked back at the revolutionary era and sighed that ' $[t]$ here were no limits anymore to the desire for equality and fraternity'. The 'careless and wrong' application of otherwise 'affectionate principles' had caused the destruction of Saint-Domingue, once 'the most beautiful colony in the world. ${ }^{19}$ That same year, Johannes van den Bosch, the future governor-general of the Dutch East Indies (1830-1833), Minister of the Colonies (1834-1840), and architect of the Cultivation System (Cultuurstelsel), argued that political and social institutions should always correspond with a people's stage of civilization and that colonial reform should always be gradual, otherwise the 'scenes of Saint-Domingue' would be repeated. ${ }^{20}$ In his Bezwaren tegen den geest der Eeuw (Objections against the Spirit of the Age, 1823), one of the more notorious Dutch counter-enlightenment critiques of the early nineteenth century, the Portuguese Jewish convert and leading figure in the Dutch Protestant Réveil Movement, Isaac da Costa, claimed:

Philosophy in this day and age endeavours everywhere to turn the course of nature, as well as of Providence: hence she demanded with loud cries the freedom of negroes, without consideration, without precaution, without examining whether these people were susceptible to, or at least ripe for, liberation. What has been the result? The destruction of the colonies, the murdering of planters, complete anarchy, bloody and lethal wars. $^{21}$

18 D. van Hogendorp, Berigt van den tegenwoordigen toestand der Bataafsche nederzettingen in Oost-Indien en den handel op dezelve; benevens eenige denkbeelden tot verandering en hervorming van het bestuur daarover (Delft: M. Roelofswaert, 1800) [Report on the Present State of the Batavian Settlements in East Indies and of its Trade; Together with some Views on the Change and Reform of its Governance]. The quote can be found in the sequel Stukken rakende den tegenwoordigen toestand der Bataafsche bezittingen in Oost-Indië en den handel op dezelve (The Hague: Leeuwestyn, 1801), pp. 377-378.

19 A.F. Lammens, Redevoering ten betooge: dat de sterfte of het afnemen van het getal der negerslaven, in de kolonie Suriname, niet zoo zeer aan mishandelingen, maar hoofdzakelijk aan andere oorzaken, moet toegeschreven worden, 2nd ed. (Amsterdam. G.S. Leeneman van der Kroe, 1823 [1819]).

$20 \mathrm{~J}$. van den Bosch, Nederlandsche bezittingen in Azia, Amerika en Afrika. In derzelver toestand en aangelegenheid voor dit Rijk, wijsgeerig, staatshuishoudkundig en geographisch beschouwd, 2 vols. (Amsterdam: Van Cleef, 1818) [(Dutch possessions in Asia, America, and Africa [...] in philosophical, political-economical, and geographical perspective)], I, xvi; II, p. 212.

21 I. da Costa, Bezwaren tegen den geest der eeuw, 3rd ed. (Leiden: L. Herdingh, 1823), p. 26. 
Whether conceptualized in terms of permanent racial inferiority or semipermanent civilizational backwardness, the essential point is that such considerations of the Haitian Revolution discredited the assumption of the inherent potential of black (and non-western) people to raise to the status of full-fledged citizens, an assumption that was foundational to earlier revolutionary pro-emancipatory visions. In the short run, then, across the Atlantic such invocations of the Haitian Revolution worked against, rather than contributed to, the extension of citizenship to black and coloured people. ${ }^{22}$ The revolutionary momentum that had spurred unprecedented visions of radically opening up the office of modern republican citizenship was over.

These observations, although far from exhaustive, point to a legacy of references and lines of reasoning that originated in the 1790 s and have not yet been made sufficiently explicit in the existing scholarship. Undoubtedly, the Haitian Revolution, which led to the first black independent state in the New World, inspired generations of black, as well as more generally antislavery and anticolonial activists around the world. However, as this book has shown, the 1790 s were also the breeding ground for exclusive visions of citizenship based on civilizational inequality, as well as an important moment in the disenchantment of many Americans and Dutchmen at the time, with French revolutionary experiments in racial equality.

While the slave revolt in Saint-Domingue raised questions about equality and the universal applicability of the rights of man, the Terror in Jacobin France led many to substantially reconsider the revolutionary, democraticrepublican ideal of participatory citizenship. American Federalists, French Thermidorians, as well as a considerable number of Batavian revolutionaries came to hold deep suspicions about politicized popular societies. They feared a faction-ridden citizenry, and sought to exclude certain social classes from participation in politics. In their view, popular societies were an infringement on the principle of the indivisible unity of the people. They breed faction, and to their minds faction was destructive to a republican polity. Citizens who were attached to popular societies and gathered in unruly masses, they thought, lose their independency of judgment and reasoning. Such platforms of citizen participation do not represent the 'will of the people'. They only represent particular interests. Federalists, Thermidorians, and certain currents within the

22 Cf. G.S. Wood, Empire of Liberty: A History of the Early Republic, 1789-1815 (Oxford: Oxford University Press, 2009), p. 533; P.S. Foner, History of Black Americans (Westport, CT: Greenwood Press, 1975), pp. 472-473; L.C. Jennings, French Anti-Slavery: The Movement for the Abolition of Slavery in France, 1802-1848 (Cambridge: Cambridge University Press, 2000), pp. 20-21. 
Batavian revolutionary movement, wanted to get rid of this kind of mediation and bind the citizen directly to the state.

Certainly, the overall revolutionary experience of the 179os created different political and intellectual legacies on both sides of the Atlantic. Under the constitutional monarchies of the French Bourbons (1814-1830), the July Monarchy of Louis-Philippe I of Orleans (1830-1848), and in The Netherlands under King William I (1815-1840) and King William II (1840-1849), the ideal of a broad, politically active citizenry laid deeply buried under the consensus between 'notables' and the constitutionally limited monarch. In the newly founded Dutch kingdom, the vast majority of the population was expected to behave as loyal subjects, not as active citizens, and certainly not in politicized clubs. The vibrant literary and reading societies kept well away from politics and the press hardly discussed political issues until the late $1820 s$. Domestic life was promoted under the figure of the king as a 'father amidst his family', where faction had been substituted for loyalty to a unified fatherland. The politicized, democraticrepublican citizenship of the Batavian Revolution was actively suppressed, only to be revived, if in a different and moderate form, in the $1840 .^{23}$

In France, the revolution bequeathed a more powerful as well as more contested revolutionary republican tradition. ${ }^{24}$ The democratic-republican ideal of participatory citizenship only resurfaced with force during the Second Republic (1848-1851). Prominent restoration or 'Doctrinaire' liberals such as François Guizot and Pierre Paul Royer-Collard, who had gained prominence and took on leading roles under the July Monarchy (1830-1848), relied on the 'sovereignty of reason', and denounced popular sovereignty, universal suffrage, and a politically active citizenry. ${ }^{25}$ Guizot explicitly referred to the Montagnard constitution of 1793 and the Terror to criticize 'the unrealistic conception of

23 R. Aerts, 'Het ingetogen vaderland: huiselijkheid, maatschappelijke orde en publieke ruimte', in: I. de Haan, P. den Houd, and H. te Velde (eds.) Een nieuwe staat. Het begin van het Koninkrijk der Nederlanden (Amsterdam: Prometheus, 2014), pp. 251-274; idem, 'Een staat in verbouwing. Van Republiek naar constitutioneel koninkrijk, 1780-1848', in: R. Aerts, H. de Liagre Böhl, P. de Rooy, and H. te Velde, Land van kleine gebaren. Een politieke geschiedenis van Nederland, 1780-199o (Nijmegen: Sun, 1999), esp. pp. 68-72; I. de Haan, Het beginsel van leven en wasdom. De constitutie van de Nederlandse politiek in de negentiende eeuw (Amsterdam: Wereldbibliotheek, 2003); J. van Zanten, Schielijk, Winzucht, Zwaarhoofd en Bedaard. Politieke discussie en oppositievorming 1813-1840 (Amsterdam: Wereldbibliotheek, 2004), pp. 39-58.

24 S. Hazareesingh, Political Traditions in Modern France (Oxford: Oxford University Press, 1994); Furet, Revolutionary France.

25 Rosanvallon, Le sacre du citoyen, pp. 232-237. 
civic virtue. ${ }^{26}$ The roots of this passive, depoliticized, and socio-politically narrowed down conception of citizenship stem from the 1790 .

In the long-term history of American democracy and citizenship, the decade of the 179os, however contentious, faction-ridden, and tumultuous, was in a way a test that was passed successfully. Violence was contained; no civil war broke out. The authoritarian Federalist measures of the late 179os and the infringements on the freedom of opinion and press were reversed. Jefferson's election in 1800 was, in the end, a bloodless affair, a peaceful democratic transition of power. The 'age of federalism' was over. Partisan democratic citizenship, although generally still considered undesirable and dangerous, had not led to the destruction of the republic. In that sense, the 179os rendered partisanship more acceptable. ${ }^{27}$ The decades following the 1790 s witnessed gradual democratization and the emergence of a democratic party culture that increasingly clashed with the 'deferential-republican' political culture of the eighteenth century. ${ }^{28}$ In the first quarter of the nineteenth century, many states expanded white adult male suffrage. ${ }^{29}$ The contrast with continental Europe could not be starker. It only enhanced the impression, rooted in the second half of the 179os, that the early American Republic was set on a different path when compared to France, and that white male American citizenship, as an idea and ideal, was a category sui generis. At any rate, American visions of democratic citizenship were no longer considered to be part of a larger Atlantic revolutionary movement. ${ }^{30}$

Indeed, in the United States as well as in the Batavian Republic, although emphases differed, the notion that there was a particular model of American or Dutch citizenship which was in any case not French - or British - was partly a result from the disenchantment with the idea of a transatlantic revolutionary movement. National citizenship was not only a product of the age of revolutions in the sense that the concept of nation was theorized as the sovereign power in society. National citizenship was also not only a product of nationalism conceived as a political program, even though this was eminently

26 Craiutu, Liberalism under Siege, pp. 137-138.

27 Cf. Koschnik, "The Democratic Societies of Philadelphia and the Limits of the American Public Sphere', p. 636.

28 For 'deferential-republican' as description of the early American Republican's political 'regime', see M. Keller, America's Three Regimes. A New Political History (New York: Oxford University Press, 2007).

29 Wilentz, The Rise of American Democracy, pp. 116-118, 177, 191.

3o Cf. Cotlar, Tom Paine's America. 
important. ${ }^{31}$ The experiences of, and reflections on, the age of revolution as such also contributed to the very nationalization of notions of citizenship. The Atlantic Thermidor, the disintegration of the vision of a transatlantic revolutionary movement underpinned by highly universalistic civic ideals, left a vacuum to be filled by more national interpretations of what it means to be a citizen.

The nationalization of citizenship during and after the tumultuous decade of the 1790s differed significantly in the three countries under discussion. In the early American Republic of the 1790s, those who endorsed the Federalist persuasion and whose enthusiasm about the French Revolution had waned early on, were repelled by the news from France about the violence and chaos and what they considered a hopeless universalist utopianism. Although many a Republican would endorse the revolutionary principles from the other side of the Atlantic until deep into the 179os, slaveholding Republicans from the South would be appalled by the ways in which successive French revolutionary governments dealt with the enslaved population of their crown colony. Taken together, the Haitian Revolution and the Terror estranged large groups of Americans from the notion of a shared Atlantic revolutionary program. The rise of Napoleon Bonaparte and his authoritarian regime essentially only confirmed what revolutionary France had already showed to them, namely that their own form of government and ideal of citizenship, even though Americans also differed amongst themselves, was certainly not French. After the purchase of Louisiana from Napoleon in 1803, and after the War of 1812 with Great Britain broke the 'emotional connection' with their former colonial sovereign, Americans turned West, away from the Old World. ${ }^{32}$ The American Revolution, and the gradual democratization of the American polity was no longer associated with a wider Atlantic movement, but set apart from it.

In The Netherlands, the Batavian Revolution could never attain the status in national historiography and collective memory as the American or French revolutions did in the United States and France, respectively. Although the Batavian revolutionaries founded the centralized Dutch nation-state and introduced a representative democracy as well as the first modern constitution, the revolutionary experience would forever be tainted by the gradual French takeover, the occupation, and ultimately the assimilation into Napoleon's

31 D.A. Bell, The Cult of the Nation in France. Inventing Nationalism, 1680-1800 (Cambridge, MA: Harvard University Press, 2003); W.H. Sewell, 'The French Revolution and the Emergence of the Nation Form', in: M.A. Morrison and M.S. Zook (eds.) Revolutionary Currents: Nation Building in the Transatlantic World (Lanham, MD: Rowman \& Littlefield, 2004), pp. 91-125.

32 Wood, Empire of Liberty, p. 701. 
empire in 1810 . The founding of the constitutional monarchy headed by the House of Orange in 1813-1815 was a moment of liberation, stabilization, and nationalization. The Batavian Republic, a 'boulevard of broken dreams', as one historian aptly put it, was actively erased from memory. ${ }^{33}$ The disassociation from the age of Atlantic revolutions, and the rejection of its model of democratic-republican citizenship in the nineteenth century, was by implication a way to stow the memories of their own revolutionary experiment.

Finally, we have seen that in France the early nationalization efforts of centrist Thermidorians by invoking a discourse of the 'good citizen' failed miserably. Unlike Dutchmen and Americans, Frenchmen could not externalize the 1790 - the defining decade in the history of modern France. Under Napoleon, the republican experiment could be partly incorporated and reshaped, and partly effectively suppressed. Under the constitutional monarchies (18151848), 'national' citizenship was problematic. In the hands of the republican camp, 'nationalism' was divisive rather than unitary, since it was hardly possible for French monarchists and Catholics to identify with it. ${ }^{34}$ During most of the nineteenth century, the legacy of the republic was simply too contested to become nationalized.

Recognizing these divergent paths of the nationalization of citizenship, however domestically contested, as products of the very interaction between national political conflicts and a wider, transnational horizon, might gain insights into mechanisms that still seem to operate in many parts of the world today. The limits of citizenship, and the question who is entitled to what citizenship rights, are on top of the political agenda and not likely to be settled, as many countries in the world are struggling with large-scale movements of migrants and refugees. A consensus about the appropriate platform for, and extent of citizen participation in politics is also not likely to be reached soon. Many observe an objectionable and everwidening distance between citizens and political decision-making processes, while at the same time there seems to be a broad skepticism in democracies worldwide about the involvement of citizens in policy making in too direct ways. The perspective on the age of Atlantic revolutions as a turning point in the history of citizenship offered in this

33 The phrase 'A boulevard of broken dreams' is Van Sas's. See his 'De Republiek voorbij'. On the erasure of the Batavian Revolution from Dutch collective memory, see M. Lok, "Un oubli total du passé"?: The Political and Social Construction of Silence in Restoration Europe (1813-1830)', History and Memory 26 (2014), pp. 40-75.

34 S. Hazareesingh, 'The Two Faces of French Nationalism', in: idem, Political Traditions in Modern France, pp. 124-150; C. Nicolet, L'idée républicaine en France (1789-1924). Essai d'histoire critique (Paris: Gallimard, 1982); P.M. Pilbeam, Republicanism in Nineteenth-Century France, 1814-1870 (Basingstoke: Palgrave Macmillan, 1995). 
book reminds us that public debates about the limits of inclusion and participation are often bound up with, and shaped by concrete historical experiences that transcend national boundaries. Revolutions, revolutionary 'experiments' in democratic participation and civic equality, and the universalistic logics invoked to legitimize them, tend to generate their own counterarguments, as well as create their own regimes of exclusion. 


\section{Bibliography}

\section{Primary Sources}

[Anonymous], Bedenkingen over den tegenswoordigen staat van Nederland (Amsterdam: M. d. Bruin, 1802).

Adams, J., Antwoord op het werk van den heer Thomas Paine, getiteld Rechten van den mensch (Haarlem: Walgré, 1793).

Adams, J.Q., An Oration, Pronounced July 4th, 1793, at the Request of the Inhabitants of the Town of Boston (Boston, MA: B. Edes \& Son, 1793).

Albany Centinel (Albany, New York).

Albany Gazette (Albany, New York).

Albany Register (Albany, New York).

American Mercury (Hartford, Connecticut).

American Museum (Philadelphia, Pennsylvania).

Amic, A., and Mouttet, E., (eds.) La tribune française: choix des discours et des rapports les plus remarquables prononcés dans nos assemblées parlementaires depuis 1789 jusqu'à 1840, 2 vols. (Paris: Bureaux de la tribune française, 1840).

Andrews's Western Star (Stockbridge, Massachusetts).

Apollo; or, Chestertown Spy (Chestertown, Maryland).

Argus (Boston, Massachusetts).

Aurora General Advertiser (Philadelphia, Pennsylvania).

Barruel, A., Memoirs Illustrating the History of Jacobinism (Hartford, CO: Hudson \& Goodwin, 1799).

Baudry Deslozières, L.N., Les égarements du nigrophilisme (Paris: Migneret, 1802).

Béraud, P.E., The Siege of Lyons (During the Dictatorship of Robespierre), trans. from the French (Stockbridge, MA: Loring Andrews, 1795).

Bijdragen tot het menschelijk geluk (Amsterdam).

Boissy d'Anglas, F.A., Projet de constitution pour la République français, et discours préliminaire prononcé par Boissy d'Anglas au nom de la Commission des onze (Paris: Imprimerie de la république, 1795).

Boissy d'Anglas, F.A., Vertoog bij de aanbieding van het ontwerp van constitutie, voor de Fransche Republiek (Haarlem: F. Bohn, 1796).

[Bosch, B.], Vrijhart aan het volk van Nederland over de waare constitutie (n.p., 1793).

Bonnemain, A.-J.-T., Régénération des colonies, ou moyens de restituer graduellement aux hommes leur état politique et d'assurer la prospérité des nations (Paris: Imprimerie du Cercle Social, 1792).

Brissot, J.-P., Discours sur la nécessité d'établir à Paris une société pour concourir, avec celles d'Amérique \& de Londres, à l'abolition de la traite \& de l'esclavage des nègres (Paris: n.p., 1788). 
Brissot, J.-P., 'Discours sur la question de savoir si le roi peut être jugé prononcé à l'assemblée des amis de la constitution dans la séance du 10 juillet 1791', in: Aulard, F.V.A., La Société des Jacobins; recueil de documents, 6 vols. (Paris: Jouaust, 18871897), vol. 2. Burger Politieke Blixem (Leiden).

Cabanis, P.J.G., Rapports du physique et du moral de l'homme, 2 vols. (Paris: Caille et Ravier, 1815 [1802]).

Cabanis, P.J.G., Opinion de Cabanis, sur les réunions s'occupant d'objets politiques (Paris: Baudouin, Imprimeur du Corps Législatif, n.d.).

Carlisle Gazette (Carlisle, Pennsylvania).

The Centinel of Freedom (Newark, New Jersey).

Chateaubriand, M., CEuvres Complètes, 5 vols. (Paris: Didot, 1842).

Clarkson, T., An Inquiry into the Causes of the Insurrection of the Negroes in the Island of St. Domingo. To which are added, Observations of M. Garran-Coulon on the same Subject, read in his Absence by M. Guadet, before the National Assembly, 29th Feb. 1792 (London: Johnson, 1792).

The City Gazette, Or The Daily Advertiser (Charleston, South Carolina).

Claypoole's Daily Advertiser (Philadelphia, Pennsylvania).

Colenbrander, H.T. (ed.) Gedenkstukken der algemeene geschiedenis van Nederland van 1795 tot 1840, 10 vols. (Den Haag: Martinus Nijhoff, 1905-1922).

Columbian Herald or the Southern Star (Charleston, South Carolina).

Columbian Centinel (Boston, Massachusetts).

Connecticut Courant (Hartford, Connecticut).

Connecticut Journal (New Haven, Connecticut).

Constitutions des Treize États-Unis de l'Amérique, trans. La Rochefoucauld (Paris: Pierre, 1783).

Condorcet, Lettres d'un citoyen des États-Unis à un Français sur les affaires présentes (Philadelphia, PA, n.p., 1788).

Condorcet, CEuvres de Condorcet, ed. Condorcet O'Connor, A., and Arago, F., 12 vols. (Paris: Firmin Didot Frères, 1847).

Condorcet, Writings on the United States, ed. and trans. G. Ansart (Philadelphia, PA: Pennsylvania State University Press. 2012).

Condorcet, Political Writings, ed. Lukes S., and Urbinati, N. (Cambridge: Cambridge University Press, 2012).

Costa, I. da, Bezwaren tegen den geest der eeuw, 3rd ed. (Leiden: L. Herdingh, 1823).

Cras, H.C., Verhandeling over de gelykheid der menschen, en de regten en pligten, welken uit die gelykheid voortvloeijen (Haarlem: Enschedé \& van Walré, 1793).

[Cras, H.C.], Gewigtig advys over de vraag: moet eene constitutie de Nationale conventie; of een Nationale conventie, de constitutie voorafgaan? (n.p., n.p. [1795]).

Crèvecœur, J. Hector St. John de, Letters from an American Farmer: Describing certain Provincial Situations, Manners, and Customs, not generally known; and conveying 
some Idea of the Late and Present Interior Circumstances of the British Colonies of North America (London: T. Davies, 1782).

Crèvecœur, J. Hector St. John de, Brieven van eenen Amerikaenschen landman van Carlisle in Pennsijlvanien; geschreven aen eenen zijner vrienden in Engeland; behelzende den toestand, zeden, landbouw, en gewoonten der inwoonders van eenige der nu Vereenigde dertien gewesten van Noord Amerika, voor en in den nu geëindigden oorlog (Leiden: L. Herdingh, 1784).

Crèvecœur, J. Hector St. John de, Lettres d'un cultivateur américain (Maastricht: J.E. Dufour \& P. Roux, 1785).

Cumberland Gazette (Falmouth, Massachusetts).

Dagverhaal der handelingen van de Nationaale Vergadering representeerende het Volk van Nederland; van de tweede Nationale Vergadering; van de Nationaale en Constitueerende Vergadering representeerende het Bataafsche volk, 9 vols. (The Hague: Van Schelle, 1796-1798).

The Daily Advertiser (New York, New York).

Damas-Hinard, J.J. (ed.) Napoleon, ses opinions et jugemens sur les hommes et sur les choses, 2 vols. (Paris: Duféy, 1838).

De democraten (Utrecht).

De gruwel der verwoestingen, of Vrankryks moord- en treur-tooneel: Ter eeuwiger gedachtenis vertoond in een aantal fraaije afbeeldingen en naauwkeurige verhaalen an de voornaamste gebeurtenissen, geduurende de jongste revolutie in het ongelukkig Vrankryk voorgevallen. Ten leer-en schrikbeeld voor alle volken van Europa, en inzonderheid voor Neêrlands ingezeetenen (Amsterdam: J. Peppelenbos, 1794).

De Heer Janus Janus-zoon (The Hague).

Dew, T.R. 'Review of the Debate in the Virginia Legislature, 1831-32', in: The Pro-Slavery Argument as maintained by the most Distinguished Writers of the Southern States; containing the Several Essays, on the Subject, Chancellor Harper, Governor Hammond, Dr. Simms, and Professor Dew (Philadelphia, PA: LippinCott, Grambo, \& Co., 1853), pp. 287-490.

The Diary or Loudon's Register (New York, New York).

Dunlap's American Daily Advertiser (Philadelphia, Pennsylvania).

Dunlap and Claypoole's American Daily Advertiser (Philadelphia, Pennsylvania).

Dupont de Nemours, P.S., Observations sur la constitution proposée par la commission des onze et sur la position actuelle de la France (Paris: Du Pont Imprimeur, 1795).

Dwight, T., An Oration, spoken before the Connecticut Society, for the Promotion of Freedom and the Relief of Persons unlawfully holden in Bondage (Hartford, CT: Hudson and Goodwin, 1794).

Dwight, T., The Duty of Americans, at the Present Crisis, illustrated in a Discourse preached on the Fourth of July, 1798 (New Haven, CO: Gree, 1798).

Eagle (Hanover, New Hampshire). 
Edwards, B., An Historical Survey of the French Colony in the Island of St. Domingo comprehending a Short Account of its Ancient Government, Political State, Population, Productions, and Exports; A Narrative of the Calamities which have desolated the Country ever since the Year 1789, with some Reflections on their Causes and Probable Consequences, and a Detail of the Military Transactions of the British Army in that Island to the End of 1794 (London: J. Stockdale, 1797).

Edwards, B., The History, Civil and Commercial, of the British Colonies in the West Indies, 4 vols. (London: Crosby, 1798).

Federal Intelligencer (Baltimore, Maryland).

Federal Gazette \& Baltimore Daily Advertiser (Baltimore, Maryland).

The Federal Gazette and Philadelphia Daily Advertiser (Philadelphia, Pennsylvania).

Federal Orrery (Boston, Massachusetts).

Garran-Coulon, J.P., Rapport sur le troubles de Saint-Domingue, fait au nom de la Commission des Colonies, des Comités de Salut Public, de Législation, et de Marine, réunis, 4 vols. (Paris: Imprimerie nationale, An V [1797-1798]).

The Gazette of the United States (Philadelphia, Pennsylvania).

Gedenkwaardige brieventas almanach voor het jaar MDCCXCIII (n.p., 1793).

Greenfield Gazette (Greenfield, Massachusetts).

Greenleaf's New YorkJournal and Patriotic Register (New York, New York).

Grégoire, H., Essai sur la régénération physique, morale et politique des Juifs (Paris: Éditions du Boucher, 2002 [1789]).

Grégoire, H., Lettre aux citoyens de couleur et nègres libres de Saint-Domingue et des autres isles françoises de l'Amérique (Paris: Imprimerie du Patriote Français, 1791).

Grégoire, H., De la traite et de l'esclavage des noirs et des blancs (Paris: A. Égron, 1815).

Grégoire, H., Mémoires de Grégoire, ancien évêque de Blois (Paris: A. du Pont, 1837).

Gobineau, A. de, Essai sur l'inégalité des races humaines, 4 vols. (Paris: Librairie de Firmin Didot, 1853-1855).

Godwin, W., Enquiry Concerning Political Justice (Philadelphia, PA: Bioren and Madan, 1796).

Gouges, O. de, L'esclavage des noirs, ou l'heureux naufrage (Paris: Duchesse, 1792).

Herald (New York, New York).

Herald or, the New Daily Advertiser (Charleston, South Carolina).

Historiesch schouwtooneel van 'swaerelds lotgevallen; in het jaar 1792 (Haarlem: Loosjes, 1792).

Hamelsveld, Y. van, Vertoog over de middelen, tot voltooijing en handhaaving van de de goede zaak dervryheid; voorgedragen aan de burgerij van Leyden (Leiden: C. de Pecker, 1795).

Hamilton, A., The Papers of Alexander Hamilton, H.C. Syrett (ed.), 27 vols. (New York, N.Y.: Columbia University Press, 1961-1987). 
Hogendorp, D. van, Berigt van den tegenwoordigen toestand der Bataafsche nederzettingen in Oost-Indien en den handel op dezelve; benevens eenige denkbeelden tot verandering en hervorming van het bestuur daarover (Delft: M. Roelofswaert, 1800).

Hogendorp, D. van, Stukken rakende den tegenwoordigen toestand der Bataafsche bezittingen in Oost-Indië en den handel op dezelve (The Hague: Leeuwestyn, 1801).

Hogendorp, G.K. van, Verhandelingen over den Oost-Indischen handel (Amsterdam: J. Doll, 1801).

Holbach, P. von, Christianity Unveiled; being, an Examination of the Principles and Effects of the Christian Religion (New York: Columbian Press, 1795).

The Independent Chronicle (Boston, Massachusetts).

Independent Gazetteer (Philadelphia, Pennsylvania).

Janius Laconicus Franco Batavus [Franq van Berkhey, J. le], De Bataafsche menschlijkheid of de gevolgen der tweedracht: betoogt uit de rampen van het vaderland in vijfhonderd twee-en-zestig scherpdichterlijke sluitvaerzen en rondborstige vraegen naer de rechten van den mensch voor de tribune der eendracht (Leiden: J. van Thoir, 1801).

Jefferson, T., The Papers of Thomas Jefferson DigitalEdition, ed. Oberg, B.B., and Looney, J.J. (Charlottesville, VA: University of Virginia Press, Rotunda, 2008), http://rotunda .upress.virginia.edu/founders/TSJN-01-17-02-0002 [abbr. PTJ].

Journal de la Société de la morale chrétienne (Paris).

Kemp, F.A. van der, Verzameling van stukken tot de dertien vereenigde Staeten van Noord-America (Leiden: L. Herdingh, 1781).

Konijnenburg, J., and Stuart, M., Tafereelen van de staatsomwenteling in Frankrijk, 25 vols. (Amsterdam: J. Allart, 1794-1809).

[Kluit, A.], De rechten van den mensch in Vrankrijk, geen gewaande rechten in Nederland. Of Betoog, dat die rechten bij het volk van Nederland in volle kracht genoten worden en iets over onze vrijheid en patriotismus. Door een patriot (Amsterdam: W. Brave, 1793).

Lammens, A.F., Redevoering ten betooge: dat de sterfte of het afnemen van het getal der negerslaven, in de kolonie Suriname, niet zoo zeer aan mishandelingen, maar hoofdzakelijk aan andere oorzaken, moet toegeschreven worden, 2nd ed. (Amsterdam. G.S. Leeneman van der Kroe, 1823 [1819]).

Lathrop, J., The Happiness of a Free Government, and the Means of Preserving It: Illustrated in a Sermon, Delivered in West-Springfield, on July 4th, 1794, in Commemoration of American Independence (Springfield, MA: Hutchins, 1794).

De leerzame praat-al (Amsterdam).

Lezay, A., Les ruines ou voyage en France pour servir de suite à celui de la Grèce (Paris : Migneret, 1796).

Lindet, R., Rapport fait à la Convention nationale dans la séance du 4ème des SansCulottides de l'an 2ème, au nom des Comités de salut public, de sûreté générale et de 
législation, réunis, sur la situation intérieure de la république, par Robert Lindet, Représentant du peuple, et membre du comité de salut public (Montauban: Chez Fontanel, imprimeur de la société populaire, an III [1795]).

Loosjes, A., Gedenkzuil: ter gelegenheid der vry-verklaaring van Noord-America (Amsterdam: Holtrop, 1782).

Mably, G.B. de, Observations sur le gouvernement et les loix des États-Unis (Amsterdam: Rosart, 1784).

Madival, J., et al. (eds.) Archives parlementaires de 1787 à 1860, 127 vols. (Paris: Librairie administrative de P. Dupont, 1862-) [abbr. AP].

The Mail; or, Claypoole's Daily Advertiser (Philadelphia, Pennsylvania).

[Mandrillon, J.], Spectateur américain ou remarques générales sur l'Amérique septentrionale et sur la République des Treize-Etats-Unis (Amsterdam: E. van Harrevelt, 1784).

Marck, F.A. van der, Schets over de rechten van den mensch, het algemeen kerken-staatsen volkerenrecht, ten dienste der burgery ontworpen (Groningen: J. Bolt, 1798).

Mazzei, P., Recherches historiques et politiques sur les États-Unis de L'Amérique Septentrionale (Paris: Froullé, 1788).

Meerman, J., De burgerlyke vryheid in haare heilzaame, de volks-vryheid in haare schadelyke gevolgen voorgesteld, inzonderheid met betrekking tot dit gemeenebest (Leiden: Luchtmans, 1793).

Mémoires de l'institut national des sciences et arts pour l'an IV de la république (Paris: Baudouin, 1797).

Middlesex Gazette (Middletown, Connecticut).

Miller, S., A Sermon, preached in New-York, July 4th, 1793: Being the Anniversary of the Independence of America, at the Request of the Tammany Society, or Columbian Order (New York, N.Y.: T. Greenleaf, 1793).

The Minerva (New York, New York).

Mirabeau, Aux Bataves, sur le stadhouderat (Amsterdam: n.p., 1788).

Mirabeau, Batavieren, over het stadhouderschap (Antwerpen: P. Rymers, 1788).

Morse, J., A Sermon, Delivered at the New North Church in Boston..., May 9th, 1798 (Boston, MA: S. Hall, 1798).

National Gazette (Philadelphia, Pennsylvania).

New-Hampshire Gazette (Portsmouth, New Hampshire).

The New Hampshire and Vermont Journal: Or, The Farmer's Weekly Museum (Walpole, New Hampshire).

New-Jersey Journal (Elizabethtown, New Jersey).

New-York Daily Gazette (New York, New York).

The New-York Journal, \& Patriotic Register (New York, New York).

Nieuwe bijdragen tot het menschelijk geluk (Utrecht).

Nieuwe Post van den Neder-Rhijn (Utrecht). 
The North-Carolina Journal (Halifax, North Carolina).

Ockerse, W.A., Ontwerp tot eene algemeene characterkunde, 3 vols. (Utrecht: G.T Paddenburg, 1788-1797).

[Ockerse, W.A.], De Constitutie der Franschen verdedigd tegen de lasterlijke grondbeginsels van de leden der Sociëteit In de Kroon en het Anker te Londen vergaderende (n.p., 1793).

[Ockerse, W.A.], Bataven! Eischt eene Nationale Conventie! of beroep aan het Bataafsche Volk (n.p., 1795).

[Ockerse, W.A.], Redevoeringen, nagelaten door W.A. Ockerse, ed. Clarisse, J., (Amsterdam: J. van der Hey, 1826).

Paape, G., De onverbloemde geschiedenis van het Bataafsch Patriottismus van deszelfs begin (1782) tot op den 12 Junij 1798 toe (Delft: M. Roelofswaart, 1798).

Paine, T., [Treat Paine Jr., R.,], An Oration, written at the Request of the Young Men of Boston, and delivered, July 17th, 1799: In Commemoration of the Dissolution of the Treaties, and Consular Convention, between France and the United States of America (Boston, MA: J. Russell, 1799).

Paine, T., [Treat Paine Jr., R.,], Adams and liberty. A New Patriotic Song (Baltimore, MD: Hanna and Greene, Thomas, Andrews \& Butler, and Solomon Cotton \& Co, 1798).

Paine, T., [Treat Paine Jr., R.,], The Works in Verse and Prose of the late Robert Treat Paine, Jun. Esq. with notes. To which are prefixed Sketches of his Life, Character and Writings (Boston, MA: J. Belcher, 1812).

Paine, T., Rechten van den mensch, of De aanval van den heer Burke op de Fransche omwenteling / beantwoord door Thomas Paine (Amsterdam and Rotterdam: Meyer and Brongers, 1791).

Paine, T., Brief aan 't Fransche volk (Amsterdam: Brongers, 1792).

Paine, T., Het gezond verstand (Dordrecht, n.p., 1794).

Paine, T., Burgerpligt-leerende redevoering aan het volk / door Thomas Payne, en deszelfs gevoelen ... betreffende de gerechtelyke beoordeeling van Lodewyk den zestienden: met eene voorrede van den uitgever over de vryheid en gelykheid, en het recht van vry spreken en schryven, byzonder der Nederlanderen (Amsterdam: Brongers, 1794).

Paine, T., Dissertation on the First Principles of Government (London: Eaton, 1795).

Paine, T., Verhandeling over de eerste beginsels der regeering (Leiden: Murray and Loosjes, 1795).

Paine, T., De eeuw der rede. Zijnde eene nasporing van ware en fabelachtige godgeleerdheid (The Hague: Leeuwestyn, 1798).

Paine, T., The Political Writings of Thomas Paine, 2 vols. (Charleston, S.C.: Davidson, 1824).

Paine, T., Collected Writings, ed. Foner, E., (New York: Classic House, 2009).

Palm, J.H. van der, Redevoeringen, verhandelingen en losse geschriften, 5 vols. (Leeuwarden: G.T.N. Suringar, 1854-1855). 
Paulus, P., Verhandeling over de vrage: in welken zin kunnen de menschen gezegd worden gelyk te zyn? En welke zyn de regten en pligten die daaruit voordvloeien? (Haarlem: C. Plaat, 1793).

Philadelphia Gazette (Philadelphia, Pennsylvania).

Phoenix (Dover, New Hampshire).

Playfair, W., The History of Jacobinism: Its Crimes, Cruelties and Perfidies: Comprising an Inquiry into the Manner of Disseminating, under the Appearance of Philosophy and Virtue, Principles which are Equally Subversive of Order, Virtue, Religion, Liberty and Happiness; with an Appendix by Peter Porcupine, Containing a History of the American Jacobins, commonly denominated Democrats (Philadelphia, PA: W. Cobbett, 1796).

Price, R., Aanmerkingen over den aart der burgerlyke vrijheid, over de gronden der regeering, en over de rechtveerdigheid en staatkunde van den oorlog met Amerika, trans. Capellen tot den Pol, J.D. van der, (Leiden: Herding, 1776).

The Providence Gazette and Country Journal (Providence, Rhode Island).

Raimond, J., Observations adressées à l'Assemblée Nationale par un député des colons américains (n.p., 1789).

Raimond, J., Observations sur l'origine et les progrès du préjugé des colons blancs contre les hommes de couleur (Paris: Belin, 1791).

Raimond, J., Réflexions sur les véritables causes des troubles et des désastres de nos colonies (Paris, n.p., 1793).

Ramsay, D., The History of the Revolution in South-Carolina, From a British Province to an Independent State, 2 vols. (Trenton, N.J.: Collins, 1785).

Ramsay, D., The History of the American Revolution, 2 vols. (Philadelphia, PA: Aitken, $1789)$.

Ramsay, D., A Dissertation on the Manners of Acquiring the Character and Privileges of a Citizen (n.p., 1789).

Ramsay, D., 'David Ramsay, 1749-1815: Selections from His Writings', Brunhouse, R.L. (ed.), Transactions of the American Philosophical Society 55 (1965).

Rapport van de burgers Goldberg, Verbeek en Scheffer, uitgebragt in eene vergadering van de Societeit voor eenheid en orde in Den Haag, over het ontwerp van constitutie, zo als het zelve door de Nationaale Vergadering, representeerende het volk van Nederland, aan het Bataaffsche volk ter goed of afkeuring is voorgedragen (The Hague: I. van Cleef, 1797).

Règlement de la société des amis des noirs et des colonies, adopté dans sa Séance tenue à Paris le 3 o Frimaire an VII (Paris: l'Imprimerie des sciences et arts, 1798).

Réimpression de l'ancien Moniteur, seule histoire authentique et inaltérée de la révolution française depuis la réunion des Etats-généraux jusqu'au consulat, 32 vols. (Paris: Plon, 1858-1863). 
Republican Gazette (Concord, New Hampshire).

Le républicain (Paris).

De republikein (Amsterdam).

Révolutions de Paris (Paris).

Riouff, H., Revolutionary Justice Displayed; or an Inside View of the Various Prisons of Paris, under the Government of Robespierre and the Jacobins. Taken Principally from the Journals of the Prisoners Themselves, trans. from the French (Philadelphia, PA: 1796).

Robertson, W., History of America, 2 vols. (Dublin: Whitestone, 1777).

Robison, J., Proofs of a Conspiracy against all the Religions and Governments of Europe (Philadelphia, PA: Dobson and Cobbet, 1798).

Roederer, P.L., CEuvres du comte P.L. Roederer, ed. Roederer, A.M., 8 vols. (Paris: FirminDidot frères, 1853-1859).

Rogge, C., Geschiedenis der Staatsregeling, voor het Bataafsche volk (Amsterdam: J. Allart, 1799).

Rural Repository (Leominster, Massachusetts).

Russell's Gazette. Commercial and Political (Boston, Massachusetts).

Salem Gazette (Salem, Massachusetts).

Say, J.-B., Olbie (Paris: Deterville, 180o).

Schimmelpenninck, R.J., Verhandeling over eene wel ingerigte volksregeering (Leiden: F. de Does, 1785).

Schutte, G., 'Verhandeling over den tegenwoordigen volks-geest, in zoo verr' dezelve door de wijsbegeerte gewijzigd is', Nieuwe bijdragen tot het menschelijkgeluk 1 (1797), pp. 127-151.

Sieyès, Political Writings, including the Debate between Sieyès and Paine in 1791, trans. Sonenscher, M., (Indianapolis, IN: Hackett, 2003).

The South-Carolina State-Gazette (Charleston, South Carolina).

Soulès, F., Histoire des troubles de l'Amérique anglaise (Paris: Buisson, 1787).

Stanhope Smith, S., An Essay on the Causes of the Variety of Complexion and Figure in the Human Species: To which are added Strictures on Lord Kaims's Discourse, on the Original Diversity of Mankind (Philadelphia, PA: R. Aitken, 1787).

Staël, Madame de, CEuvres Complètes, série I, 1, ed. F. Lotterie (Paris: Honoré Champion Éditeur, 2008).

Stevens, J., Examen du gouvernement d'Angleterre comparé aux constitutions des EtatsUnis de l'Amérique, par un cultivateur de New-Jersey (Paris: Froullé, 1789).

St. Louis Enquirer (St. Louis, Missouri).

[Swildens, J.H.], Politiek belang-boek voor dit provisioneel tydperk (Amsterdam:J.R. Poster, 1795).

Sun (Dover, New Hampshire). 
The Sun (Pittsfield, Massachusetts).

Taylor, J., Arator: Being a Series of Agricultural Essays, Practical and Political, in sixty-one Numbers (Georgetown, D.C.: J.M. Carter, 1813).

Timoleon [Wortman, T.], A Solemn Address to Christians and Patriots (New York: D. Denniston, 180o), in: Sandoz, E., (ed.) Political Sermons of the American Founding Era: 1730-1805, 2 vols. (Indianapolis, IN: Liberty Fund, 1998), vol. 2, pp. 1477-1528.

Tucker, G., A Dissertation on Slavery: With a Proposal for the Gradual Abolition of It in the State of Virginia (Philadelphia, PA: M. Carey, 1796).

Vitringa, H.H., Gedenkschrift van Herman Hendrik Vitringa, 4 vols. (Arnhem: Nijhoff, 1857-1864).

Vaderlandsche Bibliotheek van Wetenschap, Kunst, en Smaak (Amsterdam).

Vaderlandsche Letteroefeningen (Amsterdam).

Vermont Gazette (Bennington, Vermont).

Verzameling van instructiën, ordonnanciën en reglementen voor de regering van Nederlandsch Indië, vastgesteld in de jaren 1609, 1617, 1632, 1650, 1807, 1815, 1818, 1827, 1830 en 1836, met de ontwerpen der Staats-commissie van 1803 en historische aanteekeningen (Batavia: Lands-drukkerij, 1848).

Verzameling van de constitutiën der vereenigde onafhanglijke staaten van Amerika, 2 vols. (Dordrecht: F. Wanner, 1781).

Volney, C.F. de Chassebœuf, comte de, Common sense; or Natural Ideas Opposed to Supernatural (New York, n.p., 1795).

Volney, C.F. de Chassebœuf, comte de, The Law of Nature, or Principles of Morality, deduced from the Physical Constitution of Mankind and the Universe (Philadelphia, PA: Stephens and Baily, 1796).

Voltaire, Philosophical Dictionary (New York: J. Fellows \& E. Duyckinsk, 1796).

Wadström, C.B., Précis sur les établissements des colonies de Sierra Leona et de Boulama à la côte occidentale d'Afrique (Paris: Pouyens, 1798).

Wadström, C.B., Adresse au Corps législatif et au Directoire exécutif de la République française (Paris, Imprimerie des sciences et arts, 1795).

Washington, G., The George Washington Papers at the Library of Congress 1741-1799, ed. Fitzpatrick, J.C., available at: http://lcweb2.loc.gov/ammem/gwhtml/gwhome.html.

Webster, N., Effects of Slavery, on Morals and Industry (Hartford, CO: Hudson and Goodwin, 1793).

Webster, N., The Revolution in France, considered in Respect to its Progress and Effects. By an American (New York, N.Y.: G. Bunce, 1794).

Western Star (Stockbridge, Massachusetts).

Wiselius, S., De tooneelspeelkunst: inzonderheid met betrekking tot het treurspel, alsmede het nut en de zedelijke strekking des regelmatigen en beschaafden schouwtooneels, voorgesteld in twee voorlezingen bij het Genootschap voor uiterlijke welsprekendheid, in de jaren 1821 en 1822 (Amsterdam: P. Meijer Warnars, 1826). 
Wiselius, S., Proeve over de verschillende regeringsvormen in derzelver betrekking tot het maatschappelijk geluk (Leiden: Luchtmans, 1831).

\section{Secondary Literature}

Adams, W.H., The Paris Years of Thomas Jefferson (New Haven, CT: Yale University Press, 1997).

Adams, W.P., The First American Constitutions. Republican Ideology and the Making of the State Constitutions in the Revolutionary Era, trans. Kimber, R., (Chapel Hill, N.C.: The University of North Carolina Press, 1980).

Adelman, J., Sovereignty and Revolution in the Iberian Atlantic (Princeton, N.J.: Princeton University Press, 2006).

Adelman, J., 'An Age of Imperial Revolutions', American Historical Review 113 (2008), pp. 319-40.

Aerts, R., 'Het ingetogen vaderland: huiselijkheid, maatschappelijke orde en publieke ruimte', in: De Haan, Den Houd, and Te Velde (eds.) Een nieuwe staat. Het begin van het Koninkrijk der Nederlanden, pp. 251-274.

Aerts, R., et al., Land van kleine gebaren. Een politieke geschiedenis van Nederland, $1780-$ 1990 (Nijmegen: Sun, 1999).

Ageron, C.R., France coloniale ou parti colonial? (Paris: Presses universitaires de France, 1978).

Ahlskog, J., 'The Political Economy of Colonisation: Carl Bernhard Wadström's Case for Abolition and Civilisation', Sjuttonhundratal: Nordic Yearbook of Eighteenth Century Studies (2010), pp. 146-68.

Albertone, M., and Francesco, A. de, (eds.), Rethinking the Atlantic World: Europe and America in the Age of Democratic Revolutions (Basingstoke: Palgrave Macmillan, 2009).

Andress, D., 'The Course of the Terror, 1793-1794', in: McPhee (ed.) A Companion to the French Revolution, pp. 293-310.

Appleby, J., 'The Jefferson-Adams Rupture and the First French Translation of John Adams' "Defence”, American Historical Review 73 (1968), pp. 1084-1091.

Appleby, J., 'The Radicalism of the American Republic', 'How Revolutionary was the Revolution? A Discussion of Gordon S. Wood's The Radicalism of the American Revolution', in: The William and Mary Quarterly 51 (1994), pp. 679-684.

Appleby, J., Capitalism and a New Social Order: The Republican Vision of the 179os (New York: New York University Press, 1984).

Arendt, A., On Revolution (New York: Viking, 1963).

Armitage, D., The Declaration of Independence: A Global History (Cambridge, MA: Harvard University Press, 2007). 
Armitage, D., and Subrahmanyam, S., (eds.), The Age of Revolutions in Global Context, c. 1760-1840 (Basingstoke: Palgrave Macmillan, 2010).

Baczko, B., Ending the Terror: The French Revolution after Robespierre, trans. Petheram, M., (Cambridge: Cambridge University Press, 1994).

Baczko, B., 'Ici on s'honore du titre du citoyen', in: Monnier (ed.), Citoyen et citoyenneté sous la Révolution française, pp. 9-21.

Baecque, A. de, Le corps de l'histoire. Métaphores et politique (1770-180o) (Paris: Calmann-Lévy, 1993).

Baggerman, A., and Dekker, R., Kind van de toekomst. De wondere wereld van Otto van Eck (1780-1798) (Amsterdam: Wereldbibliotheek, 2005).

Bailyn, B., Atlantic History: Concept and Contours (Cambridge, MA: Harvard University Press, 2005).

Baker, K.M., 'Politics and Social Science in eighteenth-century France: The Société de 1789', in: Bosher, J.F. (ed.) French Government and Society 1500-1850 (London: Athlone Press, 1973), pp. 208-230.

Baker, K.M., Inventing the French Revolution. Essays on French Political Culture in the Eighteenth Century (Cambridge: Cambridge University Press, 1990).

Baker, K.M., 'The Idea of a Declaration of Rights', in: Van Kley (ed.) The French Idea of Freedom, pp. 154-196.

Baker, K.M., 'Transformations of Classical Republicanism in Eighteenth-Century France', Journal of Modern History 73 (2001), pp. 32-53.

Baker, K.M., 'Political Languages of the French Revolution', in: Goldie and Wokler (eds.) The Cambridge History of Eighteenth-Century Political Thought, pp. 626-659.

Baker, K.M., 'Idioms, Discourses, and Improvisation', in: Kaiser and Van Kley (eds.) From Deficit to Deluge. The Origins of the French Revolution, pp. 165-197.

Baker, K.M., (ed.), The French Revolution and the Creation of Modern Political Culture, 4 vols. (Oxford: Pergamon, 1987-1994).

Baker, K.M., and Edelstein, D., (eds.) Scripting Revolution. A Historical Approach to the Comparative Study of Revolutions (Stanford, CA: Stanford University Press, 2015).

Balibar, E., 'Citizen Subject', in: Cadava, E., Connor, P., and Nancy, J., (eds.) Who Comes After the Subject? (London: Routledge, 1991), pp. 33-57.

Banning, L., The Jeffersonian Persuasion: Evolution of a Party Ideology (Ithaca, N.Y.: Cornell University Press, 1978).

Barker, H., and Burrows, S., (eds.) Press, Politics and the Public Sphere in Europe and North America, 1760-1820 (Cambridge: Cambridge University Press, 2002).

Bayley, C.A. The Birth of the Modern World, 1780-1914: Global Connections and Comparisons (Oxford: Wiley Blackwell, 2003).

Beeman, R.R., The Varieties of Political Experience in Eighteenth-Century America (Philadelphia, PA: University of Pennsylvania Press, 2004). 
Bell, D.A. Lawyers and Citizens. The Making of a Political Elite in Old Regime France (Oxford: Oxford University Press, 1994).

Bell, D.A. The Cult of the Nation in France. Inventing Nationalism, 1680-180o (Cambridge, MA: Harvard University Press, 2003).

Bell, D.A. 'Questioning the Global Turn: The Case of the French Revolution', French Historical Studies 37 (2014), pp. 1-24.

Bellamy, R., Citizenship. A Very Short Introduction (Oxford: Oxford University Press, 2008).

Bénot, Y., La Révolution française et la fin des colonies 1789-1794 (Paris: La Découverte, 1988).

Bénot, Y., La démence coloniale sous Napoléon (Paris: La Découverte, 1992).

Bénot, Y., 'Comment la Convention a-t-elle voté l'abolition de l'esclavage en l'an II ?', Annales historiques de la Révolution française 293-294 (1993), pp. 349-361.

Bénot, Y., Lumières, l'esclavage, la colonisation (Paris: La Découverte, 2005).

Bénot, Y., and Dorigny, M., (eds.), Rétablissement de l'esclavage dans les colonies françaises. Aux origines de Haïti (Paris: Maisonneuve et Larose, 2003).

Berkelbach van der Sprenkel, J.W., 'De Franse Revolutie in de contemporaine Hollandsche Couranten', De Gids 103 (1939), pp. 323-357.

Berlin, I., and Hoffman, R., (eds.), Slavery and Freedom in the Age of the American Revolution (Charlottesville, VA: University of Virginia Press, 1983).

Bernstein S., and Rudelle, O., (eds.) Le modèle républicain (Paris: Presses universitaires de France, 1992).

Berry, C.J., The Idea of Commercial Society in the Scottish Enlightenment (Edinburgh: Edinburgh University Press, 2013).

Bessel, R., Guyatt, N., Rendall, J., (eds.) War, Empire and Slavery, 1770-1830 (Basingstoke: Palgrave Macmillan, 2010).

Betts, R.F., Assimilation and Association in French Colonial Theory, 1890-1914, new ed. (Lincoln, NE: University of Nebraska Press, 2005, [1961]).

Bethencourt, F., Racisms. From the Crusades to the Twentieth Century (Princeton, N.J.: Princeton University Press, 2013).

Blackburn, R., The Overthrow of Colonial Slavery: 1776-1848 (London: Verso, 1988).

Blackburn, R., The American Crucible: Slavery, Emancipation and Human Rights (London: Verso, 2011).

Bloch, R.H., Visionary Republic: Millennial Themes in American Thought 1756-180o (Cambridge: Cambridge University Press, 1985).

Blom, J.C.H., (ed.) Geschiedenis van de Joden in Nederland (Amsterdam: Olympus, 1995).

Blouet, O.M., 'Bryan Edwards and the Haitian Revolution', in: Geggus (ed.) The Impact of the Haitian Revolution in the Atlantic World, pp. 44-57. 
Bossenga, G., The Politics of Privilege: Old Regime and Revolution in Lille (Cambridge: Cambridge University Press, 2002).

Bourke, R., Empire and Revolution. The Political Life of Edmund Burke (Princeton, N.J.: Princeton University Press, 2015).

Bouton, T., Taming Democracy: “The People”, the Founders, and the Troubled Ending of the American Revolution (Oxford: Oxford University Press, 2007).

Bradburn, D., The Citizenship Revolution: Politics and the Creation of the American Union 1774-1804 (Charlottesville, VA: University of Virginia Press, 2009).

Branda, P., and Lentz, T., Napoléon, l'esclavage et les colonies (Paris: Fayard, 2006).

Brandon, P., and Fatah-Black, K., 'For the Reputation and Respectability of the State': Trade, the Imperial State, Unfree Labor, and Empire in the Dutch Atlantic', in: Donoghue, J., and Jennings, E.P., (eds.) Building the Atlantic Empires: Unfree Labor and Imperial States in the Political Economy of Capitalism, ca. 1500-1914 (Leiden: Brill, 2015), pp. 84-108.

Branson, S., These Fiery Frenchified Dames: Women and Political Culture in early national Philadelphia (Philadelphia, PA: University of Pennsylvania Press, 2001).

Breen, T.H., The Marketplace of Revolution: How Consumer Politics shaped American Independence (Oxford: Oxford University Press, 2004).

Breman, J., Koloniaal profijt van onvrije arbeid: Het Preanger stelsel van gedwongen koffeteelt op Java, 1720-1870 (Amsterdam: Amsterdam University Press, 2010).

Brooke, J.L., 'Consent, Civil Society, and the Public Sphere in the Age of Revolution and the Early American Republic', in: Pasley, Robertson, and Waldstreicher (eds.), Beyond the Founders: New Approaches to the Political History of the Early American Republic, pp. 207-250.

Brown, H.G., Ending the Revolution: Violence, Justice, and Repression from the Terror to Napoleon (Charlottesville, VA: University of Virginia Press, 2006).

Brown, H.G., 'Robespierre's Tail: The Possibilities of Justice after the Terror', Canadian Journal of History 45 (2010), pp. 1758-94.

Brown, S.J. (ed.) William Robertson and the Expansion of Empire (Cambridge: Cambridge University Press, 2008).

Brubaker, R., 'The French Revolution and the Invention of Citizenship', French Politics and Society 7 (1989), pp 30-49.

Bruin, R.E. de, Burgers op het kussen: volkssoevereiniteit en bestuurssamenstelling in de stad Utrecht, 1795-1813 (Zutphen: Walburg Pers, 1986).

Buel, R., Securing the Revolution. Ideology in American Politics, 1789-1815 (Ithaca N.Y.: Cornell University Press, 1972).

Buijnsters, P.J., 'Lesegesellschaften in den Niederlanden', in: Dann (ed.) Lesegesellschaften und Bürgerliche Emanzipation, pp. 143-158.

Burbank, J., and Cooper, F., Empires in World History: Power and the Politics of Difference (Princeton, N.J.: Princeton University Press, 2010). 
Calloway, C.G., White People, Indians, and Highlanders. Tribal Peoples and Colonial Encounters in Scotland and America (Oxford: Oxford University Press, 2008).

Caron, P., Les massacres de Septembre (Paris: La maison du livre français, 1935).

Censer, J., Prelude to Power. The Parisian Radical Press, 1789-1791 (Baltimore, MD: Johns Hopkins University Press, 1976).

Césaire, A., Toussaint Louverture, La Révolution française et le problème colonial (Paris: Club français du livre, 1960).

Chartier, R., The Cultural Origins of the French Revolution, trans. Cochrane, L.G. (Durham, N.C.: Duke University Press, 1991).

Cheney, P., Revolutionary Commerce: Globalization and the French Monarchy (Cambridge, MA: Harvard University Press, 2010).

Clavin, M.J., 'Race, Revolution, and the Sublime: The Gothicization of the Haitian Revolution in the New Republic and Atlantic World', Early American Studies: An Interdisciplinary Journal 5 (2007), pp. 1-29.

Clavin, M.J., Toussaint Louverture and the American Civil War: The Promise and Peril of a Second Haitian Revolution (Philadelphia, PA: University of Pennsylvania Press, 2010).

Clément, J.-P., Aux sources du libéralisme français: Boissy d'Anglas, Daunou, Lanjuinais (Paris: L.G.D.J., 2000).

Cleves, R.H., The Reign of Terror in America: Visions of Violence from Anti-Jacobinism to Antislavery (New York: Cambridge University Press, 2009).

Conac, G., and Machelon, J.-P., (eds.), La Constitution de l'an III: Boissy d'Anglas et la naissance du libéralisme constitutionnel (Paris: Presses universitaires de France, 1999).

Cohen, W.B., The French Encounter with Africans: White Response to Blacks, 1530-1880 (Bloomington, IN: Indiana University Press, 1980).

Conklin, A.L., A Mission to Civilize: The Republican Idea of Empire in France and West Africa, 1895-1930 (Stanford, CA: Stanford University Press, 1997).

Colenbrander, H.T., De Bataafsche Republiek (Amsterdam: Meulenhoff, 1908).

Cooper, F., Citizenship between Empire and Nation. Remaking France and French Africa, 1945-196o (Princeton, N.J.: Princeton University Press, 2014).

Cooper, F., Citizenship, Inequality, and Difference (Princeton, N.J.: Princeton University Press, 2018).

Cooper, F., Holt, T.C., and Scott, R.J. (eds.), Beyond Slavery: Explorations of Race, Labor, and Citizenship in Postemancipation Societies (Chapel Hill, N.C.: University of North Carolina Press, 2000).

Cotlar, S., Tom Paine's America: The Rise and Fall of Transatlantic Radicalism in the Early Republic (Charlottesville, VA: University of Virginia Press, 2011).

Cour Grandmaison, O. Le, Les citoyennetés en Révolution: 1789-1794 (Paris: Presses Universitaires de France, 1992). 
Craiutu, A., Liberalism under Siege. The Political Thought of the French Doctrinaires (Lanham, MD: Lexington Books, 2003).

Craiutu, A., A Virtue for Courageous Minds: Moderation in French Political Thought, 1748-1830 (Princeton, N.J.: Princeton University Press, 2012).

Curran, A.S., The Anatomy of Blackness: Science \& Slavery in an Age of Enlightenment (Baltimore, MD: Johns Hopkins University Press, 2011).

Dain, B.R., Hideous Monster of the Mind: American Race Theory in the Early Republic (Cambridge, MA: Harvard University Press, 2002).

Daniel, M., Scandal \& Civility.Journalism and the Birth of American Democracy (Oxford: Oxford University Press, 2009).

Dann, O., (ed.) Lesegesellschaften und Bürgerliche Emanzipation. Ein europäeischer Vergleich (Munich: C.H. Beck, 1981).

Davis, D.B., The Problem of Slavery in the Age of Revolutions, 1770-1823 (Ithaca, N.Y.: Cornell University Press, 1975).

Desan, S., Hunt, L., Nelson, W.M. (eds.) The French Revolution in Global Perspective (Ithaca, N.Y.: Cornell University Press, 2013).

Dickinson, H.T., 'Popular Conservatism and Militant Loyalism, 1789-1815', in: Dickinson, (ed.) Britain and the French Revolution, 1789-1815, pp. 103-126.

Dickinson, H.T. (ed.) Britain and the French Revolution, 1789-1815 (Basingstoke: Macmillan, 1989).

Doel, H.W. van den, De Stille Macht: Het Europese binnenlands bestuur op Java en Madoera, 1808-1942 (Amsterdam: B. Bakker, 1994).

Dorigny, M., 'Grégoire et le combat contre l'esclavage pendant la Révolution', in: Dorigny and Bénot (eds.) Grégoire et la cause des noirs (1789-1831), pp. 51-68.

Dorigny, M., 'Intégration républicaine des colonies et projets de colonisation de l'Afrique: Civiliser pour émanciper?', in: Dorigny and Bénot (eds.) Grégoire et la cause des noirs (1789-1831), pp. 89-107.

Dorigny, M., 'La société des amis des noirs et les projets de colonisation en Afrique', Annales historiques de la Révolution française 293-294 (1993), pp. 421-429.

Dorigny, M., (ed.) The Abolitions of Slavery. from Léger Félicité Sonthonax to Victor Schoelcher (Oxford: Berghahn Books, 2003).

Dorigny, M., and Bénot, Y., (eds.) Grégoire et la cause des noirs (1789-1831). Combats et projets (Paris: Société française d'histoire d'Outre-mer, 2005).

Dorigny, M., and Gainot, B., La Société des amis des Noirs, 1788-1799: Contribution à l'histoire de l'abolition de l'esclavage (Paris: Editions UNESCO, 2006).

Dubois, L., 'Republican Antiracism and Racism: A Caribbean Genealogy', French Politics, Culture \& Society 18 (2000), pp. 5-17.

Dubois, L., A Colony of Citizens: Revolution and Slave Emancipation in the French Caribbean, 1787-1804 (Chapel Hill, N.C.: University of North Carolina Press, 2004). 
Dubois, L., Avengers of the New World: The Story of the Haitian Revolution (Cambridge, MA: Belknap Press of Harvard University Press, 2004).

Dubois, L., and Garrigus, J.D., Slave Revolution in the Caribbean, 1789-1804: A Brief History with Documents (Basingstoke: Palgrave Macmillan, 2006).

Dun, J.A., "What Avenues of Commerce, Will You, Americans, Not Explore!": Commercial Philadelphia's Vantage onto the Early Haitian Revolution', The William and Mary Quarterly 62 (2005), pp. 473-504.

Dun, J.A., Dangerous Neighbors. Making the Haitian Revolution in Early America (Philadelphia, PA: University of Pennsylvania Press, 2016).

Dunn, S., Sister Revolutions. French Lightning, American Light (New York: Faber and Faber, 1999).

Dupuy, R., and Morabito, M., (eds.) Pour une République sans Révolution (Rennes: Presses Universitaires de Rennes, 1996).

Durey, M., Transatlantic Radicals and the Early American Republic (Lawrence, KS: University Press of Kansas, 1997).

Echeverria, E., Mirage in the West. A History of the French Image of American Society to 1815 (New York: Octagon Books, 1966).

Edel, C.N., Nation Builder. John Quincy Adams and the Grand Strategy of the Republic (Cambridge, MA: Harvard University Press, 2014).

Edelstein, D., The Enlightenment: A Genealogy (Chicago, IL: University of Chicago Press, 2010).

Edelstein, D., 'Enlightenment Rights Talk', The Journal of Modern History 86 (2014), pp. 530-565.

Effenterre, H. van, 'La cité grecque, modèle de République des Républicains', in: Bernstein and Rudelle (eds.) Le modèle républicain, pp. 13-18.

Elkins, S.M., and McKitrick, E.L., The Age of Federalism (New York, N.Y.: Oxford University Press, 1993).

Fahrmeir, A., Citizenship. The Rise and Fall of a Modern Concept (New Haven, CT: Yale University Press, 2007).

Faÿ, B., L'Esprit révolutionnaire en France et aux États-Unis à la fin du XVIII e siècle (Paris: Edouard Champion, 1925).

Ferrer, A., Freedom's Mirror: Cuba and Haiti in the Age of Revolution (Cambridge: Cambridge University Press, 2014).

Fick, C., 'The Haitian Revolution and the Limits of Freedom: Defining Citizenship in the Revolutionary Era', Social History 32 (2007), pp. 394-414.

Foner, P.S., History of Black Americans (Westport, CT: Greenwood Press, 1975).

Foner, P.S., The Democratic-Republican Societies, 1790-180o: A Documentary Sourcebook of Constitutions, Declarations, Addresses, Resolutions, and Toasts (Westport, CT: Greenwood Press, 1976). 
Foner, P.S., (ed.), The Life and Major Writings of Thomas Paine (New York, N.Y.: Citadel Press, 1993 [1948]).

Fontana, N. (ed.), The Invention of the Modern Republic (Cambridge: Cambridge University Press, 1994).

Forbes, R.P., The Missouri Compromise and its Aftermath: Slavery \& the Meaning of America (Chapel Hill, N.C.: University of North Carolina Press, 2007).

Frederickson, G.M., The Black Image in the White Mind: The Debate on Afro-American Character and Destiny, 1817-1914 (New York: Harper \& Row, 1971).

Frijhoff, W., Jongedijk, M., and Rottier, R., 'Vryheid of de Dood'. La Révolution française vue des Pays-Bas, 1789-1798 (Amsterdam: Maison Descartes, 1789).

Fritzsche, P., Stranded in the Present. Modern Time and the Melancholy of History (Cambridge, MA: Harvard University Press, 2010).

Frothingham and Ellis, 'Extracts from Diary of Nathaniel Cutting', Proceedings of the Massachusetts Historical Society 12 (1871-1873), pp. 57-67.

Fuks-Mansveld, R.G., 'Verlichting en emancipatie omstreeks 1750-1813', in: Blom (ed.) Geschiedenis van de Joden in Nederland, pp. 177-203.

Furet, F., Interpreting the French Revolution, trans. Elborg, F., (Cambridge: Cambridge University Press, 1981).

Furet, F., Revolutionary France, 1770-1880 (Oxford: Blackwell, 1992).

Furet, F., and Richet, D., La Révolution française, 2 vols. (Paris: Hachette, 1965-66).

Furet, F., and Ozouf, M., (eds.) A Critical Dictionary of the French Revolution. Trans. Goldhammer, A., (Cambridge, MA: Belknap Press of Harvard University Press, 1989).

Gainot, B., 1799, un nouveau Jacobinisme? La démocratie représentative, une alternative à Brumaire (Paris: Éditions du CTHS, 2001).

Garrigus, D., Before Haiti: Race and Citizenship in French Saint-Domingue (Basingstoke: Palgrave Macmillan, 2006).

Garrigus, J.D., 'Opportunist or Patriot? Julien Raimond (1744-1801) and the Haitian Revolution', Slavery \& Abolition 28 (2007), pp. 1-21.

Gainot, B., 'La naissance des départements d'Outre-Mer. La loi du 1er janvier 1798', Revue d'histoire des Mascareignes et de l'Océan Indien 1 (1998), pp. 51-74.

Gainot, B., 'The Constitutionalization of General Freedom Under the Directory', in: Dorigny (ed.) The Abolitions of Slavery, pp. 180-196.

Gainot, B., 'La Décade et la "colonisation nouvelle"', Annales historiques de la Révolution française 339 (2005), pp. 99-116.

Gauchet, M., La révolution des droits de l'homme (Paris: Gallimard, 1989).

Gauchet, M., 'Rights of Man', in: Ozouf and Furet (eds.) A Critical Dictionary of the French Revolution, pp. 818-828.

Gauthier, F., '[review] Yves Bénot, 'La Révolution française et la fin des colonies', $A n$ nales historiques de la Révolution française 271 (1988), pp. 491-493. 
Gauthier, F., Triomphe et mort du droit naturel en Révolution. 1789-1795-1802 (Paris: Presses Universitaires de France, 1992).

Gauthier, F., L'aristocratie de l'épiderme: Le combat de la Société des Citoyens de Couleur, 1789-1791 (Paris: CNRS Éditions, 2007).

Geggus, D.P., 'Racial Equality, Slavery, and Colonial Secession during the Constituent Assembly', American Historical Review 94 (1989), pp. 1290-1308.

Geggus, D.P., [review] N. Nisbett, 'Universal Emancipation: The Haitian Revolution and the Radical Enlightenment', American Historical Review 114 (2009), pp. 1501-1502.

Geggus, D.P., The Haitian Revolution. A Documentary History (Indianapolis, IN: Hackett Publishing, 2014).

Geggus, D.P., 'Saint Domingue on the Eve of Revolution', in: Geggus and Fiering (eds.) The World of the Haitian Revolution, pp. 3-20.

Geggus, D.P., 'Rights, Resistance and Emancipation: A Response to Robin Blackburn', in: Tunstall (ed.) Self-Evident Truths?, pp. 157-167.

Geggus, D.P. (ed.) The Impact of the Haitian Revolution in the Atlantic World (Columbia, S.C.: University of South Carolina Press, 2001).

Geggus, D.P., and Fiering, N., (eds.), The World of the Haitian Revolution (Bloomington, IN: Indiana University Press, 2009).

Gendron, F., The Gilded Youth of Thermidor, trans. J. Cookson (Montreal: McGillQueen's University Press, 1993).

Geyl, P., Geschiedenis van de Nederlandse Stam, 6 vols. (Amsterdam: Wereldbibliotheek, 1930-1959).

Ghachem, M.W., The Old Regime and the Haitian Revolution (Cambridge: Cambridge University Press, 2012).

Ghachem, M.W. (ed.), 'Slavery and Citizenship in the Age of the Atlantic Revolutions', Historical Reflections/Réflexions historiques 29 (2003).

Girard, P.R., 'Napoléon Bonaparte and the Emancipation Issue in Saint-Domingue, 1799-1803', French Historical Studies 32 (2009), pp. 587-618.

Girard, P.R., The Slaves who defeated Napoleon: Toussaint Louverture and the Haitian War of Independence, 1801-1804 (Tuscaloosa, AL: University of Alabama Press, 2011).

Gobbers, W., Jean-Jacques Rousseau in Holland. Een onderzoek naar de invloed van de mens en het werk (ca. 176o- ca. 1810) (Gent: Secretariaat van de Koninklijke Vlaamse Academie voor Taal- en Letterkunde, 1963).

Godechot, J., Les Révolutions, 1770-1799 (Paris: Presses Universitaires de France, 1963).

Godechot, J., (eds.) Les constitutions de la France depuis 1789 (Paris: Garnier-Flammarion, 1970).

Goldstone, L., 'Constitutionally, Slavery Is Indeed a National Institution', New Republic, September 17, 2015 .

Goodman, D., The Republic of Letters: A Cultural History of the French Enlightenment (Ithaca, N.Y.: Cornell University Press, 1994). 
Gordon, D., Citizens without Sovereignty: Equality and Sociability in French Thought, 1670-1789 (Princeton, N.J.: Princeton University Press, 1994).

Gorman, D., Imperial Citizenship. Empire and the Question of Belonging (Manchester: Manchester University Press, 2007).

Goslinga, W.J. De Rechten van den Mensch en Burger: een overzicht der Nederlandsche geschriften en verklaringen (The Hague: A.J. Oranje, 1936).

Gould, E.H., Among the Powers of the Earth: The American Revolution and the Making of a New World Empire (Cambridge, MA: Harvard University Press, 2012).

Gould, E.H., and Onuf, P.S., (eds.) Empire and Nation: The American Revolution in the Atlantic World (Baltimore, MD:Johns Hopkins University Press, 2005).

Greene, J.P., The Constitutional Origins of the American Revolution (Cambridge: Cambridge University Press, 2010).

Gross, J.-P., Fair Shares for All: Jacobin Egalitarianism in Practice (Cambridge: Cambridge University Press, 1997).

Grossbart, M.A., 'Abraham Bishop: Teacher, Lawyer, Orator, and Politician', in: Morrison (ed.) The Human Tradition in Antebellum America, pp. 1-18.

Gueniffey, G., and Halévi, R., 'Clubs and Popular Societies', in: Furet and Ozouf (eds.) Critical Dictionary, pp. 458-473.

Guénot, H., 'Révolutions de Paris (Les)', in: Soboul, A., (ed.), Dictionnaire historique de la Révolution française (Paris: Presses Universitaires de France, 1989), pp. 907-908.

Guyatt, N., 'De receptie van de Franse Revolutie in Nederland. Contemporaine reactie en geschiedschrijving, Tijdschrift voor Geschiedenis 102 (1989), pp. 451-470.

Guyatt, N., Providence and the Invention of the United States, 1607-1876 (New York: Cambridge University Press, 2007).

Guyatt, N., Bind Us Apart: How Enlightened Americans Invented Racial Segregation (Oxford: Oxford University Press, 2016).

Gusdorf, G., Les Révolutions de France et de l'Amérique. La violence et la sagesse (Paris: Perrin, 1988).

Haan, I. de, Het beginsel van leven en wasdom. De constitutie van de Nederlandse politiek in de negentiende eeuw (Amsterdam: Wereldbibliotheek, 2003).

Haan, I. de, Houd, P. den, and Velde, H. te, (eds.) Een nieuwe staat. Het begin van het Koninkrijk der Nederlanden (Amsterdam: Prometheus, 2014).

Habermas, J., The Structural Transformation of the Public Sphere. An Inquiry into a Category of Bourgeois Society, trans. Burger, T., (Cambridge, MA: Polity Press, 1989 [1962]).

Haitsma Mulier, E.O.G., 'De geschiedschrijving over de patriottentijd en de Bataafse tijd', in: Mijnhardt (ed.) Kantelend geschiedbeeld. Nederlandse historiografie sinds 1945, pp. 206-27, 352-355.

Hale, M.R., "Many who wandered in the darkness": The Contest over American National Identity, 1795-1798', Early American Studies 1 (2003), pp. 127-75. 
Hale, M.R., 'On Their Tiptoes: Political Time and Newspapers during the Advent of the Radicalized French Revolution, circa 1792-1793', Journal of the Early Republic 29 (2009), pp. 191-218.

Halevi, R., Les Loges maçonniques dans la France d'Ancien régime. Aux origines de la sociabilité démocratique (Paris: Armand Colin, 1984).

Hammond, J.C., Slavery, Freedom, and Expansion in the Early American West (Charlottesville, VA: University of Virginia Press, 2007).

Hammond, J.C., 'Slavery, Settlement, and Empire: The Expansion and Growth of Slavery in the Interior of the North American Continent, 1770-1820', Journal of the Early Republic 32 (2012), pp. 175-206.

Hammond, J.C., and Mason, M., (eds.) The Politics of Bondage and Freedom in the New American Nation (Charlottesville, VA: University of Virginia Press, 2011).

Hampsher-Monk, I., Tilmans, K., Vree, F. van, (eds.) History of Concepts: Comparative Perspectives (Amsterdam: Amsterdam University Press, 1998).

Harder, M., 'A Second Terror: The Purges of French Revolutionary Legislators after Thermidor', French Historical Studies 38 (2015), pp. 33-6o.

Harvey, D.A., The French Enlightenment and its Others. The Mandarin, the Savage, and the Invention of the Human Sciences (Basingstoke: Palgrave Macmillan, 2012).

Hartz, L., The Liberal Tradition in America: An Interpretation of American Political Thought since the Revolution (New York: Harcourt, Brace and World, 1955).

Hazareesingh, S., Political Traditions in Modern France (Oxford: Oxford University Press, 1994).

Hazen, C.D., Contemporary American Opinion of the French Revolution (Baltimore, MD: The Johns Hopkins press, 1897).

Heater, D., A Brief History of Citizenship (Edinburgh: Edinburgh University Press, 2004).

Heuer, J.N., The Family and the Nation: Gender and Citizenship in Revolutionary France, 1789-1830 (Ithaca, N.Y.: Cornell University Press, 2005).

Higonnet, P., Sister Republics: The Origin of French and American Republicanism (Cambridge, MA: Harvard University Press, 1988).

Hinderaker, E., Elusive Empires: Constructing Colonialism in the Ohio Valley, 1673-180o (Cambridge: Cambridge University Press, 1997).

Hoffman, R., and Albert, P.J. (eds.) Women in the Age of the American Revolution (Charlottesville, VA: University Press of Virginia, 1989).

Hofstadter, R., The American Political Tradition and the Men who made it (New York: A.A. Knopf, 1948).

Hofstadter, R., The Idea of a Party System. The Rise of Legitimate Opposition in the United States, 1780-1840 (Berkeley, CA: University of California Press, 1972)

Holton, W., Unruly Americans and the Origins of the Constitution (New York, N.Y.: Hill and Wang, 2007). 
Hont, I., Jealousy of Trade: International Competition and the Nation State in Historical Perspective (Cambridge, MA: Belknap Press of Harvard University Press, 2005).

Hont, I., 'The Early Enlightenment Debate on Commerce and Luxury', in: Goldie M., and Wokler, R., (eds.), The Cambridge History of Eighteenth-Century Political Thought (Cambridge: Cambridge University Press, 2006), pp. 379-418.

Horsman, R., The New Republic. The United States of America, 1789-1815 (London: Longman, 2000).

Howe Jr., J.R. 'Republican Thought and the Political Violence of the 179os', American Quarterly 19 (1967), pp. 147-165.

Hoxie, F.E., Hoffman, R., and Albert, P.J., (eds.) Native Americans and the Early Republic (Charlottesville, VA: University of Virginia Press, 1999).

Hulliung, H., Citizens and Citoyens. Republicans and Liberals in America and France (Cambridge, MA: Harvard University Press, 2002).

Hunt, A.N., Haiti's Influence on Antebellum America: Slumbering Volcano in the Caribbean (Baton Rouge, LA: Louisiana State University Press, 1988).

Hunt, L., et al (eds.) 'Robert Roswell Palmer: A Transatlantic Journey of American Liberalism'. Historical Reflections/Réflexions Historiques 37 (2011).

Hunt, L., Politics, Culture, and Class in the French Revolution (Berkeley, CA: University of California Press, 1984).

Huussen Jr., A.H., 'De Staatsregeling van 1798 en het slavernijvraagstuk', in: Moorman van Kappen and Koppens (eds.) De Staatsregeling voor het Bataafsche volk van 1798, pp. $213^{-232 .}$

Innes, J., and Philp, M., (eds.) Re-imagining Democracy in the Age of Revolutions: America, France, Britain, Ireland 1750-1850 (Oxford: Oxford University Press, 2013).

Jackson, M., and Bacon, J., (eds.), African Americans and the Haitian Revolution: Selected Essays and Historical Documents (New York: Routledge, 2010).

Jacobs, E., Oddens, J., and Rutjes, M., (eds.) The Political Culture of the Sister Republics, 1794-1806. France, The Netherlands, Switzerland, and Italy (Amsterdam: Amsterdam University Press, 2015).

Jainchill, A., Reimagining Politics after the Terror: The Republican Origins of French Liberalism (Ithaca, N.Y.: Cornell University Press, 2008).

James, C.L.R., The BlackJacobins. Toussaint L'Ouverture and the San Domingo Revolution (London: Penguin, 2001 [1938]).

Jaume, L., Le discours jacobin et la démocratie (Paris: Fayard, 1989).

Jaume, L., L'Individu effacé ou le paradoxe du libéralisme français (Paris: Fayard, 1997).

Jaume, L., (ed.) Coppet, Creuset de l'esprit libéral: Les idées politiques et constitutionnelles du groupe de Mme de Staël (Aix-en-Provence: Presses Universitaires d'Aix-Marseille, 2000).

Jennings, L.C., 'French Anti-Slavery under the Restoration: the Société de la morale chrétienne', Revue française d'histoire d'outre-mer 81 (1993), pp. 321-331. 
Jennings, L.C., French Anti-Slavery: The Movement for the Abolition of Slavery in France, 1802-1848 (Cambridge: Cambridge University Press, 2000).

Joor, J., De adelaar en het lam (Amsterdam: De Bataafsch Leeuw, 2000).

Jordan, W.D., White Over Black. American Attitudes toward the Negro, 1550-1812 (Chapel Hill, N.C.: The University of North Carolina Press, 1968).

Jorissen, T., 'De Fransche Tijd', in: idem (ed.), Historische bladen (Haarlem: Tjeenk Willink, 1892), pp. 167-273.

Jourdan, A., 'The "Alien Origins" of the French Revolution: American, Scottish, Genevan, and Dutch Influences', Proceedings of the Western Society for French History, 35 (2007), pp. 185-205.

Jourdan, A., 'The Batavian Revolution: Typical French, Typical Dutch or Typical Atlantic?', Dutch Crossing 31 (2007), pp. 271-288.

Jourdan, A., La Révolution batave entre la France et l'Amérique (1795-1806) (Rennes: Presses Universitaires de Rennes, 2008).

Jourdan, A., 'Politieke en culturele transfers in een tijd van revolutie. Nederland 17951805', BMGN/Low Countries Historical Review 124 (2009), pp. 559-579.

Jourdan, A., 'Amsterdam klem tussen staat en volk. Een bedreigde municipaliteit (1795-1798)', in: Nijenhuis, Roelevink, and Sluijter (eds.) De leeuw met de zeven pijlen, pp. $95^{-110 .}$

Jourdan, A., 'The Netherlands in the Constellation of the Eighteenth-Century Western Revolutions', European Review of History: revue européenne d'histoire 18 (2011), pp. 199-225.

Jourdan, A., 'Buitenbeentjes tussen de zusterrepublieken. De Bataafse Republiek in internationaal perspectief', in: Grijzenhout, F., Velema, W., Sas, N. van, (eds.) Het Bataafse experiment. Politiek en cultuur rond 1800 (Nijmegen: Vantilt, 2013), pp. $155^{-184}$.

Jourdan, A., 'Les discours de la terreur à l'époque révolutionnaire (1776-1798): Etude comparative sur une notion ambiguë', French Historical Studies 36 (2013), pp. 51-81.

Kaiser, T.E., and Kley, D.K. van, (eds.) From Deficit to Deluge. The Origins of the French Revolution (Stanford, CA: Stanford University Press, 2011).

Kahan, A., Liberalism in Nineteenth-Century Europe. The Political Culture of Limited Suffrage (Basingstoke: Palgrave Macmillan, 2003).

Kale, S.D., French Salons, High Society and Political Sociability from the Old Regime to the Revolution of 1848 (Baltimore, MD: Johns Hopkins University Press, 2004).

Kalyvas, A., and Katznelson, I., Liberal Beginnings. Making a Republic for the Moderns (Cambridge: Cambridge University Press, 2008).

Kastor, P.J., and Weil, F., (eds.), Empires of the Imagination: Transatlantic Histories of the Louisiana Purchase (Charlottesville, VA: University of Virginia Press, 2009).

Kates, G., The Cercle Social, the Girondins, and the French Revolution (Princeton, N.J.: Princeton University Press, 1985). 
Keller, M., America's Three Regimes. A New Political History (New York: Oxford University Press, 2007).

Kettner, J.H., The Development of American Citizenship, 1608-1870 (Chapel Hill, N.C.: University of North Carolina Press, 1978).

Kidd, C., The Forging of Races: Race and Scripture in the Protestant Atlantic World, 160o2000 (Cambridge: Cambridge University Press, 2006).

Kilroe, E.P., Saint Tammany and the Origin of the Society of Tammany, or Columbian Order in the City of New York (New York, N.Y.: M.B. Brown, 1913).

Klaits, J., and Haltzel, M.H., (eds.), The Global Ramifications of the French Revolution (New York: Cambridge University Press, 1994).

Klein, S.R.E., Patriots republikanisme. Politieke cultuur in Nederland (1766-1787) (Amsterdam: Amsterdam University Press, 1995).

Kley, D. van (ed.) The French Idea of Freedom. The Old Regime and the Declaration of Rights of 1789 (Stanford, CA: Stanford University Press, 1994).

Kloek, J.J., and Mijnhardt, W.W., 180o. Blueprints for a National Community (Basingstoke: Palgrave Macmillan, 2005).

Kloek, J.J., and Tilmans, K., (eds.) Burger. Een geschiedenis van het begrip 'burger' in de Nederlanden van de Middeleeuwen tot de $27^{\text {ste }}$ eeuw (Amsterdam: Amsterdam University Press, 2002).

Klooster, W., Revolutions in the Atlantic World: A Comparative History (New York: New York University Press, 2009).

Koekkoek, R., '“Eene waare en vrije Republiek." Jan Konijnenburg, De republikein en de uitvinding van de moderne republiek', De achttiende eeuw 42 (2010), pp. 236-6o.

Koolhaas-Grosveld, E., 'Over vrouwen in de Bataafs-Franse Tijd', in: Grijzenhout, Van Sas and Velema (eds.) Het Bataafse experiment, pp. 185-213.

Koschnik, A., 'The Democratic Societies of Philadelphia and the Limits of the American Public Sphere, circa 1793-1795, The William and Mary Quarterly $5^{8}$ (2001), pp. $615-636$.

Koschnik, A., "Let a Common Interest Bind Us Together". Associations, Partisanship, and Culture in Philadelphia, 1775-1840 (Charlottesville, VA: University of Virginia Press, 2007).

Koselleck, R., and Schreiner, K. (eds.) Bürgerschaft. Rezeption und Innovation der Begrifflichkeit vom Hohen Mittelalter bis ins 19.Jahrhundert (Stuttgart: Klett-Cotta, 1994).

Koselleck, R., 'Richtlinien für das “Lexikon Politisch-sozialer Begriffe der Neuzeit”, Archiv Für Begriffsgeschichte 11 (1967), pp. 81-99.

Koselleck, R., Vergangene Zukunft. Zur Semantik geschichtlicher Zeiten (Frankfurt am Main: Suhrkamp Verlag, 1979).

Koselleck, R., 'Linguistic Change and the History of Events', Journal of Modern History 61 (1989), pp. 649-666. 
Koselleck, R., Begriffsgeschichten: Studien zur Semantik und Pragmatik der politischen und sozialen Sprache (Frankfurt am Main: Suhrkamp Verlag, 2006).

Kwass, M., Privilege and the Politics of Taxation in Eighteenth-Century France: liberté, égalité, fiscalité (Cambridge: Cambridge University Press, 2000).

Kramer, L.S., 'The French Revolution and the Creation of American Political Culture', in: Klaits and Haltzel (eds.) The Global Ramifications of the French Revolution, pp. 26-54.

Kuiper, J.R., Een revolutie ontrafeld: politiek in Friesland 1795-1798 (Franeker:Van Wijnen, 2002).

Lacorne, D., L'invention de la république. Le modèle américain (Paris: Hachette, 1991).

Landes, J.B., Women and the Public Sphere in the Age of the French Revolution (Ithaca, N.Y.: Cornell University Press, 1988).

Landsman, N.C., From Colonials to Provincials. American Thought and Culture $1680-1760$ (Ithaca, N.Y.: Cornell University Press, 1997).

Langley, L., The Americas in the Age of Revolution, 1750-1850 (New Haven, CT, Yale University Press, 1996).

Leeb, I.L., The Ideological Origins of the Batavian Revolution. History and Politics in the Dutch Republic 1747-180o (The Hague: Nijhoff, 1973).

Lefebvre, G., Les Thermidoriens (Paris: A. Colin, 1937).

Lefebvre, G., Quatre-Vingt-Neuf (Paris: Maison du Livre français, 1939).

Les, L., Van Indië onder de Compagnie tot Indië onder de staat: De koloniale titel in de Staatsregeling van 1798 (Rotterdam: Hartog, 1947).

Lilti, A., The World of the Salons. Sociability and Wordliness in Eighteenth-Century Paris, trans. L.G. Cochrane (Oxford: Oxford University Press, 2015).

Link, E.P., Democratic-Republican Societies, 1790-180o (New York, N.Y.: Columbia University Press, 1942).

Liss, P., Atlantic Empires: The Network of Trade and Revolution, 1713-1826 (Baltimore, MD: Johns Hopkins University Press, 1983).

Livesey, J., Making Democracy in the French Revolution (Cambridge, MA: Harvard University Press, 2001).

Lok, M., “Un oubli total du passé"?: The Political and Social Construction of Silence in Restoration Europe (1813-1830)', History and Memory 26 (2014), pp. 40-75.

Lowance, Jr., M.I., (ed.) A House Divided. The Antebellum Slavery Debates in America, 1776-1865 (Princeton, N.J.: Princeton University Press, 2003).

Luzzatto, S., L'automne de la Révolution. Luttes et cultures politiques dans la France thermidorienne, trans. S.C. Messina (Paris: Editions Honoré Champion, 2001).

Mandell, D.R., Tribe, Race, History. Native Americans in Southern New England, 17801880 (Baltimore, MD: Johns Hopkins University Press, 2010).

Margerison, K., P.L. Roederer: Political Thought and Practice during the French Revolution (Philadelphia, PA: Transactions of the American Philosophical Society, 1983). 
Marshall, D.B., The French Colonial Myth and Constitution-Making in the Fourth Republic (New Haven, CT: Yale University Press, 1973).

Marshall, T.H., Citizenship and Social Class and other Essays (Cambridge: Cambridge University Press, 1950).

Martin, R.W.T., Government by Dissent: Protest, Resistance, and Radical Democratic Thought in the Early American Republic (New York: New York University Press, 2013). Mason, L., 'The Thermidorian Reaction', in: McPhee, P., (ed.) A Companion to The French Revolution (Malden, MA: Wiley-Blackwell, 2012), pp. 313-327.

Mathiez, A., La Révolution française, 3 vols. (Paris: Armand Collin, 1922-1927).

Mathiez, A., La Réaction thermidorienne (Paris: Armand Colin, 1929).

Matthewson, T., 'Abraham Bishop, “The Rights of Black Men," and the American Reaction to the Haitian Revolution', The Journal of Negro History 67 (1982), pp. 148-154.

May, H.F., The Enlightenment in America (New York: Oxford University Press, 1976).

McMahon, D., Enemies of the Enlightenment: The French Counter-Enlightenment and the Making of Modernity (Oxford: Oxford University Press, 2001).

McPhee, P., The French Revolution, 1789-1799 (Oxford: Oxford University Press, 2001).

Meek, R.L., Social Science and the Ignoble Savage (Cambridge: Cambridge University Press, 1976).

Merrick, J., 'Subjects and Citizens in the Remonstrances of the Parlement of Paris in the Eighteenth Century',Journal of the History of Ideas 51 (1990), pp. 453-460.

Michel, P., 'Barbarie, Civilisation, Vandalisme', in: Reichardt and Schmitt (eds.) Handbuch Politisch-Sozialer Grundbegriffe, pp. 7-50.

Mijnhardt, W.W., Tot Heil van 't Menschdom. Culturele genootschappen in Nederland, 1750-1815 (Amsterdam: Rodopi, 1988).

Mijnhardt, W.W. (ed.) Kantelend geschiedbeeld. Nederlandse historiografie sinds 1945 (Utrecht: Spectrum, 1983).

Monnier, R., Républicanisme, patriotisme et Révolution française (Paris, L'Harmattan, 2005).

Monnier, R. (ed.), Citoyen et citoyenneté sous la Révolution française (Paris: Société des études robespierristes, 2006).

Montague, L.L., Haiti and the United States 1714-1938 (Durham, N.C.: Duke University Press, 1940).

Moorman van Kappen, O., and Koppens, E.C. (eds.) De Staatsregeling voor het Bataafsche volk van 1798: Opstellen opgedragen aan de nagedachtenis van Dr. Mr. L. de Gou (Nijmegen: Gerard Noodt Instituut, 2001).

Morgan, E., The Birth of the Republic, 1763-89 (Chicago, IL: University of Chicago Press, 1956).

Morrison, M.A., (ed.) The Human Tradition in Antebellum America (Lanham, MD: Rowman \& Littlefield, 2000). 
Morrison, M.A., and Zook, M.S., (eds.) Revolutionary Currents: Nation Building in the Transatlantic World (Lanham, MD: Rowman \& Littlefield, 2004).

Moyn, S., The Last Utopia: Human Rights in History (Cambridge, MA: Belknap Press of Harvard University Press, 2010).

Moyn, S., 'On the Nonglobalization of Ideas', in: Moyn and Sartori (eds.) Global Intellectual History, pp. 187-204.

Moyn, S., and Sartori, A., (eds.) Global Intellectual History (New York, N.Y.: Columbia University Press, 2013).

Muthu, S., Enlightenment Against Empire (Princeton, N.J.: Princeton University Press, 2003).

Nash, G.B., 'The American Clergy and the French Revolution', The William and Mary Quarterly 22 (1965), pp. 392-412.

Nelson, W.M., 'Colonizing France. Revolutionary Regeneration and the first French Empire', in: Desan, Hunt, and Nelson (eds.) The French Revolution in Global Perspective, pp. $73^{-85}$.

Nesbitt, N., Universal Emancipation: The Haitian Revolution and the Radical Enlightenment (Charlottesville, VA: University of Virginia Press, 2008).

Newman, S.P., Parades and the Politics of the Street: Festive Culture in the Early American Republic (Philadelphia, PA: University of Pennsylvania Press, 1997).

Newman, S.P., 'American Political Culture and the French and Haitian Revolutions. Nathaniel Cutting and the Jeffersonian Republicans', in: Geggus, D.P. (ed.) The Impact of the Haitian Revolution in the Atlantic World (Columbia, S.C.: University of Carolina Press, 2001), pp. 72-89.

Newman, S.P., and Onuf, P.S. (eds.) Paine and Jefferson in the Age of Revolutions (Charlottesville, VA: University of Virginia Press, 2013).

Nicolet, C., L'idée républicaine en France (1789-1924). Essai d'histoire critique (Paris: Gallimard, 1982).

Nicolet, C., 'Citoyenneté française et citoyenneté romaine, essai de mise en perspective', in: Bernstein and Rudelle (eds.) Le modèle républicain, pp. 19-56.

Nietzsche, F., Sämtliche Werke. Kritische Studienausgabe, ed. Collini, G., and Montinari, M., 15 vols. (Munich: Deutscher Taschenbuch Verlag, 1980).

Nijenhuis, I., Roelevink, J., and Sluijter, R., (eds.) De leeuw met de zeven pijlen. Het gewest in het landelijk bestuur (The Hague: ING, 2010).

Oddens, J., Pioniers in schaduwbeeld: het eerste parlement van Nederland 1796-1798 (Nijmegen: Vantilt, 2012).

Oldfield, J.R., Transatlantic Abolitionism in the Age of Revolution. An International History of Anti-Slavery, c. 1787-1820 (Cambridge: Cambridge University Press, 2013).

Onuf, P.S., Jefferson's Empire: The Language of American Nationhood (Charlottesville, VA: University Press of Virginia, 2000). 
Onuf, P.S., Lewis, J.E., and Horn, J., (eds.) The Revolution of 180o: Democracy, Race, and the New Republic (Charlottesville, VA: University Press of Virginia Press, 2002).

Oostindie, G., 'British Capital, Industry and Perseverance' versus Dutch 'Old School'? The Dutch Atlantic and the Takeover of Berbice, Demerara and Essequibo, 17501815, BMGN/Low Countries Historical Review 127 (2012), pp. 28-55.

Oostindie, G., 'Dutch Atlantic Decline during the "Age of Revolutions"', in: Oostindie, G., and Roitman, J.V., (eds.) Dutch Atlantic Connection. Linking Empires, Bridging Borders (Leiden: Brill, 2014), pp. 309-335.

Oostindie, G., and Klooster, W., (eds.), Curaçao in the Age of Revolutions, 1795-180o (Leiden: KITLV Press, 2011).

Ozouf, M., L'École de la France: Essais sur la Révolution, l'utopie et l'enseignement (Paris: Gallimard, 1984).

Ozouf, M., L'homme régénéré: Essais sur la Révolution française (Paris: Gallimard, 1989).

Paasman, A.N., Reinhart: Nederlandse literatuur en slavernij ten tijde van de Verlichting (Leiden: Nijhoff, 1984).

Palmer, R.R., 'Much in little: The Dutch Revolution of 1795', Journal of Modern History 26 (1954), pp. 15-35.

Palmer, R.R., The Age of the Democratic Revolution: A Political History of Europe and America, 1760-180o (Princeton, N.J.: Princeton University Press, 2014 [1959-1964]).

Paquette, G., Imperial Portugal in the Age of Atlantic Revolutions: The Luso-Brazilian World, c. 1770-1850 (Cambridge: Cambridge University Press, 2013).

Pasley, J.L., "The Tyranny of Printers": Newspaper Politics in the Early American Republic (Charlottesville, VA: University Press of Virginia, 2001).

Pasley, J.L., '1800 as a Revolution in Political Culture. Newspapers, Celebrations, Voting, and Democratization in the Early Republic', in: Onuf, Lewis, and Horn (eds.) The Revolution of 1800 , pp. 121-152.

Pasley, J.L., Robertson, A.W., and Waldstreicher, D., (eds.), Beyond the Founders: New Approaches to the Political History of the Early American Republic (Chapel Hill, N.C.: University of North Carolina Press, 2004).

Paulmann, J., 'Interkultureller Transfer zwischen Deutschland und Grossbritannien: Einführung in ein Forschungskonzept', in: Muhs, R., Paulmann, J., and Steinmetz, W., (eds.), Aneignung und Abwehr. Interkultureller Transfer zwischen Deutschland und Grossbritannien im 19. Jahrhundert (Bodenheim: Philo, 1998), pp. 21-43.

Peabody, S., "There are no Slaves in France": The Political Culture of Race and Slavery in the Ancien Régime (New York: Oxford University Press, 1996).

Perron-De Roos, E. du, 'Correspondentie van Dirk van Hogendorp met zijn broeder Gijsbert Karel', Bijdragen tot de Taal-, Land- en Volkenkunde van Nederlandsch-Indië 102 (1943), pp. 125-273.

Peyrard, C., 'Les débats sur le droit d'association et de réunion sous le Directoire', $A n$ nales historiques de la Révolution française 297 (1994), pp. 463-478. 
Philp, M., 'Paine, Rights of Man', in: Clemit, P., (ed.) The Cambridge Companion to British Literature of the French Revolution in the 179os (Cambridge: Cambridge University Press, 2011), pp. 31-46.

Philp, M., 'Revolutionaries in Paris. Paine, Jefferson, and Democracy', in: Newman and Onuf (eds.) Paine and Jefferson in the Age of Revolutions, pp. 137-160.

Philp, M., Reforming Ideas in Britain. Politics and Language in the Shadow of the French Revolution, 1789-1815 (Cambridge: Cambridge University Press, 2014).

Pilbeam, P.M., Republicanism in Nineteenth-Century France, 1814-1870 (Basingstoke: Palgrave Macmillan, 1995).

Piquet, J., L'émancipation des noirs dans la Révolution française: 1789-1795 (Paris: Karthala, 2002).

Pitts, J., 'Empire, Progress, and the "Savage Mind”, in: Levy, J.T., and Young, I.M., (eds.) Colonialism and its Legacies (Lanham, MD: Lexington Books, 2011), pp. 21-52.

Pocock, J.G.A., The Machiavellian Moment: Florentine Political Thought and the Atlantic Republican Tradition (Princeton, N.J.: Princeton University Press, 2003 [1975]).

Pocock, J.G.A., Barbarism and Religion, 6 vols. (Cambridge: Cambridge University Press, 2001-2015).

Pocock, J.G.A., Political Thought and History: Essays on Theory and Method (Cambridge: Cambridge University Press, 2009).

Poell, T., The Democratic Paradox. Dutch Revolutionary Struggles over Democratisation and Centralisation (1780-1813) (Utrecht, Dissertation, 2007).

Polasky, J., Revolutions Without Borders: The Call to Liberty in the Atlantic World (New Haven, CT: Yale University Press, 2015).

Popkin, J.D., 'Les journaux républicains, 1795-1799', Revue d'histoire moderne et contemporaine 31 (1984), pp. 143-157.

Popkin, J.D., 'Print Culture in The Netherlands on the Eve of the Revolution', in: Jacob, M.C., and Mijnhardt, W.W., (eds.) The Dutch Republic in the Eighteenth Century. Decline, Enlightenment, and the Revolution (New York: Cornell University Press, 1992), pp. 273-291.

Popkin, J.D., 'The French Revolution's Other Island', in: Geggus and Fiering (eds.) The World of the Haitian Revolution, pp. 199-222.

Popkin, J.D., Facing Racial Revolution: Eyewitness Accounts of the Haitian Insurrection (Chicago, IL: University of Chicago Press, 2007).

Popkin, J.D., You Are All Free: The Haitian Revolution and the Abolition of Slavery (Cambridge: Cambridge University Press, 2010).

Popkin, J.D., A Concise History of the Haitian Revolution (Malden, MA:Wiley-Blackwell, 2012).

Popkin, J., 'Thermidor, Slavery, and the "Affaire des Colonies”, French Historical Studies 38 (2015), pp. 61-82. 
Potofsky, A., 'The One and the Many: The Two Revolutions Question and the "Consumer-Commercial” Atlantic, 1789 to the present', in: Albertone and De Francesco (eds.), Rethinking the Atlantic World, pp. 17-45.

Prak, M., 'Burghers into Citizens: Urban and National Citizenship in the Netherlands during the Revolutionary Era (c.180o)', in: Hanagan, M., and Tilly, C., (eds.) Extending Citizenship, Reconfiguring States (Lanham, MD: Rowman \& Littlefield 1999), pp. 17-35.

Prak, M., Republikeinse veelheid, democratisch enkelvoud. Sociale verandering in het revolutietijdvak. 's-Hertogenbosch 1770-1820 (Nijmegen: Sun, 1999).

Prak, M., The Dutch Republic in the Seventeenth Century (Cambridge: Cambridge University Press, 2005).

Prak, M., 'The Dutch Republic as a Bourgeois Society', BMGN/The Low Countries Historical Review 125 (2010), pp. 107-138.

Prak, M., Citizens Without Nations. Urban Citizenship in Europe and the World, c. 10oo1789 (Cambridge: Cambridge University Press, 2018).

Prins, W., 'Hume, genoemd. Een inventarisatie van Nederlandstalige reacties op David Hume, 1739-180o' (MA thesis, University of Amsterdam, 2011).

Quinney, V., 'The Problem of Civil Rights for Free Men of Color in the Early French Revolution', French Historical Studies 7 (1972), pp. 544-557.

Ray, T.M., "Not One Cent for Tribute": The Public Addresses and American Popular Reaction to the XYZ Affair, 1798-1799', Journal of the Early Republic 3 (1983), pp. 389-412.

Reichardt, R., and Schmitt, E. (eds.) Handbuch politisch-soziale Grundbegriffe in Frankreich 1680-1820, 8 vols. (Munich: Oldenbourg Verlag, 1988).

Regent, F., Esclavage, métissage, liberté. La Révolution française en Guadeloupe (Paris: Grasset, 2004).

Reitsma, H., 'Lesegesellschaften und Bürgerliche Revolution in Amsterdam', in: Dann, (ed.) Lesegesellschaften und Bürgerliche Emanzipation, pp. 159-180.

Resnick, D.P., 'The Société des Amis des Noirs and the Abolition of Slavery', French Historical Studies 7 (1972), pp. 558-569.

Rétat, P., 'Forme et discours d'un journal révolutionnaire: Les Révolutions de Paris en 1789', in: Labrosse, C., Rétat, P., and Duranton, H. (eds.), L'instrument périodique: La fonction de la presse au XVIIIe siècle (Lyon: Presses Universitaires de Lyon, 1986), pp. 139-178.

Rétat, P., 'Citoyen-sujet, civisme', in: Reichardt, R., and Schmitt, E., (eds.) Handbuch politisch-soziale Grundbegriffe in Frankreich 1680-1820, 8 vols. (Munich: Oldenbourg Verlag, 1988), vol. 8, pp. 75-105.

Riedel, M., 'Bürger, Staatsbürger, Bürgertum', in: Brunner, O., Conze, W., and Koselleck, R., (eds.) Geschichtliche Grundbegriffe. Historisches Lexikon zur politischen-sozialen 
Sprache in Deutschland, 8 vols. (Stuttgart: Klett-Cotta, 1974-1997), vol. 2, pp. $672-725$.

Riesenberg, P., Citizenship in the Western Tradition: Plato to Rousseau (Chapel Hill, N.C.: University of North Carolina Press, 1992).

Robbins, C., The Eighteenth-Century Commonwealthman: Studies in the Transmission, Development, and Circumstance of English Liberal Thought from the Restoration of Charles II until the War with the Thirteen Colonies (Cambridge, MA: Harvard University Press, 1959).

Robertson, A.W., "Look on This Picture ... And on This!" Nationalism, Localism, and Partisan Images of Otherness in the United States, 1787-1820', American Historical Review 106 (2001), pp. 1263-1280.

Roche, D., Le siècle des lumières en province. Académies et académiciens provinciaux, 1689-1789, 2 vols. (Paris: Mouton, 1978).

Roche, D., La France des lumières (Paris: Fayard, 1993).

Rosanvallon, P., Le sacre du citoyen. Histoire intellectuelle du suffrage universel en France (Paris: Gallimard, 1992).

Rosanvallon, P., The Demands of Liberty: Civil Society in France since the Revolution, trans. A. Goldhammer (Cambridge, MA: Harvard University Press, 2007).

Rosenblatt, H., (ed.) Cambridge Companion to Constant (Cambridge: Cambridge University Press, 2008).

Rosendaal, J., Bataven! Nederlandse vluchtelingen in Frankrijk 1787-1795 (Nijmegen: Vantilt, 2003).

Rosenfeld, S., Common Sense. A Political History (Cambridge, MA: Harvard University Press, 2014).

Rothman, A., Slave Country: American Expansion and the Origins of the Deep South (Cambridge, MA: Harvard University Press, 2005).

Rozbicki, M., Culture and Liberty in the Age of the American Revolution (Charlottesville, VA: University of Virginia Press, 2011).

Røge, P., 'l'Économie politique en France et les origines intellectuelles de "la mission civilisatrice" en Afrique', Dix-huitième siècle 44 (2012), pp. 117-130.

Rugemer, E., The Problem of Emancipation: The Caribbean Roots of the American Civil War (Baton Rouge, LA: Louisiana State University Press, 2008).

Rutjes, M., Door gelijkheid gegrepen. Democratie, burgerschap en staat in Nederland 1795-1801 (Nijmegen: Vantilt, 2012).

Sahlins, P., Unnaturally French: Foreign Citizens in the Old Regime and After (Ithaca, N.Y.: Cornell University Press, 2004).

Sas, N.C.F. van, 'The Netherlands, 1750-1813', in: Barker and Burrows (eds.) Press, Politics and the Public Sphere in Europe and North America, 1760-1820, pp. 48-68. 
Sas, N.C.F. van, De metamorfose van Nederland. Van oude orde naar moderniteit, 17501900 (Amsterdam University Press, Amsterdam, 2004).

Sas, N.C.F. van, Bataafse Terreur: De betekenis van 1798 (Nijmegen: Vantilt, 2011).

Sas, N.C.F. van, 'De Republiek voorbij. Over de transitie van republicanisme naar liberalisme', in: Grijzenhout, Velema, and Van Sas (eds.) Het Bataafse experiment, pp. $65^{-100,310-313 . ~}$

Schaffer, A.H., To be an American: David Ramsay and the Making of American Consciousness (Columbia, S.C.: University of South Carolina Press, 1991).

Schama, S., Patriots and Liberators. Revolution in The Netherlands, 1780-1813 (London: Collins, 1977).

Schechter, R., Obstinate Hebrews. Representations of Jews in France, 1715-1815 (Berkeley, CA: University of California Press, 2003).

Schoenbachler, M., 'Republicanism in the Age of Democratic Revolution: The Democratic-Republican Societies of the 179os', Journal of the Early Republic 18 (1998), pp. 237-261.

Schulte Nordholt, J.W., Voorbeeld in de verte. De invloed van de Amerikaanse revolutie in Nederland (Baarn: In den Toren, 1979).

Schutte, G.J., De Nederlandse Patriotten en de koloniën. Een onderzoek naar hun denkbeelden en optreden, 1770-180o (Groningen: Tjeenk Willink, 1974).

Schutte, G.J., 'Zedelijke verplichting en gezonde staatkunde. Denken en doen rondom de slavernij in Nederland en koloniën eind $18^{\mathrm{e}}$ eeuw', in: Documentatieblad werkgroep $18^{e}$ eeuw 41-42 (1979), pp. 101-115.

Schwartz, B., The Great Rights of Mankind: A History of the American Bill of Rights (Lanham, MD: Rowman \& Littlefield, 1992).

Scott, J.W., Only Paradoxes to offer: French Feminists and the Rights of Man (Cambridge, MA: Harvard University Press, 1996).

Scurr, R., 'Social Equality in Pierre-Louis Roederer's Interpretation of the Modern Republic, 1793', History of European Ideas 26 (2000), pp. 105-126.

Scurr, R., 'Pierre-Louis Roederer and the Debate on the Forms of Government in Revolutionary France', Political Studies 52 (2004), pp. 251-268.

Sebastiani, S., The Scottish Enlightenment: Race, Gender, and the Limits of Progress (New York: Palgrave Macmillan, 2013).

Sens, A.P.G., 'Mensaap, heiden, slaaf.' Nederlandse visies op de wereld rond 1800 (The Hague, SDU Uitgevers, 2001).

Sepinwall, A.G., The Abbé Grégoire and the French Revolution. The Making of Modern Universalism (Berkeley, CA: University of California Press, 2005).

Serna P. (ed). Républiques sœurs. Le Directoire et la Révolution atlantique (Rennes: Presses Universitaires de Rennes, 2009).

Serna, P., Francesco, A. de, and Miller, J. (eds.) Republics at War, 1776-1840. Revolutions, Conflicts, and Geopolitics in Europe and the Atlantic World (Basingstoke: Palgrave Macmillan, 2013). 
Sewell, W.H., 'Le Citoyen, la Citoyenne: Activity, Passivity and the French Revolutionary Concept of Citizenship', in: Lucas, C., (ed.) The French Revolution and the Creation of Modern Political Culture, vol. 2: Political Culture of the French Revolution (Oxford: Pergamon Press, 1988), pp. 105-25.

Sewell, W.H., A Rhetoric of Bourgeois Revolution: The Abbé Sieyes and "What Is the Third Estate?" (Durham, N.C.: Duke University Press, 1994).

Sewell, W.H., 'The French Revolution and the Emergence of the Nation Form', in: Morrison and Zook (eds.) Revolutionary Currents: Nation Building in the Transatlantic World, pp. 91-125.

Sewell, W.H., Logics of History. Social Theory and Social Transformations (Chicago, IL: University of Chicago Press, 2005).

Sharp, J.R., American Politics in the Early Republic: The New Nation in Crisis (New Haven, CT: Yale University Press, 1993).

Sheridan, R.B., 'Edwards, Bryan (1743-180o)', in: Oxford Dictionary of National Biography (Oxford: Oxford University Press, 2004), online ed.

Shields, D.S., Civil Tongues and Polite Letters in British America (Chapel Hill, N.C.: The University of North Carolina Press, 1997).

Shovlin, J., The Political Economy of Virtue. Luxury, Patriotism, and the Origins of the French Revolution (Ithaca, N.Y.: Cornell University Press, 2007).

Sinha, M., The Slave's Cause. A History of Abolition (New Haven, CT: Yale University Press, 2017).

Sirks, A.J.B., 'De Constitutie van 1798 en de koloniën', in: Moorman van Kappen and Koppens (eds.) De Staatsregeling voor het Bataafsche volk van 1798, pp. 197-212.

Skinner, Q., Visions of Politics, 3 vols. (Cambridge: Cambridge University Press, 2002).

Slaughter, T.P., The Whiskey Rebellion: Frontier Epilogue to the American Revolution (New York: Oxford University Press, 1986).

Smelser, M., 'The Federalist Period as an Age of Passion', American Quarterly 10 (1958), pp. 391-419.

Smelser, M., 'The Jacobin Phrenzy: The Menace of Monarchy, Plutocracy, and Anglophilia, 1789-1798', The Review of Politics 21 (1959), pp. 239-258.

Smith, J.M., Freedom's Fetters: The Alien and Sedition Laws and American Civil Liberties (Ithaca, N.Y.: Cornell University Press, 1956).

Smith, J.E.H., Nature, Human Nature \& Human Difference. Race in Early Modern Philosophy (Princeton, N.J.: Princeton University Press, 2015).

Smith, R.M. Civic Ideals: Conflicting Visions of Citizenship in U.S. History (New Haven, CT: Yale University Press, 1997).

Smith-Rosenberg, C., This Violent Empire: The Birth of an American National Identity (Chapel Hill, N.C.: University of North Carolina Press, 2010).

Soboul, A., Histoire de la Révolution française, 2 vols. (Paris: Éditions sociales, 1962).

Sonenscher, M., Before the Deluge: Public Debt, Inequality and the Intellectual Origins of the French Revolution (Princeton, N.J.: Princeton University Press, 2007). 
Spieler, M.F., 'The Legal Structure of Colonial Rule during the French Revolution', William and Mary Quarterly 66 (2009), pp. 365-408.

Spieler, M.F., Empire and Underworld: Captivity in French Guiana (Cambridge, MA: Harvard University Press, 2011).

Stouten, J., Willem Anthonie Ockerse (1760-1826). Leven en werk. Het bewogen leven van een verlicht 'Bataafs' politicus, letterkundige, predikant en wijsgeer en zijn veelzijdig oeuvre op de overgang van de achttiende naar de negentiende eeuw (Amsterdam: APA-Holland Universiteits Pers, 1982).

Stuurman, S. The Invention of Humanity. Equality and Cultural Difference in World History (Cambridge, MA: Harvard University Press, 2017).

Tackett, T., The Coming of the Terror in the French Revolution (Cambridge, MA: Harvard University Press, 2015).

Tannenbaum, F., Slave and Citizen: The Negro in the Americas (New York: Vintage, 1964).

Taylor, A., The Divided Ground: Indians, Settlers, and the Northern Borderland of the American Revolution (New York: A.A. Knopf, 2006).

Troper, M., Terminer la Révolution. La Constitution de 1795 (Paris: Fayard, 2006).

Trouillot, M., Silencing the Past. Power and the Production of History (Boston, MA: Beacon Press, 1995).

Tunstall, K.E., (ed.) Self-Evident Truths? Human Rights and the Enlightenment (New York: Bloomsbury, 2012).

Van Horn Melton, J., The Rise of the Public in Enlightenment Europe (Cambridge University Press, 2001).

Velde, H. te, 'Political Transfer. An Introduction', European Review of History: Revue européenne d'histoire 2 (2005), pp. 205-221.

Velema, W.R.E., 'Republican readings of Montesquieu: The Spirit of The Laws in the Dutch republic', History of Political Thought 18 (1997), pp. 43-63.

Velema, W.R.E., Republicans: Essays on Eighteenth-Century Dutch Political Thought (Leiden: Brill, 2007).

Velema, W.R.E., 'Republikeinse democratie. De politieke wereld van de Bataafse Revolutie, 1795-1798', in: Grijzenhout, Velema, and Van Sas (eds.) Het Bataafse experiment, pp. 27-63.

Vincent, B., The Transatlantic Republic. Thomas Paine and the Age of Revolutions (Amsterdam: Rodopi, 2005).

Vincent, K.S., Benjamin Constant and the Birth of French Liberalism (New York: Palgrave-Macmillan, 2011).

Vovelle, M., (ed.), Le tournant de l'an III. Réaction et Terreur blanche dans la France révolutionnaire (Paris: Éditions du CTHS, 1997).

Vries, M. de, Beschaven! Letterkundige genootschappen in Nederland 1750-180o (Nijmegen: Vantilt, 2002). 
Vries, J. de, 'The Dutch Atlantic Economies', in: Coclanis, P.A., (ed.) The Atlantic Economy during the Seventeenth and Eighteenth Centuries: Organization, Operation, Practise and Personnel (Columbia, S.C.: University of South Carolina Press, 2005), 1-29.

Vuyk, S., 'De republikein van Jan Konijnenburg (februari 1795-augustus 1797)', in: Wissing, P. van, (ed.) Stookschriften: pers en politiek tussen 1780 en 1800 (Nijmegen: Vantilt, 2008), pp. 217-229.

Wal, E. Van der., 'Geen natie van atheïsten. Pieter Paulus (1753-1796) over godsdienst en mensenrechten', Jaarboek van de Maatschappij der Nederlandse Letterkunde te Leiden, 1995-1996 (Leiden: Brill, 1997), pp. 45-62.

Wallace, A.F.C., Jefferson and the Indians: The Tragic Fate of the First Americans (Cambridge, MA: Belknap Press of Harvard University Press, 1999).

Waldinger, R., Dawson, P., and Woloch, I., (eds.) The French Revolution and the Meaning of Citizenship (Westport, CT: Greenwood Press, 1993).

Waldstreicher, D., In the Midst of Perpetual Fetes: The Making of American Nationalism, $1776-1820$ (Chapel Hill, N.C.: University of North Carolina Press, 1997).

Waldstreicher, D., Slavery's Constitution. From Revolution to Ratification (New York: Hill and Wang, 2009).

Waldstreicher, D., 'How the Constitution Was Indeed Pro-Slavery', The Atlantic, September 19, 2015.

Wanquet, C., La France et la première abolition de l'esclavage, 1794-1802: Le cas des colonies orientales, Île de France (Maurice) et La Réunion (Paris: Karthala, 1998).

Wanquet, C., 'Un Réquisitoire contre l'abolition de l'esclavage: Les Égarements du nigrophilisme de Louis Narcisse Baudry Deslozières (Mars 1802)', in: Bénot and Dorigny (eds.) Rétablissement de l'esclavage dans les colonies françaises, pp. 29-50.

Warren, C., and Ames, N., Jacobin and Junto; Or, Early American Politics as viewed in the Diary of Dr. Nathaniel Ames, 1758-1822 (Cambridge, MA: Harvard University Press, 1931).

Weber, E., Peasants into Frenchmen. The Modernization of Rural France, 1870-1914 (Stanford, CA: Stanford University Press, 1976).

Wells, C.C. Law and Citizenship in Early Modern France (Baltimore, MD: Johns Hopkins University Press, 1995).

Whatmore, R., Republicanism and the French Revolution. An Intellectual History of JeanBaptiste Say's Political Economy (Oxford: Oxford University Press, 200o).

Whatmore R., and Livesey, J., 'Etienne Clavière, Jacques-Pierre Brissot, et les fondations intellectuelles de la politique des Girondins, Annales historiques de la Révolution française 3 (2000), pp. 1-26.

Whelan, F.G. Enlightenment Political Thought and Non-Western Societies: Sultans and Savages (New York: Routledge, 2009).

White, A., Encountering Revolution. Haiti and the Making of the Early Republic (Baltimore, MD: Johns Hopkins University Press, 2010). 
White, R., The Middle Ground: Indians, Empires and Republics in the Great Lakes Region, 1650-1815 (Cambridge: Cambridge University Press, 1991).

Wilder, G., The French Imperial Nation-State. Negritude and Colonial Humanism between the Two World Wars (Chicago, IL: Chicago University Press, 2005).

Wilentz, S., The Rise of American Democracy: Jefferson to Lincoln (New York, N.Y.: Norton, 2006).

Wilentz, S., 'Constitutionally, Slavery Is No National Institution', New York Times, September 16, 2015.

Williams, D., Condorcet and Modernity (Cambridge: Cambridge University Press, 2004). Wit, C.H.E. de, De strijd tussen aristocratie en democratie in Nederland, 1780-1848 (Heerlen: Winants, 1965).

Wolloch, n., "Facts, or Conjectures": Antoine-Yves Goguet's Historiography',Journal of the History of Ideas 68 (2007), pp. 429-449.

Woloch, I., Jacobin Legacy: The Democratic Movement under the Directory (Princeton, N.J.: Princeton University Press, 1970).

Woloch, I., The New Regime. Transformations of the French Civic Order, 1789-1820s (New York, N.Y.: Norton, 1994).

Wood, G.S., The Creation of the American Republic, $1776-1787$ (Chapel Hill, N.C.: University of North Carolina Press, 1969).

Wood, G.S., The Radicalism of the American Revolution (New York: Vintage Books, 1991).

Wood, G.S., Empire of Liberty: A History of the Early Republic, 1789-1815 (Oxford: Oxford University Press, 2009).

Wokler, R., 'Anthropology and Conjectural History in the Enlightenment', in: Fox, C., Porter, R., and Wokler, R., (eds.), Inventing Human Science. Eighteenth-Century Domains (Berkeley, CA: University of California Press, 1995), pp. 31-52.

Woronoff, D., La République bourgeoise de Thermidor à Brumaire, 1794-1799 (Paris: Seuil, 1972).

Wright, J.K., A Classical Republican in Eighteenth-Century France. The Political Thought of Mably (Stanford, CA: Stanford University Press, 1997).

Yirush, C., Settlers, Liberty, and Empire: The Roots of Early American Political Theory, 1675-1775 (Cambridge: Cambridge University Press, 2011).

Young, A.F., The Democratic Republicans of New York: The Origins, 1763-1797 (Chapel Hill, N.C.: University of North Carolina Press, 1967).

Young, A.F., 'Common Sense and the Rights of Man in America. The Celebration and Damnation of Thomas Paine', in: Gavroglu, K., Stachel, J., Wartofsky, M.W., (eds.) Science, Mind, and Art (Dordrecht: Kluwer, 1995), pp. 411-439.

Young, J.R., (ed.) Proslavery and Sectional Thought in the Early South, 1740-1829: An Anthology (Columbia, S.C.: University of South Carolina Press, 2006). 
Zanten, J. van, Schielijk, Winzucht, Zwaarhoofd en Bedaard. Politieke discussie en oppositievorming, 1813-1840 (Amsterdam: Wereldbibliotheek, 2004).

Ziesche, P., Cosmopolitan Patriots. Americans in Paris in the Age of Revolution (Charlottesville, VA: University of Virginia Press, 2010).

Zuckerman, M., 'The Power of Blackness: Thomas Jefferson and the Revolution in St. Domingue', in: idem, Almost Chosen People. Oblique Biographies in the American Grain (Berkeley, CA: University of California Press, 1993), pp. 175-219. 


\section{Index}

Adams, John $\quad 36,44,102,170,175,188$

Adams, John Quincy 28n4, 175

Adet, Pierre-August 129

Affaires de l'Angleterre et de l'Amérique 38

Albany Register 195

Alien and Sedition Acts 189, 195

American Minerva $\quad$ 184-185, 187, 190

américanistes 29n8, 37, 42

Apollo; or, Chestertown Spy $\quad$ 175-176

Arcy, Gouy d' 74

Arendt, Hannah 16

Argus (Boston, MA) 51n74, 62n12, 102, 180, $18 \mathrm{in} 42$

Argus (New York, N.Y.) 195-196

Armitage, David 32

Aurora General Advertiser $\quad 181$

Bache, Benjamin Franklin 181

Baczko, Bronisław 133, 134n6, 141, 149

Baecque, Antoine de 90

Barbeau du Barran, Joseph-Nicolas 148-149

Barnave, Antoine 74

Barruel, Augustin $\quad$ 192-193

Baudin des Ardennes,

Pierre-Charles-Louis $\quad 15^{1-152}$

Baudry Des Lozières, Louis-Narcisse 130

Belknap, Jeremy 119

Belley, Jean-Baptiste 105

Benezet, Anthony 72

Bénot, Yves 129

Bijdragen tot het menschelijk geluk 88, 109

Bishop, Abraham 62, 103

Bloch, Ruth 177

Blumenbach, Friedrich 86

Boissy d'Anglas, François-Antoine $123-126$, 149, 158-162, 164-165, 167, 216-218

Bonnemain, Antoine-Jean-Thomas $\quad 62$, 95-96

Bosch, Bernardus $\quad 29-30,31,40,88,109,220$, 235-237, 246

Bourdon, François Louis $\quad 147,157$

Bradburn, Douglas $\quad 43,188$

Brissot, Jacques-Pierre $37,47,51,68,75,79$,

91, 93-94, 103, 106, 139

Bruix, Étienne Eustache 129
Buffon, Georges-Louis Leclerc 86

Bureau de Pusy, Jean-Xavier 28-29

Burger politieke blixem 235

Burke, Edmund $\quad 27,30,76-77,123,169$

Burlamaqui, Jean-Jacques 50

Cabanis, Pierre-Jean-George $\quad$ 153-154, 158

Cambacérès, Jean-Jacques 166

Capellen tot den Pol, Joan Derk van der $35^{-36}$

Charpentier-Cossigny, Joseph-François 129

Chastellux, François Jean de Beauvoir, marquis de 37

Chateaubriand, René 131

Cicero 50, 202

citizenship

active and passive $\quad 54$

bad citizen / good citizen $\quad$ 133, 141-145

in Batavian constitution of $1798 \quad 232$

and civilization see civilization and citizenship

and education $114,117,166-167$

and empire $\quad 63-68,74-76,105^{-106}$, 110-111, 118, 124

exclusion from $12,5^{2-5} 6$

French revolutionary citizenship, 1792-1794 136-141

revolutionary redefinition of 26

and rights 53

scope of $13,81,90,158,164$

and women $\quad 52,232 n 92$

City Gazette (Charleston, S.C.) 73

Civilization

and citizenship $\quad 88,90,107,115,118$

distinction civilized and uncivilized $\quad 12$, $81-83,121,130$

Enlightenment language of $82-91$, $115^{-116}$

in relation to race $85-87,241$

and regeneration $59,62,72-73,75$,

88-90, 95-96

Clarkson, Thomas $\quad 92$

Clermont-Tonnerre, Stanislas 42

Cleves, Rachel Hope 193

Cobbett, William $\quad$ 192-193 
Columbian Centinel $\quad 99,184,187$

Columbian Herald or the Southern Star 103

commercial society $3,134,156$

Condorcet, Marie-Jean-Antoine Nicolas de

Caritat, marquis de $\quad 37-40,44-47$,

$5^{0-51,54-55,68, ~ 82, ~ 86, ~ 94, ~ 96, ~ 106, ~ 109, ~}$

$115,123,127,240$

Condorcet, Sophie de 39

Connecticut Journal 101

Constant, Benjamin $\quad 150 n 47,164$

Constitution

as bulwark of democratic citizenship 30 , 31-34, 47-48

American state constitutions $\quad 28,34-42$

American constitution $\quad 43,71,98,194$, 196-197

Batavian constitution $\quad 213-219,228,232$, 234

and empire $\quad 60,67,74,81,94-95,106$, 110-115, 123-126

French constitution of $1791 \quad 55$

French constitution of $1793 \quad 106,158-159$, 208, 227-228

French constitution of $1795 \quad 106,123,149$, $152,158,160,162-163,229$

Thomas Paine's definition of $\quad 47-48$

convergence; of citizenship ideals $\quad 4,26-31$

Cooper, Thomas 197

Costa, Isaac da 246

Cotlar, Seth 16

Cour Grandmaison, Olivier Le 54

Cras, Hendrik Constantijn $\quad$ 109, 218

Crassous, Joseph Augustin $\quad 146$

Creuzé-Latouche, Jacques Antoine 165

Crèvecoeur, John Hector St. John de 40

Curran, Andrew $\quad$ 130, 131

Cutting, Nathaniel $\quad 65^{-66,100-101}$

Daniel, Marcus 195

Danton, George $\quad$ 103, 139

Daunou, Pierre-Claude-François $\quad$ 166-167

De democraten 201, 215, 223, 225-227, 229-230

De heer Janus-Janus zoon 235

Declaration of the Rights of Man and Citizen

American state declarations $\quad 32-34$

Dutch Declaration (1795) 50

French Declaration (1789) 11, 33

Decrès, Denis 131
Defermon des Chapelières, Joseph-Jacques $\quad 161$

Delacroix, Charles-François 232

Democratic-Republican Societies

(American) 13, 179-188

Desmoulins, Camille $\quad 55,139$

Dew, Thomas Roderick 244

Diderot, Dénis 41

Dorigny, Marcel 95

Dubois, Laurent 85

Dufay, Louis 105

Dumont-Pigalle, Pierre Alexandre 210

Dumouriez, Charles-François 207, 211

Dunlap's American Daily Advertiser $\quad 27,92$

Dupont de Nemours, Pierre Samuel 37,44 , 162-164

Dutch Patriot Movement 14, 22 and the American Revolution $\quad 36-37$

Dwight, Theodore 103

Dwight, Timothy $\quad$ 193-194

Echeverria, Durand 37

Edelstein, Dan $\quad$ 18, 32, 84

Edwards, Bryan $\quad$ 120-122, 242-243

empire

and citizenship see citizenship and empire

constitutional unity of $\quad 11,67-68$

Dutch colonial empire $\quad 107-108$

French colonial empire $\quad 63-64$

Faction

critique of $98,107,136,149,15^{-1} 5^{2}, 15^{6}$, $168,184,221-222$

and popular societies $\quad 151,168,184,221$, 227, 247

Federal Gazette and Philadelphia Daily Advertiser 28

Federal Gazette \& Baltimore Daily Advertiser 123

Federal Orrery $\quad 170-171,183,185$, 187

Federalists (American) criticizing democratic-republican societies $13,24,180,183-187$ and anti-Jacobinism 190-193

Floh, Hendrik Jacob $\quad 63 n 14,111-113$

Franco-American Naval War

('Quasi-War') 24 
Franklin, Benjamin $\quad 28 \mathrm{n} 4,36,38,42,71 \mathrm{n} 40$, 191

Franq van Berkhey, Johannes le $\quad 236-237$

free coloured people $\quad 5^{8}$

and citizenship $\quad 62,75^{-76}$

invoking the Declaration of Rights 11, $67-68$

American newspapers on 73

Freneau, Philip 102

Fréron, Louis-Marie-Stanislas $\quad$ 133, 145

Friesche Courant 233

Frossard, Benjamin $\quad 21,88$

Gainot, Bernard $15^{2}$

Garran-Coulon, Jean-Philippe $\quad$ 92-95

Gauchet, Marcel 32

Gazette de Leyde 35

Gazette of the United States $\quad 28,44,186,194$

Geggus, David $5^{8}$

Genet, Edmond-Charles $\quad$ 178-179, 181

Gobineau, Arthur comte de 241

Godechot, Jacques 14-15

Gogel, Alexander $\quad 221,238$

Gogues, Antoine-Yves $\quad 82-83$

Gouges, Olympe de $\quad 96-97$

's-Gravenhaagse courant 206

Greenleaf, Thomas 177

Grégoire, Henri $\quad 55,68,75-76,94,96-97$, 106, 109, 126-127, 243

Gueniffey, Patrice 138

Guizot, François 248

Guyatt, Nicholas 72

Hahn, Jacob George Hieronimus $\quad$ 50, 113, 228 Haitian Revolution; representations of $\quad 8-9$ Halévi, Ran 138

Hamelsveld, IJsbrand van $\quad$ 221-222, 224, 226

Hamilton, Alexander $\quad 43,7 \mathrm{ln} 40,98,179,182$

Hammond, John Craig 69

Hébert, Jacques 140

Higonnet, Patrice 139

Historiesch schouwtooneel van 's waerelds lotgevallen 78

Hoen, Pieter 't 230

Hogendorp, Dirk van 245

Hogendorp, Gijsbert-Karel van $\quad$ 213, 245

Hooff, Jan van $\quad 210-211,224,226$

Huber, Johan $\quad$ 203, 228
Hunt, Lynn $\quad 32,60$

Hutcheson, Francis 36

Independent Chronicle 196, 198

Jacobin; Jacobin Club 51,138-139

Thermidorian efforts to detach citizens from the Jacobin Clubs 146-154 associated with (American) democraticrepublican societies $\quad 183-187$

associated with atheism and anarchy 190-191

Jefferson, Thomas $39,42,44 n 49,46,49,65$, $72,87,98,100-102,104,182,197,199,249$

Josef II, Emperor 205

Jourdan, Annie $\quad$ 17, 204

Kahan, Alan 245

Kemp, François Adriaan van der 36

Kluit, Adriaan $\quad 42,78-80,101,211$

Kock, Johan de 210-211

Konijnenburg, Jan $\quad 51,88,109,117$

labour

division of 3

labour and industry as underpinnings of citizenship $134,155^{-158,163}$

Lacroix, Charles 166

Lacrosse, Jean-Baptiste Raymond de 131

Lafayette, Marie-Joseph Paul Yves Roch

Gilbert du Motier, marquis de 30,49 ,

$68,212,241$

Lally-Tollendal, Trophime Gérard 42

Lammens, Adriaan François 246

Lanjuinais, Jean-Denis $\quad 161,165,167$

Lanthenas, François 144

Leclerc, Charles 128

Lee, Henry 186

Leerzame praat-al, de 29, 109

Lezay-Marnésia, Adrien 164

Liebeherr, Bogilaus von $\quad 110-111,114$

Lindet, Jean-Baptiste Robert $\quad$ 132-133, 135, 141-145, 154-157

Locke, John $\quad 21,34,49-50$

Lolme, Jean Louis de $\quad 42,44$

Loosjes, Adriaan $\quad 41$

Louverture, Toussaint $\quad 122,127-128$

Luzzatto, Sergio 133 
Mably, Gabriel Bonnot de $\quad 37,41$

Madison, James 44n49, 98, 102, 172n10, 182

Malesherbes, Chrétien de 42

Mandrillon, Joseph 41

Manen, Jacob van $\quad 227$

Marat, Jean-Paul 103, 139, 156, 198, 218, 226

Marck, Frederick Adolph van der $117-118$

Mazzei, Philip $\quad 37,39-40$

Meerman, Johan $\quad$ 212-213

Midderich, Hendrik 47

Miller, Samuel $\quad 176$

Mills, Jean-Baptiste 105

Mirabeau, Honoré-Gabriel Riqueti, comte de $39-40,67-68$

Mist, Jacob Uytenhage de 111

Moens, Petronella $\quad 30 n 10,109$

Montesquieu 21, 50, 51, 229, 239

Moreau de Saint-Méry, Médéric-Louis-Élie 87

Morse, Jedidiah 193

Mounier, Jean-Joseph $\quad 42,51$

Moyn, Samuel 61

Napoleon Bonaparte $\quad 57,127-130,154$ $250-251$

nation

and empire $\quad 61,66,94-95$

national citizenship $\quad 26-27,44-45,144$, 249-250

nationalization $171,188,194-200,204$, 227-231

National Gazette $\quad$ 100-103, 181

New-Hampshire Gazette 101

New-JerseyJournal 100

New-York Daily Gazette 73

New-YorkJournal 177

Nieuwe bijdragen tot het menschelijk geluk 115

Ockerse, Willem Anthonie 201, 208-209, 214-216, 218, 221, 223, 228-230, 232, 238-239, 244

Oddens, Joris 211

Ogé, Vincent $\quad 68,75$

Ozouf, Mona 90
Paape, Gerrit 203

Paine Jr., Robert Treat $\quad 169-171,183,187-188$, 193

Paine, Thomas 4 , 21, 27, 30, 42, 45-51, 62, 102, 144, 163-164, 190, 198, 217-218

Palm, Johannes van der $\quad 226$

Palmer, Robert R. 14-15, 204

participation (political participation)

ideals of 13,148

in popular societies

critique of 24

Paulus, Pieter $\quad 49-50,78,80,101,109,208,211$

Pitts, Jennifer 82

Playfair, William 192

Polasky, Janet 17

Politique hollandaise 35

Polverel, Étienne $\quad 79-80,103,106$

Popkin, Jeremy 91

popular societies

American popular societies see democratic-republican societies

in the Batavian Revolution 13

and faction $151-152,156,184-185$, 220-222

in France see Jacobin

associated with the Terror 13

Porcupine's Gazette 192

Post, Elisabeth Maria 109

Price, Richard $\quad 21,34-36,50$

Priestly, Joseph 21, 36, 198

Racism, race 85

Raimond, Julien $\quad 68,106$

Ramsay, David 26, 30, 175

Randolph, Edmund 43

Raynal, Guillaume-Thomas François $\quad$ 21, 51, 239, 245

Reinhard, Charles-Frédéric $\quad 90$

representative democracy

Republicanism 2, 37

Republicans (American) 24

relation to democratic-republican societies 182

republikein, de (journal) 26, 30

Reubell, Jean-François $\quad$ 147, 152

Révellière-Lépeaux, Louis Marie de la $\quad 152$, 161

Révolutions de Paris $\quad 26,30$ 
Rice, David 103

rights

and citizenship 53

logic of $11,20,60-63,73,89,117,241$

political rights $163-165,233$

rights declarations as an Atlantic

revolutionary phenomenon $\quad 31-34$, 38-39

Robertson, William $\quad 82,244$

Robespierre, Maximilien $\quad 10,16,55,89,103$, $106,132-133,140,142-145,147,155,158$, 162, 176, 189, 191, 196, 198, 202, 215, $217-218,226,236$

Robison, John 192-193

Rochefoucauld, Louis-Alexandre Duc de la 38,53

Roederer, Pierre-Louis $\quad$ 148, 150, 155-158, 163

Rosanvallon, Pierre 245

Rosendaal, Joost 205

Rousseau, Jean-Jacques $\quad 22,34,36,40,49,51$, $83,155,220,239,245$

Rush, Benjamin 72

Saige, Guillaume-Joseph $\quad 41$

Saint-Domingue $\quad 63-64$

as point of reference $9,13,59-60,62$, 73-74, 76, 79, 94, 102, 112-113, 116, 118, 120, 241-246

Salem Gazette 194

Sas, Niek van 204

Schimmelpenninck, Rutger-Jan $\quad 36-37,40$, 112-113

Schutte, G. $\quad 115^{-116,118}$

Sepinwall, Alyssa Goldstein $\quad 89$

Sharp, James R. 99

Sieyès, Emmanuel Joseph $\quad$ 51, 154-155, 206 slavery

in the Dutch empire 108-109

in the French empire $\quad 66-67$

French abolition decree of $11,16,59$, 105-106

in the USA $\quad 70-71$

Smith, Adam 82

Smith, Samuel Stanhope $\quad 72,83-84$

Smyth, Alexander $\quad 242-243$

Société des Amis des Noirs $\quad 60,62,68,73,75$, 79, 81, 91-92, 95-97, 112, 121, 126, 131

Sonthonax, Léger-Félicité $\quad 59,79-80,103,106$ Spiegel, Laurens Pieter van der 42
Spoors, Jacob 234

St. Louis Enquirer 243

Staël, Madame de $\quad$ 150-151

Stevens, John 44

Swildens, Jan Henrik 218-219

Tallien, Jean-Lambert $\quad$ 133, 143-145, 157-158

Tammany Society $\quad 5 \mathbf{1}^{-52,177,198}$

Taylor, John $\quad 242$

Terror 140-141

representations of $\quad 8-9,142,149-15^{0}$

and American Federalists $\quad 171-173$, $183-184,189-192$

and Batavian revolutionaries 201, 203, 211, 215-216, 218-219, 225, 227-228, 230 and French Thermidorians $\quad 132,135$, $142-143,145,151,160$

Thermidor 10, 133

Thermidorian politicians $\quad 12,133,135$, 146-149, 244

Atlantic Thermidor $\quad 10-11,14$

Thibaudeau, Antoine Claire 146

Thionville, Merlin de $\quad$ 147-148

Thuriot, Jacques-Alexis 147

Tucker, St. George $\quad$ 118-120

Tula 108

Turgot, Anne-Robert-Jacques 82

Vincent, Bernard 46

Vitringa, Herman Hendrik $\quad$ 37, 62-63, 228

Voltaire 22, 239

Vreede, Pieter 112, 114, 220, 224, 232

Vries, Jan de 108

Washington, George $\quad 30,45,65,170,175$, $177-178,183,186,198,202$

Weber, Eugen 245

Webster, Noah $\quad 174-175,184-185,187,193$

Whiskey Rebellion $\quad 24,183^{-187}$

Willcocks, William $\quad 185,187$

William V of Orange, Stadholder 35, 37, 205

Wiselius, Samuel 110-111, 114, 210, 221, 234, 240, 244

Wolff, Betje 109

Woloch, Isser 152

Wortman, Tunis $\quad$ 197-198

XYZ Affair $\quad 24,188-189$ 